\author{
В.Е. Дьяков
}

\title{
ЦЕНТРОБЕЖНАЯ ФИЛЬТРАЦИЯ РАСПЛАВЛЕННОГО ОЛОВА И СВИНЦА
}

Монография 
УДК 66-931

ББК 34.33

Д931

\section{Рецензенты:}

Копылов Николай Иванович - доктор технических наук, ведущий научный сотрудник, ФГБУН «Института химии твёрдого тела и механохимии СО РАН;

Олейникова Наталья Васильевна - доктор технических наук, профессор кафедры «Металлургия цветных металлов» Института цветных металлов и материаловедения, ФГАОУ ВО «Сибирский федеральный университет»;

Чекушина Владимир Семенович - профессор кафедры ЭЖД КрИЖТ, ФБГОУ ВО «Иркутский государственный университет путей сообщения».

Д931

Дьяков В.Е.

Центробежная фильтрация расплавленного олова и свинца: монография. - М.: Издательский дом Академии Естествознания, 2019. - $140 \mathrm{c}$.

\section{ISBN 978-5-91327-574-5}

DOI 10.17513/np.347

Монография посвящена обобщению публикаций исследовательских работ и изобретений по разработке центробежной фильтрации при рафинировании расплавов олова и свинца.

Исследованием кинетики центробежной фильтрации олова от железа и мышьяка и излагается оценка влияния соотношения железа к мышьяку на выход олова в отходы. Приведены показатели освоения центробежной фильтрации олова погружаемым фильтром с оценкой скорости циркуляции расплавом через фильтр для экстракции твердых примесей из расплава. Приводятся результаты сравнения вариантов удаления остаточного мышьяка в соединениях с алюминием, хромом, железом и марганцем и обоснованы оптимальные условия рафинирования с марганцем. Исследованы физико-химические свойства фаз оптимальной связи мышьяка с марганцем и их поведение в центробежном поле, определено влияние состава металла на толщину пленки олова на поверхности кристаллов фильтростатков. Выявлены возможности отстойных фильтров и оценено оптимальное окисление поверхностных пленок кристаллов марганец мышьяковой пены для фильтрации.

Приведенные результаты испытания рафинирования свинца от меди центробежной фильтрацией показали снижение выход свинца в отходы снижается в 2,4 раза. Показаны возможности модернизации погружаемых фильтров для непрерывного обезмеживания свинца и щелочного рафинирования от мышьяка. Опытными испытаниями показано, что центробежная фильтрация позволяет в 2,6 раза повысить степень обогащения серебристых шликеров и в 3,2 раза висмутовых шликеров и повысить экономичность их переработки до продукции.

140 с., рис. 69, табл. 51, библ. 124.

Ключевые слова: олово, свинец, рафинирование, расплавы, фильтрация, погружаемый фильтр.

ISBN 978-5-91327-574-5

(C) Дьяков В.Е., 2019

(c) ИД «Академия Естествознания»

(c) АНО «Академия Естествознания» 


\section{ПРЕДИСДОВИЕ}

В отечественной цветной металлургии в последние десятилетия разработаны, испытаны и освоены в промышленную практику ряд новых перспективных металлургических процессов, как, например, обжиг в кипящем слое (КС); плавка в жидкой ванне (ПЖВ, плавка Ванюкова); процесс КИВЦЭТ-ЦС.

К новым перспективным процессам можно отнести работы по разработке и внедрению в металлургическую практику центробежную фильтрацию расплавленных металлов.

Настоящая монография посвящена обобщению публикаций результатов исследовательских работ и изобретений по разработке и освоению рафинирования расплавленных металлов от твердых примесей центробежной фильтрацией. Разработка технологии рафинирования фильтрацией проведена под руководством С.Н. Сутурина, начальником опытного цеха Новосибирского оловянного комбината. Серию промышленных аппаратов центробежной фильтрации разработал конструктор, научный сотрудник СКБ ГИТ СО РАН А.В. Долгов. Новосибирский машиностроительный завод «Труд» выполнил проект ПАФВС650 и изготовил серию аппаратов на экспорт.

Большой вклад в освоении центробежной фильтрации олова внесли зам начальники цехов А.Е. Семенов, А.П. Дугельный, а в последствии главный инженер НОК. Координация работ осуществлялась руководством лабораторий головного института ЦНИИолова. Значительный вклад в разработке рафинирования свинца центробежной фильтрацией внесли сотрудники института Гидроцветмет МЦМ и УКСЦК.

Научно-исследовательские работы осуществлялись научным сопровождением лабораторий директора института ИНХ СО РАН, академика А.В. Николаева. Исследованиям оказывалась неоценимая методическая и инструментальная помощь сотрудников института ИХТТИМС СО РАН, института катализа СО РАН.

Разработанная технология центробежной фильтрации расплавленных металлов от нерастворимых примесей погружаемым фильтром освоена в металлургии олова. В целом комплекс технологий отмечен Государственной премией 1985 г.

Аппарат представлялся на международных выставках (Брюссель), запатентован в 6 странах и по лицензии поставлен фирмам в Австралию, Мексику, Боливию, Германию, Италию.

В монографии сделано обобщение работ по результатам исследований фильтрации расплавленного олова и свинца от твердых примесей.

Монография посвящена памяти С.Н. Сутурина и А.В. Долгова. 


\section{Гдава 1. ЦЕНТРОБЕЖНАЯ ФИЛЬТРАЦИЯ РАСПЛАВЛЕННОГО ОЛОВА}

В технологии производства цветных металлов из минерального сырья используются различные технологические приемы обогащения сырья от 0,1 до $50 \%$ основного металла. Плавкой обогащенного сырья с восстановителем получают металл, содержащий сопутствующие примеси.

Один из способов очистки цветных металлов от примесей основывается на отделении примесей, кристаллизующихся при охлаждении расплава.

Кроме общепринятого способа ликвационного рафинирования ручным отделением всплывающих в расплаве кристаллов примесей известно применение вакуумной фильтрации расплавов или фильтрационного отделения осадка из заливаемого расплава в поле центробежных сил.

\section{1. Основы диквационного рафинирования и обзор работ по фильтрации олова}

После восстановительной плавки в зависимости от сортности концентратов получают черновое олово содержащее примеси (вес \%): 0,1-2 железа; 0,1-3 мышьяка; 0,1-0,4 меди; 0,03-0,12 сурьмы; $0,15-6$ свинца; $0,1-0,6$ серы; $0,05-0,1$ висмута; $0,01-0,02$ индия. Железо и мышьяк образуют с оловом интерметаллические соединения $\mathrm{FeSn}$, $\mathrm{FeSn}_{2}, \mathrm{SnAs}, \mathrm{Sn}_{2} \mathrm{As}_{3}$ которые имеют ограниченную растворимость в олове и при температурах рафинирования $250-450{ }^{\circ} \mathrm{C}$ выделяются в кристаллы различной крупности.

Различие плотности соединений примесей и жидкого олова является основой ликвационного рафинирования, т. е. разделения по удельным весам. Однако, ликвация зависит не только от различия удельных весов, но и от взаимной растворимости, образования соединений, температуры плавления этих соединений, от изменения вязкости расплава и поверхностного натяжения расплава на границе твердых фаз. Черновое олово подвергали рафинированию от твердых интерметаллических соединений примесей путем последовательного вмешивания при соответствующих температурных режимах таких реагентов, как уголь, сера, алюминий, хлористый аммоний, хлористое олово. Кристаллы примесей вручную удаляли с поверхности металла в виде съемов, содержащих $60-85 \% \mathrm{Sn}$. Операция сопровождалась интенсивным выделением хлористого аммония, который усугублял антисанитарные условия на рабочем месте 
и снижал эффективность работы пылеулавливающих устройств. Ликвационные процессы имеют высокую трудоемкость операций отделения съемов и высокий выход олова в съемы. Поэтому исследователи неоднократно возвращались к процессу отделения жидкого металла от твердых примесей фильтрованием.

В ранних источниках [1] упоминается, что на заводе «Трейл» (Канада) черновое олово, содержащее до $0,4 \%$ железа, направляют на фильтр, состоящий из колоколообразной обогреваемой камеры с перфорированным днищем, покрытым асбестовым фильтром. Под давлением сжатого воздуха олово, залитое в обогреваемую до $425^{\circ} \mathrm{C}$ камеру, продавливают через асбестовый фильтр, уложенный на перфорированное днище. Отфильтрованное олово содержит $0,006 \%$ железа. Осадок на фильтре содержит $80 \%$ олова и $9,5 \%$ железа.

Мурач Н.Н. [2] изучал фильтрование олова под вакуумом в лабораторных и полузаводских условиях. Исследовал различные фильтрующие материалы: асбест, стекловата, пористый графит. Определил, что определяющим фактором является температура фильтрации.

На полупромышленной установке (рис. 1.1) исследовал отделение олова от железа фильтрованием под вакуумом 2-5 МПа через пористую графитовую пластину.

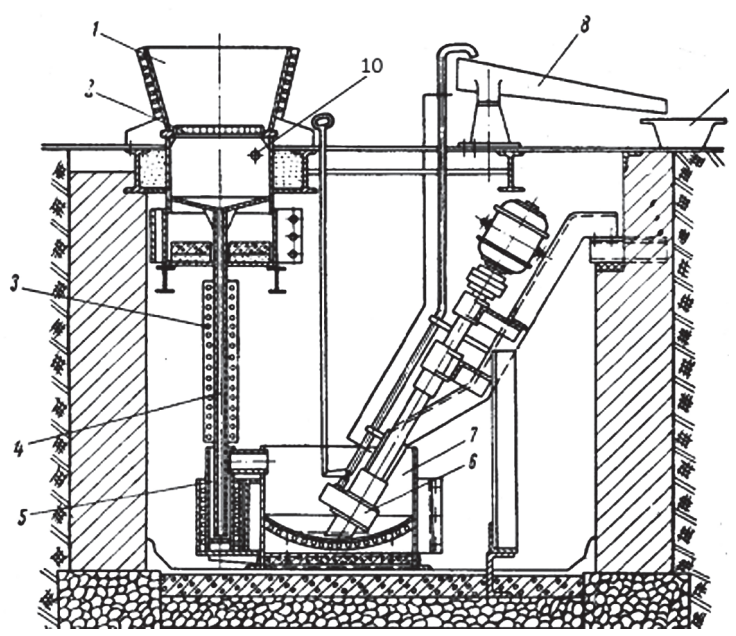

Рис. 1.1. Установка вакуумной фильтрации Мурач Н.Н.

Основные узлы: 2 - графитовый фильтр; 4 - барометрическая труба; 6-насос; 10 - вакуумпровод 
Производительность фильтра 1 т/см².мин). Олово после фильтрования содержало $0,03 \%$ железа и выход фильтрата был низким.

Особым направлением развития процесса фильтрования основано на использовании центробежных сил. Для рафинирования олова от железа и мышьяка разработан способ [3] фильтрации расплава продавливанием через слой инертного материала под действием центробежных сил.

Для испытания способа разработана и испытана опытная модель лабораторной центрифуги для разделения суспензии [4]. В центрифугу (рис. 1.2) заливают суспензию в приемную воронку 26 и отверстия 27, 28. Жидкое олово под действием центробежных сил продавливается через щелевой канал 16 между диском 10 и ротором 2 в кольцевой приемник 23. Осадок шнеком 3 транспортируется в окно 5.

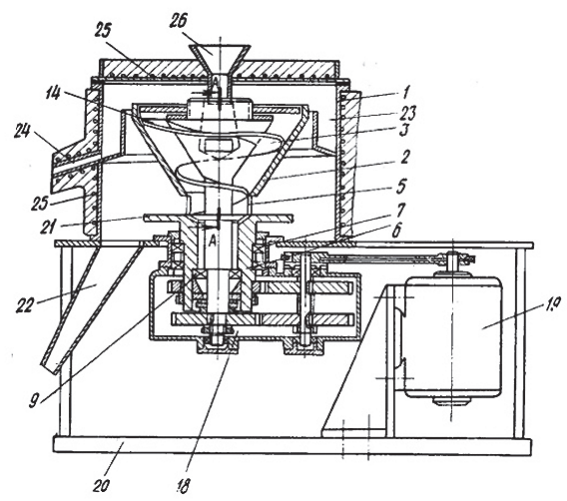

a

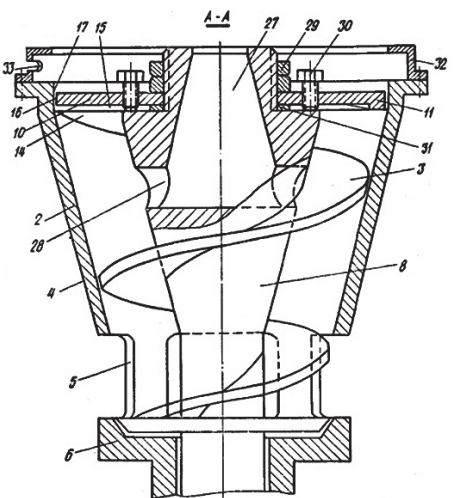

6

Рис. 1.2. Центрифуга заливная для фильтрации олова.

Основные узлы: 2 - ротор в виде конусного цилиндра; 3 - шнек; 5 - окна разгрузки; 10 - диск; 16 - щелевой канал; 23 - кольцевой приемник слива олова

Гораздо большей фильтрующей поверхностью обладало устройство описанное в источнике [5]. Центробежное фильтрование осуществлялось во вращающемся цилиндре с перфорированными стенками. Перед запуском в ротор аппарата засыпали песок. В качестве фильтра испытали слой песка, гранулированного шлака, коксика, керамической крошки или асбестовую ткань. Черновое олово при температуре $400^{\circ} \mathrm{C}$ заливали также в ротор. Съемы выбрасывались толкателем, приводимым в движение гидроцилиндром. В одном из вариантов олово фильтровалось через периферические отверстия в роторе диаметром 762 мм. Ротор обогревали газовыми горелками. Олово в ротор подавали сверху по центральной трубе. 
В аппарате фирмы «Клекнер Гумбольд» [6] металл также заливали в корзину ротора по центральной трубе. Корзина ротора футерована хромированным листом. Отфильтрованный от железа металл выбрасывался при температуре $260^{\circ} \mathrm{C}$ через кольцевые отверстия. Ротор обогревали газовыми горелками (рис. 1.3).

Центрифуги для отделения олова фильтрованием использовали на заводе «Пелтим» (Индонезия). Центробежное фильтрование осуществляется во вращающемся цилиндре с перфорированными стенками. Черновое олово при температуре $400^{\circ} \mathrm{C}$ заливали также в ротор. Твердый дросс FeSn выделяется и высушивается центрифугой, а отфильтро-

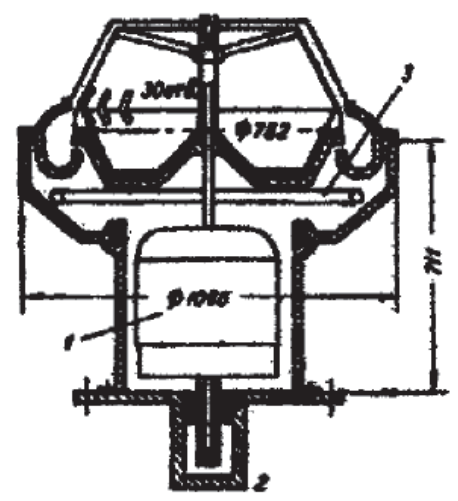

Рис. 1.3. Центрифуга для фильтрования металла (заливная): 1 - ротор;

2 - эластичный подшипник; 3 - кольцо для нагрева газом ванный металл охлаждался вплоть до температуры точки плавления. Кристаллы $\mathrm{FeSn}_{2}$ оседают, а оставшаяся жидкость откачивается в большой котел. При температуре на несколько градусов выше точки плавления, черновое олово с заполнененого котла откачивается во второй большой котел, а остаток в первом котле замораживается на стальную болванку и транспортируется в небольшой котел для заливки в центрифугу. При использовании такой системы дросс с содержанием 23-25\% Fe, движется навстречу печному металлу. Отрафинированное олово содержит $0,005 \% \mathrm{Fe}$.

Известна центрифуга Bergsoe [7] с фильтром-корзиной погружаемой в расплавленное олово, которую позже более подробно описана в работе Muller и Pascher [6]. Центрифуга Bergsoe (рис. 1.4) с радиусом 30 см, вращающаяся с максимальной скоростью 650 об/мин в котле диаметром 1,9 метра.

Центрифуга рафинирует 15-20 тонн за 8 часов. Дросс с содержанием $20 \%$ Fe получается из 15 тонн печного металла с содержанием $2,7 \%$ $\mathrm{Fe}$, или из 20 тонн при исходном содержании в $2 \% \mathrm{Fe}$. Недостатками конструкций центрифуг заливного типа являются трудное термостатирование вращающегося фильтра и исходного расплава, необходимость равномерной заливки неоднородного чернового олова. Кроме того, в описанных центрифугах имеет место неравномерное качество полученного готового продукта. В начале фильтрования пока фильтр не забит твердым осадком мелкие частицы примесей проскакивают через шели 
фильтра и переходят в готовый продукт. По мере забивания щелей чистота готового продукта повышается. Для получения чистого олова необходимо пропустить его через центрифугу несколько раз, причем каждый раз при более низкой температуре [8], что снижает производительность оборудования.

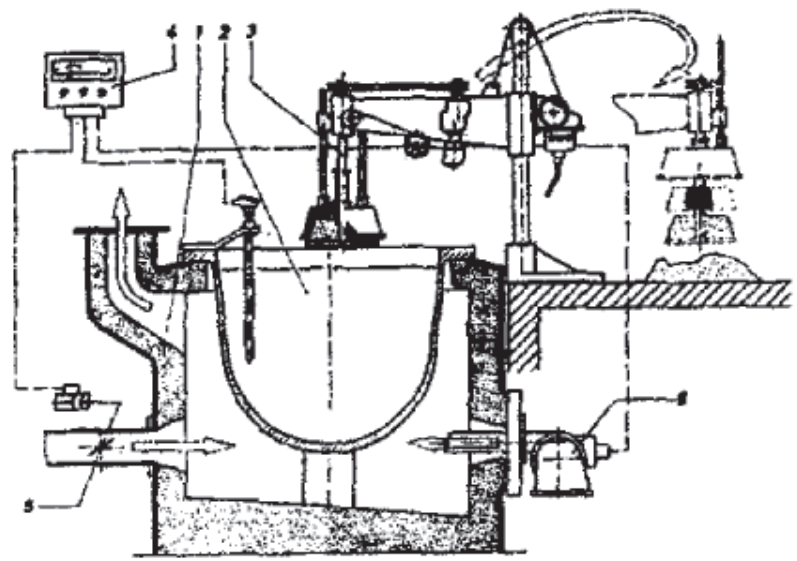

Рис. 4.1. Установка Вегgsое фильтрования олова погружным с фильтром: 1 - корпус печи обогреваемый газом; 2 - котел для олова;

3 - ротор центрифуги с цилиндрическим фильтром; 4 - пульт контроля; 5 - регулятор поддува топки; 6 - форсунка

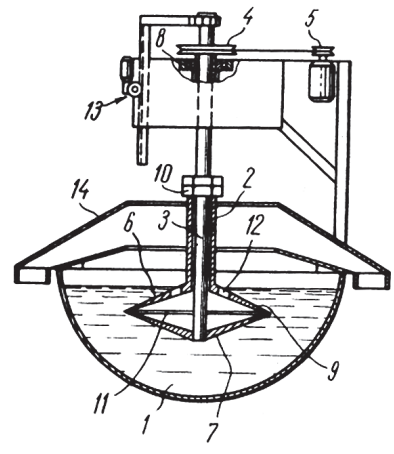

Рис. 1.5. Центрифуга лабораторная с погружаемым фильтром: Узлы: 6- фильтр;

7, 9- тарели; 11 -щель; 12 - окно забора

Указанные недостатки устраняются при использовании погружаемого фильтра (рис. 1.5) [9]. Фильтр для центрифуги погружного типа был выполнен в виде двух конусообразных тарелей, обращенных одна к другой и сжатых торцами больших оснований, зазор между которыми образует фильтрующую щель.

Одна из тарелей имеет отверстия, расположенные у вершины конуса, которые служат для втягивания расплава в полость фильтра. Размер фильтрующей щели регулируется при необходимости. Ротор с фильтром соединен с механизмами вращения и возвратно-поступательного перемещения вдоль продольной оси и механизмом раскрывания тарелей. Фильтр погружают 
в расплавленное олово и приводят во вращение. В полость фильтра втягивается расплавленное олово. Жидкий металл продавливается через фильтрующие щели и возвращается в ванну с металлом, а твердые примеси накапливаются в полости фильтра. По мере накопления твердого осадка в полости фильтра его поднимают над расплавом и отфильтровывают от остатков жидкого металла. Способ позволяет вести фильтрование расплавленного металла с постепенным его охлаждением вплоть до температуры, на $5-15^{\circ} \mathrm{C}$ превышающей точку замерзания.

Лабораторная центрифуга состоит из ванны 1 с расплавом, над которой установлен ротор 2, вал которого соединен через привод 4. К нижней части ротора 2 жестко прикреплен фильтр 6, погружаемый в расплав. Фильтр 6 состоит из двух конусообразных тарелей 7, 9, обращенных одна к другой основаниями. Нижняя тарель 7 жестко насажена на вал 3 , размещенный в обойме шарикового подшипника 8 с помощью скользящей шпонки. Верхняя тарель 9 жестко соединена с нижней частью ротора 2, но может перемещаться по валу 3 и стопориться в заданном положении с помощью механизма 10. Зазор между тарелями 7, 9 образуют фильтрующую щель 11, величина которой регулируется механизмом 10. На тарелях 7 или 9 в верхней части конуса имеются отверстия 12 для забора расплава. Ротор с фильтром 6 соединен механизмом 13 для осуществления возвратно поступательного перемещения вдоль оси [9].

Под действием центробежных сил жидкий расплав выбрасывается из фильтра 6 через через фильтр у щели 11 собирается масса твердых примесей, которые в свою очередь, служат фильтром для более мелких частиц. После заполнения внутренней полости фильтра 6 твердыми примесями, фильтр 6 с ротором 2, не прекращая их вращения, поднимают с помощью подъемного механизма 13 выше уровня расплава, где под действием центробежных сил твердые примеси отфильтровываются от остатков жидкого расплава. Затем фильтр 6 поднимают к бункеру 14, с помощью механизма 10 тарели 7, 9 разводятся на 3-10 см и под действием центробежных сил твердые примеси выбрасываются в бункер 14. После этого тарели 7, 9 сводят и опускают в расплав. Цикл повторяется до тех пор пока не будет достигнута необходимая степень очистки расплава.

Полупромышленная центрифуга (рис. 1.6) [10] снабжена фильтром 6 на валу 3, на котором жестко насажены диски 16, 17 и соединены с поршнем 13 для вертикального возвратно поступательного перемещения. Зазоры между дисками 16 и 17 и стенкой цилиндра 15 фильтр 6 образующие щели 18 для слива чистого металла. Для забора расплава в фильтр в диске 17 выполнено отверстие 19 [10]. 


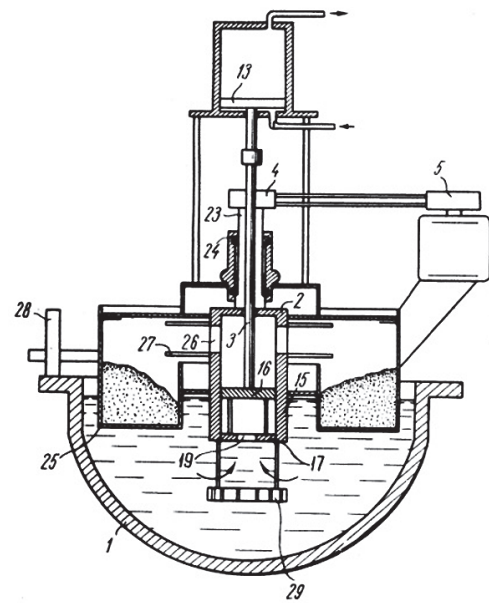

Рис. 1.6. Полупромышленная центрифуга с цилиндрическим фильтром.

Основные узлы: 15 - цилиндр; 17 - диск; 19 - отверстия всасывания расплава; 26 - разгрузочные окна
По мере вращения фильтра 6 расплав засасывается в отверстие 19 и под действием центробежных сил проходят через фильтрующую щель 18, образованную зазорами между дисками 16, 17 и внутренней стенкой цилиндра 15. При накоплении твердых примесей в фильтре, диски 16 и 17 с помощью поршня 13 совершают возвратно поступательное перемещение по 2-3 см для очистки фильтрующих щелей 18. После накопления в фильтре достаточного количества твердых примесей, поршнем 13 диски 16, 17 не прекращая их вращения, поднимают вверх до уровня разгрузочных окон 26 , через которые под действием центробежных сил твердые примеси выбрасываются в радиальных направлениях по направляющих дискам 27 на поддон 25.

По другому варианту [11] с целью увеличения производительности фильтрации стенки цилиндрического ротора выполнены сплошными, а диски поршня расположены с образованием кольцевого зазора между наружной кромкой их и внутренней поверхностью ротора. В такой центрифуге (рис. 1.7) фильтр 6 и состоит из полого цилиндра 15 , жестко соединенного с ротором 2. Внутри цилиндра 15 установлен верхний и нижний диски 16, 17 жестко соединенные с ротором 2 [11].

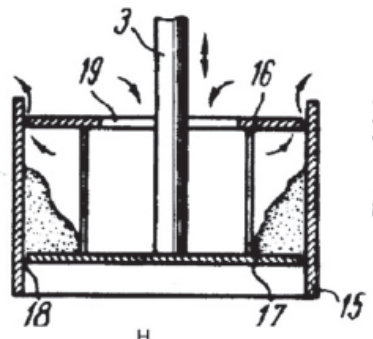

$\mathrm{H}$

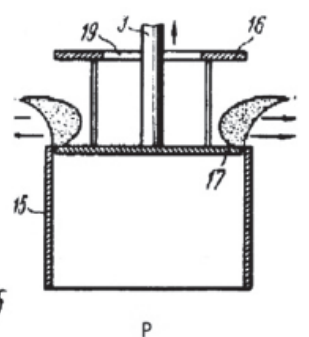

Рис. 1.7. Дисковый фильтр центрифуги.

Узль: 3 -вал; 15 - цилиндр; 16, 17 - диски; 18- фильтрующая щель; 19 - отверстие забора 
Внутри цилиндра 15 установлены верхний и нижний диски 16, 17, жестко насаженные на вал 3. Зазоры между дисками 16, 17 и стенкой цилиндра образуют фильтрующие щели 18. В одном из диском выполнено отверстие 19 для забора расплава. С целью повышения выхода готового продукта фильтрацию металла ведут с понижением температуры металла и осуществляют в слое покровного флюса с забором жидкого металла из под флюсового поверхностного слоя и выбросом его после фильтрации в слой флюса [12]. Фильтр (рис. 1.8) выполнен в виде перфорированного барабана 30, внутри которого находится скребок 31 , жестко соединенный с диском 16, насаженный на ротор 2. Скребок 31 предназначен для очистки фильтра 6 от осевших твердых примесей [12].

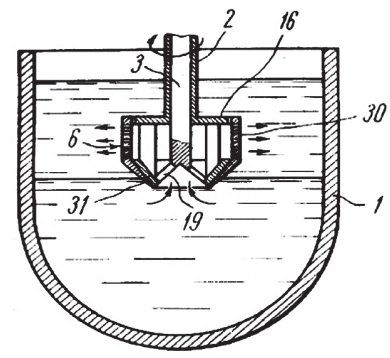

a

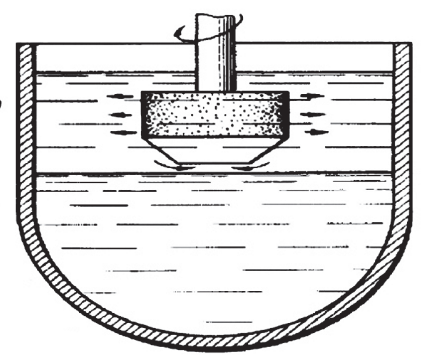

6

Рис. 1.8. Фильтр барабанный для способа фильтрации.

Узль: 2 - ротор; 6 - фильтр; $16-$-иск; 30-барабан; $31-$ скребок

Испытания и доработка лабораторных, укрупненных конструкций центрифуг с погружаемым фильтром силами Института гидродинамики СО РАН, СКБ ГИТ СО РАН, машиностроительного завода «Труд» и Новосибирского оловозавода привели к выпуску промышленного центробежного аппарата ПАФВС-650 (рис. 1.9).

Первое описание применения этой центрифуги приведено в работе [13].

Результаты промышленных испытаний рафинирования этой центрифугой (рис. 1.10) приведены в работах [14 и 15]. В монографии [16] наряду с описанием погружной центрифуги Bergsoe

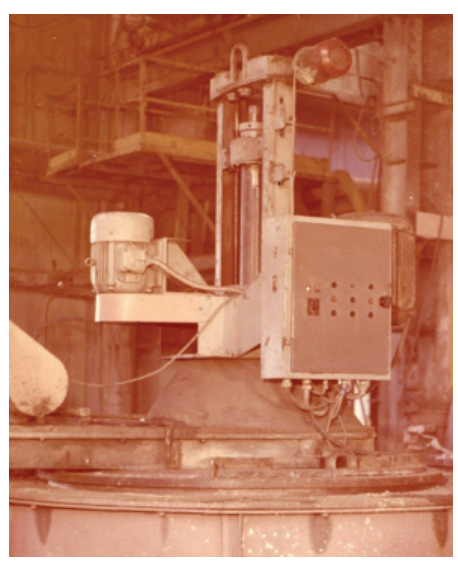

Рис. 1.9. Центрифуга ПАФВС-650в иехе 


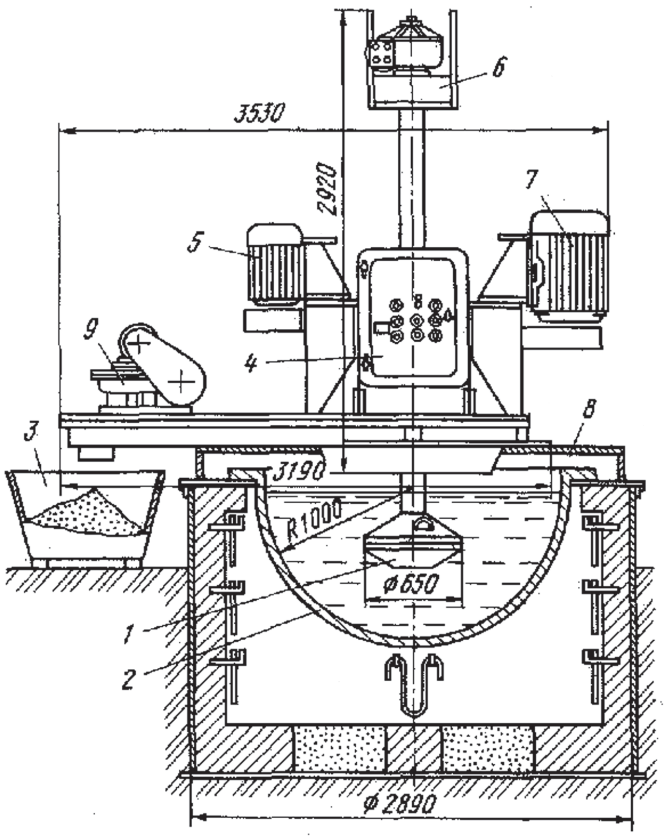

Рис. 1.10. Схема центрифуги ПАФВС-650. Основные узлы:

1 - ротор с фильтром; 2 - рафинировочный котел;

3 - кюбель для кристаллов; 4 - пульт управления;

5 -двигатель для отжмла; 6 - механизм подъема;

7 - двигатель вращения фильтра; 8 - бортовой отсос;

9 - привод транспортера фильтростатков дается краткое описание русской конструкции ПАФВС-650. Исследование центробежной фильтрации олова от железа и мышьяка погружаемым фильтром проводили на лабораторных центрифугах (рис. 1.5 и 1.11).

Фильтр центрифуги (рис. 1.11) [17] в виде двух конических тарелей диаметром 100 мм, обращенных друг к другу основаниями с зазором 0,1-0,2 мм и с образованием полости для накопления осадка. Фильтр погружался в олово, расплавленное в котле емкостью 10 л. Фильтр в расплаве приводился во вращение двигателем постоянного тока в течение $1-5$ мин со скоростью 300 об/мин. Периодически фильтр с кристаллами съемов

поднимали над поверхностью расплава и увеличили скорость его вращения до 1500 об/мин на 20-30 с. Происходила очистка осадка от жидкого металла. После этого останавливали вращение фильтра и верхнюю тарель освобождали и удаляли из полости фильтра съемы для взвешивания и анализа. При необходимости периодически отбирались пробы металла брызг из фильтра и металла из ванны котла. Цикл повторяли до полного удаления твердой фазы в расплаве, что определялось визуально по отсутствию осадка в тарелях. Пробы анализировалась на атомно-эмиссионном спектрометре с индуктивно связанной плазмой IRIS Intrepid компании INTERTECH Corporation. 


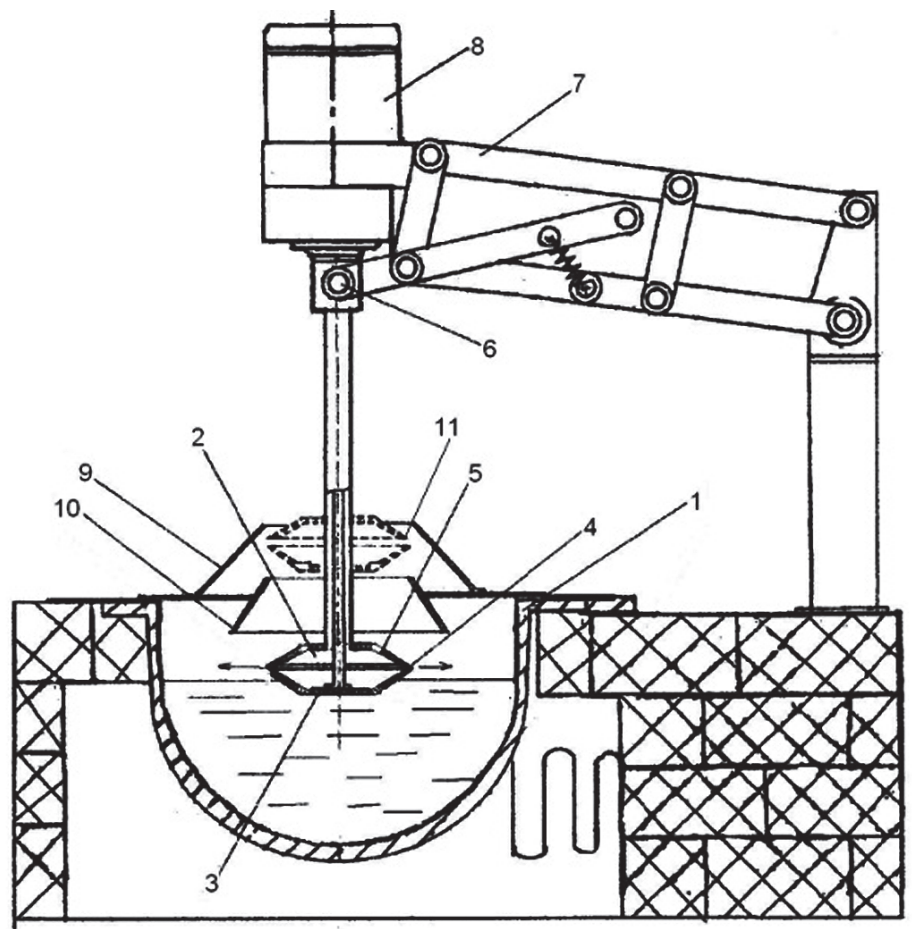

Рис. 1.11. Лабораторная центрифуга ЦП 100:

1 -котел; 2 - верхняя тарель; 3 - нижняя тарель; 4- фильтрующая щель;

5 - заборные окна; 6 - стопор раскрытия тарелей и разгрузки осадка из фильтра;

7 - механизм подбема фильтра; 8-двигатель вращения фильтра;

9 - съемный конус сбора дроссов; 10 - съемный конус сбора брызг из фильтра;

11 - уровень подъема фильтра для раскрытия тарелей и разгрузки осадка

Для определения влияния предварительного нагрева металла на выход съемов отливались образцы исходного металла весом 700 г и загружались в полость между тарелями. Тарели нагревались до температуры $300-550^{\circ} \mathrm{C}$, затем охлаждалась в течение 2 часов до температуры $300^{\circ} \mathrm{C}$ и проводилась фильтрация [18]. Некоторые образцы пористых кристаллов съемов из фильтра исследованы на фазовые формы мессбауэровской спектроскопией [19]. Образцы пористых кристаллов съемов из фильтра с разным содержанием олова исследованы [20] на удельную поверхность методом адсорбции аргона в институте катализа СО РАН. 


\section{2. Кинетика центробежной фильтрации олова от железа}

Рафинирование чернового олова начинают с удаления железа. Операцию ликвационного рафинирования от железа проводят вмешиванием каменого угля в ванну при температуре $400^{\circ} \mathrm{C}$. Кристаллы интерметаллических соединений железа $\mathrm{FeSn}$,, $\mathrm{FeSn}$ вместе с углем всплывают на поверхность и снимаются шумовкой [8]. Однако, одновременно с железом в осадок съемов выделяются соединения мышьяка с оловом и сложно оценить поведение индивидуальных соединений железа. Поэтому исследования условий фильтрации соединений железа проводили из отходов с ванн горячего лужения стали. При горячем лужении стального листа в расплаве олова на дне ванны агрегата лужения скапливается так называемый «тяжелый» металл твердых кристаллов $\mathrm{FeSn}_{2}$. «Тяелый» металл содержит 8-10\% железа [15].

Лабораторные опыты центробежной фильтрации отходов с ванн горячего лужения проводили на лабораторной центрифуге с диаметром фильтра 110 мм [9]. Отходы расплавляли, перемешивали при температуpe $550-600^{\circ} \mathrm{C}$, затем расплав охлаждали до заданной температуры фильтрации. Фильтр погружали на глубину 10-30 мм и вращали со скоростью 250 об/мин в течение 3-5 мин. После наполнения полости фильтра твердыми примесями (съемами) его поднимали над поверхностью расплава и увеличивали скорость вращения до 1200 об/мин в течение 20 с, после чего фильтр останавливали для выгрузки осадка и отбора проб. Результаты регенерации «тяжелого» металла приведены в табл. 1.1 [15].

Таблица 1.1

Результаты переработки «тяжелого» металла (олова с $8 \% \mathrm{Fe}$ )

\begin{tabular}{|l|c|c|c|c|c|}
\hline Температура фильтрации, ${ }^{\circ} \mathrm{C}$ & 540 & 500 & 450 & 400 & 350 \\
\hline Содержание Fе в съемах, $\%$ & 19,4 & 12,4 & 12,3 & 15,1 & 14,5 \\
\hline Sn в съемах, $\%$ & 79,7 & 86,9 & 85,9 & 84 & 84,9 \\
\hline Соотношение Sn/Fe & 4,12 & 7,03 & 7 & 5,6 & 5,9 \\
\hline
\end{tabular}

Результаты показывают, что с точки зрения относительного выхода олова в съемы предпочтительно проводить фильтрацию при температуре выше $500^{\circ} \mathrm{C}$. При понижении температуры ниже $500^{\circ} \mathrm{C}$ унос олова с железом возрастает вдвое, вероятно с повышением вязкости олова. Характерной особенностью рафинирования олова с высоким содержанием железа является осаждение кристаллов железистого олова на дно ванны и поэтому металл в котле непрерывно перемешивался пропеллерной мешалкой [15]. 
В табл. 1.2 приведена кинетика фильтрации железистого олова осадка от горячего лужения стали при $520^{\circ} \mathrm{C}$ с 3,53\% до 0,14\% Fe [21].

Таблица 1.2

Кинетика центробежного рафинирования олова от железа

\begin{tabular}{|c|c|c|c|c|c|c|c|}
\hline \multirow{2}{*}{$\begin{array}{c}\text { Момент, } \\
\text { мин }\end{array}$} & \multirow{2}{*}{$\begin{array}{c}\text { Металл } \\
\mathrm{Fe}, \%\end{array}$} & \multirow{2}{*}{$\begin{array}{c}\text { Выход } \\
\text { съемов, } \\
\%\end{array}$} & \multicolumn{2}{|c|}{$\begin{array}{l}\text { Анализ } \\
\text { съемов }\end{array}$} & \multirow{2}{*}{$\begin{array}{c}\text { Производи- } \\
\text { тельность, } \\
\text { кг/мин }\end{array}$} & \multirow{2}{*}{$\begin{array}{c}\text { Степень, } \\
\%, \text { удале- } \\
\text { ния Fe }\end{array}$} & \multirow{2}{*}{$\begin{array}{c}\text { Выход } \\
\mathrm{Sn} / \mathrm{Fe}, \%\end{array}$} \\
\hline & & & $\mathrm{Fe}, \%$ & $\mathrm{Sn}, \%$ & & & \\
\hline 0 & 3,53 & & & & & & \\
\hline 20 & 2,84 & 8,8 & 10,69 & 76,2 & 18 & 26,8 & 7,1 \\
\hline 60 & 2,15 & 10,2 & 8,83 & 71,2 & 20 & 50,0 & 8,1 \\
\hline 100 & 1,32 & 13,6 & 7,44 & 86,4 & 12 & 73,6 & 11,6 \\
\hline 140 & 0,48 & 10,5 & 8,46 & 86,2 & 8 & 91,4 & 10,2 \\
\hline 165 & 0,24 & 2,8 & 9 & 83,0 & 3 & 95,8 & 9,3 \\
\hline 235 & 0,21 & 0,4 & 8,9 & 85,4 & 0,14 & 96,4 & 9,5 \\
\hline 295 & 0,14 & 0,8 & 8,74 & 84,4 & 0,33 & 97,6 & 9,7 \\
\hline
\end{tabular}

Примечание. Фильтрация при температуре $520^{\circ} \mathrm{C}$ олова с исходным содержанием железа $3,53 \%$.

Ход кинетической кривой (рис. 1.12) показывает, что на начальном этапе при высокой концентрации суспензии кристаллов процесс идет с высокой интенсивностью [22].

На конечной стадии более $90 \%$ степени очистки скорость фильтрации снижается. Это можно объяснить уменьшением доли крупных кристаллов и увеличением доли мелких кристаллов. Процесс еще продолжается с малой скоростью наполнения фильтра, так как при фильтрации погружаемым фильтром крупные кристаллы задерживают более мелких кристаллы. Поэтому периодически вмешивался зернистый материал - каменный уголь. Причем, на конечных стадиях производительность фильтрации

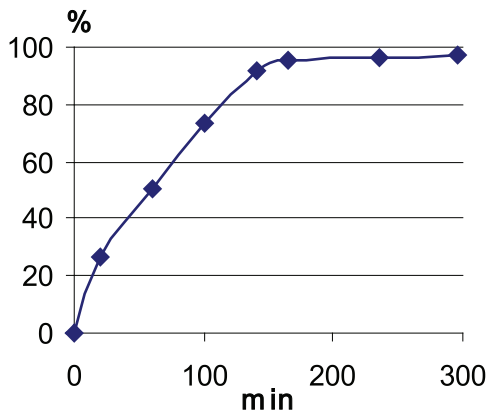

Рис. 1.12. Кинетика фильтрации расплава железистого олова.

Абсиисса - моменты отбора проб, ордината -степень \% очистки олова от железа 
без добавки каменного угля составляла 0,14 кг/мин, а после добавки угля 0,33 кг/мин. Как ранее показано низкий выход олова в отходы достигается фильтрацией при температуре более $500^{\circ} \mathrm{C}$, однако при этом не достигается необходимая степень очистки. В табл. 1.3 приведены опыты по определению влияния температуры на качество очистки олова.

Та бли ца 1.3

Влияние температуры фильтрации на качество очистки олова

\begin{tabular}{|l|c|c|c|c|c|c|}
\hline Температура фильтрации, ${ }^{\circ} \mathrm{C}$ & 550 & 500 & 500 & 500 & 350 & $\mathbf{3 0 0}$ \\
\hline Исходное содержание Fе в расплаве, \% & 6,67 & 4,48 & 2,11 & 1,02 & 0,12 & 0,065 \\
\hline Содержание Fe в съемах, \% & 20,8 & 13,7 & 5,67 & 2,85 & 6,76 & 1,38 \\
\hline Sn в съемах, \% & 77,1 & 85,3 & 87 & 92,4 & 87,1 & 93 \\
\hline Соотношение Sn/Fe & $\mathbf{3 , 7 1}$ & $\mathbf{6 , 1 8}$ & 15,4 & 32,3 & 12,9 & 74 \\
\hline Остаточное содержание Fe в расплаве, \% & 4,48 & 2,11 & 1,02 & 0,12 & 0,065 & $\mathbf{0 , 0 0 5}$ \\
\hline
\end{tabular}

В общем виде максимальная степень очистки и минимальный удельный выход олова в съемы достигается при нагреве металл до $450{ }^{\circ} \mathrm{C}$ с последующим охлаждением и фильтрацией при $300^{\circ} \mathrm{C}$. Поверхность кристаллов FeSn, $\mathrm{FeSn}_{2}$ обладают высокой смачиваемостью оловом. Крупные кристаллы имеют меньшую удельную поверхность и меньше задерживают олова на поверхности. Для снижения выхода олова со съемами требуется укрупнение кристаллов, чтобы снизить удельную поверхность кристаллов. После охлаждения расплава от 550 до $500^{\circ} \mathrm{C}$ в шлифе кристаллы $\mathrm{FeSn}_{2}$ под микроскопом имеют средний размер 0,08 мм. После охлаждения расплава от 550 до $300{ }^{\circ} \mathrm{C}$ средний размер кристаллов $\mathrm{FeSn}_{2}$ увеличивается до 0,32 мм. Это показывает, что для достаточного удаления железа с низким выходом олова в съемы существенно влияет кристаллизация расплава охлаждением расплава до минимальной температуры [20]. Кроме укрупнения кристаллов выход олова со съемами достигается снижением смачивания кристаллов примесей оловом путем окисления кристаллов с поверхности. При перемешивании чернового олова

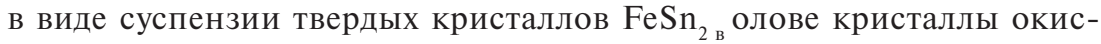
ляются с поверхности, становятся малосмачиваемые, и более легко отделяется свободное олово. Окисление олова на поверхности кристаллов основано на том, что поверхностные пленки с большей скоростью окисляются, чем в объеме металла. 
С увеличением скорости окисления (кг/мин) выход съемов увеличивается по уравнению:

$$
V_{i x} C=11,5 \cdot\left(V_{\text {ок }}\right)+1,5 \text { с корреляцией } 0,8 .
$$

где $V_{i x} C$ - выход съемов, \%; $V_{\text {ок }}-$ скорость окисления, кг/мин.

Излишне интенсивное и длительное перемешивание может вызвать дисспергирование металлического олова и возгорание съемов. Для снижения скорости окисления при перемешивании в расплав добавляют каменный уголь. Как показывает производственный опыт при выделении летучих компонентов разложения снижается окисление олова, но пленка на кристаллах FeSn 2 окисляется с поверхности.

Промышленное освоение технологии центробежной фильтрации отходов горячего лужения [15] осуществлено на Магнитогорском металлургическом комбинате. Отходы горячего лужения стали загружают и расплавляют в чугунном обогреваемом котле. На котел устанавливается центрифуга ПАВФС-650, фильтр которой погружается в расплав и приводится во вращение. Под действием центробежных сил отбрасывается к периферии полости фильтра, создавая разрежение, которое обеспечивает поступление металла в полость фильтра. Фильтр состоит из двух конусообразных тарелей, сжатых так что между ними образуется фильтрующая щель, в которой задерживаются твердые примеси. Для поступления рафинируемого металла в полость фильтра в тарелях у оси выполнены отверстия, так называемые заборные окна. Центробежные силы продавливают жидкое олово через щель фильтра и возвращают в ванну. Твердые примеси задерживаются у щели, накапливаясь в полости фильтра.

Таблица 1.4

Результаты баланса промышленных плавок удаления железа из олова ванны лужения

\begin{tabular}{|c|c|c|c|c|c|c|c|c|c|c|}
\hline \multirow{2}{*}{$\begin{array}{c}\text { № } \\
\text { П/ா }\end{array}$} & \multirow{2}{*}{$\begin{array}{l}\text { Тяжелый } \\
\text { металл, т }\end{array}$} & \multirow{2}{*}{$\begin{array}{l}\mathrm{Sn}, \\
\%\end{array}$} & \multirow{2}{*}{$\begin{array}{c}\text { Мас- } \\
\text { ляный } \\
\text { скраф, т }\end{array}$} & \multirow{2}{*}{$\begin{array}{l}\mathrm{Sn}, \\
\%\end{array}$} & \multirow{2}{*}{$\begin{array}{l}\text { Сред. } \\
\mathrm{Fe}, \%\end{array}$} & \multirow{2}{*}{$\begin{array}{c}\text { Полу- } \\
\text { чено } \\
\text { олово, т }\end{array}$} & \multirow{2}{*}{$\begin{array}{l}\text { Съе- } \\
\text { мы, т }\end{array}$} & \multicolumn{3}{|c|}{ Состав, \% съемов } \\
\hline & & & & & & & & $\mathrm{Fe}$ & $\mathrm{Sn}$ & $\mathrm{Sn} / \mathrm{Fe}$ \\
\hline 1 & 4,8 & 89 & 8,8 & 85 & 7,69 & 8,2 & 5,1 & 20,5 & 48 & 2,3 \\
\hline 2 & 12,5 & 87,9 & 0 & 0 & 7,56 & 7,5 & 5,4 & 17,5 & 50,3 & 2,9 \\
\hline 3 & 5,8 & 90 & 5,5 & 83,3 & 7,45 & 5,5 & 5,4 & 15,6 & 55,6 & 3,56 \\
\hline 4 & 1,8 & 94,6 & 11,5 & 81,9 & 7,55 & 7,2 & 5,4 & 18,6 & 64,9 & 2,95 \\
\hline 5 & 2 & 92,4 & 10 & 82 & 7,07 & 8,5 & 4,2 & 20,2 & 49,2 & 2,43 \\
\hline Итого & 26,9 & 89,3 & 35,8 & 82,9 & & 36,9 & 25,5 & & & \\
\hline
\end{tabular}


Фильтр, погруженный в рафинируемый расплав, работает в благоприятных термических условиях. Температура внутри фильтра соответствует температуре всего объема металла, что позволяет вести рафинирование в различных регулируемых температурных пределах, достигая максимальной степени удаления примесей.

На установке освоено рафинирование масляного скрафа и тяжелого металла с извлечением олова в готовый продукт 63,2\%. Железо содержащие оловянные отходы из ванн горячего лужения жести, плавят со сплавом $\mathrm{Si}-\mathrm{Al}$ с содержанием 3-15\% олова совместно с флюсовой скраф, содержащем $\mathrm{ZnCl}_{2}$ и расплав подвергают центробежной фильтрации при $470-540^{\circ} \mathrm{C}$ [23]. Для снижения потерь олова с хлоридными возгонами при переработке отходов из ванн горячего лужения жести, при температуре $510-620^{\circ} \mathrm{C}$ перед центробежной фильтрацией расплав обрабатывают известью или кальцинированной содой с последующей центробежной фильтрацией [24]. Предлагаемый способ позволяет снизить выход олова в съемы на 2-3\% повысить тем самым прямой выход олова в продукт. Промышленные результаты показывают, что при центробежной фильтрации со снижением температуры от 550 до $450{ }^{\circ} \mathrm{C}$ содержание железа снижается до 0,12\%. Дальнейшая фильтрация со снижением температуры до $300^{\circ} \mathrm{C}$ значительно повышает выход олова в съемы.

\section{3. Центробежная фильтрация олова от мышьяка с железом}

Основной операцией рафинирования олова можно признать это удаление мышьяка. Основная масса мышьяка удаляется в виде съемов тугоплавкого соединения мышьяка с железом. Поэтому предлагался способ выплавки чернового олова из оловосодержащих материалов так, чтобы мышьяк уже был связанным с железом. Для этого оловянные концентраты, содержащие мышьяк, смешивают с железистыми оборотными материалами (например с ванн лужения), до отношения в шихте железа к мышьяку 2-10 и плавят на шлаке, содержащем 4-10\% железа [25]. Полученное черновое олово рафинировали от мышьяка с железом центробежной фильтрацией. Однако, несмотря на положительные полупромышленные испытания, организационные трудности регулярной поставки и соблюдения дозировки компонентов шихты не создали условия к постоянному использованию.

\subsection{1. Кинетика очистки одова от мышьяка с железом фильтрацией}

Олово после рафинирования от железа содержится $0,1-0,3 \%$ As и до $0,12 \% \mathrm{Fe}$, растворенных в металле. Исследования кинетики центробежной фильтрации расплавленного олова от As c Fe проводили 
на лабораторной установке рис. 1.1 с тарелями диаметром 150 мм и зазором между ними 0,1 мм. Навеску 50 кг олова с содержанием $0,082 \%$ As и $0,065 \% \mathrm{Fe}$ нагревали до $550^{\circ} \mathrm{C}$ затем в течение 2 часов и охлаждали до $300^{\circ} \mathrm{C}$. Сбор твердых примесей в фильтр проводилось в течение 1 мин при скорости вращения фильтра 300 об/мин. Отжим фильтростатка (съемов) от жидкого олова проводилось в течение 30 с при скорости вращения 1500 об/мин. По ходу циклов фильтрации отбирались пробы брызг на выбросе металла из фильтра. Анализы брызг металла от каждого акта фильтрации практически одинаковы и в среднем содержали $\mathrm{Fe}-$ $0,024 \%$; As - 0,05\%. Результаты опытов по определению степени очистки олова от мышьяка с железом приведены в табл. 1.5 [26].

Таблица 1.5

Кинетика очистки олова от мышьяка с железом

\begin{tabular}{|c|c|c|c|c|c|c|c|c|c|c|c|}
\hline \multirow{2}{*}{$\begin{array}{l}\text { Длит., } \\
\text { мин }\end{array}$} & \multicolumn{3}{|c|}{ Анализ металла, \% } & \multicolumn{4}{|c|}{$\begin{array}{c}\text { Выделенные фильтро- } \\
\text { статки (съемы) }\end{array}$} & \multicolumn{2}{|c|}{$\begin{array}{c}\text { Степень, \%, } \\
\text { удаления }\end{array}$} & \multicolumn{2}{|c|}{ Ln (Meat) } \\
\hline & $\mathrm{Fe}$ & As & $\begin{array}{l}(\mathrm{Fe} / \mathrm{As}), \\
\mathrm{M}\end{array}$ & $\begin{array}{c}\text { Bec, } \\
\Gamma\end{array}$ & $\begin{array}{c}\mathrm{Fe}, \\
\%\end{array}$ & $\begin{array}{c}\text { As, } \\
\%\end{array}$ & $\begin{array}{l}(\mathrm{Fe} / \mathrm{As}), \\
\mathrm{c}\end{array}$ & $\mathrm{Fe}$ & As & $\mathrm{Fe}$ & As \\
\hline 1 & 0,058 & 0,069 & 0,84 & 160 & 2,24 & 4,23 & 0,5 & 11,0 & 16,5 & $-2,09$ & $-1,92$ \\
\hline 2 & 0,05 & 0,058 & 0,86 & 155 & 2,79 & 3,67 & 0,8 & 24,3 & 30,3 & $-2,25$ & $-2,1$ \\
\hline 3 & 0,04 & 0,047 & 0,85 & 150 & 3,41 & 3,73 & 0,9 & 40,0 & 43,9 & $-2,47$ & $-2,3$ \\
\hline 4 & 0,027 & 0,035 & 0,78 & 150 & 4,17 & 4,08 & 1,0 & 59,2 & 58,8 & $-2,84$ & $-2,6$ \\
\hline 5 & 0,014 & 0,024 & 0,58 & 135 & 4,97 & 4,24 & 1,2 & 79,8 & 72,7 & $-3,53$ & $-2,99$ \\
\hline 6 & 0,008 & 0,019 & 0,45 & 50 & 5,28 & 4,93 & 1,1 & 87,9 & 78,7 & $-4,03$ & $-3,22$ \\
\hline 7 & 0,006 & 0,016 & 0,35 & 30 & 4,61 & 5,04 & 0,9 & 92,2 & 82,3 & $-4,44$ & $-3,4$ \\
\hline
\end{tabular}

Приведенные в табл. 1.5 результаты опытов показывают, что содержание As и $\mathrm{Fe}$ в металле ванны планомерно снижается соответственно повышению степени очистки. Отмечаются высокие потери олова представленные в виде отношения к единице удаленных примесей равном $\mathrm{Sn} /(\mathrm{Fe}+\mathrm{As})=14,5$.

Кинетика процесса рис. 1.13 показывает, что степень очистки олова от As протекает одинаково со степенью очистки от Fе. Это можно объяснить тем, что мышьяк отделяется в виде FeAs [22].

Вывод, что мышьяк удаляется в виде соединения FeAs, подтверждает сравнение на рис. 1.14 соотношения (Fe/As) в металле и твердом осадке. 


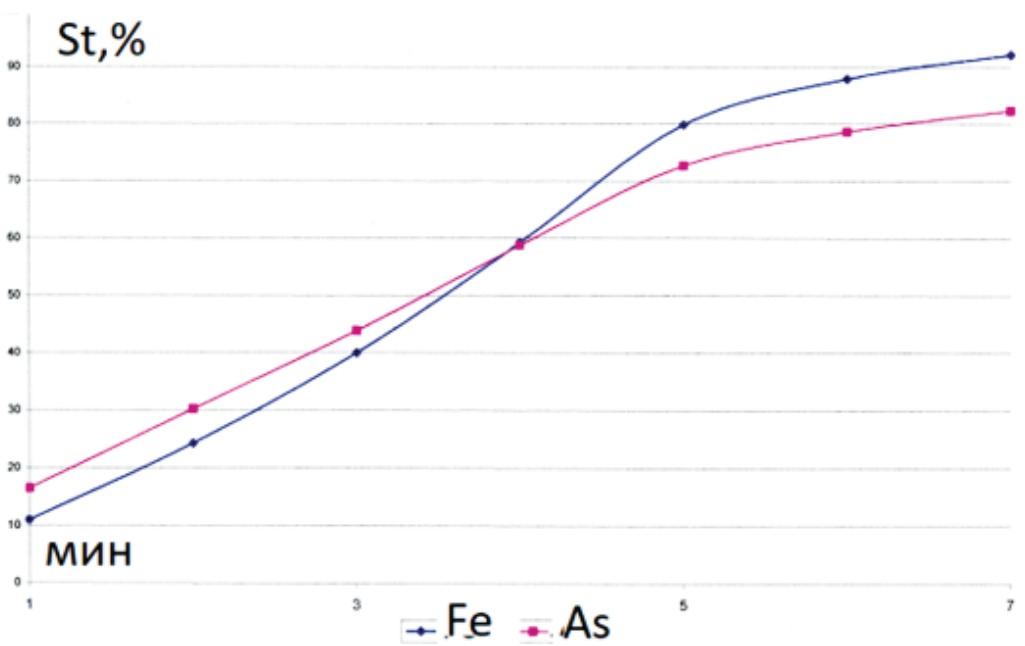

Рис. 1.13. Кинетика очистки олова от железа и мышьяка.

По абсциссе - мин; по ординате - степень \% удаления

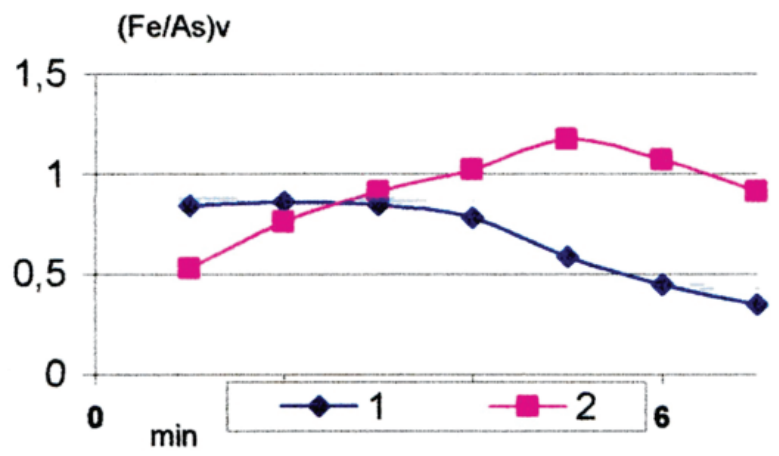

Рис. 1.14. Изменение соотношения (Fe/As) в металле и съемах по ходу фильтрации.

По абсииссе - длительность в мин; по ординате - соотношение в вес \%;

1 - в металле; 2 - в отфильтрованных съемах

Отделяемые железо-мышьяковистые съемы проверялись на способность выделять мышьяковистый водород при их смачивании водой. Выделения мышьяковистого водорода $\mathrm{AsH}_{3}$ не обнаруживалось. Выделение $\mathrm{AsH}_{3}$ из навески пробы, смоченной водой в закрытом объеме, определялось по стандартной фотометрической методике сравнением окраски реакции мышьяковистого водорода с диэтилдитиокарбаматом серебра в пиридине. 


\subsection{2. Циркуляция расплава через фильтр}

По мере наполнения фильтра съемами отфильтрованный металл через щель возвращается в ванну котла, постепенно снижая содержание примесей. Чтобы заполнить объем полости фильтра кристаллами примесей необходимо, чтобы через щель фильтра профильтровался определенный объем металла из ванны котла. Объем металла $V_{f}$, однократно прошедшего через фильтр по результатам приведенных в табл. 1.3 рассчитан по формуле:

$$
V_{f}=\left(\mathrm{Fe}_{c}+\mathrm{As}_{c}\right) \cdot B_{\mathrm{c}} \cdot 0,01 /\left(\left(\mathrm{Fe}_{k}-\mathrm{Fe}_{f}\right)+\left(\mathrm{As}_{k}-\mathrm{As}_{f}\right)\right),
$$

где $\mathrm{Fe}_{c}, \mathrm{As}_{c}$ - содержание соответственно $\mathrm{Fe}$ и $\mathrm{As}$ в съемах цикла; $B_{\mathrm{c}}-\mathrm{Bec}$ съемов; $\mathrm{Fe}_{k}, \mathrm{As}_{k}$ - содержание соответственно $\mathrm{Fe}$ и $\mathrm{As}$ в котле цикла; $\mathrm{Fe}_{f}$, $\mathrm{As}_{f}-$ содержание соответственно Fе и As в брызгах фильтра.

Жидкий расплав с частью мелких кристаллов выбрасывается из фильтра в ванну расплава. При фильтрации погружаемым фильтром крупные кристаллы являются «сеткой» для задерживания более мелких кристаллов. В начальный период при высокой концентрации суспензии крупных кристаллов в олове через фильтр проходит 159 кг, т.е. в 3 раза больше чем вес исходной загрузки. На конечных циклах фильтрации объем металла прошедшего через фильтр увеличивается и превышает в 10 раз исходную загрузку. Это показывает что происходит многократная циркуляция металла через фильтр. В ванне накапливаются мелкие кристаллы, а концентрация крупных кристаллов снижается. Для заполнения объема фильтра требуется более длительная циркуляция расплава через фильтр.

На рис. 1.15 показано изменение содержания Fe и As в олове ванны с увеличением циклов фильтрации. Содержание As в котле снижается в меньшей степени, чем Fe.

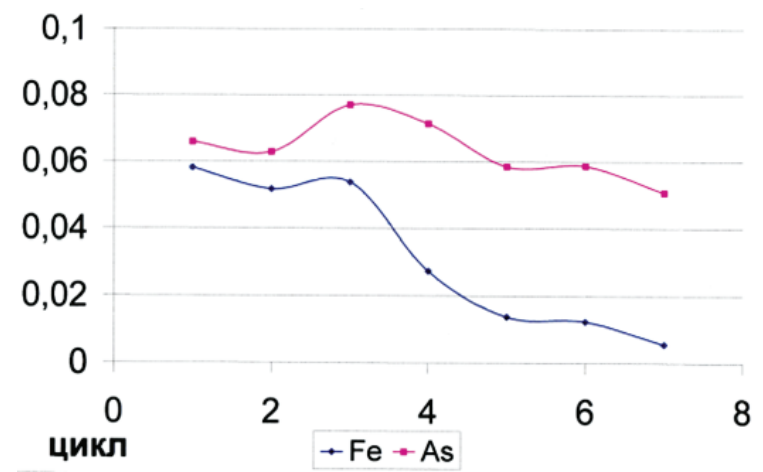

Рис. 1.15. Изменение состава рафинируемого металла в котле 
По ходу фильтрации содержание Fe в котле как показано на рис. 1.15 снижается по уравнению:

$$
(\mathrm{Fe})_{k}=0,07-0,01 \cdot N \text { с корреляцией 0,91. }
$$

где $N$ - порядковый номер цикла разгрузки фильтра; $(\mathrm{Fe})_{k}-$ содержание $\mathrm{Fe}$ в ванне котла после цикла фильтрации.

\subsection{3. Выход одова в съемы при разном соотношении Fe/As}

Выход олова на единицу удаляемых примесей $\mathrm{Sn} /(\mathrm{Fe}+\mathrm{As})$ с каждым циклом практически остается постоянным. Однако, как показано на рис. 1.16, если на 4 цикле фильтрации выход олова в съемы несколько повышается, а потом на 6 цикле резко повышается. Это можно объяснить тем, что вначале мышьяк удаляется с железом FeAs, а на конечных циклах удаляется в виде мелких кристаллов AsSn при низкой температуре.

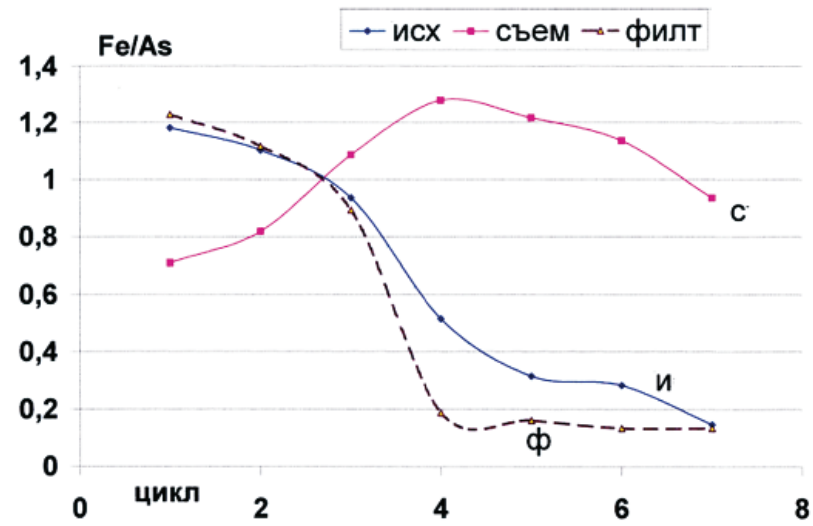

Рис. 1.16. Сравнение изменения соотношения $\mathrm{Fe} / \mathrm{As}$ по ходу циклов рафинирования

Это свидетельствует о том, что на начальных циклах циркуляция расплава через фильтр оказывает положительное влияние на показатели, то на конечных циклах оказывает отрицательное влияние. Работа центрифуги в автоматическом режиме на излишних циклах, когда соотношение $\mathrm{Fe} / \mathrm{As}$ снизилось, способствует повышению выхода олова в съемы [22].

На рис. 1.16 показано, что соотношение Fe/As в рафинируемом металле планомерно снижается, а в съемах повышается. В брызгах металла из фильтра соотношение Fe/As сначала равномерно уменьшается, потом на 4 цикле резко снижается. На этом цикле фильтрацию можно было прекращать и не повышать выход олова в съемы. 


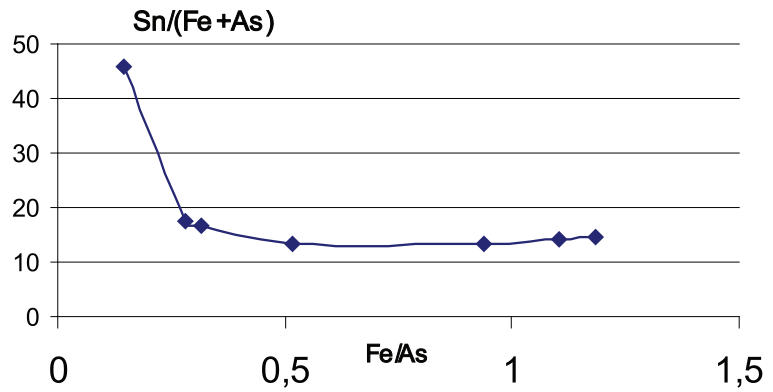

Рис. 1.17. Влияние соотношения Fe/As в металле на выход олова в сбемы

В дополнение к этому рис. 1.17 показывает, что при соотношении $\mathrm{Fe} / \mathrm{As}<0,3$ резко повышается выход олова в съемы, а в металле еще остается мышьяк, растворенный в олове. Это объясняется тем, что при низком содержании железа в металле мышьяк выделяется в съемы в виде мелких кристаллов AsSn при низкой температуре. Результаты показали, что оптимизация параметров степени очистки и выхода олова в съемы в целом зависит от соотношения $\mathrm{Fe} / \mathrm{As}$.

\subsection{4. Термодинамика и физико-химические исследования фаз мышьяка в одове}

Термодинамический расчет изобарного потенциала образования соединений мышьяка по исходным данным [27] показывает последовательность возрастания прочности соединений в ряду: $\mathrm{SnAs}, \mathrm{FeSn}_{2}$, FeAs. $\mathrm{B}$ соответствии с этим рассчитали распределение примесей и олова по фазовому составу. В съемах железо в первую очередь связано с мышьяком, а избыток Fe или As от этой связи считали связанными с оловом. По диаграмме состояния при $T<595^{\circ} \mathrm{C}$ мышьяк до содержаний $3,6 \%$ находится в растворенном состоянии, но активность его снижена равновесной реакцией диссоциации соединения $\mathrm{AsSn}\left(595^{\circ} \mathrm{C}\right)$.

$$
\mathrm{AsSn}=\mathrm{As}+\mathrm{Sn} . . . \Delta Z_{400}^{\circ \mathrm{C}}=-10,6 \text { кДж/мол. }
$$

Возможна реакция между растворенным Аs и $\mathrm{FeSn}_{2}$ с образованием FeAs, но с некоторым торможением за счет реакции диссоциации соединений $\mathrm{AsSn}$ и $\mathrm{FeSn}_{2}$.

По диаграмме состояния систем [28] в расплаве олова при $T<495^{\circ} \mathrm{C}$ железо находится в виде фазы $\mathrm{FeSn}_{2}$. Поэтому предпочтительно лигатуру $\mathrm{FeSn}_{2}$ загружать при более высокой $T>500^{\circ} \mathrm{C}$, а фильтровать после снижения температуры. 


$$
\begin{gathered}
\mathrm{As}+\mathrm{FeSn}_{2}=\mathrm{FeAs}+2 \mathrm{Sn} \cdot \Delta Z_{400}^{\circ}=-28,1 \text { кДж/мол; } \\
\mathrm{AsSn}+\mathrm{FeSn}_{2}=\mathrm{FeAs}+3 \mathrm{Sn} \cdot \Delta Z_{400}^{\circ \mathrm{C}}=-38,8 \text { кДж/мол. }
\end{gathered}
$$

Фильтрация мышьяка в виде AsSn возможна при температуре менее $300^{\circ} \mathrm{C}$, а при более высокой температуре соединение диссоциирует.

Для получения дополнительной информации о фазовом составе съемов и чернового олова сняты ЯГР спектры фильтратов сплавов с разным соотношением железо-мышьяк (рис. 1.18). Мессбауэровские спектры ${ }^{119} \mathrm{Sn}$ снимались на спектрометре MS-10K с источником $\mathrm{BaSnO}_{3}$ [22].

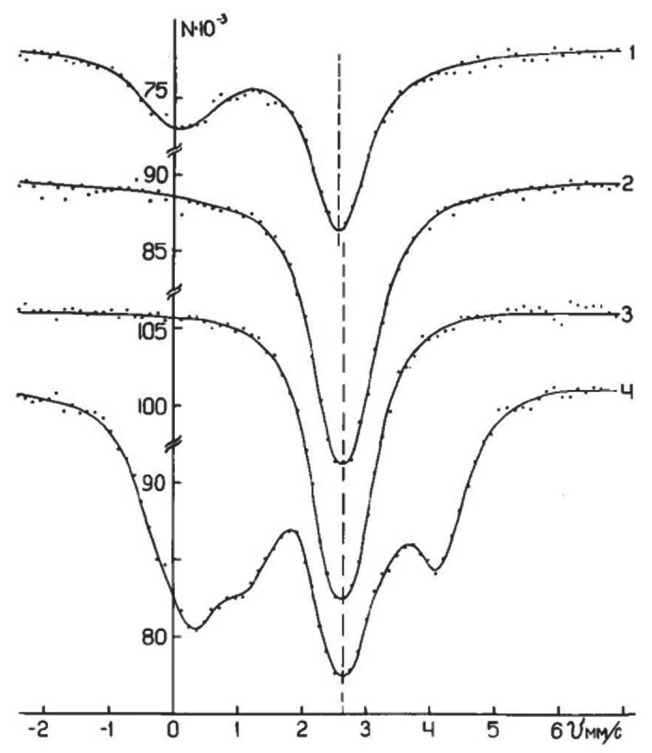

Рис. 1.18. Мессбауэровские спектры ${ }^{119}$ Sn проб:

1 - проба олова с $\mathrm{Fe}-11,2 ; \mathrm{As}-14,9 ; \mathrm{Fe} / \mathrm{As}-1,0$;

2 - проба олова с $\mathrm{Fe}-4,8 ; \mathrm{As}-9,18 ; \mathrm{Fe} / \mathrm{As}-0,70$;

3 - проба олова с $\mathrm{Fe}-1,3 ; \mathrm{As}-7,3 ; \mathrm{Fe} / \mathrm{As}-0,24$;

4 - проба олова с $\mathrm{Fe}-7,9 ; \mathrm{As}-4,2 ; \mathrm{Fe} / \mathrm{As}-2,52$

$\mathrm{B}$ пробе 1 (с соотношением $\mathrm{Fe} / \mathrm{As}=1,0)$ по спектру ${ }^{119} \mathrm{Sn}$ олово находится в виде $\beta-\mathrm{Sn}$ и $\mathrm{SnO}_{2}$ и нет фаз взаимодействия олова с железом или мышьяком (рис. 1.18). При соотношении железа к мышьяку более низким, чем стехиометрическое (пробы 2,3 ) в спектрах ${ }^{119} \mathrm{Sn}$ наблюдается смещение линии вправо относительно $\beta-\mathrm{Sn}$, что указывает 
на взаимодействие олова с мышьяком. В том случае, когда железа больше, чем мышьяка (проба 4) взаимодействие между компонентами указывает на появление фаз типа $\mathrm{FeSn}_{2}$. Приведенные результаты подтверждают вероятность реакции (2) при рафинировании олова от железа с мышьяком центробежной фильтрацией. В пробе 1 (с соотношением $\mathrm{Fe}: \mathrm{As}=$ в стехиометрии) по спектру ${ }^{119} \mathrm{Sn}$ олово находится в виде $\beta-\mathrm{Sn}$ и $\mathrm{SnO}_{2}$ и нет фаз взаимодействия олова с железом или мышьяком (рис. 1.18). При соотношении железа к мышьяку более низким, чем стехиометрическое (пробы 2,3 ) в спектрах ${ }^{119} \mathrm{Sn}$ наблюдается смещение линии вправо относительно $\beta-\mathrm{Sn}$, что указывает на взаимодействие олова с мышьяком. В том случае, когда железа больше, чем мышьяка (проба 4) взаимодействие между компонентами указывает на появление фаз типа $\mathrm{FeSn}_{2}$. Приведенные результаты показывают закономерность рафинирования олова от железа с мышьяком центробежной фильтрацией [22].

\subsection{5. Тодщины пленки одова на кристалдах и укрупнение частиц кристалдизацией}

Повышенный выход олова в съемы объясняется не только связыванием его в соединения с примесями $\mathrm{SnAs}$ и $\mathrm{FeSn}_{2}$, но и в виде жидкой пленки по поверхности кристаллов. Поверхность кристаллов SnAs, FeSn 2 обладают высокой смачиваемостью оловом. Железо связывается с мышьяком, и при недостатке мышьяка то с оловом. Оставшийся мышьяк при недостатке железа связывается с оловом. Содержание жидкого олова в съемах определялся по разности анализа и олова расчетного с соединениях.

Объем пленки определялся делением расчетного содержания жидкого олова в съемах на плотность жидкого олова. Толщину пленки на кристаллах съемов определялся делением объема свободного жидкого олова на удельную поверхность [20]. В табл. 1.6 приведен расчет толщины пленки жидкого олова на кристаллах примесей на основе определения удельной поверхности образцов съемов по методу адсорбции аргона.

Результаты расчетов показывают влияние $\mathrm{Fe} / \mathrm{As}$ на толщину пленки олова на кристаллах съемов после центробежной фильтрации. Кристаллы покрыты пленкой олова, что вносит долю в повышении выхода олова в съемы. Чем меньше размер кристаллов, больше поверхность кристаллов и тем больше выход олова с поверхностной пленкой. Кроме того, с уменьшением температуры расплава повышается вязкость расплава и увеличивается толщина пленки олова на поверхности кристаллов [7]. 
Таблица 1.6

Расчет толщины пленки олова на кристаллах

\begin{tabular}{|c|c|c|c|c|c|c|c|c|c|c|}
\hline \multirow{2}{*}{$\begin{array}{l}\text { Номер } \\
\text { проб }\end{array}$} & \multicolumn{2}{|c|}{$\begin{array}{c}\text { Анализ } \\
\text { \% съемов }\end{array}$} & \multirow{2}{*}{$\begin{array}{c}\mathrm{Fe} / \mathrm{As} \\
\mathrm{mol}\end{array}$} & \multirow{2}{*}{$\begin{array}{c}S, \\
\mathrm{M}^{2} / \Gamma\end{array}$} & \multicolumn{3}{|c|}{$\begin{array}{c}\text { Процент тверд со- } \\
\text { единений }\end{array}$} & \multirow{2}{*}{$\begin{array}{c}\mathrm{Sn}, \%, \\
\text { жидкого }\end{array}$} & \multirow{2}{*}{$\begin{array}{c}V_{\text {жид }}, \mathrm{cm}^{3} \\
\text { съемов } \\
1 \text { г }\end{array}$} & \multirow{2}{*}{$\begin{array}{c}\delta_{\text {пл }}, \\
\text { микрон, } \\
\mu\end{array}$} \\
\hline & $\mathrm{Fe}$ & As & & & $\mathrm{FeAs}$ & $\mathrm{FeSn}_{2}$ & AsSn & & & \\
\hline 1 & 13 & 6,8 & 2,56 & 0,2 & 11,8 & 41,91 & 0 & 46,0 & 0,07 & 0,33 \\
\hline 2 & 2,43 & 4,3 & 0,76 & 0,2 & 5,7 & 0 & 2,602 & 83,0 & 0,12 & 0,60 \\
\hline 3 & 0,28 & 0,8 & 0,49 & 0,33 & 0,66 & 0 & 1,015 & 88,9 & 0,13 & 0,39 \\
\hline \multirow[t]{2}{*}{4} & 0,1 & 26 & 0,01 & 0,37 & 0,23 & 0 & 66,34 & 29,6 & 0,04 & 0,12 \\
\hline & & & & & & & & & средн & 0,36 \\
\hline
\end{tabular}

Примечание: $S$ - удельная поверхность образиа съемов по методу адсорбции аргона, $\delta_{n л}-$ толщина пленки олова в микронах, $\mu=10^{-6} \mathrm{M}$.

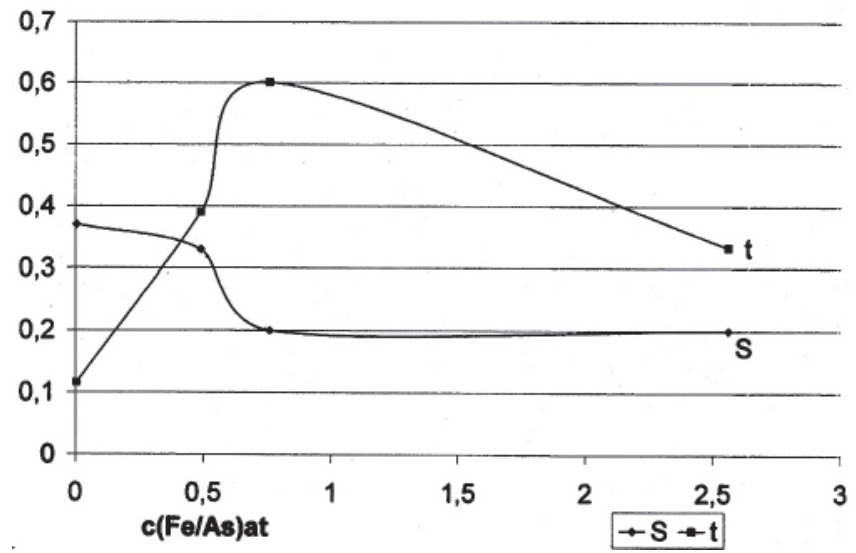

Рис. 1.19. Влияние состава металла на удельную поверхность $S$ и толщину $\delta$ пленки олова на кристаллах съемов.

По абсциссе - молярное соотношение Fe/As в исходном металле; по ординате:

$1-S-$ удельная поверхность, $\mathrm{M}^{2} / 2 ; 2-$ толщина пленки олова $\delta$ в микронах

Расчеты показали, что толщина пленки жидкого олова на кристаллах отфильтрованных съемов колеблется в интервале от 0,12 до 0,6 микрон. Перегиб на графиках рис. 1.19 показывает, что с увеличением соотношения (Fe/As) удельная поверхность несколько снижается, а толщина пленки сначала увеличивается, затем при соотношении $(\mathrm{Fe} / \mathrm{As})=0,76$ толщина пленки начинает уменьшается. Это по видимому объясняется тем, что при малых значениях $\mathrm{Fe} / \mathrm{As}<0,76$ мышьяк находится в виде 
фазы SnAs увеличивается доля связи железа в соединение FeAs, а затем появляется избыток фазы $\mathrm{FeSn}_{2}$. Крупные кристаллы имеют меньшую удельную поверхность и меньше задерживают олова на поверхности. С уменьшением температуры расплава повышается вязкость расплава и увеличивается толщина пленки олова на поверхности кристаллов [20].

По мере охлаждения расплава олова растворимость соединений примесей в олове снижается. Выделяющиеся из расплава соединения кристаллизуются на мелких кристаллах суспензии и размеры кристаллов увеличиваются.

Цель центробежной фильтрации полнее отделить жидкое олово, не связанное в соединения. Для укрупнения кристаллов металл нагревался до температур начала растворения кристаллов и охлаждался до температуры фильтрации. С увеличением температуры нагрева металла содержание железа в съемах $[\mathrm{Fe}]_{\mathrm{c}}$ незначительно уменьшается, а мышьяк $[\mathrm{As}]_{\mathrm{c}}$ в 5 раз более значимо уменьшается по уравнению:

$$
[\mathrm{As}]_{\mathrm{c}}=12,1-0,02 \cdot T \text { с корреляцией } 0,86 .
$$

Это объясняется тем, что кристаллы мышьяка растворяются с повышением температуры, но недостаточно укрупняются при охлаждении и поэтому увеличивается выход олова с кристаллами при увеличении вязкости олова.

По мере охлаждения расплава олова растворимость соединений примесей в олове снижается. Выделяющиеся из расплава соединения кристаллизуются на мелких кристаллах суспензии и размеры кристаллов увеличиваются. Чем меньше размер кристаллов, больше поверхность кристаллов, тем больше выход олова с поверхностной пленкой. В табл. 1.7 приведены результаты оценки влияния температуры начала кристаллизации [18].

Таблица 1.7

Влияние температуры начала кристаллизации

\begin{tabular}{|c|c|c|c|c|c|c|c|}
\hline \multirow{2}{*}{$\begin{array}{c}\text { Номер } \\
\text { опыта }\end{array}$} & \multirow{2}{*}{$\begin{array}{c}T_{\text {нагр }} \\
\text { металл }\end{array}$} & \multicolumn{2}{|c|}{ Состав съемов, \% } & \multirow{2}{*}{ Се/As) c } & \multirow{2}{*}{$\mathrm{Sn} /(\mathrm{Fe}+\mathrm{As})$} & \multicolumn{2}{|c|}{ Процент очистки } \\
\cline { 9 - 9 } \cline { 7 - 8 } & $\mathrm{Fe}$ & $\mathrm{As}$ & & & $\mathrm{Fe}$ & $\mathrm{As}$ \\
\hline 1 & 300 & 6,5 & 5,5 & 1,58 & 7,3 & 97,2 & 65 \\
\hline 2 & 350 & 6,68 & 5,6 & 1,60 & 7,1 & 97,8 & 67,2 \\
\hline 3 & 400 & 6,5 & 5,7 & 1,53 & 7,2 & 97,8 & 73,8 \\
\hline 4 & 450 & 5,6 & 4 & 1,88 & 9,4 & 97,6 & 62,1 \\
\hline 5 & 500 & 3,2 & 2,1 & 2,00 & 17,7 & 93,5 & 40,4 \\
\hline 6 & 550 & 7,45 & 2,6 & 3,84 & 8,95 & 94,6 & 29,8 \\
\hline
\end{tabular}

Примечание. Образеи металла нагревался до заданной температуры и охлаждался до температуры фильтраци - $300^{\circ} \mathrm{C}$. Исходный металл Fe - 0,18\%; As 0,22\%. Средний состав рафинированного олова $\mathrm{Fe}-0,006 \%$; $\mathrm{As}-0,088 \%$. 
Для снижения удельного выхода олова в съемы целесообразно прекращать фильтрацию после удаления основной массы железа. После удаления 94,3\% железа с мышьяком остается еще 0,1-0,3\% мышьяка растворенного в металле.

С увеличением температуры нагрева металла содержание железа в съемах $[\mathrm{Fe}]_{\mathrm{c}}$ незначительно уменьшается, а содержание мышьяка в съемах мышьяк [As] в 5 раз более значимо уменьшается по уравнению:

$$
[\mathrm{As}]_{\mathrm{c}}=12,1-0,02 \cdot T \text { с корреляцией } 0,86 .
$$

$\mathrm{C}$ увеличением температуры нагрева металла степень очистки от $\mathrm{Fe}$ фильтрацией незначительно уменьшается, а степень очистки от As уменьшается в 10 раз значимее по коэффициенту наклона прямой уравнения:

$$
S t_{\mathrm{As}}=138-0,2 \cdot T \text { с корреляцией } 0,8,
$$

где $S t_{\text {As }}-$ степень очистки олова от мышьяка.

Это объясняется тем, что кристаллы мышьяка растворяются с повышением температуры, но недостаточно укрупняются при охлаждении и поэтому увеличивается выход олова с кристаллами при увеличении вязкости олова.

Результаты центробежной фильтрации металла зависят от размеров кристаллов интерметаллических соединений примесей. В черновом олове от плавки концентратов основная масса соединений железа с мышьяком имеет размер кристаллов 0,003-0,005 мм, и только единичные зерна имеют размер $\sim 0,12$ мм. Для укрупнения кристаллов металл нагревают до температуры $550^{\circ} \mathrm{C}$ и постепенно снижают температуру. В это время происходит рост кристаллов интерметаллидов, размер которых к концу охлаждения достигает 0,2-5 мм. При температуре $300^{\circ} \mathrm{C}$ производится удаление образовавшихся кристаллов центробежной фильтрацией. Опыт показал, что отфильтрованные окисленные кристаллы примесей (так называемые «сухие» съемы) содержат олова меньше, чем отфильтрованные «жирные» фильтроостатки. При фильтрации чернового олова при температуре $450^{\circ} \mathrm{C}$ получаются съемы, содержащие $79 \%$ олова и в том числе 0,6\% - в виде окиси. После перемешивания такого же чернового олова, содержащего 0,19\% железа и 0,68\% мышьяка, в течение 50 мин при температуре $550^{\circ} \mathrm{C}$ получаются сухие съемы. Отфильтрованные при температуре $450{ }^{\circ} \mathrm{C}$ сухие съемы содержат (\%): 5,54 - железа; 8,24 - мышьяка; 72 - олова и в том числе 2,9 - окисленного олова. Это можно объяснить тем, что окисленные сухие съемы не смачиваются оловом. Для определения оптимальной температура окисления кристаллов примесей и недопущения выхода большого количества олова были поставлены опыты 
на укрупненной лабораторной установке опытного цеха. Диаметр котла 350 мм, длина лопасти двухлопастной мешалки 50 мм. Скорость вращения мешалки 300 об/мин [30].

Опыты проведены с различным содержанием железа и мышьяка в металле текущего производства. Результаты опытов (табл. 1.8) показали, что выход олова в съемы зависит от температуры окисления и имеет оптимум.

В табл. 1.8 приведены опыты по окислению суспензии примесей в съемы перемешиванием чернового олова на воздухе перед фильтрацией.

Таблица 1.8

Влияние окисление суспензии кристаллов съемов перемешиванием на воздухе

\begin{tabular}{|c|c|c|c|c|c|c|c|c|c|c|c|c|c|}
\hline \multirow[t]{2}{*}{$\begin{array}{l}\text { № } \\
\text { П/П }\end{array}$} & \multirow[t]{2}{*}{$\begin{array}{l}T, \\
{ }^{\circ} \mathrm{C}\end{array}$} & \multicolumn{2}{|c|}{$\begin{array}{c}\text { Ис- } \\
\text { ходное } \\
\text { олово, } \\
\%\end{array}$} & \multirow[t]{2}{*}{$\begin{array}{c}\mathrm{Fe} / \mathrm{As} \\
\text { исх. }\end{array}$} & \multirow[t]{2}{*}{$\begin{array}{c}B, \\
\text { мин }\end{array}$} & \multirow{2}{*}{$\begin{array}{c}\text { Вы- } \\
\text { ход, } \\
\%, \\
\text { съе- } \\
\text { мов }\end{array}$} & \multicolumn{2}{|c|}{$\begin{array}{c}\text { Анализ } \\
\text { съемов, } \\
\%\end{array}$} & \multirow[t]{2}{*}{$\mathrm{Sn} /(\mathrm{Fe}+\mathrm{As})$} & \multicolumn{2}{|c|}{$\begin{array}{c}\text { Рафини- } \\
\text { рованое } \\
\text { олово, \% }\end{array}$} & \multicolumn{2}{|c|}{$\begin{array}{c}\text { Процент } \\
\text { очистки }\end{array}$} \\
\hline & & $\mathrm{Fe}$ & As & & & & $\mathrm{Fe}$ & As & & $\mathrm{Fe}$ & As & $\begin{array}{l}\text { OT } \\
\mathrm{Fe}\end{array}$ & $\begin{array}{l}\text { OT } \\
\text { As }\end{array}$ \\
\hline 1 & 350 & 0,61 & 1,01 & 0,60 & 35 & 8,5 & 6,9 & 6,65 & 5,91 & 0,025 & 0,43 & 96,7 & 56,3 \\
\hline 2 & 400 & 0,46 & 0,76 & 0,61 & 30 & 5,4 & 6,86 & 6,2 & 5,48 & 0,09 & 0,45 & 81,2 & 44,4 \\
\hline 3 & 450 & 0,64 & 1,22 & 0,52 & 10 & 9,8 & 6,36 & 7,85 & 4,68 & 0,013 & 0,5 & 98,2 & 63,5 \\
\hline 4 & 450 & 0,79 & 0,96 & 0,82 & 30 & 5,3 & 13,7 & 7,1 & 2,84 & 0,066 & 0,62 & 92,2 & 39,3 \\
\hline 5 & 500 & 0,64 & 1,18 & 0,54 & 20 & 11,4 & 4,74 & 4,94 & 7,11 & 0,12 & 0,7 & 84,8 & 47,9 \\
\hline 6 & 550 & 0,39 & 1,63 & 0,24 & 15 & 9,6 & 3,29 & 9,43 & 5,91 & 0,073 & 0,8 & 82,1 & 56,3 \\
\hline
\end{tabular}

Примечание. Средняя загрузка 76 ке. В - длительность окисления, мин.

При более низких температурах происходит недостаточное окисление кристаллов и извлекаются интерметаллиды, в большей степени смоченные оловом. При относительно высокой температуре выход олова в съемы также увеличивается вследствие большего окисления расплавленного олова. Оптимальной температурой «осушки» кристаллов можно считать $400-450^{\circ} \mathrm{C}$ в течение 30 мин перемешивания [30]. Для снижения удельного выхода олова в съемы целесообразно прекращать фильтрацию после удаления основной массы железа и остаточное железо удалять одновременно с мышьяком. 


\subsection{6. Промышленные испытания центробежной фильтрации AsFe и сравнение с ииквационным рафинированием}

Промышленные испытания рафинирования чернового олова от железа и мышьяка проводились на аппарате ЦП-450 [31.3] и приведены в табл. 1.9.

Таблица 1.9

Результаты полупромышленных испытаний фильтрации олова от мышьяка с железом

\begin{tabular}{|c|c|c|c|c|c|c|c|c|c|c|c|}
\hline \multirow{2}{*}{$\begin{array}{c}\text { Плав- } \\
\text { ка }\end{array}$} & \multicolumn{2}{|c|}{$\begin{array}{c}\text { Исходный } \\
\text { металл }\end{array}$} & \multirow{2}{*}{$\begin{array}{c}\mathrm{Fe} / \mathrm{As}, \\
\mathrm{mol}\end{array}$} & \multirow{2}{*}{$\begin{array}{c}\text { Из } \\
\text { филь- } \\
\text { тра } \\
\text { As }\end{array}$} & \multicolumn{3}{|c|}{$\begin{array}{c}\text { Железистые } \\
\text { съемы }\end{array}$} & \multirow{2}{*}{$\begin{array}{c}\text { Выход } \\
\text { съе- } \\
\text { мов, } \\
\%\end{array}$} & \multirow{2}{*}{$\mathrm{Sn} /(\mathrm{Fe}+\mathrm{As})$} & \multicolumn{2}{|c|}{$\begin{array}{l}\text { Степень } \\
\text { очистки, \% }\end{array}$} \\
\hline & $\begin{array}{c}\mathrm{Fe} \\
\%\end{array}$ & $\begin{array}{c}\text { As, } \\
\%\end{array}$ & & & $\begin{array}{l}\mathrm{Sn}, \\
\%\end{array}$ & $\begin{array}{c}\mathrm{Fe} \\
\%\end{array}$ & $\begin{array}{c}\text { As, } \\
\%\end{array}$ & & & $\mathrm{Fe}$ & As \\
\hline 1 & 0,26 & 2,29 & 0,15 & 0,29 & 65,9 & 2,1 & 16,6 & 12,2 & 3,5 & 96,6 & 88,9 \\
\hline 2 & 0,88 & 2,24 & 0,53 & 0,3 & 54,9 & 7,4 & 16,7 & 11,8 & 2,3 & 99,0 & 88,2 \\
\hline 3 & 1,87 & 3,78 & 0,66 & 0,25 & 54,4 & 8,7 & 16,8 & 21,4 & 2,1 & 99,6 & 94,8 \\
\hline 4 & 2,00 & 2,69 & 1,00 & 0,27 & 52,3 & 12,5 & 15,4 & 16,0 & 1,9 & 99,6 & 91,6 \\
\hline 7 & 1,73 & 2,13 & 1,09 & 0,2 & 45,1 & 11,5 & 13,1 & 15,0 & 1,8 & 99,5 & 92,0 \\
\hline 5 & 2,04 & 2,23 & 1,22 & 0,24 & 48,8 & 13,9 & 13,9 & 14,6 & 1,8 & 99,6 & 90,8 \\
\hline 6 & 3,03 & 3,11 & 1,30 & 0,22 & 47,5 & 14,2 & 13,8 & 21,3 & 1,7 & 99,7 & 94,4 \\
\hline
\end{tabular}

Примечание. Средняя загрузка 17 m металла на плавку. Температура металла при фильтрации снижалась от 450 до $350^{\circ} \mathrm{C}$.

После фильтрации при температуре $450^{\circ} \mathrm{C}$ железа в олове остается $0,01 \%$, а мышьяка в среднем $0,2 \%$. Ниже приведенные результаты промышленных плавок (табл. 1.10) выявляют высокую погрешность подготовки исходного металла в оптимальном соотношении железа к мышьяку [18].

Среднее содержание в рафинированном металле - 0,014\% As; 0,009\% Fe.

В среднем удельный выход олова $\mathrm{Sn} /(\mathrm{Fe}+\mathrm{As})$ в съемы составил 4,02, что подтверждает проведенные опыты. Съемы при увлажнении не выделяли мышьяковистый водород. Статистическая обработка промышленных плавок подтвердила влияние снижения выхода олова в съемы с увеличением соотношения $\mathrm{Fe} / \mathrm{As}$ [22].

Как показывает рис. 1.20 при повышении в исходном металле соотношения (Fe/As)at до 0,5 в съемах соотношение (Fe/As $)_{d r}^{a t}$ увеличивается до 1,3. С дальнейшим повышением (Fe/As)at более 0,5 в съемах это соотношение снижается. Это объясняется удалением соединения $\mathrm{FeSn}_{2}$ одновременно с соединением FeAs. 
Таблица 1.10 Промышленные результаты рафинирования олова от железа и мышьяка центробежной фильтрацией

\begin{tabular}{|c|c|c|c|c|c|c|c|c|c|c|}
\hline \multirow{2}{*}{$\begin{array}{c}\text { Но- } \\
\text { мер } \\
\text { плав- } \\
\text { ки }\end{array}$} & \multicolumn{2}{|c|}{$\begin{array}{l}\text { Состав } \\
\text { металла }\end{array}$} & \multirow{2}{*}{$\frac{(\mathrm{Fe} / \mathrm{As}) \text { ic }}{\text { мол }}$} & \multicolumn{3}{|c|}{ Состав съемов, \% } & \multirow{2}{*}{$\begin{array}{c}(\mathrm{Fe} / \mathrm{As}) \mathrm{c}, \\
\text { мол }\end{array}$} & \multirow{2}{*}{$\begin{array}{c}\text { Удел. } \\
\text { вых. } \\
\text { Sn }\end{array}$} & \multicolumn{2}{|c|}{ Отраф. олово } \\
\hline & $\mathrm{Fe}, \%$ & As, $\%$ & & $\mathrm{Sn}$ & $\mathrm{Fe}$ & As & & & $\mathrm{Fe}, \%$ & As, $\%$ \\
\hline 1 & 0,17 & 0,11 & 2,09 & 69,3 & 13,3 & 3,9 & 4,56 & 4,04 & 0,005 & 0,06 \\
\hline 2 & 0,39 & 0,41 & 1,28 & 64,2 & 13,4 & 11,9 & 1,51 & 2,54 & 0,01 & 0,07 \\
\hline 3 & 0,64 & 0,34 & 2,48 & 72,3 & 14,3 & 6,64 & 2,89 & 3,45 & 0,005 & 0,05 \\
\hline 4 & 0,47 & 0,24 & 2,65 & 75 & 13,9 & 4,13 & 4,5 & 4,16 & 0,008 & 0,1 \\
\hline 5 & 0,14 & 0,34 & 0,57 & 61,7 & 15,1 & 15,76 & 1,28 & 2,00 & 0,012 & 0,2 \\
\hline 6 & 0,82 & 0,33 & 3,29 & 76,9 & 15,4 & 4,46 & 4,62 & 3,88 & 0,015 & 0,1 \\
\hline 7 & 0,41 & 0,07 & 8,29 & 84,8 & 14,4 & 1,64 & 11,7 & 5,29 & 0,005 & 0,02 \\
\hline 8 & 0,27 & 0,07 & 5,57 & 77,7 & 12 & 2,04 & 7,88 & 5,53 & 0,005 & 0,02 \\
\hline 9 & 0,43 & 0,06 & 10,1 & 81 & 13,4 & 0,21 & 85,5 & 5,95 & 0,01 & 0,05 \\
\hline 10 & 0,34 & 0,10 & 4,45 & 89 & 11,9 & 0,11 & 145 & 7,41 & 0,005 & 0,1 \\
\hline 11 & 0,25 & 0,04 & 8,68 & 84,6 & 8,78 & 1,05 & 11,2 & 8,61 & 0,01 & 0,01 \\
\hline 12 & 0,25 & 0,23 & 1,42 & 70,6 & 11,2 & 6,3 & 2,38 & 4,03 & 0,01 & 0,1 \\
\hline 13 & 0,43 & 0,42 & 1,36 & 73,1 & 12,3 & 9,44 & 1,74 & 3,37 & 0,01 & 0,1 \\
\hline
\end{tabular}

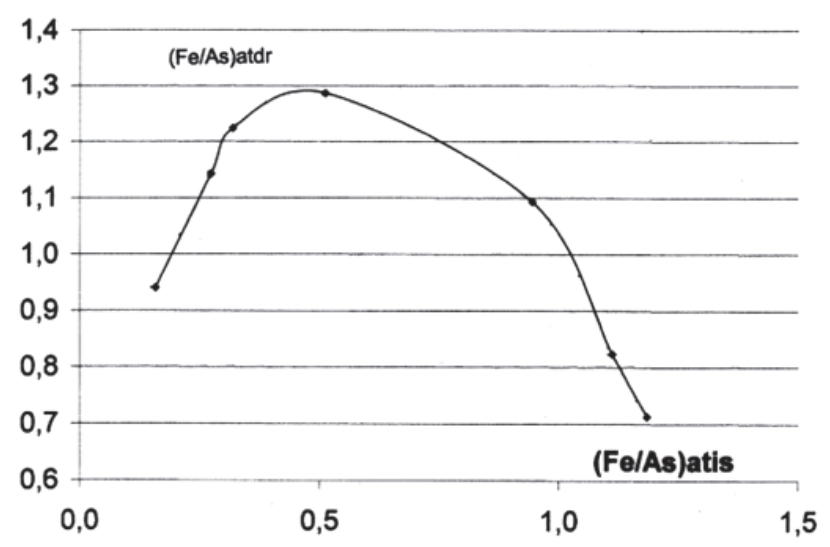

Рис. 1.20. Изменение соотношения (Fe/As)at в съемах от соотношения в исходном металле 
Содержание As в рафинированном олове с достаточно высокой достоверностью зависит от соотношения железа к мышьяку по уравнению:

$$
(\mathrm{As})_{\text {отр }}=0,3-0,066 \cdot(\mathrm{Fe} / \mathrm{As}) \text { с корреляцией } 0,87 .
$$

$\mathrm{C}$ увеличением соотношения в исходном олове ( $\mathrm{Fe} / \mathrm{As})$ при соотношении $0,46-0,65$, выход олова в съемы более резко снижается, а в целом снижается по уравнению:

$$
\mathrm{Sn} /(\mathrm{Fe}+\mathrm{As})=3,3-1,4 \cdot(\mathrm{Fe} / \mathrm{As})_{i s} \text { с корреляцией } 0,8 .
$$

Это согласуется с работой Брандт К. [32] по фильтрации олова через шлаковату. По его данным очистка олова от 0,8 до $0,08 \%$ As достигается фильтрацией соотношении $\mathrm{As} / \mathrm{Fe}=1$ и температуре $240-260^{\circ} \mathrm{C}$.

\subsection{7. Сравнение центробежной фильтрации олова с ликвационным рафинированием от железа и мышьяка}

Промышленные испытания подтвердили целесообразность частичного удаления железа при высокой температуре с последующей кристаллизацией мышьяка с железом охлаждением до температуры $300-350^{\circ} \mathrm{C}$. Это обеспечивает относительное снижение выхода олова в съемы в сравнении с огневым ликвационным рафинированием. В табл. 1.11 приведено сравнение центробежной фильтрации с ликвационным рафинированием [33].

Таблица 1.11 Сравнительные технико-экономические показатели очистки чернового олова от железа и мышьяка

\begin{tabular}{|l|c|c|}
\hline \multirow{2}{*}{\multicolumn{1}{|c|}{ Показатели }} & \multicolumn{2}{|c|}{ Технологические способы } \\
\cline { 2 - 3 } & Огневой & $\begin{array}{c}\text { Центробежная } \\
\text { фильтрация }\end{array}$ \\
\hline Извлечение олова в полупродукт & 91.0 & 96.78 \\
\hline Выход оборотных продуктов (съемов) & 12,3 & 6,9 \\
\hline Выход олова в оборотные продукты (съемы) & 8,3 & 3,7 \\
\hline Потерн олова & 0.7 & 0,62 \\
\hline
\end{tabular}

В работе [34] приведено сравнение показателей работы погружной центрифуги и заливного типа [4], а также сравнение с показателями огневого метода обработки чернового металла [8]. В табл. 1.12 сведены результаты сравнительных балансов огневого рафинирования чернового олова с высоким содержанием железа и мышьяка и рафинирования фильтрацией центрифугами погружного и заливного типов [34]. 
Таблица 1.12

Показатели огневого рафинирования чернового олова в сравнении с фильтрацией погружаемым фильтром и центрифугой заливного типа

\begin{tabular}{|c|c|c|c|c|}
\hline $\begin{array}{c}\text { Загружено чернового } \\
\text { олова, т }\end{array}$ & $\begin{array}{c}\text { Вес съемов, } \\
\text { т }\end{array}$ & $\begin{array}{c}\text { Выход олова } \\
\text { съемы, \% }\end{array}$ & $\begin{array}{c}\text { Расход кг/т } \\
\text { алюминия }\end{array}$ & $\begin{array}{c}\text { Продолжи- } \\
\text { тельность, ч }\end{array}$ \\
\hline \multicolumn{5}{|c|}{ Огневое рафинирование } \\
\hline 16160 & 7450 & 33,2 & 34,5 & 82 \\
\hline 16020 & 9780 & 33 & 41 & 96 \\
\hline \multicolumn{5}{|c|}{ Центрифуга заливного типа } \\
\hline 17994 & 5596 & 27,6 & 6,95 & 28 \\
\hline 15835 & 4606 & 20,7 & 5,2 & 28 \\
\hline 19967 & 8374 & 27,6 & 7,1 & 31 \\
\hline \multicolumn{5}{|c|}{ Центрифуга с погружаемым фильтром } \\
\hline 16300 & 3720 & 15,2 & 2,8 & 12 \\
\hline 13770 & 2720 & 12 & 4,9 & 8 \\
\hline 15186 & 2610 & 10,5 & 5,9 & 6 \\
\hline
\end{tabular}

Результаты баланса показали, что в сравнении с огневым ликвационным рафинированием при рафинировании погружной центрифугой отмечается снижение выхода съемов, уменьшение продолжительности цикла рафинирования, уменьшение выхода олова в съемы. Полученный металл при этом содержал $0,03 \%$ железа и $0,1 \%$ мышьяка при суммарном содержании их в исходном металле $3-5 \%$.

Отмечается основной вывод в том, что на первом этапе целесообразно удалять основную долю железа при температуре $550-450{ }^{\circ} \mathrm{C}$ в виде $\mathrm{FeSn}$ и FeAs, а оставшееся железо кристаллизовать As в FeAs охлаждением ниже $350^{\circ} \mathrm{C}$ с окислением кристаллов перемешиванием с последующей фильтрацией.

\section{4. Сопоставдение вариантов удаления остаточного мышьяка}

\subsection{1. Недостатки удаления мышьяка с алюминием}

Основным методом рафинирования олова от остатков мышьяка традиционно являлось связывание его алюминием в тугоплавкое интерметаллическое соединение AlAs. После удаления железа в черновое олово при температуре $500-550^{\circ} \mathrm{C}$ втворялся алюминий. Образующиеся интерметаллические соединения мышьяка с алюминием при этом ликвируют 
на поверхность в виде пены, которая после обработки хлористым аммонием превращается в сухие съемы [8]. С поверхности расплава олова вручную снимались алюминиево-мышьяковые съемы (рис. 1.21).

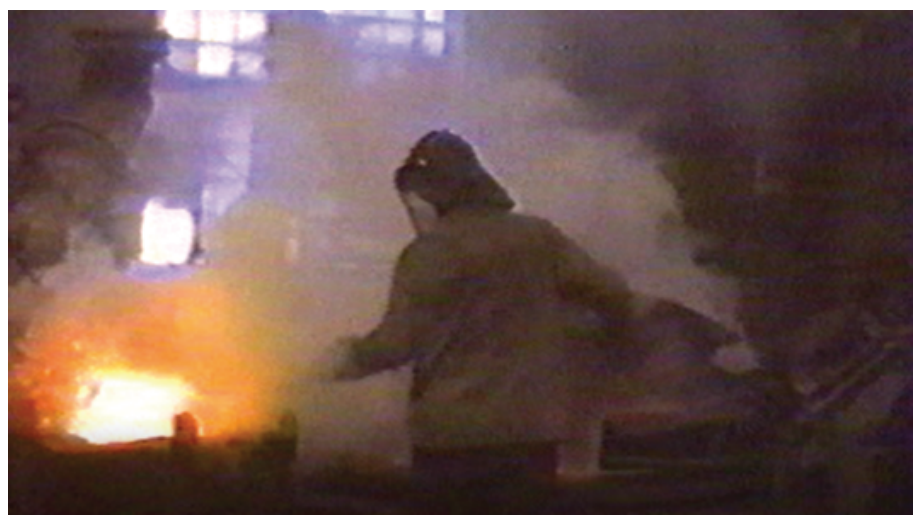

Рис. 1.21. Фото ручного снятия съемов

Обработка пены AlAs хлористым аммонием до сухих съемов и их отделение с поверхности металла сопровождается высоким газовыделением хлоридов аммония и алюминия. В дополнении к этому возникает необходимость избыток алюминия в олове также удалять хлористым аммонием. Для снижения расхода хлористого аммония предлагалось частичное окисление алюминиевой пены содой при $320-400^{\circ} \mathrm{C}$ [35]. Для связывания хлоридов в более прочные малолетучие соединения предлагалось пену обрабатывать вмешиванием окисей кальция, цинка [36]. Предлагалась замена летучего хлористого аммония на использование карналита [37]. Предложенный способ заключается в обработке расплавленного металла хлорсодержащим реагентом и отделение съемов. С целью снижения потерь олова расплав обрабатывают карналлитом в окислительной среде при $350-410^{\circ} \mathrm{C}$. По другому варианту пену соединений алюминия AsAl и SbAl предлагалось [38] обрабатывать углеродистым реагентом (гудроном) с последующим удалением съемов. С целью повышения извлечения $\mathrm{Sb}$ и $\mathrm{Sn}$ после вмешивания A1 расплав обрабатывают хлоридом щелочного металла, отделяют сурьмянистую пену от Sn и возвращают на рафинирование $\mathrm{Sn}$ от As, а затем Sn обрабатывают сульфатом аммония. Выделенные мышьяк-алюминиевые съемы и пыль содержат соединения мышьяка с алюминием AsAl. Taк как алюминий обладает амфотерными свойствами, то соединение AsAl с водой 
и с влагой воздуха реагирует с выделением ядовитого высокотоксичного газа - мышьяковистого водорода по реакции [39]:

$$
\mathrm{AsAl}+3 \mathrm{H}_{2} \mathrm{O}=\mathrm{Al}(\mathrm{OH})_{3}+\mathrm{AsH}_{3} .
$$

Опасность выделения мышьяковистого водорода создавала значительные затруднения в транспортировке, хранении и переработке съемов, пылей и делала невозможным их обжиг вместе с влажным концентратом. Возвращение съемов и пылей в восстановительную плавку приводило к циркуляции и накоплению мышьяка на переделе [40].

Все варианты совершенствования обработки алюминиевых соединений мышьяка снижают степень газовыделения, но все равно сохраняется потенциональная опасность в не предсказуемый момент выделения высокотоксичного мышьяковистого водорода. Для контроля состояния атмосферы газовая служба круглосуточно определяла содержание мышьяковистого водорода на этих операциях. Обслуживающий персонал обязан при себе иметь противогаз с коробкой БКФ. Напряженная психологическая обстановка выполнения операция вынуждает искать пути замены использования алюминия. Поэтому проведен поиск и сравнение металлов для связывания мышьяка в безопасные соединения.

\subsection{2. Сравнение способов связывания мышьяка в соединение.}

Для удаления остаточного мышьяка из олова его требуется связать в твердое нерастворимое соединение. В табл. 13.4 приведено сопоставление свойств, образующихся соединений металлов с мышьяком и оловом на основании диаграмм состояния [28].

Таблица 1.13

Сравнение свойств интерметаллических соединений As и $\mathrm{Sn}$

\begin{tabular}{|l|c|c|c|c|c|c|c|c|}
\hline \multirow{3}{*}{ Формулы } & \multicolumn{4}{|c|}{ Соединения Ме с As } & \multicolumn{3}{|c|}{ Соединения Ме с Sn } \\
\cline { 2 - 10 } & $\mathrm{Sn}$ & $\mathrm{Al}$ & $\mathrm{Fe}$ & $\mathrm{Cr}[3]$ & $\mathrm{Mn}$ & $\mathrm{Fe}$ & $\mathrm{Cr}$ & $\mathrm{Mn}$ \\
\cline { 2 - 10 } & $\mathrm{AsSn}$ & $\mathrm{AsAl}$ & $\mathrm{FeAs}$ & $\mathrm{CrAs}$ & $\mathrm{MnAs}$ & $\mathrm{FeSn}$ & $\mathrm{Cr}_{2} \mathrm{Sn}_{3}$ & $\mathrm{MnSn}_{2}$ \\
\hline$T,{ }^{\circ} \mathrm{C}$ плавления & 605 & 1760 & 1030 & 1000 & 1028 & 740 & & 710 \\
\hline$-\Delta H$, кДж/мол & $-15,02$ & -122 & $-17,6$ & -70 & -57 & -4 & & $-27,4$ \\
\hline$S$, Дж/мол & 49 & 60 & 97,8 & 40 & 77,1 & 9,1 & & 75,8 \\
\hline$\Delta G_{400}$ & $-10,6$ & -120 & $-41,2$ & $-56,8$ & $-63,4$ & $-6,1$ & & $-12,4$ \\
\hline
\end{tabular}


Для обеспечения всплытия примесей предпочтительно их связывать в тугоплавкие соединения снижающие их растворимость в олове. Кроме того, реагент - металл должен обладать растворимостью в олове и желательно без образования соединений с оловом. В табл. 1.14 приведены растворимость элементов в олове.

Таблица 1.14

Растворимость примесей в олове

\begin{tabular}{|c|c|c|c|c|c|c|}
\hline \multirow{2}{*}{$T,{ }^{\circ} \mathrm{C}$} & Вязкость Sn & \multicolumn{5}{|c|}{ Растворимость, вес. \% } \\
\cline { 2 - 7 } & МПасс & $\mathrm{Al}$ & $\mathrm{As}$ & $\mathrm{Fe}$ & $\mathrm{Cr}$ & $\mathrm{Mn}$ \\
\hline 240 & 1,45 & 0,4 & 0,21 & 0,001 & 0,005 & 0,2 \\
\hline 300 & 1,38 & 1,0 & 1,6 & 0,005 & 0,05 & 0,36 \\
\hline 350 & 1,32 & 2,4 & 2,7 & 0,015 & 0,1 & 0,71 \\
\hline 400 & 1,26 & 2,5 & 4,4 & 0,024 & 0,13 & 1,19 \\
\hline 450 & 1,2 & 3,9 & 6,9 & 0,08 & 0,165 & 1,9 \\
\hline 500 & 1,14 & 7,0 & 10 & 0,22 & 0,2 & 3,33 \\
\hline 600 & 1,02 & 32,9 & 38,6 & 0,6 & 0,43 & 10,4 \\
\hline 700 & 0,9 & & & 1,5 & 0,58 & 18,9 \\
\hline 800 & 0,78 & & & 2,8 & 0,8 & 29,9 \\
\hline
\end{tabular}

Алюминий хорошо растворяется в расплавленном олове без образования соединения, но взаимодействует с мышьяком с образованием прочного соединения $\mathrm{AsAl}\left(T_{\text {пл }}=1760^{\circ} \mathrm{C}\right)$. Перепад от температуры плавления до температуры расплава составляет $1100^{\circ} \mathrm{C}$. С химической точки зрения алюминий - идеальный металл для связывания мышьяка. Однако, потенциальная опасность отравления мышьяковистым водородом вынуждает искать альтернативные способы.

Железо с мышьяком образует четкие тугоплавкие соединения AsFe $\left(1030^{\circ} \mathrm{C}\right) ; \mathrm{As}_{2} \mathrm{Fe}\left(1020^{\circ} \mathrm{C}\right), \mathrm{AsFe}_{2}\left(930^{\circ} \mathrm{C}\right)$ и поэтому как описано ранее основная доля мышьяка успешно удаляется с железом. Однако, железо [28] в расплаве олова также образует фазы $\mathrm{FeSn}_{2}, \mathrm{FeSn}$ и поэтому необходим значительный избыток железа удаления мышьяка до требуемых содержаний. Это сопровождается значительным выходом олова в съемы.

О возможности образования интерметаллических соединений олово с хромом нет четких данных [28], но с мышьяком хром образует тугоплавкие соединения: $\mathrm{CrAs}\left(1000^{\circ} \mathrm{C}\right), \mathrm{Cr}_{4} \mathrm{As}_{3}\left(800^{\circ} \mathrm{C}\right), \mathrm{Cr}_{2} \mathrm{As}\left(907^{\circ} \mathrm{C}\right)$ [41]. Поэтому использование хрома для связывания мышьяка перспективно. 
Растворенный в олове марганец, с образованием соединения $\mathrm{Sn}_{2} \mathrm{Mn}$ $\left(710^{\circ} \mathrm{C}\right)$, образует также более тугоплавкое соединение с мышьяком AsMn $\left(1028^{\circ} \mathrm{C}\right)$. Марганец растворяется в олове до $20 \%$ вес при температуре более $720^{\circ} \mathrm{C}$. Это позволяет выплавлять лигатуру SnMn в рафинировочных котлах при более низкой температуре, чем лигатуру FeSn.

\subsection{3. Удаление остаточного мышьяка с железом}

Ранее показано, что железо связывает мышьяк в соединение FeAs, которое в виде съемов удаляется центробежной фильтрацией. Известно предложение удаления мышьяка из расплавленного олова путем вмешивания железо-оловянной лигатуры [42] с последующей обработкой при температуре $350-450{ }^{\circ} \mathrm{C}$ сульфидом железа и отделением съемов центробежной фильтрацией. Однако, для такого способа требуется предварительно сплавлять железо-оловянную лигатуру в индивидуальной чистой высокотемпературной (до $1000^{\circ} \mathrm{C}$ ) печи. Такие капитальные затраты препятствуют применению железистой лигатуры для связывания мышьяка. Кроме того, недостаток такого способа в том, что до связывания мышьяка в AsFe используется уже образовавшееся в лигатуре соединение $\mathrm{FeSn}_{2}$ и результат операции лимитируется соотношением концентраций соединений $\mathrm{FeAs}, \mathrm{FeSn}_{2}$.

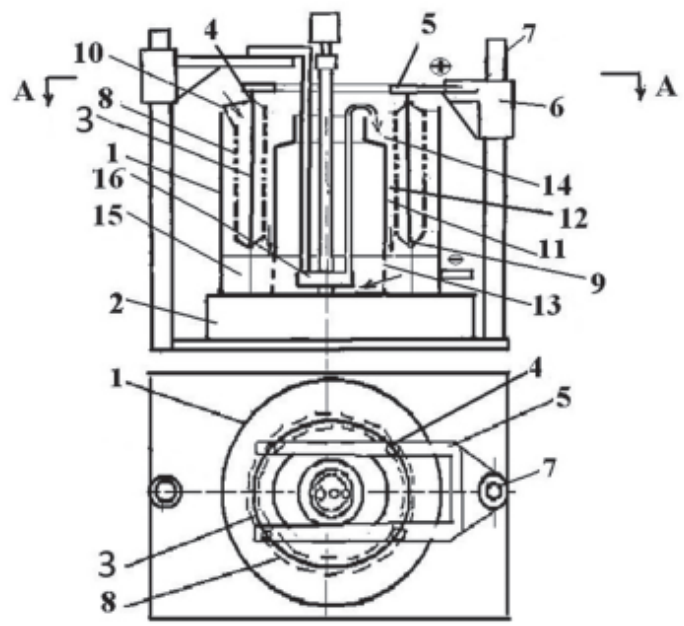

Рис. 1.22. Аппарат связывания мышьяка с железом электроэкстракцией.

Основные узлы: 1 - ванна; 3 - железный цилиндр; 8-диаррагма; 11 - ограничительная обечайка; 13 - перфорация; 14 - кольцевой карман; 16 - шестеренчатый насос 
Известен низкотемпературный способ электролитического растворения железа в олове и связывания в соединение FeAs электро-экстракцией [43]. Железо электролитически растворяют через диафрагму пропитанную электролитом и осаждают в олове, обеспечивая непосредственное связывание ионов железа с мышьяком. В ванну 1 электролизера (рис. 1.22) из нержавеющей стали, установленную на электропечь 2, заливается олово слоем 15, подлежащее рафинированию от мышьяка. Регулятором с термопарой поддерживают заданную температуру допустимую в интервале $300-400^{\circ} \mathrm{C}$. В ванну 1 погружается анодный цилиндр 3 из малоуглеродистого железа с заранее установленной на нем диафрагма 8 из кварцевой ткани КТ 11с8/3ТО герметизированная термостойким герметиком ВГО-1. Затем по оси цилиндра 3 погружается ограничительная обечайка 11. По оси обечайки 11 с помощью кронштейна погружается насос 16 [43].

При температуре олова $300-400^{\circ} \mathrm{C}$ включается насос 16 и расплавленное олово перекачивается со дна ванны 1 в карман 14 и поддерживает уровень олова в кармане 14. Избыточное поступление олова с насоса стекает через горловину во внутрь полости обечайки 11. Из заполненного кармана 14 олово стекает по зазору 12 между диафрагмой и обечайкой. Стекающее олово по зазору 12 внизу перетекает через перфорацию 13 обечайки 11 (показано стрелкой) в полость работы насоса 16, обеспечивая циркуляцию олова и поддерживая заданную температуру в зазоре 12 . Для пропитки ткани диафрагмы 8 в лоток 10 однократно заливается (показано стрелкой) расплавленный электролит состава вес. \%: калий хлористый 30-31; натрий хлористый 7-8; остальное железо двухлористое. Включается постоянный ток на электроды напряжением 3-10 В с плотностью тока $0,1-0,3 \mathrm{~A} / \mathrm{cm}^{2}$ и по мере пропитки диафрагмы сила тока повышается. Перфорация цилиндра 3 обеспечивает достаточную скорость пропитки диафрагм с двух сторон. Постоянный ток протекает с анодного цилиндра через диафрагму пропитанную указанным электролитом на стекающий слой олова служащий катодом. Под действием тока железо с анодного цилиндра ионизируется и катионы $\mathrm{Fe}^{+2}$ диффундируют по электролиту в капиллярах ткани и разряжаются на стекающую катодную пленку олова в зазоре 12. После разряда в олове ионов железа оно активно связывает растворенный мышьяк в нерастворимое соединение FeAs. Образующееся соединение FeAs, как более легкое, чем олово, остается на поверхности олова в зазоре между стенкой ванны 1 и стенкой обечайки 11. Так, как участок перфорации 13 ниже уровня олова 15 , то пена осадка не перетекает в полость обечайки 11. Таким образом, участок перфорации 13 является затвором предотвращения вовлечения уже образовавшихся соединений FeAs в циркуляцию в карман 14. Насос 16 
подает в карман 14 олово с растворенным мышьяком без твердого FeAs. По составу олова в кармане 14 контролируется остаточное содержание мышьяка. Процесс электролиза ведут до растворения железа в количестве необходимого для связывания мышьяка. По истечении необходимой длительности электролиза выкачивают олово из ванны в отдельный котел для отстоя и центробежной фильтрации олова от нерастворимых соединений FeAs. По мере откачивания олова из ванны уровень металла снижается ниже уровня перфорации и собранная пена опускается и перетекает в полость обечайки 11 для выкачивания в ванну для окисления с древесными опилками и центробежной фильтрации.

Испытания способа проводили на модернизированной ранее описанной электролизной установке [44]. В электрообогреваемую ванну опытного электролизера диаметром 16 см, высотой 10 см из нержавеющей стали вставлен анодный железный цилиндр диаметром $13 \mathrm{~cm}$, высотой $13 \mathrm{~cm}$ покрытый с двух сторон диафрагмой из кварцевой ткани КТ 11с8/3ТО. В анодной ванне наплавлено 4,9 кг олова с содержанием 0,3\% мышьяка. В зазор между диафрагмой и анодным цилиндром залито 220 г электролита, предварительно проплавленной смеси солей: калий хлористый $31 \%$; натрий хлористый 7\%; остальное железо двухлористое. Электролиз проводился при температуре $350^{\circ} \mathrm{C}$, при напряжении $4 \mathrm{~B}$, силе тока $8,0 \mathrm{~A}$, с периодическим отбором пробы из кармана на содержание железа и мышьяка. Содержание мышьяка в олове кармана через 30 мин $-0,2 \%$; через 60 мин - 0,11\%. Через 90 мин электролиза содержание мышьяка и железа составило $0,01 \%$ и напряжение отключено. Разбирали и зачищали узлы для взвешивания и анализа. Металл с пеной перемешивали при температуре $300^{\circ} \mathrm{C}$ в течение 30 мин с добавкой 20 г древесных опилок. После разложения опилок пена окислилась в сухие съемы. Выделенные съемы содержали $17,7 \% \mathrm{As}, 13,7 \% \mathrm{Fe}, 65,5 \% \mathrm{Sn}$. Относительные потери олова со съемами составили $\mathrm{Sn} /(\mathrm{As}+\mathrm{Fe})=2,08$. С увеличением силы тока и длительности снижается содержание мышьяка в олове и увеличивается производительность образования AsFe. C увеличением силы тока в съемах повышается относительное содержание железа Fe/As, что свидетельствует о начале образования $\mathrm{FeSn}_{2}$. Железо мышьяковистые съемы при смачивании водой безопасны, так как не выделяют мышьяковистый водород. По результатам опытной работы можно предполагать, что мышьяк связывается с электролитически осажденным железом до нерастворимого FeAs в момент разряда железа в олове без образования $\mathrm{FeSn}_{2}$. Тем самым снижается относительные потери олова со съемами $\mathrm{Sn} /(\mathrm{Fe}+\mathrm{As})$.

Опыты показали возможность связывания As с электро-выделяемым $\mathrm{Fe}$ при минимальной температуре в соединение FeAs не допуская образования 
$\mathrm{FeSn}_{2}$. Это обеспечивает снижения выхода олова в съемы [45]. Однако, способ не принят производством для периодического процесса. Для выполнения двух-трех операций в сутки длительностью по полчаса не целесообразно запускать электролизер. В производственных условиях может быть применено в условиях непрерывного процесса после установке электролизера на центрифуге и с экспресс анализом содержания мышьяка.

\subsection{4. Удаление остаточного мышьяка с хромом}

Ранее из сопоставление диаграмм показано, что при взаимодействии с мышьяком хром образует фазы $\mathrm{CrAs}, \mathrm{Cr}_{2} \mathrm{As}$, которые могут удалятся со съемами рафинирования. Хромовую лигатуру готовили сплавлением компонентов в лабораторной электропечи в течение 1 ч при $1300^{\circ} \mathrm{C}$ под слоем силикатного шлака [46]. Для проведения опытов использовали лигатуру с содержанием $6 \% \mathrm{Cr}$. В расплав олова, содержащем $2,77 \%$ As и навеской 100 г в каждом опыте добавлялась хромовая лигатура. Расплав перемешивался при температуе $450^{\circ} \mathrm{C}$ до растворения лигатуры и охлаждался. Центрифугирование проводили при температуре расплава $350^{\circ} \mathrm{C}$ на лабораторной центрифуге по методике [20]. Результаты опытов приведены в табл. 1.15.

Таблица 1.15

Результаты рафинирования олова от мышьяка при помощи хрома

\begin{tabular}{|c|c|c|c|c|c|c|}
\hline $\begin{array}{c}\text { Номер } \\
\text { опыта }\end{array}$ & $\begin{array}{c}\text { Расход } \\
(\mathrm{Cr} / \mathrm{As}) \text { at }\end{array}$ & $\begin{array}{c}\text { Выход, \%, } \\
\text { съемов }\end{array}$ & $\begin{array}{c}\text { Процент Аs } \\
\text { в съемах }\end{array}$ & $\begin{array}{c}\text { Процент } \\
\text { Аs в олове }\end{array}$ & $\begin{array}{c}\text { Степень } \\
\text { очистки, \% }\end{array}$ & $\begin{array}{c}\text { Выход } \\
\text { (Sn/As) с }\end{array}$ \\
\hline 1 & 0,4 & 11,4 & 10,5 & 1,1 & 52,1 & 8,2 \\
\hline 2 & 0,6 & 11,3 & 12,2 & 0,79 & 63,5 & 6,8 \\
\hline 3 & 0,9 & 10,9 & 15,4 & 0,28 & 85,6 & 5,1 \\
\hline 4 & 1,4 & 28,2 & 5,5 & 0,15 & 90,9 & 16,5 \\
\hline 5 & 1,8 & 30,4 & 4,8 & 0,05 & 96,9 & 19,0 \\
\hline 6 & 2,7 & 29,5 & 4,1 & 0,02 & 98,1 & 22,2 \\
\hline
\end{tabular}

Из табл. 1.15 видно, что с увеличением расхода хрома наблюдается повышенный переход олова в съемы и снижение содержания мышьяка в съемах. Это можно объяснить высокой смачивемостью соединения CrAs оловом.

Как показывает рис. 1.23 с увеличением расхода хрома, степень извлечения мышьяка в съемы вначале растет, а затем остается постоянной и оптимальный расход хрома составляет $(\mathrm{Cr} / \mathrm{As}) a t=1,3$. При повышении расхода хрома относительный выход олова в съемы резко возрастает $\mathrm{Sn} /(\mathrm{As}+\mathrm{Cr})>23[46]$. 


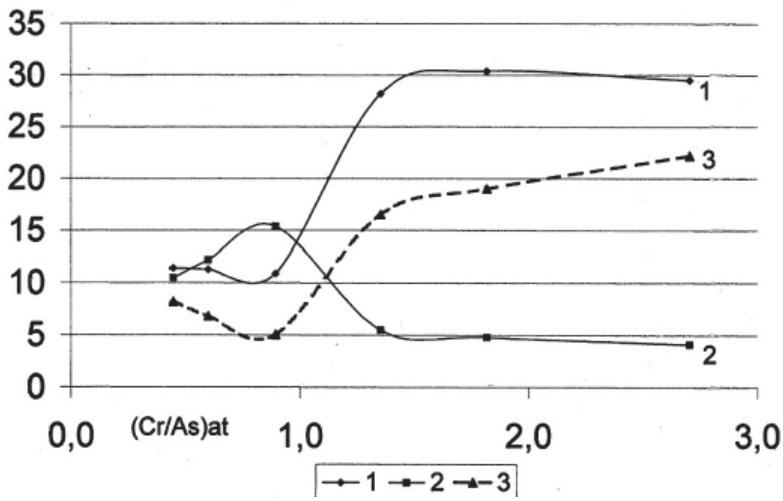

Рис. 1.23. Зависимость выхода олова в сбемы от расхода хрома. По абсииссе - соотношение (Cr/As)at в атомных долях; 1 - выход \% сбемов; 2 - содержание, \% Аs в сбемах;

3 - выход олова в съемы на единииу удаленного мышьяка $(\mathrm{Sn} / \mathrm{As}) \mathrm{c}$

Полученные мышьяк-хромовые съемы при увлажнении водой не выделяют мыщьяковистый водород по ранее указанной методике (раздел 1.3.1). Однако, остаются не ясны причины высокого выхода олова в съемы. Поэтому важно уточнить возможность образование соединения олова с хромом. Для этого провели сравнение состояния олова в лигатуре олово - хром и в съемах рафинирования олова от мышьяка с хромом при помощи метода ЯГР на ядре ${ }^{119} \mathrm{Sn}$. Мессбауэровские спек тры (рис. 1.24) измеряли при комнатной температуре на спектрометре MS-10K. В качестве источника использовали $\mathrm{Ba}^{119} \mathrm{SnO}$. Толщина поглотителей равнялась 58 кг вещества на $1 \mathrm{~cm}^{2}[46]$.

Для сравнения приведены также спектры $\beta$-Sn и титановой лигатуры, в которой линия фазы взаимодействия Ti-Sn отчетливо проявляется на фоне линии $\beta-\mathrm{Sn}$. Это обусловлено тем, что фаза взаимодействия $\mathrm{Ti}-\mathrm{Sn}$, по-видимому $\beta-\mathrm{Ti}_{6} \mathrm{Sn}_{5}$, имеет довольно высокое по сравнению с другими интерметаллидами олова квадрупольное расщепление $(\varepsilon=2,12 \pm 0,05 \mathrm{Mm} / \mathrm{c})$.

Мессбауэровский спектр для хромовой лигатуры (проба 3 рис. 1.24) также можно представить в виде суперпозиции линии $\beta$-Sn и квадрупольного дублета, который указывает на взаимодействие олова с хромом. Квадрупольный дублет имеет параметры, типичные для интерметаллидов олова: $\delta=2,28 \pm 0,03 \mathrm{~mm} / \mathrm{c}, \varepsilon=1,05 \pm 0,05 \mathrm{мm} / \mathrm{c}$. Мессбауэровские спектры съемов рафинирования (рис. 1.25) при невысоких добавках хрома (пробы 1-3) представляют собой одиночные линии, типичные для 
$\beta$-Sn. Это означает, что весь мышьяк в данных съемах находится в связанном с хромом состоянии. Для проб 4-6 наряду с линией $\beta-S n$ в спектрах появляется наплыв, типичный для фазы взаимодействия олова с хромом. Из сопоставления этого результата с рис. 1.25 [46] следует, что образование фазы Sn-Cr происходит в том случае, когда весь мышьяк практически извлечен и появляется избыточный хром, который и взаимодействует с оловом. Существование этого взаимодействия объясняет довольно высокую степень перехода олова в съемы для проб 4-6.

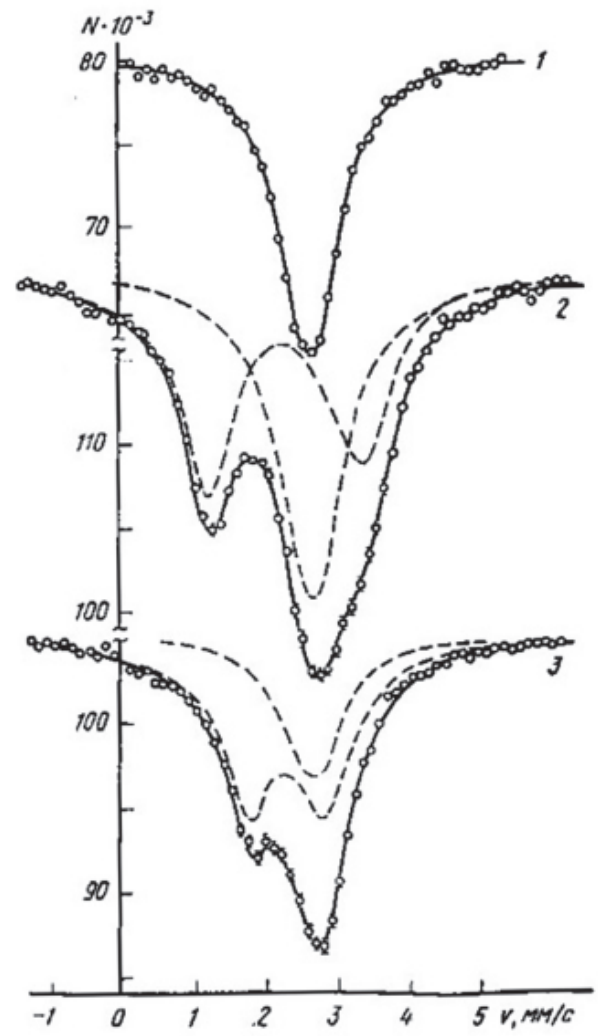

Рис. 1.24. Мессбауэровские спектры ${ }^{119} \mathrm{Sn} \beta$-Sn (1), титановой лигатуры (2) и хромовой лигатуры (3)

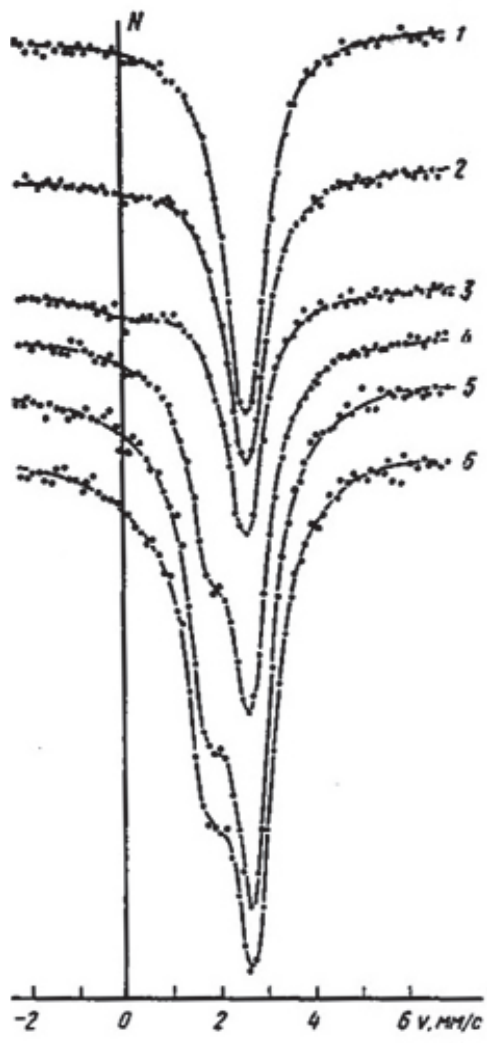

Рис. 1.25. Мессбауэровские спектры ${ }^{119} \mathrm{Sn}$ свемов рафинирования олова от мышьяка. Порядковый номер спектра соответствует порядковому номеру пробы в таблице 
Таким образом, исследования показывают, что кроме образования фаз в съемах вероятно происходит взаимодействие олова с хромом, чем можно объяснить повышенный выход олова в съемы. Препятствием более широким промышленным испытаниям составили большие трудности получения значительных объемов лигатуры. Для ее приготовления из крупных твердых кусков хрома требуется отдельная чистая печь для расплавления с перемешиванием при температуре $1000^{\circ} \mathrm{C}$. По табл. 1.14 видно, что более высокой растворимостью в олове, чем хром обладает марганец. Это значительно упрощает приготовление марганец-оловянной лигатуры при температурах $600-700^{\circ} \mathrm{C}$ в рафинировочных котлах.

\subsection{5. Удаление остаточного мышьяка с марганцем}

Проблема безопасного вывода остаточного мышьяка из олова решается связыванием мышьяка в тугоплавкое интерметаллическое соединение с марганцем. Марганец оказался более практичным с точки зрения доступности приготовления лигатуры для обеспечения дозировки. Для связывания растворенного остаточного мышьяка вместо алюминия использован марганец, который образует более тугоплавкие соединения с температурой плавления $\mathrm{Mn}_{2} \mathrm{As}\left(1029^{\circ} \mathrm{C}\right)$, MnAs $\left(925^{\circ} \mathrm{C}\right)$, чем мышьяк с оловом AsSn $\left(605^{\circ} \mathrm{C}\right)$ [47]. Однако марганец также образует тугоплавкие соединения с оловом $\mathrm{MnSn}_{2}\left(548^{\circ} \mathrm{C}\right), \mathrm{Mn}_{2} \mathrm{Sn}\left(897^{\circ} \mathrm{C}\right)$ и $\mathrm{Mn}_{3} \mathrm{Sn}\left(989^{\circ} \mathrm{C}\right)$ [48]. На основе этих сведений предложен способ удаления остаточного мышьяка связыванием его с марганцем [49]. При остаточном содержании мышьяка 0,04-0,2\% в расплавленное олово предложено вмешивать марганец-оловянную лигатуру при температуре $340-600^{\circ} \mathrm{C}$ с последующей центробежной фильтрацией расплава через сыпучий материал. Однако, оказалось для получения кондиционного содержания мышьяка в олове обнаруживается не постоянные результаты центробежной фильтрации, зависящие от расхода марганца и температуры ее вмешивания.

Для снижения выхода олова в съемы авторами [50] предложено вмешивать в металл марганцевый сплав до соотношения марганца к мышьяку 0,5-0,9 и затем вмешивать при температуре $280-320^{\circ} \mathrm{C}$ древесные опилки с последующей фильтрацией. Более устойчивые результаты получены по варианту, когда рафинируемый металл покрывают древесными опилками и вмешивают марганцевый сплав вначале до соотношения марганца к мышьяку $0,5-0,9$, а на конечной стадии рафинирования до соотношения $1,5-2,0$.

Для удаления остаточного мышьяка расплавленное олово загружалась $\mathrm{SnMn}$ лигатура с содержанием 6,5\% Mn при температуре $350^{\circ} \mathrm{C}$ до разных соотношений Mn/As (табл. 1.16). 
Таблица 1.16

Влияние расхода марганца на выход марганец-мышьяковой пены

\begin{tabular}{|c|c|c|c|c|c|c|c|c|c|}
\hline \multirow{2}{*}{$\begin{array}{c}\text { № } \\
\Pi / \Pi\end{array}$} & \multirow{2}{*}{$\begin{array}{c}\text { Процент } \\
\text { Аs в ме- } \\
\text { талле }\end{array}$} & \multicolumn{2}{|c|}{ Расход Mn } & \multirow{2}{*}{$\begin{array}{c}\text { Выход } \\
\text { пены, } \\
\%\end{array}$} & \multicolumn{2}{|c|}{$\begin{array}{c}\text { Содер- } \\
\text { жание } \\
\text { в пене, \% }\end{array}$} & \multirow{2}{*}{$\begin{array}{c}\text { Процент } \\
\text { очистки } \\
\text { от As }\end{array}$} & \multirow{2}{*}{$\begin{array}{c}\text { Процент } \\
\text { Аs в ме- } \\
\text { талле }\end{array}$} & \multirow{2}{*}{$\begin{array}{c}\text { Выход } \\
\mathrm{Sn} /(\mathrm{As}+\mathrm{Mn})\end{array}$} \\
\hline & & $\begin{array}{c}\text { весо- } \\
\text { вой }\end{array}$ & $\begin{array}{c}\text { атом- } \\
\text { ный }\end{array}$ & & As & $\mathrm{Mn}$ & & & \\
\hline 1 & 0,35 & 0,4 & 0,55 & 6,45 & 1,6 & 0,64 & 30,1 & 0,26 & 43,67 \\
\hline 2 & 0,33 & 0,6 & 0,82 & 5,7 & 2,9 & 1,76 & 52,3 & 0,16 & 20,27 \\
\hline 3 & 0,29 & 0,8 & 1,09 & 6,4 & 3,5 & 3,08 & 80,1 & 0,06 & 14,18 \\
\hline 4 & 0,3 & 1 & 1,36 & 7,21 & 3,8 & 3,86 & 95,2 & 0,015 & 12,07 \\
\hline 5 & 0,32 & 1,1 & 1,5 & 9,2 & 3,2 & 3,57 & 97,3 & 0,009 & 13,76 \\
\hline 6 & 0,31 & 1,3 & 1,77 & 10,9 & 2,7 & 3,46 & 98,9 & 0,004 & 15,34 \\
\hline 7 & 0,34 & 1,5 & 2,05 & 15,6 & 2 & 3,01 & 99,3 & 0,003 & 18,93 \\
\hline
\end{tabular}

Результаты в табл. 1.16 показывают, что кондиционное содержание мышьяка в отрафинированном олове достигается при весовом относительном расходе марганца $(\mathrm{Mn} / \mathrm{As})_{\text {ves }}=1$ или $(\mathrm{Mn} / \mathrm{As})_{\mathrm{at}}=1,36$. Но при таком расходе марганца мышьяковые соединения выделяются в виде плохо фильтруемой пены, но легко отделяются с поверхносного слоя.

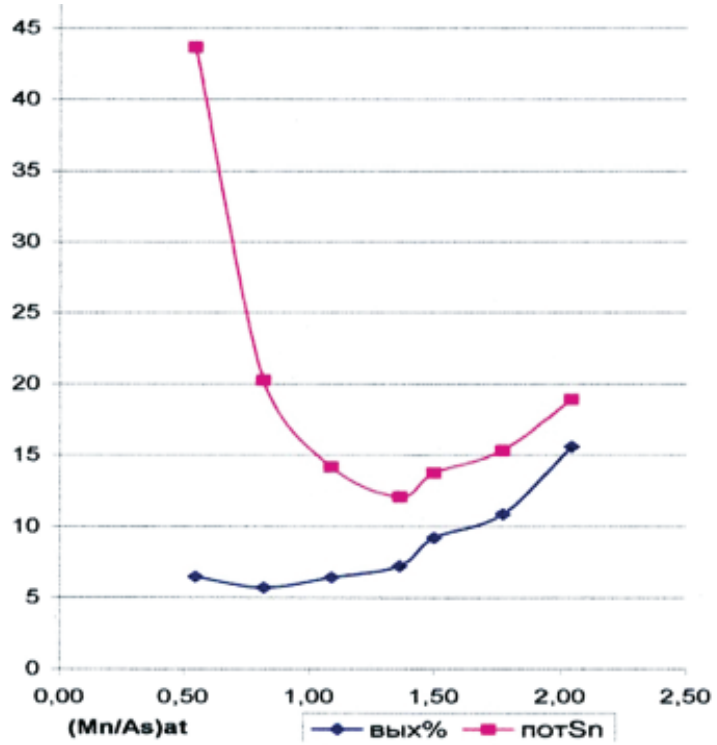

Рис. 1.26. Влияние удельного весового расхода марганца на выход пены 
Рисунок 1.26 показывает, что при удельном расходе на единицу содержания мышьяка $\mathrm{Mn} / \mathrm{As}>1$ выход пены увеличивается, но снижаются потери (выход по отношению удаляемому количеству мышьяка) олова с пеной. Это свидетельствует о том что мышьяк связан марганцем. В этих условиях пена лучше отделяется, чем фильтруется.

\section{5. Экстракция остатков мышьяка с марганцевой пеной}

\subsection{1. Условия образования пены соединений мышьяка с марганцем}

По мере охлаждения расплава растворимость соединений в олове снижается. Суспензия мелкодисперсных кристаллов MnAs и MnSn покрытых пленкой олова и на вид представляется как пена [26]. Пена соединений мышьяка растекается по поверхности расплавленного олова с матово коричневым оттенком [40; 19].

Табл ица 1.17

Результаты опытов по удалению мышьяка с марганцем в пену

\begin{tabular}{|c|c|c|c|c|}
\hline \multicolumn{2}{|r|}{$\begin{array}{c}\text { Содержание мышьяка, } \% \\
\text { истолле }\end{array}$} & $\begin{array}{c}\text { Степень удаления } \\
\text { мышьяка, \% } \\
\text { рования }\end{array}$ & $\begin{array}{c}\text { Расход марган- } \\
\text { ца, кг/т олова }\end{array}$ & Выход пены, \% \\
\hline 0,35 & 0,01 & 97,1 & 0,4 & 12,9 \\
\hline 0,2 & 0,01 & 96,5 & 4,0 & 7,6 \\
\hline 0,05 & $<0,01$ & 98,6 & 1,0 & 8,0 \\
\hline 0,35 & $<0,01$ & 99,8 & 6,4 & 10,3 \\
\hline 0,1 & $<0,01$ & 99,2 & 2,3 & 11,5 \\
\hline 0,35 & $<0,01$ & 99,8 & 8,6 & 19,5 \\
\hline 0,25 & $<0,01$ & 99,7 & 7,3 & 15,5 \\
\hline
\end{tabular}

При фильтрации центрифугой твердые соединения проходили сквозь щель фильтра, поэтому ее снимали вручную. Пену отделяли вручную и переплавляли отдельно при длительном перемешивании, Сквозной выход олова в марганец-мышьяковые съемы с доработкой пены составил $5,0-6,0 \%[19 ; 40]$.

На рис. 1.27 показано что при расходе марганца до соотношения в исходной загрузке (Mn/As)at $<1,4$ выход олова в пену связан с превышением мышьяка. В то время как при расходе марганца в соотношении в исходной загрузке (Mn/As)at > 1,4 выход олова в пену связан с превышением марганца. 


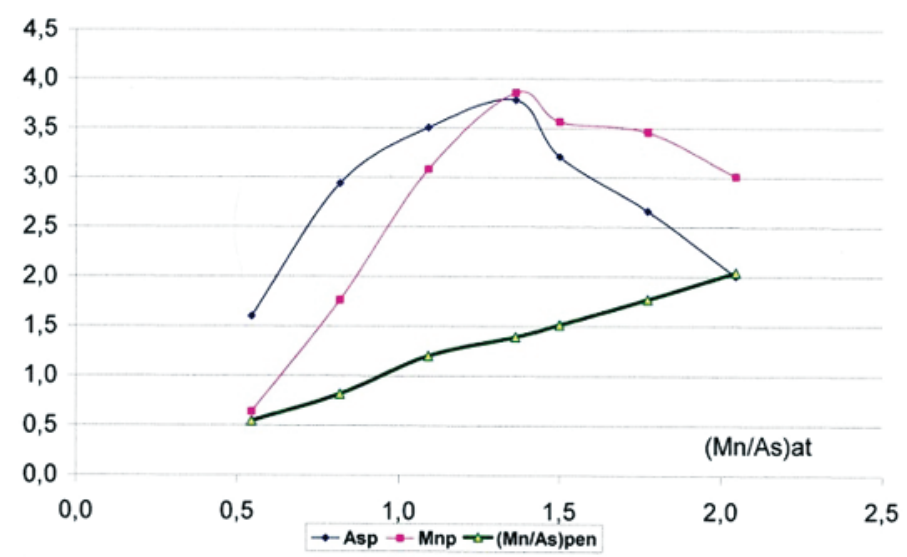

Рис. 1.27. Изменение состава пены с увеличением относительного расхода марганца.

По абсциссе - (Mn/As) at - расход марганиа относительно содержания мышьяка в атомных долях. По ординате - Asp-содержание As в пене; $M_{n p}-$ содержание Мп в пене; (Mn/As)pen - соотношение содержаний Мп и Аs в пене

\subsection{2. Термодинамика связывания мышьяка с марганцем}

Используя методику оценки термодинамических величин интерметаллических соединений [51; 52] и справочные данные [27] проведен сравнительный термодинамический расчет конкурирующих реакций связывания мышьяка в соединения. При остаточном содержании As $=0,1-0,3 \%$ в олове при температуре 400-300 $\mathrm{C}$ мышьяк в олове согласно диаграмме состояния системы находится в растворенном виде. После вмешивания в олово марганец-оловянной лигатуры мышьяк взаимодействует с марганцем с образованием малорастворимого соединения $\mathrm{MnAs}\left(925^{\circ} \mathrm{C}\right)$ по реакции:

$$
\mathrm{As}+\mathrm{MnSn}=\mathrm{MnAs}+\mathrm{Sn} \cdot \Delta Z_{400}^{\circ \mathrm{C}}=-32,5 \text { кДж/мол. }
$$

Активность As и Mn в расплаве олова снижена за счет равновесной обратимой реакции диссоциации соединений $\mathrm{AsSn}$ и $\mathrm{MnSn}_{2}$.

$$
\begin{aligned}
& \mathrm{AsSn}=\mathrm{As}+\mathrm{Sn} \cdot \Delta Z_{400}^{\circ \mathrm{C}}=-10,6 \text { кДж/ мол; } \\
& \mathrm{MnSn}=\mathrm{Mn}+\mathrm{Sn} \cdot \Delta Z_{400}^{\circ \mathrm{C}}=-8,4 \text { кДж/мол. }
\end{aligned}
$$

Как обычно при ликвационном рафинировании в съемы одновременно с примесями теряется и олово, причем в количестве, превышающем его теоретическое содержание в соединениях. Это объясняется тем, что кристаллы хорошо смачиваются оловом и покрыты пленкой олова. 
Термодинамические расчеты показывают, что марганец в 1,5 раза более эффективно окисляется, чем олово, покрывая интерметаллиды пленкой $\mathrm{MnO}$, мало смачиваемой оловом.

\subsection{3. Физико-химические исследования фаз мышьяка с марганцем}

Для получения информации о фазовом составе фильтростатков проведено сравнение мессбауэровских спектров опытных проб фильтрации олова. На рис. 1.28 представлены мессбауэровские спектры ${ }^{119} \mathrm{Sn}$, снятые на спектрометре MS-10K систочником $\mathrm{BaSnO}_{3}[18 ; 46]$.
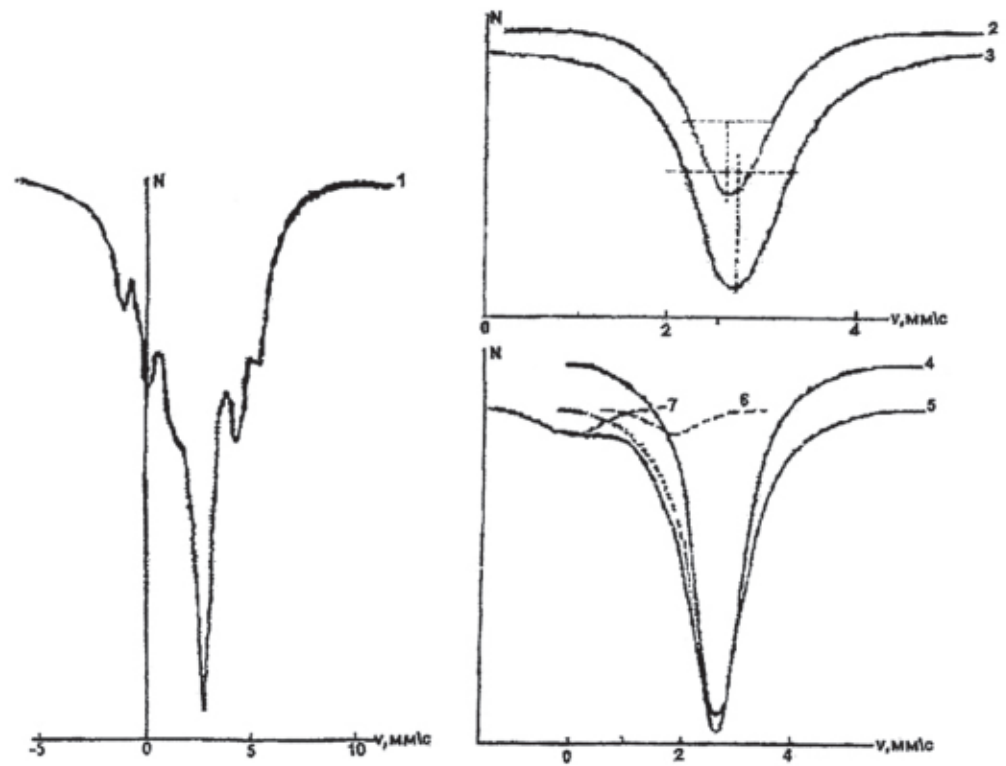

Рис. 1.28. Сравнение мессбауэровских спектров ${ }^{119} \mathrm{Sn}$ продуктов рафинирования олова. Спектр 1 - фазы $\mathrm{MnSn}_{2}$ в лигатуре (9,12\% Mn); спектр 2 - металлического олова $\beta$-Sn; спектр 3 сплава Sn - 7,3\% As; спектр 4 - очищенное олова; спектр 5 пены (6,5\% As, 6,1\%Mn); линия 6 расчетная огибающая соединение $\mathrm{MnSnAs}_{2}$; линия 7 расчетная огибающая соединение $\mathrm{SnO}_{2}$

Спектр 1 фазы $\mathrm{MnSn}_{2}$ в приготовленной марганец-оловянной лигатуре $(9,12 \% \mathrm{Mn})$. Спектр 3 показал, что линия сплава $\mathrm{Sn}-7,3 \%$ As сдвинута вправо, относительно линии $2-\beta-\mathrm{Sn}$ металла. Факт взаимодействия марганца и мышьяка определяется отсутствием линий $\mathrm{MnSn}_{2}$ (спектр 1) в спектре 5 пены и сдвига линии очищенного олова (спектр 4) 
(рис. 1.28). Сравнением мессбауэровских спектров ${ }^{119} \mathrm{Sn}$ спектров $\mathrm{MnSn-лигатуры} \mathrm{и} \mathrm{AsSn-сплава} \mathrm{со} \mathrm{спектром} \mathrm{пены} \mathrm{фильтрации} \mathrm{под-}$ тверждена реакция образования интерметаллического соединения MnAs. Небольшую ассиметрию мессбауэровского бета-Sn спектра 5 пены в сравнении со $\beta$-Sn спектром 4 можно связать с возможным существованием тройного соединения $\mathrm{MnSnAs}_{2}$ (огибающая пунктирная линия 6), относительное содержание которого может быть оценено около $1 \%$ [18]. Результаты в основном подтверждают протекание предполагаемой реакции (1.13).

Дополнительную информацию о фазовом составе технологических проб съемов рафинирования предполагалось получить ренгенофазовым анализом. Пробы опытов отбираемые для химического анализа растирали при $230^{\circ} \mathrm{C}$ и затем на приборе Frich до крупности - 50 мкм. Фазовый состав проб методом РФА определялся на дифрактометре ДРОН-3, с рентгеновской трубкой БСВ с медным анодом, в диапазоне углов 15-33 со скоростью съемки 2 г/мин. При расшифровке фазовых составов использовался банк Американской картотеки порошковых дифракционных стандартов JCPDS (Joint Commitee Powder Difraction Data Statisticfl). Спектры проб изображены на рис. 1.29.

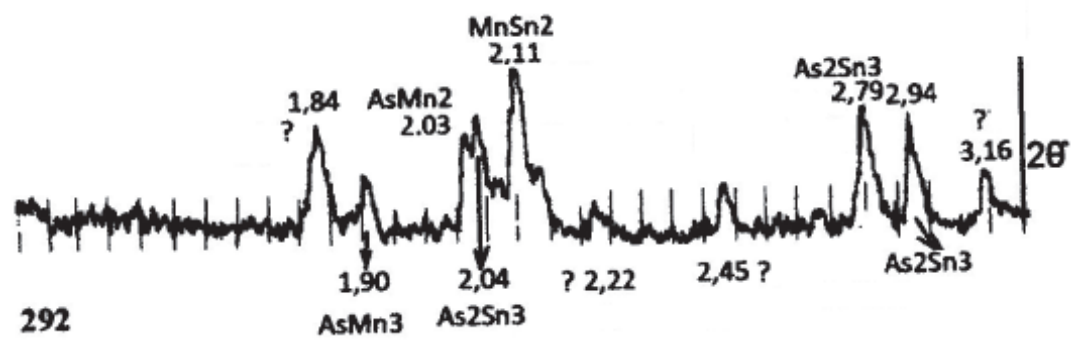

Рис. 1.29. Ренгенофазовые спектры фильтрованных мышьяково марганцовистых съемов

Приготовили пробу 292 отфильтрованных фильтростатков с высоким содержанием мышьяка и марганца. Химический анализ пробы 292 составил As - 31,82\%; Mn - 41,2\%, в том числе $5 \%$ MnO. В пробе с высоким содержанием мышьяка кроме фаз $\mathrm{As}_{2} \mathrm{Sn}_{3}$ и $\mathrm{MnSn}_{2}$ дополнительно обнаружена фазы AsMn $\mathrm{An} \mathrm{AsMn}_{3}$. В этой пробе также обнаружены не прореагировавшие фазы $\mathrm{As}_{2} \mathrm{Sn}_{3}$. Kроме того выявлены неопознанные линии, которые могут принадлежать возможной фазы AsMnSn. 


\subsection{4. Промышленные испытания отделения мышьяк-марганцовой пены}

Центробежная фильтрация при температуре $300-350^{\circ} \mathrm{C}$ сопровождается выбрасыванием пены сквозь щель фильтра, значительно снижая очистку от мышьяка. Поэтому пену кристаллов примесей $\mathrm{FeSn}_{2}$, MnAs отделяли вычерпыванием с поверхности металла и получали олово с содержанием мышьяка $0,01 \%$. Пену, выход которой составлял 15-18\%, отделяли вручную и переплавляли отдельно с добавкой исходного железистого чернового олова при длительном перемешивании для превращения пены в сухие съемы. Сквозной выход олова в съемы с доработкой пены составил 5,0-6,0\%. Отрафинированные съемы содержат 5-15\% железа, 5-25\% мышьяка, 40-70\% олова. Дозировка марганца (в виде лигатуры) зависит от содержания мышьяка в черновом олове (табл. 1.18).

Таблица 1.18 Дозировка марганца при рафинировании чернового олова с различным содержанием мышьяка

\begin{tabular}{|l|c|c|c|c|}
\hline Содержание мышьяка и черновом олове, $\%$ & до 0,1 & $0,1-0,3$ & $0,3-0,5$ & Более 0,5 \\
\hline Расход марганца (в лигатуре) кг на 1 кг мышьяка & 2,0 & 1,5 & 1,0 & 0,8 \\
\hline
\end{tabular}

Втворение оловянно-марганцевой лигатуры в черновое олово производится при температуре $320-350{ }^{\circ} \mathrm{C}$ при перемешивании пропеллерной мешалкой [34].

При промышленных испытаниях рафинирования олова кристаллы MnAs ликвируют на поверхность металла в виде пены. Очищенное олово выкачивается со дна погружным центробежным насосом. На пену оставленную в котле (1,5-2 т) загружается исходный металл с высоким содержанием железа для кристаллизации примесей и центробежной фильтрации рис. 1.30. Затем мешалка отключается и расплав отстаивается $30-60$ минут при температуре $300-320^{\circ} \mathrm{C}$. Центробежной фильтрацией отделяются кристаллы съемов. В отфильтрованное олово после отделения съемов содержат около $0,2 \%$ As и в него вмешивается марганцевая лигатура для повторения операции.

На рис. 1.30 показана схема рафинирования от мышьяка [26].

Однако, такой способ отделения пены не стал применяться на практике из за отсутствия экспрессного контроля качества олова по содержанию мышьяка, выкачиваемого из под пены. 


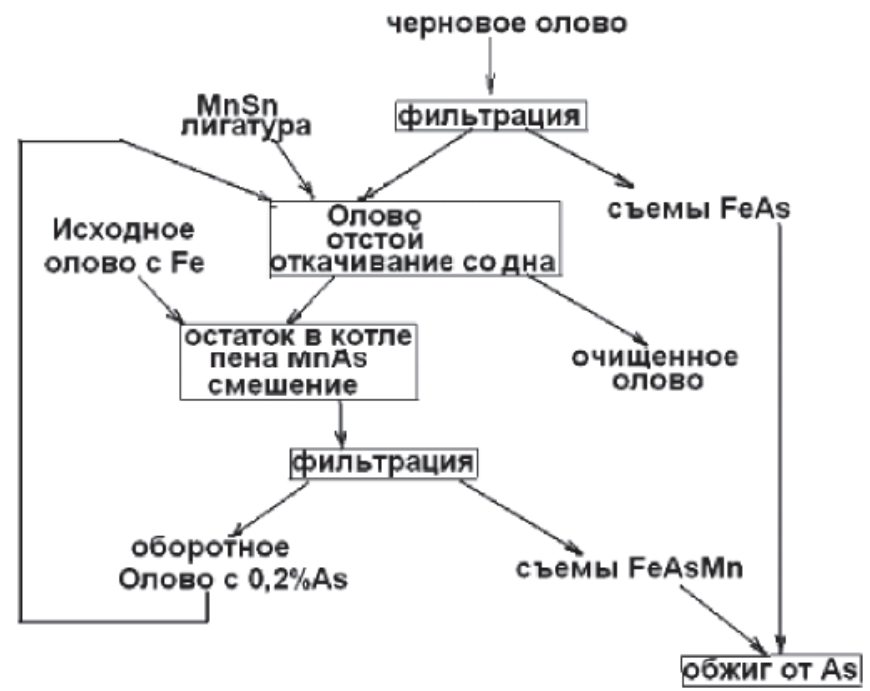

Рис. 1.30. Схема удаления As с Мп и исходным железистым оловом и обработкой пены

\subsection{5. Электромагнитное разделения распдава олова от пены}

Для совершенствования условий контроля отделения олова из под пены предложен МГД насос конструкции Г.И. Токарева [53]. Несколько доработанный аппарат включает обогреваемую ванну 1 (рис. 1.31, а) с оловом, на которую установлена центрифуга с погружаемым фильтром. В ванну 1 с оловом погружен кондукционный магнитогидродинамический (МГД) насос с оловопроводом 2 в защитном кожухе 3 , соединенный в верхней части с токопроводом 4 и отводящей трубкой 5. Оловопровод 2 выполнен в виде зигзагобразных участков 6 канала сечением $20 \times 10$ мм из листовой нержавеющей стали Х18Н9Т и в нижней части снабжен отводящим скосом 7. Кожух 3 снаружи электрически изолирован термостойкой стеклотканью 8 на термостойком герметике ВГО-1. Зазоры между участками каналов 6 оловопровода 2 заполнены вставками 9 треугольной формы из шамота. Оловопровод 2 выполнен из зигзагобразных наклонных под острым углом $35^{\circ}$ к оси участков 6 канала снабженном попеременно с каждой стороны С-образными магнитами 10 из термостойкого сплава KC-25. Нижний магнит установлен в устье всасывающего канала 11. В верхней части ванны 1 устанавливается центрифуга с фильтром 13, состоящим из двух соединенных конусообразных тарелей 
со всасывающими окнами 14 и с механизмами подъема, вращения и раскрывания фильтра [53.5].

Оловопровод 2, токопроводом 4 подключают к отрицательному полюсу источника постоянного тока. В зазоре каждого наклонного участка с помощью магнита создается магнитный поток 0,4 Тл. Постоянный ток силой 3-8 кА, напряжением 3 В от трансформатора ОСУ-80 проходит по олову в канале оловопровода 2 , в магнитном поле магнита 10 , пересекающем канал 6 оловопровода 2 (рис. 1.31).

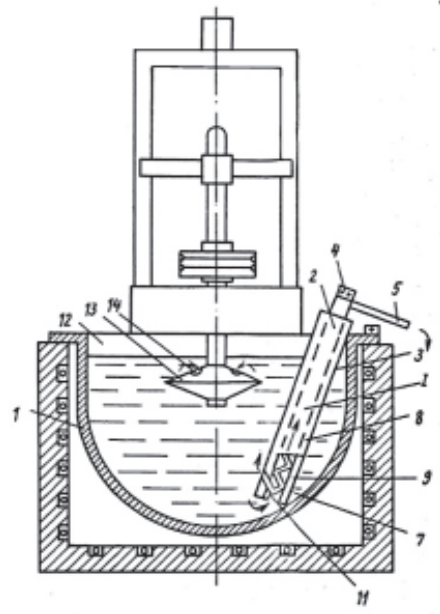

a
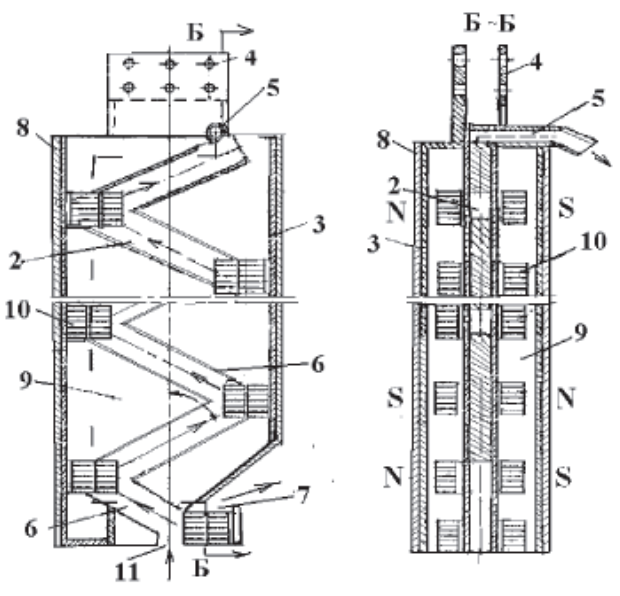

б

Рис. 31.5. Центрифуга в сочетании с МГД насосом. Основные узлы: 2 - оловопровод; 5 - сливная труба;

7- скос отводящий пену; 10 - магнит

Жидкое олово под действием электромагнитных сил, возникающих между полюсами магниты 10, проталкивается по основному каналу 2 и сливается по трубе 5 (показано стрелкой) на следующую операцию рафинирования. По мере отвода рафинированного металла с трубы 5 в ванну догружают исходный металл. В окно 12 периодически подают исходный рафинируемый металл. Примеси накапливаются в слое пены с повышенной концентрацией и укрупняются до легко фильтруемых размеров. Крупные кристаллы периодически собирают погружаемым вращающимся фильтром 13 промышленной центрифуги ЦП-450 со всасывающими окнами 14. Фильтр со съемами поднимают из расплава механизмом и выбрасывают съемы из фильтра. Во время испытания 
производительность замеряли взвешиванием количества слива металла за минуту с отбором пробы. Пробу металла с уровня 1 м глубины погружения насоса у скоса 7 отбирали трубкой щупом с краном, подобно химической пипетки. Металл и съемы анализировались на атомно-эмиссионном спектрометре с индуктивно связанной плазмой IRIS Intrepid компании INTERTECH Corporation. В табл. 1.19 приведены результаты испытаний аппарата при температуре $350^{\circ} \mathrm{C}$ [54].

Таблица 1.19

Результаты разделения олова от марганцевой пены МГД аппаратом

\begin{tabular}{|l|c|c|c|}
\hline \multicolumn{1}{|c|}{ Номер опыта } & 1 & 2 & 3 \\
\hline 1. Сила тока в канале, А & 2000 & 1000 & 500 \\
\hline 2. Производительность, кг/мин & 9,5 & 6,7 & 4,7 \\
\hline 3. Содержание Аs на сливе олова, \% & 0,07 & 0,03 & 0,01 \\
\hline 4. Степень очистки от Аs, \% & 50,2 & 77,9 & 92,9 \\
\hline 5. Содержание Аs, \%, на уровне 1 м у скоса 7 & 1,51 & 0,76 & 0,50 \\
\hline 6. Анализ Аs, \%, на уров 1 м с другой стороны от насоса & 0,37 & 0,36 & 0,36 \\
\hline 7. Степень концентрирования пены с МГД = п5/п6 & 4,1 & 2,1 & 1,4 \\
\hline
\end{tabular}

Примечание. Исходная загрузка 13 т олова с содержанием 0,15\% As. Расход лигатуры $(\mathrm{Sn}-6 \% \mathrm{Mn}) 350$ кг.

Испытания показали, что с увеличением силы тока увеличивается производительность слива и происходит повышение концентрации мышьяка в сливе олова. Сопоставление содержания мышьяка в слое металла на уровне 1 м у насоса и в противоположной стороне ванны показало повышение концентрации мышьяка. Причем, с повышением силы тока степень концентрирования мышьяка увеличивается. Это можно объяснить тем, что под действием магнитодинамических сил, возникающих за счет взаимодействия магнитного потока и электрического тока, менее электропроводные интерметаллические твердые соединения, чем олово отклоняются в отводящий скос 7, усиливая ликвацию примесей из ванны (показано стрелкой) на кристаллизацию [54]. Это способствует стабилизации откачиваемого олова по содержанию мышьяка. Это согласуется с результатами ранних исследований авторов [55], которые пропускали постоянный ток $50 \mathrm{~A} / \mathrm{cm}^{2}$ через черновое олово в магнитном поле 1 Тл и получали коэффициент разделения для мышьяка 10,3, а для железа 20,2. Отмечают что на разделение мешает перемешивание металла 
и стремились устранить перемешивание для получения экспериментальных данных. Вес съемов центробежной фильтрации после опыта 3 составил 270 кг. Состав съемов центробежной фильтрации, 5,1\% As; 6,9\% Mn; $86,0 \% \mathrm{Sn}$. Удельные потери со съемами $\mathrm{Sn} /(\mathrm{As}+\mathrm{Mn})=7,1$. В котле остается олово с марганец мышьяковой пеной для догрузки исходного олова. Проведенные исследования отделения олова из под мышьяк-марганцевой пены кондукционным магнитогидродинамическим насосом показали повышение в 1,4-4 раза концентрирование пены и обеспечение центробежной фильтрации съемов. Испытания выявили недостатки согласования регулирования расхода марганцевой лигатуры с подачей исходного металла. Недостаток аппарата в том, что каждая плавка требует монтаж узлов оборудования и последующим демонтажем. Выявленные недостатки и коррозия канала под действием тока не позволили промышленно использовать аппарат.

Однако результаты технологии разделения олова от мышьяково марганевой пены с помощью сочетания МГД насоса и аппарата центробежной фильтрации показывают их перспективность для условий организации непрерывного процесса. Ликвационное накопление пены путем отделения очищенного олова и пополнения исходного олова способствует кристаллизации соединений мышьяка для центробежной фильтрации.

\section{6. Фильтрация мышьяк-марганцовистой пены}

\subsection{1. Влияние марганцовистй пены на центробежную фильтрацию}

В предыдущем разделе показано, что для оптимизации показателей степени очистки олова и удельного выхода олова в съемы требуется повышенный расход марганца до соотношения $\mathrm{Mn} / \mathrm{As}=1,82$. Однако, избыток марганца ведет к образованию мелкодисперсного соединения $\mathrm{MnSn}_{2}$, которое с образуют пену. Малорастворимые кристаллы соединений мышьяка с марганцем всплывали на поверхность олова в виде слоя «пены». Пена не задерживается фильтром, снижая производительность рафинирования. При фильтрации олова кристаллы вначале в значительной доле проскакивали через щель фильтра, а затем в течение длительного вращения забивали щель накапливаемыми крупными кристаллами и фильтр становится малопроницаемым для жидкого олова. Поры уплотнены мелкими кристаллами. Полость фильтра остается незаполненной осадком, а олово в оставшемся объеме полости подвергается расслаиванию, окислению и пенообразованию. Это снижает производительность процесса рафинирования. 
Наблюдения показывают, что при забивании щели мелкими кристаллами и фильтр становится малопроницаем для жидкого олова, то при излишнем времени вращения фильтр начинает работать как отстойный.

Наблюдалось снижение проницаемости жидкое олово сквозь слой кристаллов и происходит отстойное расслаивание расплава на пену примесей и более очищенное олово. Таким образом, расслаивание твердых кристаллов в жидком олове при центробежной фильтрации приводит к дополнительному образованию пены и снижению производительности. Отфильтрованные съемы содержат повышенное содержание олова, снижая его извлечение.

\subsection{2. Исследования поведения MnAs в центробежном поле}

Для отделения образующихся малорастворимых кристаллов MnAs центробежной фильтрацией погружаемым фильтром представляет интерес поведение этих кристаллов в поле центробежных сил. Опыты по исследованию поведения кристаллов AsMn в жидком олове в центробежном поле проводили на лабораторной центрифуге с погружаемым фильтром (рис 1.1) [56]. Вместо тарельчатого фильтра на вал ротора ввинчивался контейнер (рис. 1.32) с кольцевой крышкой с образованием закрытой кольцевой полости.

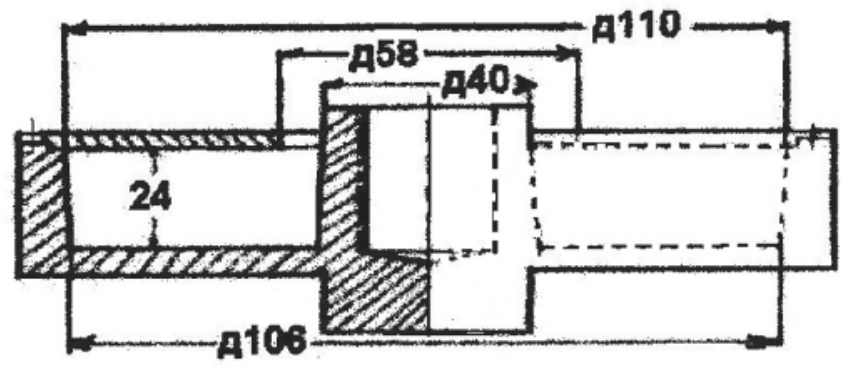

Рис. 1.32. Изложница для опыта затвердевания олова в центробежном поле

В олово с содержанием $1,1 \%$ мышьяка при температуре $450{ }^{\circ} \mathrm{C}$ вмешивали $8 \%$ марганец-оловянную лигатуру до содержания $1,5 \% \mathrm{Mn}$ и перемешивали металл в ванне. Контейнер погружался на 20 мин в расплавленное олово с температурой $450^{\circ} \mathrm{C}$ для заполнения контейнера. Двигателем постоянного тока контейнер в расплаве приводился во вращение 1500 об/мин в течение 10 мин, поднимали над поверхностью 
расплава, сохраняя вращение на 60 с, необходимое для затвердевания металла в контейнере. Вращение контейнера останавливали, свинчивали его с вала ротора. Открывали герметичную крышку с контейнера для извлечения цилиндрического слитка. На токарном станке обтачивали половину толщины слиток на пробы согласно рис. 1.33. Со второй половины слитка изготавливали шлифы. В табл. 1.20 приведены послойные анализы зон удаленных на разных расстояниях от оси [56].
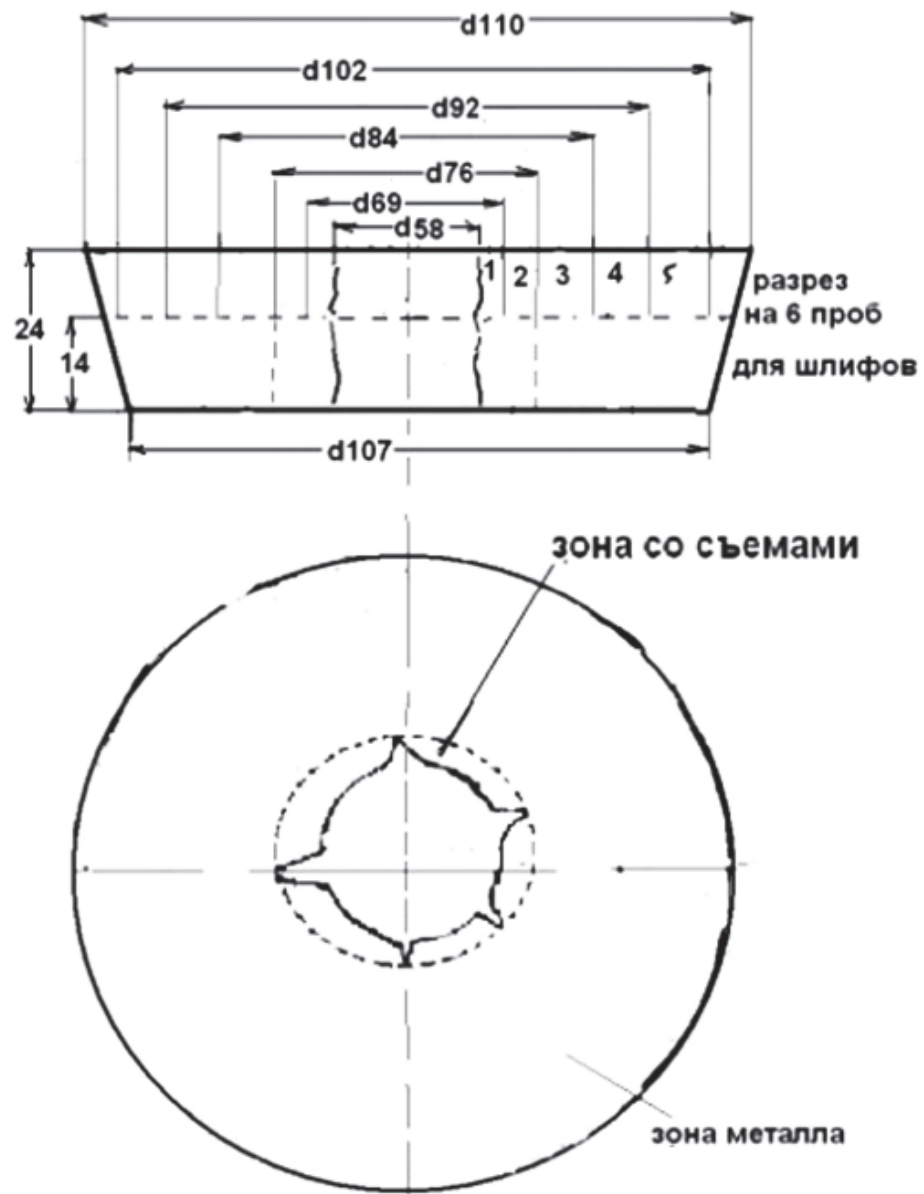

Рис. 1.33. Схема разреза слитка опыта затвердевания олова в центробежном поле 
Таблица 1.20

Результаты опыта по распределению примесей в жидком олове в центробежном поле

\begin{tabular}{|c|c|c|c|c|c|c|c|c|c|}
\hline \multirow{3}{*}{$\begin{array}{c}\text { Номер } \\
\text { проб } \\
\text { сечения }\end{array}$} & \multicolumn{2}{|c|}{ Диаметр } & \multirow{3}{*}{$\begin{array}{l}R, \text { см, } \\
\text { от } \\
\text { центра }\end{array}$} & \multicolumn{2}{|c|}{ Анализ, \% } & \multirow{3}{*}{$(\mathrm{Mn} / \mathrm{As})_{a t}$} & \multirow{2}{*}{\multicolumn{2}{|c|}{$\begin{array}{c}\text { Весовая доля } \\
\text { распределения }\end{array}$}} & \multirow{3}{*}{$\begin{array}{l}\text { Скорость } \\
\text { АsМn, } \\
\text { Г/см'мин }\end{array}$} \\
\hline & мин, & мах, & & \multirow{2}{*}{ As } & \multirow{2}{*}{$\mathrm{Mn}$} & & & & \\
\hline & MM & MM & & & & & As & $\mathrm{Mn}$ & \\
\hline исходн. & 58 & 110 & & 1,1 & 1,5 & 1,86 & & & \\
\hline 1 & 58 & 69 & 3,18 & 2,53 & 4,74 & 2,56 & & & \\
\hline 2 & 69 & 76 & 3,63 & 2,22 & 3,72 & 2,29 & 16,9 & 21,3 & $-0,015$ \\
\hline 3 & 76 & 84 & 4 & 1,59 & 2,65 & 2,27 & 24,8 & 29,1 & $-0,013$ \\
\hline 4 & 84 & 92 & 4,4 & 1,14 & 1,53 & 1,83 & 19,6 & 18,5 & $-0,008$ \\
\hline 5 & 92 & 102 & 4,85 & 0,79 & 0,55 & 0,95 & 18,7 & 9,2 & $-0,009$ \\
\hline 6 & 102 & 110 & 5,3 & 0,18 & 0,05 & 0,4 & 3,1 & 0,6 & \\
\hline
\end{tabular}

В соответствии с анализом образцов стружки зон рассчитывали стехиометрическую долю марганца связанного с мышьяком в соединение AsMn c температурой затвердевания $935^{\circ} \mathrm{C}$. Марганец не связанный в кристаллы AsMn считали связанным с оловом в растворенные кластеры $\mathrm{MnSn}_{2}$ с температурой затвердевания $548^{\circ} \mathrm{C}$ [56].

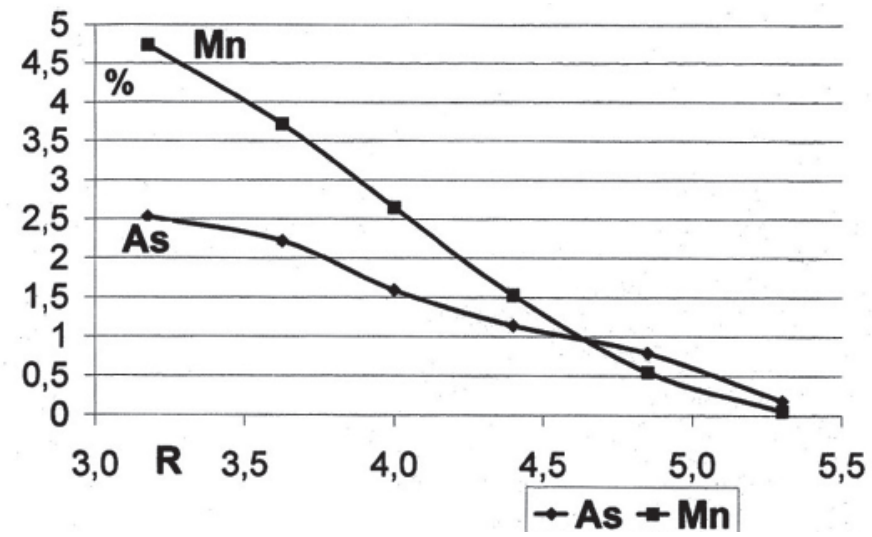

Рис. 1.34. Изменение содержания примесей в олове в центробежном поле

Рисунок 1.34 показывает, что As и Мn ликвируют к оси вращения пропорционально в одинаковой степени. 
С удалением от центра содержание элементов снижается по уравнениям:

$$
\begin{gathered}
\text { As } \%=6,14-1,12 \cdot R \text { с корреляцией } 0,99 ; \\
\text { Mn } \%=12-2,31 \cdot R \text { с корреляцией } 0,98 .
\end{gathered}
$$

В соответствии с этим повышается степень концентрирования элементов в зоне у оси в сравнении с исходным содержанием по уравнениям.

$$
\begin{gathered}
K_{m n}=8-1,54 \cdot R \text { с корреляцией } 0,98 ; \\
K_{a s}=5,6-1,02 \cdot R \text { с корреляцией } 0,99 .
\end{gathered}
$$

На образце слитка (рис. 1.33) видно кольца 1, 2 у оси в виде пористой пены с неоднородной поверхностью.

В условиях проведенного опыта частицы кристаллов AsMn при вращении со скоростью $n=1500$ об/мин контейнера с радиусом слоя $R$ от оси испытывает ускорение центробежных сил:

$$
J=\omega^{2} \cdot R \cdot J=709,9 \mathrm{M} / \mathrm{c}^{2},
$$

где $\omega-$ угловая скорость вращения $\omega=2 \cdot \pi \cdot n / 60$, рад/с; $R-$ радиус вращения, м.

При этом расплав испытывает фактор разделения Ф, представляющий собой отношение ускорения центробежной силы к ускорению силы тяжести:

$$
\Phi=\omega^{2} \cdot R / g,
$$

где $g=9,81$ кг $/ \mathrm{c}^{2}-$ ускорение силы тяжести.

Осаждение частиц под действием центробежной силы описывается связью между критериями подобия [57]:

$$
\mathrm{Ar}_{\Perp} \cdot \mathrm{Ly}_{ц}=\mathrm{Re}^{3},
$$

где Re - критерий Рейнольдца; $\mathrm{Ly}_{\text {ц }}$ - центробежный критерий Лященко; $\mathrm{Ar}_{\text {ц }}$ - центробежный критерий Архимеда,

$$
\operatorname{Ar}_{\mathrm{u}}=\frac{j \cdot \rho_{\mathrm{c}} \cdot\left(\rho_{t}-\rho_{\mathrm{c}}\right) d_{t}^{3}}{\mu_{\mathrm{c}}^{2}},
$$

здесь $\mathrm{Ar}_{\Perp}$ - определен для движущейся частицы AsMn при движении в олове плотностью $\rho_{\mathrm{c}}=6,83 \mathrm{\kappa г} / \mathrm{M}^{3}$ и динамической вязкостью $\mu_{\mathrm{c}}=1,14 \mathrm{c} / \mathrm{M}^{2}$.

После определения критория Архимеда $\mathrm{Ar}_{\text {ц }}=3,06 \cdot 10^{-6}$ согласно того, что рассчитанный критерий $\mathrm{Ar}_{\text {ц }}<3,6$, то в соответствии [57] справедлива формула определения скорости частиц:

$$
w_{o c}=\frac{d_{t}^{2} \cdot\left(\rho_{t}-\rho_{c}\right) \cdot J}{18 \cdot \mu_{c}}, \mathrm{M} / \mathrm{c},
$$


После определения $J$ каждого удаленного от оси слоя определялась скорость осаждения частицы, изменения их рассчитанной концентрации. Расчетная скорость ликвации более близко приближается к опытным данным для частиц с периферии с диаметром 0,8 мм, а у центра с диаметром 1,2 мм. Недостаточное укрупнение частиц объясняется ранее указанными упрощениями и согласуется с мнением авторов [58] о погрешности расчетов осаждения в расплаве металлов. Однако опыт показал, что в поле центробежных сил кристаллы фазы AsMn ликвируют к центру пропорционально с ликвацией $\mathrm{MnSn}_{2}$. Это можно объяснить тем что кристаллы $\mathrm{MnSn}_{2}$ и AsMn оттесняются к центру более тяжелыми кластерами жидкого олова. Пропорциональное их изменение вызывает предположение о ликвации в виде тройного соединения $\mathrm{AsMn}_{2} \mathrm{Sn}_{2}$.

\subsection{3. Возможности отстойно фильтрующих центрифуг}

При фильтрации расплавов неоднократно уделялось внимание изменению конструкции фильтра для отстойного уплотнения суспензии. Известны работы [59] по отделению отстоявшейся жидкой фазы.

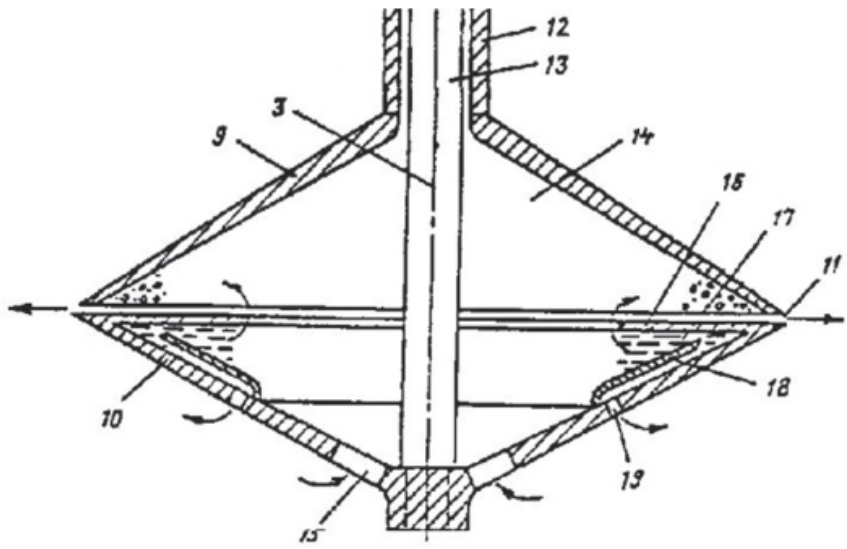

Рис. 1.35. Фильтр отстойно фильтрующий.

Основные узлы: 9, 10 - тарели; 11 - фильтрующая щель; 15 - окно забора;

16 - кольцеобразная крышка; 17 - отстойная полость; 18 - конусная перегородка;

19 - отверстие сброса отстоя

Для этого одна из тарелей фильтра (рис. 1.1) снабжена кольцеобразной крышкой (рис. 1.35) [60], размещенной по большему основанию конуса тарели с образованием кольцевой отстойной полости, конусообразной перегородкой, разделяющей кольцевую отстойную полость 
и образующей в ней у большего своего основания сифон, а меньшим основанием герметично соединенной с конусообразной тарелью, и в зоне соединения перегородки с тарелью в последней выполнены выходные отверстия каналов сифона для отвода металла. Причем, внутренний диаметр кольцеобразной крышки равен диаметру окружности, по которой выполнены выходные отверстия каналов сифона [59].

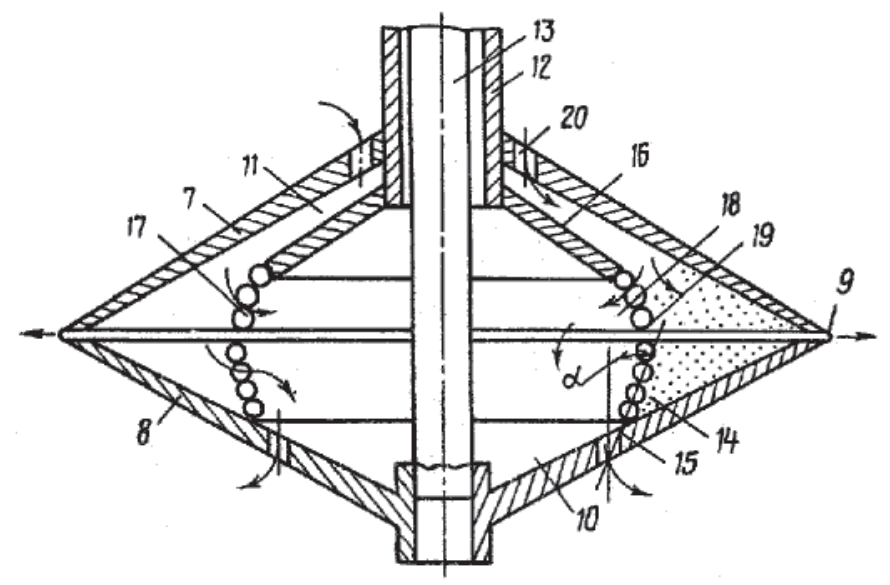

Рис. 1.36. Фильтр отстойно фильтрующий.

Основные узлы: 9 - фильтрующая щель; 14 - полость осадка; 15 - окно сброса отстоя; 17 - витки спирали; 18 - внутренние щели

Под действием центробежных сил жидкая фаза, имеющая больший удельный вес, прижимается к периферии отстойной полости 17 , а более легкие твердые кристаллы интерметаллических примесей накапливаются в отстойной полости 17 ближе к центру. После расслаивания кристаллов примесей жидкая фаза выдавливается по каналу сифона, образованному стенкой тарели 10 и конусной перегородкой 18 и через отверстие 19 выбрасывается (показано стрелкой) в котел. По мере накопления в кольцевой отстойной полости 17 твердые кристаллы в виде суспензии выдавливаются (показано стрелкой) через кольцеобразную крышку 16 в зазор между тарелью 9 и крышкой 16 для фильтрации. Жидкость из суспензии продавливается под действием центробежных сил через фильтрующую щель 11 (показано стрелкой) в котел. Твердые кристаллы накапливаются в виде осадка в зазоре между крышкой 16 и тарелью 9. Периодически по мере накопления осадка фильтр приподнимается над уровнем расплава до уровня разгрузки осадка. Тарели 9 и 10 фильтра разжимаются и осадок 
под действием центробежных сил выбрасывается в зону разгрузки. Это, по мнению авторов, позволило повысить производительность фильтра. Однако в сравнении с наружной щелью внутренняя щель имеет меньшую поверхность и меньшее центробежное ускорение. Из рассмотренных в монографии [60] отстойных фильтров для фильтрации тяжелой жидкой фазы от легких кристаллов MnAs больше подходит фильтр [61]. С целью повышения производительности тонкодисперсных суспензий рафинируемого расплава предлагалось (рис. 1.36) внутренние конусы каждой из тарелей выполнить в виде спирали с углом наклона образующей конуса к оси вращения фильтра 10-30, а радиус расстояния от выпускных окон до оси вращения фильтра в 1,3-2,2 раза больше радиуса расстояния от заборных окон до этой оси [61].

Вначале под действием центробежных сил жидкая фаза продавливается через фильтрующую щель 9, а мелкие твердые кристаллы интерметаллических примесей накапливаются в полости 14. После накопления осадка кристаллов примесей в полости 14 забившаяся щель 9 становится непроницаемой и жидкая фаза отстаивается от твердых кристаллов и выдавливается через внутренние фильтрующие щели 18, образованные витками спиралей 17 , и щель 19 между конусами спиралей, и далее через окно 15 выбрасывается (показано стрелкой) в котел-ванну 1. Описанные отстойно-фильтрующие центрифуги принципиально обеспечивают отстой и концентрирование пены, но их производительность ниже, чем ликвационный отстой пены в котле. Кроме того смена фильтра в центрифуге редкое плановое мероприятие. Поэтому в производственных условиях для упрощения организации производственного процесса имел предпочтение окисление пены до сухих съемов.

\section{7. Удаление остаточного мышьяка фидьтрацией окисленной мышьяк-марганцевой пены}

Вмешивание в пену зернистого материала в виде песка или грануллированного шлака обеспечивает заполняемость полости фильтра и стабилизирует производительность фильтра. Однако, эти материалы смачиваются пленкой олова, повышают выход веса съемов и содержание олова в съемах. Такие инертные компоненты ведут к дополнительным расходам переработке съемов.

Окисление пены позволяет задерживать примеси в щели фильтра, но снижает циркуляцию расплава через фильтр, снижает заполняемость полости фильтра и его производительность. Для снижения снижения расхода марганца предложено [62] перед центробежной фильтрацией в марганец-мышьяковую пену вмешивать исходное черновое олово, 
содержащее железо, и выдерживать в течение 0,5-2 ч при температуре $360-450^{\circ} \mathrm{C}$ для кристаллизации AsFe и AsMn. Однако, приготовление железистого олова более трудоемкое, чем марганцовистой лигатуры. При высоком расходе марганец - оловянной лигатуры образовавшуюся пену перемешивают с окислителем [63]. В качестве окислителя используют кальцинированную соду или известь в виде порошка. Однако, воздух и порошковый окислитель увеличивают долю окисленного олова, повышая выход съемов. Пена соединений мышьяка растекается по поверхности расплавленного олова. При длительном перемешивании пропеллерной мешалкой пена становится вязкой, расслаивается от олова и свободно отделяется от олова. Ручное отделение пены с поверхности шумовками (перфорированными ложками) представляет собой трудоемкую операцию. При более длительном перемешивании пена становится пористой и даже возгораться преврашаясь в черный порошок. С увеличением длительности перемешивания увеличивается выход сухих съемов, т.е. увеличивается окисление пленки олова на поверхности твердых кристаллов [17]. Во время центробежной фильтрации такие порошкообразные съемы заполняют щель фильтра тонким уплотненным слоем, который становится не проницаем для циркуляции расплава. Фильтрация протекает с многократными циклами с малой заполненностью полости фильтра.

Практически более удобным зернистым материалом для вмешивания в пену являлись древесные опилки обеспечивающим наполнение полости фильтра кристаллами из пены. Металл при заданной температуре перемешивался пропеллерной мешалкой с образованием воронки, в которую загружалась навеска древесных опилок. Во время перемешивания фиксировался момент начала образования сыпучих схемов, что условно считалось достаточной степенью окисления пены. После образования сыпучих съемов в металл погружались тарели центрифуги и проводилось отделение съемов. В табл. 1.21 приведены опыты по окислению пены в съемы перемешиванием олова на воздухе с древесными опилками с разным расходом марганца [17].

Из табл. 1.21 видно, что при удельном расходе марганца Mn/As > 1,1 резко снижается содержание As в металле после фильтрации, а при удельном расходе марганца $\mathrm{Mn} / \mathrm{As}>1,7$ резко возрастает выход съемов. С увеличением температуры перемешивания увеличивается выход окисленных съемов. При перемешивании чернового олова в виде суспензии твердых кристаллов $\mathrm{FeSn}_{2}$ и $\mathrm{MnAs}$ пленки олова на кристаллах окисляются с поверхности и становятся мало смачиваемые. Однако, выход олова зависит от степени окисления не только пленки на кристаллах, но и окисления основного металла [17]. В условиях фильтрации расплава 
после обработки расплава с пеной древесными опилками обеспечивают накопление полости фильтра дисперсными частицами. Щель фильтра забивается обуглившимися частицами опилок, которые являются пористым фильтром для частиц микронных размеров [18].

Таб ли ц а 1.21

Влияние расхода марганца на удаление мышьяка в виде окисленных съемов

\begin{tabular}{|c|c|c|c|c|c|c|c|c|c|}
\hline \multirow{2}{*}{$\begin{array}{c}\text { Но- } \\
\text { мер } \\
\text { опыта }\end{array}$} & \multirow{2}{*}{$\begin{array}{l}\text { Расход } \\
\text { Mn/As }\end{array}$} & \multirow{2}{*}{$\begin{array}{c}\text { Время } \\
\text { окис- } \\
\text { ления, } \\
\text { мин }\end{array}$} & \multirow{2}{*}{$\begin{array}{l}\text { Ско- } \\
\text { рость } \\
\text { окис- } \\
\text { ления, } \\
\text { кг/мин }\end{array}$} & \multirow{2}{*}{$\begin{array}{c}\text { Вы- } \\
\text { ход } \\
\text { съе- } \\
\text { мов, } \\
\%\end{array}$} & \multicolumn{2}{|c|}{$\begin{array}{c}\text { Анализ } \\
\text { съемов, \% }\end{array}$} & \multirow{2}{*}{$\begin{array}{c}\text { Содер- } \\
\text { жание, } \\
\%, \text { Аs } \\
\text { в филь- } \\
\text { трат } \\
\text { металле }\end{array}$} & \multirow{2}{*}{$\begin{array}{c}\text { Сте- } \\
\text { пень } \\
\text { очист- } \\
\text { ки, \% }\end{array}$} & \multirow[b]{2}{*}{$\mathrm{Sn} /(\mathrm{As}+\mathrm{Mn}$} \\
\hline & & & & & As & $\mathrm{Mn}$ & & & \\
\hline 1 & 0,25 & 15 & 0,08 & 3 & 0,51 & 1,1 & 0,05 & 27,8 & 61,1 \\
\hline 2 & 0,53 & 13 & 0,07 & 2,37 & 0,47 & 1,92 & 0,05 & 20,3 & 40,8 \\
\hline 3 & 1,13 & 23 & 0,04 & 2,1 & 1 & 2,3 & 0,03 & 41,0 & 29,3 \\
\hline 4 & 1,82 & 7 & 0,11 & 2 & 2,18 & 3,02 & 0,01 & 79,3 & 18,2 \\
\hline 5 & 2,55 & 7 & 0,29 & 5 & 1,33 & 2,2 & 0,01 & 86,9 & 27,3 \\
\hline
\end{tabular}

Примечание. Исходная навеска металла - 40 кг, исходное содержание As 0,055\%, Расход опилок в 0,2 кг, Температура $360^{\circ} \mathrm{C}$.

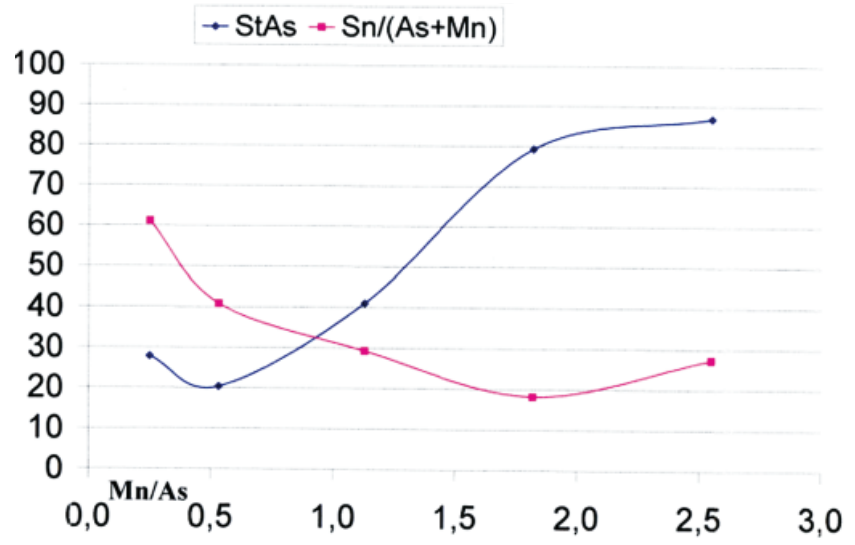

Рис. 1.37. Влияние удельного расхода марганца на показатели рафинирования олова. По абсциссе - соотношение Mn/As в загрузке; По ординате - StAs - степень очистки олова от $\mathrm{As} \% ; \mathrm{Sn} /(\mathrm{As}+\mathrm{Mn})$ - относительный выход олова в съемы 
На рис. 1.37 видно, что с увеличением удельного расхода марганца Mn/As степень очистки возрастает по уравнению:

$$
S t t_{\mathrm{As}}=31 \cdot(\mathrm{Mn} / \mathrm{As})+12,4 \text { с корреляцией } 0,92 \text {. }
$$

Удельный выход олова в съемы $\mathrm{Sn} /(\mathrm{As}+\mathrm{Mn})$ уменьшается с увеличением удельного расхода марганца $\mathrm{Mn} / \mathrm{As}$ по уравнению:

$$
\mathrm{Sn} / \mathrm{As}+\mathrm{Mn})=52,8-13,9 \cdot(\mathrm{Mn} / \mathrm{As}) \text { с корреляцией } 0,83 \text {. }
$$

В общем виде максимальная степень очистки и минимальный удельный выход олова в съемы достигается при нагреве металла до $450^{\circ} \mathrm{C}$ с последующим охлаждением и фильтрацией при $300^{\circ} \mathrm{C}$. Окисление олова на поверхности кристаллов основано на том, что поверхностные пленки с большей скоростью окисляются, чем в объеме металла. Образцы проб марганец мышьяковых съемов регулярно проверялись на способность выделения мышьяковистого водорода по ранее указанной методике. При действии воды на съемы мышьяковистый водород не выделяется, что облегчает их хранение, транспортировку и переработку.

\subsection{1. Ситовая характеристика и тодщина пленки олова на кристадлах окисленных съемов}

В табл. 1.22 приведена ситовая характеристика съемов после окисления на воздухе. Состав съемов: 7,24\% As; 0,72\% Fe; 9,9\% $\mathrm{Mn} ; 16,8 \%$ $\mathrm{MnSn}_{2} ; 17,1 \% \mathrm{MnAs} ; 5,6 \% \mathrm{SnO}_{2} ; 45 \% \mathrm{Sn}_{\text {мет }}[17]$.

Таблица 1.22

Ситовая характеристика образца съемов центробежной фильтрацией

\begin{tabular}{|c|c|c|c|c|}
\hline Фракция, мм & $\begin{array}{c}\text { Среднее, } \\
\text { мм }\end{array}$ & $\begin{array}{c}\text { Удельная поверх- } \\
\text { ность } S, \text { см}^{2} / \Gamma\end{array}$ & $\begin{array}{c}\text { Доля фракции, } \\
\%\end{array}$ & $\begin{array}{c}\text { Интегральное } \\
\text { содержание, } \%\end{array}$ \\
\hline$-0,074$ мм & 0,05 & 58,0 & 35,3 & 35,3 \\
\hline$-0,1+0,074$ мм & 0,08 & 2,7 & 2,6 & 37,9 \\
\hline$-0,14+0,1$ мм & 0,12 & 12,1 & 17,65 & 55,55 \\
\hline$-0,2+0,14$ мм & 0,16 & 3,4 & 6,7 & 62,25 \\
\hline$-0,45+0,2$ мм & 0,35 & 4,0 & 17,2 & 79,45 \\
\hline$-1+0,45$ мм & 0,75 & 1,6 & 14,3 & 93,75 \\
\hline$-2+1$ мм & 1,5 & 0,15 & 2,65 & 96,4 \\
\hline+2 мм & 2,2 & 0,13 & 3,6 & 100 \\
\hline
\end{tabular}


Образцы съемов после фильтрации при $350^{\circ} \mathrm{C}$, содержащие $6,8 \% \mathrm{As}$, $13 \% \mathrm{Mn}, 80 \% \mathrm{Sn}$, в том числе $4,4 \% \mathrm{SnO}_{2}$, имели удельную поверхность $0,2 \mathrm{~m}^{3} / \Gamma$, определенную методом адсорбции аргона. Расчеты по этим данным показывают, что с 6,8\% мышьяка связано $5 \%$ марганца. Остальной избыток марганца связан с 34,6\% олова. Свободного олова на кристаллах съемов остается по разности с анализом 45,4\% [17].

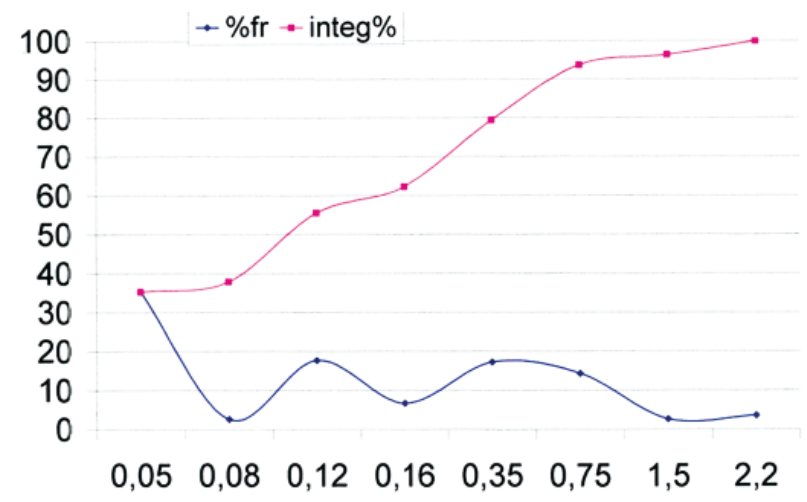

Рис. 1.38. Гистограмма образиа окисленных сбемов:

1 - доля фракции, \%; 2-интегральная доля, \%

Гистограмма на рис. 1.38 показывает, что пылевидной фракции меньше 0,1 мм составляет $50 \%$ с удельной поверхностью около $73 \%$. Поэтому производительность фильтрации съемов занижена, а удельный выход олова в съемы высокий [17]. При среднем размере кристаллов 0,38 микрона и указанной удельной поверхности кристаллов, толщина пленки олова по расчету составляет 0,33 микрона, в том числе толщина пленки окиси олова 0,03 микрона [18]. Поэтому такая суспензия мелкодисперсных кристаллов покрытая значительной толщины пленкой металлического олова и окисла олова подтверждает основание представить ее как «пена». Вмешивание древесных опилок в металлическую пену на поверхности олова ведет к термической обработке древесных опилок с выделением влаги, смолистых веществ и окиси углерода. В результате пиролиза древесины выделяются летучие вещества. Выход летучих веществ из древесины начинается при температуре $200^{\circ} \mathrm{C}$, причем скорость их выделения увеличивается с повышением температуры. Сначала происходит разложение гемицеллюлозы, а затем, при более высокой температуре, разложение целлюлозы. Полное выделение летучих веществ происходит при температуре $400^{\circ} \mathrm{C}$ [64]. Продуктами пиролиза древесины 
являются в основном смола, уголь и газы с низким молекулярным весом. Также могут выделяться значительные количества окиси и двуокиси углерода. Образующиеся при этом микропоры размером 2-50 нм соизмеримы с размерами адсорбирующихся частиц примесей [17]. В условиях фильтрации расплава после обработки расплава с пеной древесными опилками обеспечивают накопление полости фильтра дисперсными частицами. Щель фильтра забивается обуглившимися частицами опилок, которые являются пористым фильтром для частиц таких микронных размеров [65]. Мышьяково-марганцевая пена при обработке древесными опилками хорошо отделяется от расплавленного металла и задерживается в фильтрующем роторе центрифуги. Выход олова в съемы составил 3,5-8\% меньше, чем выход в пену, хотя и больше, чем по варианту откачивания металла из под пены.

\subsection{2. Промышленные испытания удаления окисленной пены AsMn}

Снижение выхода марганец-мышьяковой пены и ее отделение от металла в виде сыпучих съемов были достигнуты путем вмешивания древесных опилок перед фильтрацией (табл. 1.23).

Таблица 1.23

Результаты опытно промышленных испытаний способа удаления мышьяка марганцем

\begin{tabular}{|c|c|c|c|c|}
\hline \multicolumn{2}{|c|}{ Содержание As в металле, \% } & \multirow{2}{*}{$\begin{array}{l}\text { Степень удале- } \\
\text { ния мышьяка, \% }\end{array}$} & \multirow{2}{*}{$\begin{array}{l}\text { Расход марган- } \\
\text { ца, кг Mn/т Sn }\end{array}$} & \multirow{2}{*}{$\begin{array}{c}\text { Выход } \\
\text { съемов, \% }\end{array}$} \\
\hline исходном & после рафинирования & & & \\
\hline 0,4 & 0,01 & 97,5 & 5,0 & 5,9 \\
\hline 0,15 & 0,01 & 99,3 & 2,6 & 7,7 \\
\hline 0,2 & 0,01 & 99,5 & 4,1 & 4,5 \\
\hline 0,13 & 0,01 & 99,2 & 2,9 & 6,2 \\
\hline 0,1 & 0,01 & 99,0 & 2,6 & 5,0 \\
\hline
\end{tabular}

В промышленных условиях способ осуществлялся следующим образом. В расплав при перемешивании загружается расчетное количество марганцевой лигатуры и в образуюшуюся пену вмешивается порция древесных опилок до образования сухих съемов. Фильтр центрифуги погружается в расплав, заполняется съемами и поднимается над поверхностью металла в котле. Съемы разгружаются в кольцевой желоб скребкового транспортера, а фильтр вновь погружается в расплав. Циклы центрифугирования повторяются до тех нор, пока поверхность расплава 
не очистится от съемов. Мышьяково-марганцевая пена при обработке древесными опилками хорошо отделяется от расплавленного металла и задерживается в фильтрующем роторе центрифуги [40]. В табл. 1.24 приведены опытно промышленные плавки рафинирования олова от остаточного и мышьяка совмещенного с вмешиванием марганцевой лигатуры и древесных опилок с последующей фильтрацией [26].

Та бли ца 1.24

Результаты опытно промышленных плавок рафинирования олова от остаточного мышьяка

\begin{tabular}{|c|c|c|c|c|c|c|c|c|c|c|}
\hline \multirow{2}{*}{$\begin{array}{l}\text { Номер } \\
\text { плавки }\end{array}$} & \multicolumn{3}{|c|}{ Состав металла, \% } & \multicolumn{4}{|c|}{ Состав съемов } & \multirow{2}{*}{$\mathrm{Sn} /(\mathrm{Fe}+\mathrm{As})$} & \multicolumn{2}{|c|}{$\begin{array}{c}\text { Степень } \\
\text { очистки, \% }\end{array}$} \\
\hline & $\mathrm{Fe}$ & As & $\mathrm{Fe} / \mathrm{As}(\mathrm{pszf})$ & $\begin{array}{l}\mathrm{Fe}, \\
\%\end{array}$ & $\begin{array}{c}\text { As, } \\
\%\end{array}$ & $\begin{array}{l}\mathrm{Sn}, \\
\%\end{array}$ & $\mathrm{Fe} / \mathrm{Asc}$ & & $\mathrm{Fe}$ & As \\
\hline 23 & 0,16 & 0,2 & 2,1 & 1,95 & 3,14 & 81,5 & 0,8 & 16 & 70,4 & 90,6 \\
\hline 37 & 0,76 & 0,44 & 0,9 & 12,4 & 5,9 & 63,4 & 2,8 & 3,5 & 95,0 & 78,5 \\
\hline 40 & 0,11 & 0,45 & 0,8 & 1,97 & 7,1 & 61,9 & 0,4 & 6,8 & 88,5 & 76,6 \\
\hline 54 & 0,24 & 0,26 & 1,3 & 4,28 & 4,37 & 76,3 & 1,3 & 8,8 & 69,9 & 66,4 \\
\hline 20 & 0,56 & 0,14 & 0,8 & 10,9 & 2,3 & 73,1 & 6,4 & 5,5 & 94,9 & 79,8 \\
\hline 18 & 0,18 & 0,13 & 0,6 & 6,17 & 2,4 & 69,6 & 3,4 & 8,1 & 94,5 & 49,1 \\
\hline 119 & 0,24 & 0,21 & 1,2 & 7,44 & 5,9 & 65,8 & 1,7 & 4,9 & 92,1 & 86,1 \\
\hline
\end{tabular}

Для выделения мышьяка в отдельный возгон-продукт «окись мышька» полученные мышьяковистые съемы рафинирования олова съемы смешивают с материалом-окислителем, содержащим окись марганца оборотный в качестве которого используют огарок в количестве 5-15\% от веса съемов, и окислительный обжиг ведут сначала при $300-450^{\circ} \mathrm{C}$, а затем повышают температуру до $600-800^{\circ} \mathrm{C}$ для возгона окиси мышьяка [66]. В переработке оловосодержащих материалов электроплавкой, с целью повышения степени извлечения олова, в качестве флюса, содержащего окись марганца, предложено [67] использовать съемы рафинирования олова марганцем. Это позволяет выводить мышьяк из съемов в возгон окиси мышьяка.

\section{8. Удаление меди центробежной фильтрацией совместно с остаточным марганцем}

После удаления остаточного мышьяка олово рафинируют от меди Н.Н. Мурач [1] описал практику рафинирования олова от меди. В промышленных условиях вмешивание серы в расплавленный металл производится под вращающуюся мешалку. При вращении мешалки в металле 
образуется воронка, в которую втягивается загружаемая сера вглубь ванны и проходит реакция растворения серы с минимальным сгоранием на воздухе. Образующиеся сульфиды всплывают на поверхность, откуда их снимают вручную шумовкой. Другие примеси такие как свинец, сурьма, висмут в любых содержаниях не мешают удалению меди серой. Опыты проводились на лабораторной центрифуге (рис. 1.1) по ранее описанной методике. После вмешивания серы в течение 5 мин начиналась фильтрация припоя от образовавшегося сульфида меди. Фильтр диаметром 130 мм погружался в расплав и приводился во вращение для сбора твердых съемов. После наполнения фильтра его приподнимали над расплавом и увеличивали скорость вращения до 1200 об/мин на 30 с. Цикл повторялся до получения удовлетворительного анализа припоя. В табл. 1.25 приведены характерные опыты по фильтрации расплава от сульфидных съемов [68].

Таблица 1.25

Расход серы для удаления меди из оловяно свинцовых сплавов

\begin{tabular}{|c|c|c|c|c|c|c|c|}
\hline \multicolumn{2}{|c|}{ Загружены отходы } & \multirow{2}{*}{$\begin{array}{l}\text { Расход, } \\
\text { г } \mathrm{S} / \text { г } \mathrm{Cu}\end{array}$} & \multirow{2}{*}{$\begin{array}{l}\text { Получен ме- } \\
\text { талл Сu, \% }\end{array}$} & \multicolumn{2}{|c|}{ Анализ съемов, \% } & \multirow{2}{*}{$\begin{array}{l}\text { Выход } \\
\mathrm{Sn} / \mathrm{Cu}\end{array}$} & \multirow{2}{*}{$\begin{array}{c}\text { Степень } \\
\text { очистки, \% }\end{array}$} \\
\hline вес, кг & $\mathrm{Cu}, \%$ & & & $\mathrm{Cu}$ & $\mathrm{Sn}$ & & \\
\hline 115,8 & 3,2 & 0,11 & 2,16 & 13,4 & 79,9 & 5,9 & 38,8 \\
\hline 105 & 2,16 & 0,18 & 0,68 & 15,2 & 88,8 & 5,8 & 71,8 \\
\hline 94 & 0,68 & 0,62 & 0,012 & 5,4 & 82,1 & 15,1 & 98,5 \\
\hline 115 & 2,2 & 0,16 & 1,5 & 9,3 & 79,2 & 8,5 & 37,9 \\
\hline 104 & 1,5 & 0,25 & 0,24 & 8,8 & 92,1 & 10,4 & 86,8 \\
\hline 115 & 0,5 & 0,7 & 0,006 & 4,8 & 85,6 & 17,9 & 98,9 \\
\hline
\end{tabular}

Обработка подобных опытов приводит к следующим выводам. При расходе серы относительно содержания меди менее $(\mathrm{S} / \mathrm{Cu})<1$ несмотря на высокую степень очистки не достигается необходимое качество очистки $<0,01 \% \mathrm{Cu}$. Поэтому для получения высокого качества очистки поддерживается уровень расхода серы $(\mathrm{S} / \mathrm{Cu})>0,7$.

С увеличением расхода $S$ удельный выход олова на единицу удаленной меди $(\mathrm{Sn} / \mathrm{Cu})$ увеличивается по уравнению:

$$
(\mathrm{Sn} / \mathrm{Cu})=18,7 \cdot S+4,3 \text { с корреляцией } 0,94 \text {. }
$$

Длительность обработки до образования сухих съемов составляла 5 мин. При одном и том же расходе серы за один прием возможно удаление меди до следующих содержаний:

$$
\text { с } 2,4-3 \% \text { до } 0,7-0,8 \% \text {; }
$$




$$
\begin{gathered}
\text { с } 0,7-1,25 \text { до } 0,17-0,4 \% ; \\
\text { с } 0,2-0,14 \text { до } 0,005-0,015 \% \text {. }
\end{gathered}
$$

При удельном расходе серы $(\mathrm{S} / \mathrm{Cu})=1 \pm 0,2$ средний выход съемов $8,8 \pm 1,2 \%$; а средняя степень очистки составляет $84,7 \pm 6,3 \%$. Опыты показали, что с увеличением температуры рафинирования припоя с $280-400^{\circ} \mathrm{C}$ выход съемов увеличивается, а степень очистки припоя практически остается без изменений.

Для диапазона исходного содержания меди $0,1-1 \%$ выход съемов изменяется по уравнению:

$$
V i x=0,05 \cdot T-3,8 \text { с корреляцией } 0,71 .
$$

Степень удаления меди с температурой изменяется по уравнению:

$$
S t u d=197-0,37 \cdot T \text { с корреляцией } 0,8 .
$$

Оптимальная температура удаления съемов можно признать $280^{\circ} \mathrm{C}$.

В целом оправдана принятая практикой оптимальная температуpa $280-350^{\circ} \mathrm{C}$.

Длительность вмешивания серы мало влияет на степень очистки и несколько больше влияет на выход съемов. При длительности более 5 мин выход съемов возрастает в среднем по уравнению:

$$
V i x=5,7(\min )-5,5 \text { с корреляцией } 0,85 \text {. }
$$

В целом выделяются стадии процесса: На удаление основной меди $>0,12 \%$ при температуре $280-350{ }^{\circ} \mathrm{C}$ расход серы выдерживают $(\mathrm{S} / \mathrm{Cu})<0,4$ с отделением выхода съемов $8 \%$. На удаление остаточной меди $<0,12 \%$ при температуре с 260 до $320^{\circ} \mathrm{C}$ расход серы выдерживают 0,5-1,2 (S/Cu) со средним выходом съемов $18 \%$. В общем виде удаление меди можно разбить на три стадии (табл. 1.26): при содержании меди более $1 \%$ сера с расходом $0,1 \% \mathrm{~S} / \mathrm{Cu}$ вмешивается при $350^{\circ} \mathrm{C}$ до коричневых съемов. При $\mathrm{Cu}=0,2-1 \%$ сера с расходом $0,3 \% \mathrm{~S} / \mathrm{Cu}$ вмешивается при $350-280^{\circ} \mathrm{C}$ до серых съемов. При Сu менее $0,2 \%$ сера с расходом $1 \% \mathrm{~S} / \mathrm{Cu}$ вмешивается при $350-280^{\circ} \mathrm{C}$ до черных съемов.

Сопутствуюшие растворимые легкоплавкие металлы свинец, висмут, сурьма не мешают удалению меди из олова. В олово с содержанием $1,9 \% \mathrm{Cu}$ и $0,25 \%$ As при температуре $350^{\circ} \mathrm{C}$ гр вмешивали $7 \%$ марганцевую лигатура с расходом $\mathrm{Mn} / \mathrm{As}=1,04$. Сняли мышьяково марганцеву пену с выходом 7,3\% с относительным выходом олова $\mathrm{Sn} / \mathrm{As}=28,9$. В табл. 1.27 приведены результаты их удаления меди. 
Таблица 1.26

Опыты стадийного удаления меди

\begin{tabular}{|c|c|c|c|c|c|c|c|}
\hline & \multirow{2}{*}{$\begin{array}{c}\text { Расход } S, \\
\Gamma / \Gamma\end{array}$} & \multirow{2}{*}{$T$} & \multicolumn{2}{|c|}{ Сод меди } & \multirow{2}{*}{$\begin{array}{c}\text { Выход } \\
\text { съемов }\end{array}$} & \multirow{2}{*}{$\begin{array}{l}\text { Степень } \\
\text { очистки }\end{array}$} & \multirow{2}{*}{ Вид съемов } \\
\hline & & & до & после & & & \\
\hline 1 & 0,1 & 350 & 2,3 & 0,98 & 4,6 & 59,2 & коричневый \\
\hline 2 & 0,1 & 350 & 2 & 0,95 & 5,7 & 58,0 & коричневый \\
\hline 3 & 0,3 & 350 & 0,98 & 0,21 & 6,2 & 79,9 & серо-черный \\
\hline 4 & 0,3 & 350 & 0,95 & 0,32 & 5,3 & 84,5 & серо-черный \\
\hline 5 & 1 & 350 & 0,21 & 0,007 & 6,6 & 97,3 & черный \\
\hline 6 & 1 & 280 & 0,32 & 0,014 & 7,6 & 95,7 & черный \\
\hline
\end{tabular}

Таблица 1.27

Результаты опытов удаления меди

\begin{tabular}{|c|c|c|c|c|c|c|c|c|}
\hline \multirow{2}{*}{ Опыт, операция } & \multirow{2}{*}{$T$} & \multirow{2}{*}{$\mathrm{S} / \mathrm{Cu}$} & \multirow{2}{*}{$\begin{array}{c}\text { Загруз- } \\
\text { ка, кг }\end{array}$} & \multirow{2}{*}{$\begin{array}{l}\text { Сня- } \\
\text { то, Кг }\end{array}$} & \multirow{2}{*}{$\begin{array}{c}\text { Вы- } \\
\text { ход, \% }\end{array}$} & \multicolumn{2}{|c|}{ Содержание, \% } & \multirow{2}{*}{$\mathrm{Sn} / \mathrm{Cu}$} \\
\hline & & & & & & $\mathrm{Cu}$ & $\mathrm{Fe}$ & \\
\hline Исходный металл & & & 116 & & & 3,20 & 0,013 & \\
\hline Фильтр съемы Сu & & 0,22 & & 24 & 20,7 & 10,8 & 0,015 & 7,6 \\
\hline Очищенный металл & 310 & & 91,9 & & & 0,7 & 0,006 & \\
\hline Вмешивание серы & & 0,64 & 0,4 & & & & & \\
\hline Фильтр съемы Cu & & & & 11,6 & 10,0 & 6,2 & 0,020 & 13,2 \\
\hline Очищенный металл & & & 80,3 & & & 0,012 & 0,004 & \\
\hline
\end{tabular}

Для удаления остаточных содержания марганца удаляется совместно с удалением меди как показано в табл. 1.28.

Таблица 1.28

Фильтрация съемов остаточного марганца

\begin{tabular}{|c|c|c|c|c|c|c|c|}
\hline \multirow{2}{*}{ Опыт, операция } & \multirow{2}{*}{$T$} & \multirow{2}{*}{$\begin{array}{c}\text { Загрузка, } \\
\text { кг }\end{array}$} & \multirow{2}{*}{$\begin{array}{c}\text { Снято, } \\
\text { Кг }\end{array}$} & \multirow{2}{*}{$\begin{array}{c}\text { Выход, } \\
\%\end{array}$} & \multicolumn{3}{|c|}{ Содержание, \% } \\
\hline & & & & & $\mathrm{Cu}$ & As & $\mathrm{Mn}$ \\
\hline Исходный металл Р-146 & & 42,4 & & & 1,9 & 0,25 & \\
\hline Загрузка лигатуры, Mn & 350 & 1,6 & & & & & 7 \\
\hline Металл с Mn & & 43,9 & & & 1,8 & 0,24 & 0,25 \\
\hline Снятие пены & 280 & & 3,2 & 7,3 & 1,8 & 3,18 & 3,27 \\
\hline Раф. металл & & 40,7 & & & 1,8 & 0,01 & 0,26 \\
\hline Вмеш. серы 3 прием & 260 & 0,51 & & & & & \\
\hline Фильтр съемов Сu, Mn & & & 7,46 & 18,3 & 10,0 & 0,21 & 1,4 \\
\hline Отрафинировано олово & & 33,26 & & & 0,005 & 0,01 & 0,001 \\
\hline
\end{tabular}


Удаление остаточного марганца и меди сопровождается значительно высоким выходом олова в съемы, и поэтому предпринимались попытки усовершенствовать этот процесс.

Известные приемы удаления меди серой имеют недостаток в ручной разгрузке дымяших и пылящих съемов. Обезмеживание обладает также тем недостатком, что вместе с сульфидом меди в съемы в значительном объеме выводится олово в виде сульфидов, окислов.

Без существенного изменения химизма процесса проводили отладку совместного удаления съемов меди и марганца центробежной фильтрацией расплава. При испытании технологии регенерации припоев от меди проводилась отладка работы модели центрифуги ЦП-100с для экспорта (рис. 1.39).

Для обеспечения оптимального набора съемов фильтр заглублялся на 90-100 мм в расплав при температуре $300^{\circ} \mathrm{C}$ [68]. При задаваемой с пульта скорости забора 300 об/мин и длительности вращения фильтра 1-2 мин достигалась необходимое наполнение фильтра. Осушка съемов от жидкого припоя (отжим) осуществлялся в течение 30 с при скорости вращения 1200 об/мин. Сера вмешивается в металл до образования всплывающих сыпучих съемов. Сульфид олова из сухих съемов

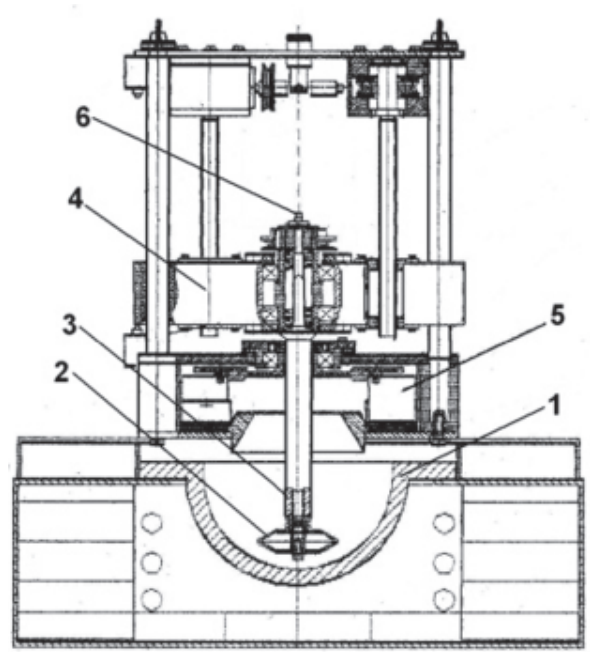

Рис. 1.39. Центрифуга фильтрации отходов припоев от меди.

Основные узлы: 1 - котел; 2 - фильтр;

3-ротор; 4-механизм подъема фильтра; 5- транспортер;

6 - механизм открытия тарелей не смачивается жидким оловом и поэтому реакция обмена с растворенной медью медленно протекает. Поэтому увеличивается выход олова в съемы, Для снижения образования сульфида олова и окисления вмешивание серы осуществляли при температуре $240-260^{\circ} \mathrm{C}$. Затем поверхность расплава покрывают полиметилсилоксановым маслом (ПМФС) с покрытием поверхности расплава и перемешивают с нагревом до температуры $300-320^{\circ} \mathrm{C}$ для образования съемов. Предложенный режим позволяет обеспечивать условия более полного связывания серы с медью. В табл. 1.29 представлены сравнительные результаты опытов обезмеживания припоев фильтрацией [68]. 
Табли ц а 1.29

Результаты испытаний фильтрации отходов оловянных припоев

\begin{tabular}{|c|c|c|c|c|c|c|c|c|}
\hline \multirow{2}{*}{$\begin{array}{c}\text { Тип от- } \\
\text { ходов }\end{array}$} & \multicolumn{2}{|c|}{ Загружены отходы } & \multirow{2}{*}{$\begin{array}{l}\text { Расход } \\
(\mathrm{S} / \mathrm{Cu})\end{array}$} & \multicolumn{3}{|c|}{ Выделенные съемы } & \multirow{2}{*}{$\begin{array}{l}\text { Выход } \\
\mathrm{Sn} / \mathrm{Cu}\end{array}$} & \multirow{2}{*}{$\begin{array}{l}\text { Расход } \\
\text { масла }\end{array}$} \\
\hline & вес, кГ & $\mathrm{Cu}, \%$ & & вес, кГ & $\mathrm{Cu}, \%$ & $\mathrm{Sn}, \%$ & & \\
\hline 1 & 39,7 & 2,1 & 0,48 & 8,02 & 10,37 & 83,7 & 10,2 & 0 \\
\hline 2 & 44,7 & 2,3 & 0,58 & 10 & 10,26 & 77,1 & 9,1 & 0,19 \\
\hline 1 & 52,15 & 1,5 & 0,60 & 4,18 & 18,6 & 81 & 4,4 & 0 \\
\hline 2 & 54,03 & 1,9 & 0,53 & 5,57 & 18,39 & 80,5 & 4,4 & 0,14 \\
\hline
\end{tabular}

Примечание. Расход масла ПМФС г на см² поверхности расплава.

Таблица 1.30 показывает, что применение масла снижает выход олова в съемы.

Табли ца 1.30

Сравнение показателей очистки припоев от меди

\begin{tabular}{|l|c|c|}
\hline \multicolumn{1}{|c|}{ Средние показатели } & На воздухе & С маслом \\
\hline Средний выход съемов, \% & 21,0 & 9,2 \\
\hline Расход серы (S/Cu) & 0,54 & 0,55 \\
\hline Степень очистки от $\mathrm{Cu}, \%$ & 82,5 & 98,7 \\
\hline Выход олова в съемы, \% & 18,5 & 8,0 \\
\hline Удельный выход $\mathrm{Sn} / \mathrm{Cu}$ в съемы & 7,3 & 6,7 \\
\hline Степень изменения легирующего металла, \% & 10,2 & 5,0 \\
\hline
\end{tabular}

Несмотря на значительное снижение выхода олова в съемы этот прием не нашел практического применения из-за дороговизны реагента. Прием удаления меди с масляным покрытие оправдан для очистки серебросодержащих отходов припоев. Подобная необходимость возникает при обезмеживании припоев полученных после регенерации серебросодержащих припоев из отходов нагретых печатных плат на контейнерной центрифуге [60].

В работе [69] приведен баланс распределения $\mathrm{Sn}, \mathrm{Pb}, \mathrm{Sb}, \mathrm{Ag}$ при регенерации припоев из отходов печатных плат. Сера растворяется в олове при $300^{\circ} \mathrm{C}$ гр до $0,42 \%$ вес и с повышением содержания образуется соединением $\mathrm{SnS}$. Реакции с $\mathrm{SnS}$ и растворенной примесью $\mathrm{Cu}$ и $\mathrm{Fe}$ не проходят.

$$
2 \mathrm{Cu}+\mathrm{SnS}=\mathrm{Cu}_{2} \mathrm{~S}+\mathrm{Sn} \cdot \Delta Z=+14,9 \text { кДж/мол. }
$$


Реакция удаления меди проходит за счет реакции растворенной серы и растворенной примеси по реакции:

$$
2 \mathrm{Cu}+\mathrm{S}=\mathrm{Cu}_{2} \mathrm{~S}+\Delta Z=-92 \text { кДж/мол. }
$$

Чтобы снизить выход $\mathrm{SnS}$ в съемы предпочтительно вмешивать серу из расчета на содержание в металле не более $0,42 \%$ при температуре минимального возгорания на воздухе, т.е. при температурах $250-300^{\circ} \mathrm{C}$. Твердые частицы $\mathrm{Cu}_{2} \mathrm{~S}$ с меньшей плотностью всплывают на поверхность и их снимают шумовкой.

Одновременно с этим удаляется избыточный марганец по реакциям:

$$
\mathrm{Mn}+\mathrm{S}=\mathrm{MnS} \Delta \mathrm{Z}=-224 \text { кДж/мол. }
$$

$\mathrm{B}$ отличие от меди марганец может удаляться соединением $\mathrm{SnS}$ по реакции:

$$
\mathrm{Mn}+\mathrm{SnS}=\mathrm{MnS}+\mathrm{Sn} \cdot \Delta Z_{280}=-117,3 \text { кДж/мол. }
$$

Причем в первую очередь удаяется марганец и затем медь. Остаточный марганец может удаляться окислением на воздухе без серы. Для удаления остаточного марганца (до содержания $0,004 \%$ ) из олова в расплавленный металл при температуре $270-320^{\circ} \mathrm{C}$ вмешиваются (порциями по 5-10 кг) древесные опилки. Расплав перемешивается до образования сыпучих съемов, которые удаляются вручную шумовкой и направляются на плавку в электропечи рафинировочного отделения. Полнота удаления марганца контролируется визуально, по внешнему виду пробы (при наличии марганца. на поверхности олова в пробной ложке имеется тусклая пленка и расплав при сливе не «разбегается» на капли). При необходимости операция вмешивания опилок и удаления образующихся съемов повторяется.

Общая продолжительность операции удаления остаточного марганца составляет 1-3 часа [34]. Операция удаления остаточного марганца с медью проводится промышленным центробежным аппаратом [70], который снабжен отбойником брызг расплава, расположенным в нижней части рамы по оси фильтра, желобом кольцеобразного сборника осадка, расположенным в верхней части отбойника брызг расплава, скребковым транспортером, расположенным в желобе по его оси, с приводом и отражателем, расположенным над отбойником брызг по оси фильтра и выполненным в виде усеченного конуса.

Удаление меди сопровождается высокой загазованностью от горения серы и запыленности дисперсных сульфидов. Поэтому авторами [71] для снижения запыленности предлагалось снабдить центрифугу (рис. 1.41) разгрузочной камерой, соединенной тангенциальным каналом с источником разрежения, установленной с охватом отражателя, и демпферной камерой, установленной на тангенциальном канале, а отражатель выполняют в виде набора конусных обечаек, размещенных одна в другой с зазором и с частичным перекрытием на концевых участках. 


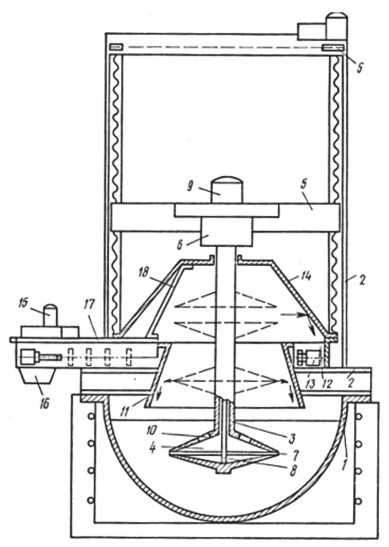

a

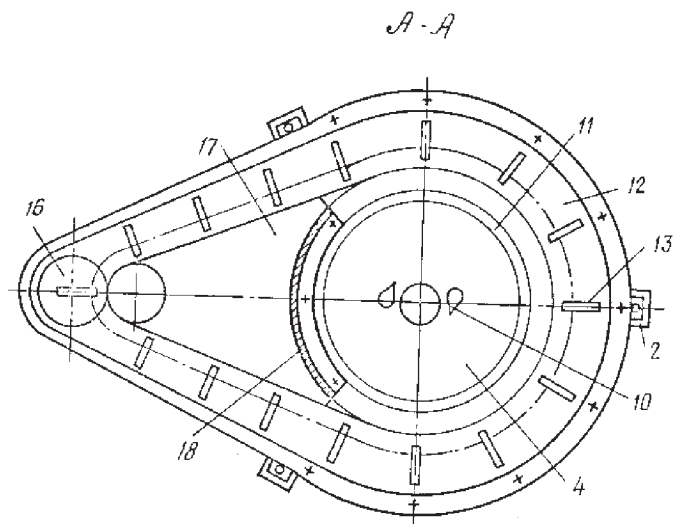

6

Рис. 1.40. Промышленный вариант иентрифуги.

Основные узлы: 11 - отбойник брызг расплава; 12 - кольцеобразный желоб осадка; 13 - скребковый транспортер; 18 -отражатель

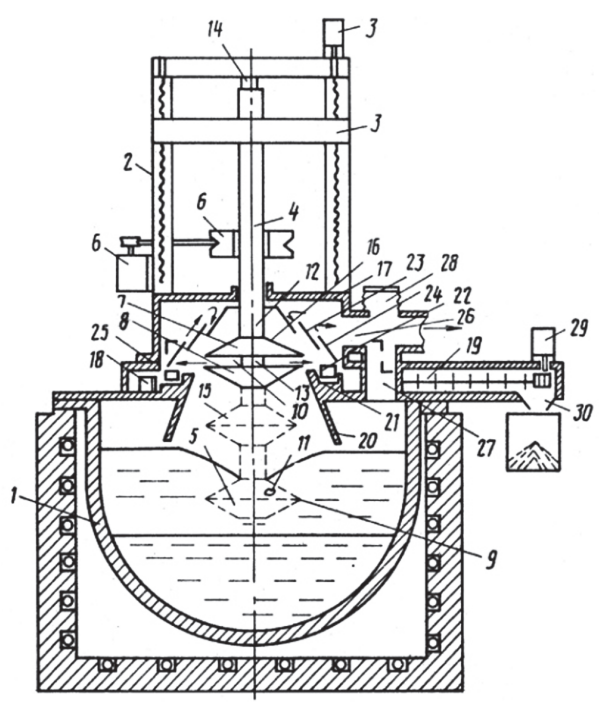

a
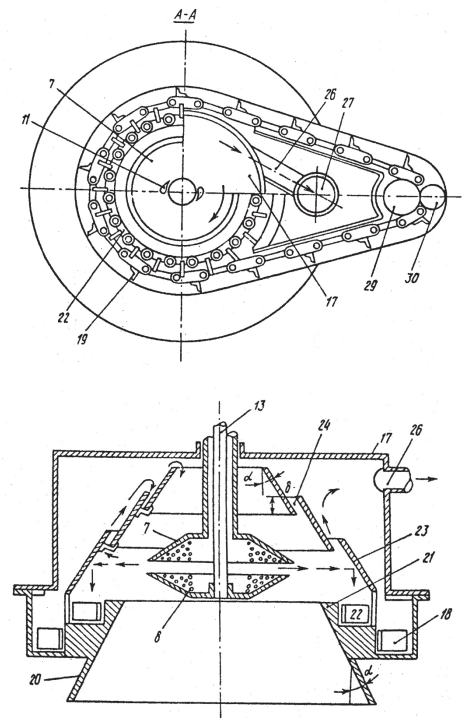

6

Рис. 1.41. Центрифуга с компенсаций давления.

Основные узлы: 1 - котел; 5- фильтриз тарелей 7, 8; 19 - транспортер осадка;

23 - обичайки с зазором 24; 26 - канал отсоса пыли 
Соосно с фильтром 5 в положении 16 установлен конусный отражатель, состоящий из набора конусных обечаек 23 , входящих друг в друга с зазором 24, а с корпусом образуют наружный зазор 25. Конусные обечайки 23 (рис. 1.41, б) с конусностью стенок $\alpha=30-50^{\circ}$ вставлены большим нижним основанием верхней обечайки с напуском $h$ во внутрь малого основания конуса нижней обечайки, в 1,5-2,0 раза большем величины зазора 6 между стенками. При выбрасывании сыпучего осадка твердых кристаллов из полости 10 вращающегося фильтра 5 (с раскрытыми тарелями 7,8 ) создается давление на воздух в полости камеры. Зазоры 24 между верхними обечайками 23 (рис. 1.41, б) обеспечивают выравнивание давлений воздуха, так как около ротора создается разрежение, а на периферии нижней обечайки создается давление. Созданный поток воздуха выдавливается через зазор 24 между отражателями 23 в верхнюю полость камеры 17. Отражатель, выполненный в виде набора конусных обечаек 23 с зазором, создает раздельный выход воздуха пришедшего в движение под давлением вылетающего из тарелей осадка. Вращающийся поток воздуха из камеры 17 по тангенциальному каналу 26 (рис. 1.41, а) отсасывается через вентиляционную трубу. Тангенциальный отсос воздуха из разгрузочной камеры 17 через тангенциальный канал 26 обеспечивает поддержание вращения запыленного воздуха в разгрузочной камере 17, сохраняя его направление на выбросе без завихреней, отделение твердых частиц, которые затем сваливаются через зазор 25 в канал транспортера 22. Демпферная камера на тангенциальном канале 26 компенсирует резкие колебания давления воздуха на выбросе осадка.

По другому варианту [72] предлагалось для снижения пыления, устройство (рис. 1.42) снабдить патрубками вакуумпровода, расположенными в камере разгрузки осадка тангенциально, причем впускные отверстия патрубков направлены в сторону, противоположную направлению вращения фильтра.

Соосно фильтру 5 в верхнем положении установлена кольцевая камера 14. В кольцевую камеру 14 (рис. 1.42, б) тангенциально с двух сторон плотно вставлены патрубки вакуум-провода 15 с задвижками 16. После осушки осадка фильтр приподнимается в верхнее положение, где механизмом 12 сжатия тарели раскрываются, и осадок под действием центробежных сил выбрасывается в кольцевую камеру 14, создавая пылевоздушный поток. В этот момент открывается задвижка 16, и твердый сыпучий (пылящий) материал отсасывается по вакуум-проводу 15.

Однако, при фильтрации зернистых съемов в них нет необходимости, а такие узлы отягощают центрифугу. Поэтому компенсирующую камеру 14 выделили в отдельную отсасывающую кольцевую камеру постоянно устанавливаемую на котел, на которую устанавливается центрифуга ЦП-500. 


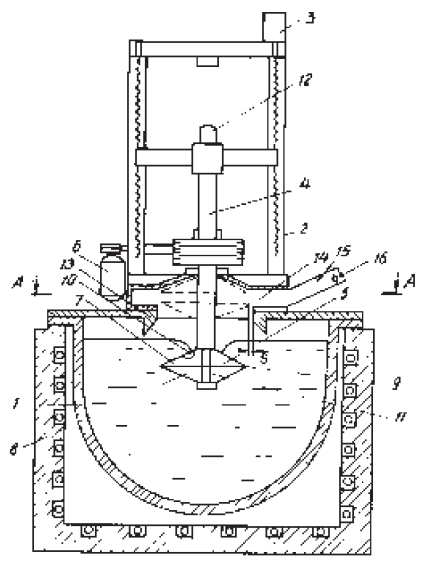

a

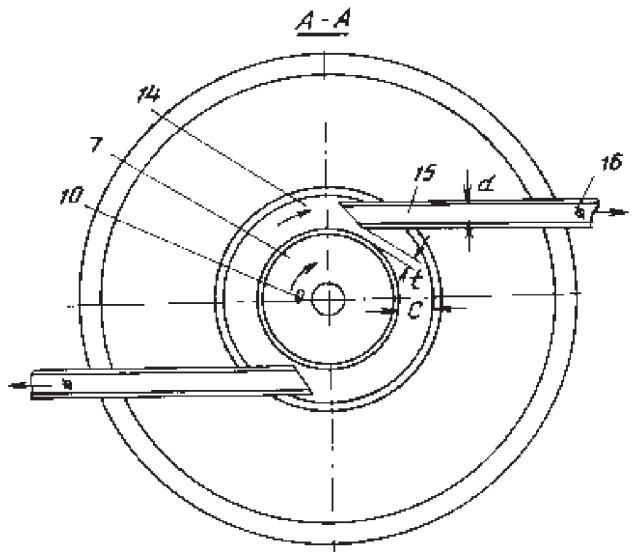

6

Рис. 1.42. Центрифуга с газоотсосом.

Основные узлы: 5 - фильтр; 14 - кольцевая камера; 15 - вакуумпровод

С целью снижения затрат на разделение и хранение съемов на практике операции удаления меди и серы совмещают. Исключением является рафиниование партий олова с высоким более $2 \%$ меди. Для концентрирования меди в медистый промпродукт олово с содержанием более $2 \%$ меди сначала удаляют остаточный марганец окислением с опилками а затем рафинируют от меди вмешиванием серы с отдельной переработкой съемов.

\section{9. Промышленное освоение центробежного рафинирования олова}

\subsection{1. Принятый вариант удаления остаточного мышьяка}

Исходя из приведенных результатов принят стадийный вариант рафинирования олова от мышьяка: первоначальная фильтрация от основного содержания железа, удаление остаточного содержания Fe, связанного с мышьяком и удаление остаточного As вмешиванием марганцево оловянной лигатуры с частичным окислением MnAs обработкой древесными опилками с центробежной фильтрацией.

\subsection{2. Приготовление марганцевой дигатуры}

После удаления основной части мышьяка и железа центрифугированием оставшийся мышьяк удаляются марганцем. С целью растворения тугоплавкого марганца в черновом олове при низкой температуре 
предварительно готовится оловянно-марганцевая лигатура. Для приготовления лигатуры используется черновое (техническое) олово, содержащее не более $0,3 \%$ мышьяка и 0,05\% железа. Однако, марганец как более легкий металл чем олово плавает на поверхности, окисляется с поверхности и поэтому очень медленно растворяется. Для вмешивания в олово тугоплавкого марганца с получением лигатуры разработан аппарат [73] (рис. 1.49), включающий цилиндрическую камеру с перфорированным перекрытием и снабженную патрубком в верхней части камеры направленной вниз по спирали вдоль корпуса. Для циркуляции расплава через камеру насос соединен выходным патрубком с нижней частью камеры. Циркуляция олова через слой кускового марганца позволяет при температуре $650^{\circ} \mathrm{C}$ получать марганец оловянную лигатуру с содержанием 5-6\% Mn.

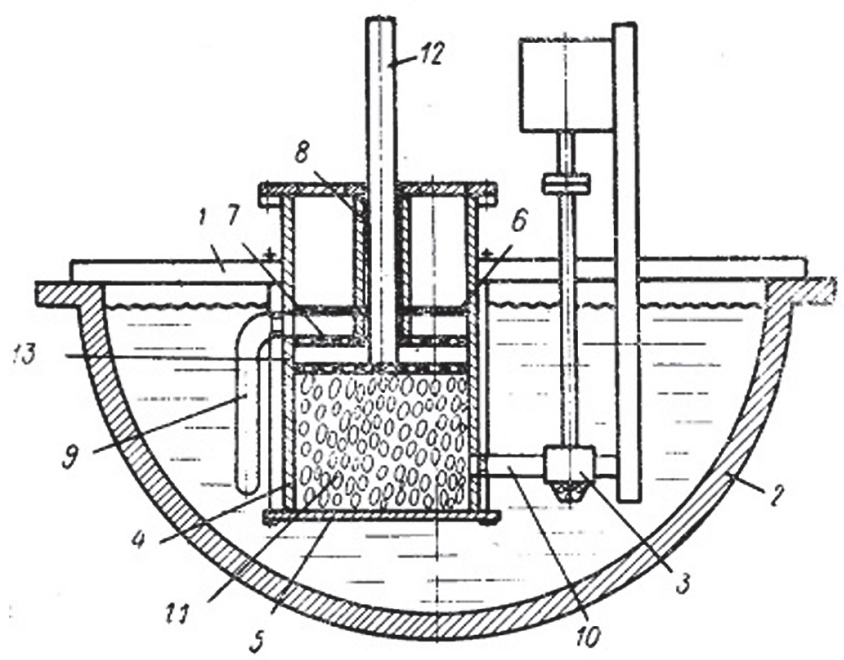

Рис. 1.43. Аппарат растворения твердых металлов в олове.

Основные узлы: 3 - насос циркуляции; 4 - камера для кусков реагента 11; 9 - патрубок слива лигатуры

В дальнейшем растворение марганца в олове для предохранения от окисления поверхности кусков марганца стали выполнять под слоем расплавленного карналитового флюса. Толщина защитного слоя флюса составляет примерно 1-2 см. Для приготовления марганцевой лигатуры, олово разогревают до температуры $350-400^{\circ} \mathrm{C}$ и в котёл загружается обезвоженный карналитовый флюс в количестве 100-200 кг. Температура 
в котле поднимается до $550-600^{\circ} \mathrm{C}$. В расплав загружается расчетное количество 1200-2500 кг марганца марки МР-1 достаточном для получения содержания марганца в лигатуре 3-7\%. Расплав перемешивается до полного растворенрия кусков марганца.

\subsection{3. Промышленное освоение центробежного рафинирования олова}

Промышленные плавки по рафинированию чернового олова от железа и мышьяка проводились на аппаратах ПАВФС-650 и ЦП-450.

В рафинировочный котел загружаются блоки чернового олова или заливается расплавленный металл из ковша. Черновое олово разогревается в котле до температуры $350-460^{\circ} \mathrm{C}$ и перемешивается в течение 15-30 мин. Затем обогрев отключается и включается обдув для охлаждения металла до $320-350^{\circ} \mathrm{C}$. При температуре $280-300^{\circ} \mathrm{C}$ под мешалку добавляют 10-20 кг древесных опилок и проводят фильтрацию до прекращения снятия съёмов [34]. После прекращения разгрузки съемов из транспортера центрифуги, процесс считается законченным центрифуга снимается с котла. После центрифугирования содержание железа в олове не должно превышать $0,05 \%$.

После предварительной фильтрации основной массы от железа с мышьяком в виде FeAs остаточный мышьяк и железо удалялся с марганцем фильтрацией с древесными опилками. В промышленных условиях способ осуществлялся следующим образом. В расплав олова при температуре $450^{\circ} \mathrm{C}$ при работающей мешалке загружалось расчетное количество марганцевой лигатуры. После образования пены в расплав вмешивалась порция 20-30 кг древесных опилок и температура снижалась до $300^{\circ} \mathrm{C}$. Фильтр центрифуги погружается в расплав, заполняется съемами, поднимается над поверхностью металла и съемы разгружались на транспортер. Циклы центрифугирования повторяются до тех нор, пока поверхность расплава не очистится от съемов. В табл. 1.31 приведены результаты промышленных плавок фильтрации олова от мышьяка с марганцем погружаемым центробежным фильтром с получением кондиционного содержания $0,001 \% \mathrm{Fe}$ и As [18].

Средний статистический состав отфильтрованных съемов $3,1 \% \mathrm{Fe}$; $15,6 \% \mathrm{As} ; 18,4 \% \mathrm{Mn} ; 62,9 \% \mathrm{Sn}$; удельный выход олова в съемы на единицу удаленных примесей $\mathrm{Sn} /(\mathrm{Fe}+\mathrm{As})=3,5$ [17].

Содержание As в отрафинированном олове с достаточно высокой достоверностью зависит от соотношения железа к мышьяку по уравнению:

$$
(\mathrm{As})_{\text {отр м }}=0,3-0,066 \cdot(\mathrm{Fe} / \mathrm{As}) \text { с корреляцией } 0,87 .
$$


Та блица 1.31

Результаты промышленных плавок фильтрации олова от мышьяка

\begin{tabular}{|c|c|c|c|c|c|c|c|c|}
\hline \multirow{2}{*}{ Плавка } & \multicolumn{2}{|c|}{ Исходный Sn } & \multicolumn{3}{|c|}{ Мышьяковистые съемы } & \multirow{2}{*}{$\mathrm{Mn}, \%$} & \multirow{2}{*}{$\begin{array}{c}\text { Выход } \\
\text { съемов, \% }\end{array}$} & \multirow{2}{*}{$\mathrm{Sn} /(\mathrm{Fe}+\mathrm{As})$} \\
\hline & $\mathrm{Fe}, \%$ & As, $\%$ & $\mathrm{Sn}, \%$ & $\mathrm{Fe}, \%$ & As, $\%$ & & & \\
\hline 1.9 . & 0,33 & 1,64 & 66,1 & 4,7 & 20,6 & 8,6 & 6,9 & 2,6 \\
\hline 1.11. & 0,26 & 1,06 & 70,3 & 4,1 & 12,7 & 12,9 & 6,1 & 4,2 \\
\hline 1.12 . & 0,17 & 0,96 & 71,0 & 3,3 & 13,8 & 11,9 & 4,8 & 4,1 \\
\hline 1.28 . & 0,2 & 1,3 & 68,6 & 2,4 & 14,3 & 14,7 & 7,9 & 4,1 \\
\hline 1.2 . & 0,25 & 1,13 & 64,7 & 3,4 & 12,3 & 19,6 & 7,0 & 4,1 \\
\hline 1.3. & 0,27 & 1,58 & 69,3 & 3,5 & 17,8 & 9,4 & 7,5 & 3,3 \\
\hline 1.40 . & 0,14 & 2,73 & 65,0 & 0,7 & 12,9 & 21,4 & 19,5 & 4,8 \\
\hline 1.43. & 0,05 & 4,1 & 65,5 & 0,2 & 18,5 & 15,8 & 21,0 & 3,5 \\
\hline 2.5 & 0,74 & 3,65 & 57,4 & 4,1 & 19,4 & 19,1 & 17,8 & 2,4 \\
\hline 1.27 & 0,45 & 1,07 & 67,5 & 5,8 & 10,9 & 15,8 & 7,6 & 4,0 \\
\hline 1.1. & 0,18 & 2,55 & 65,9 & 1,4 & 18,9 & 13,8 & 12,2 & 3,2 \\
\hline
\end{tabular}

Выход олова в съемы составил 3,5-8\%, меньше чем выход в пену хотя и больше, чем по варианту откачивания металла из под пены..

Статистика промышленных плавок подтвердила целесообразность удаления мышьяка с марганцем в присутствии остаточного железа с обработкой древесными опилками [19, 26, 30].

В табл. 1.32 приведены среднемесячные показатели центробежного рафинирования чернового олова. Статистическая обработка таких результатов за три года показала, что выход олова в съемы на один процент суммы $(\mathrm{Fe}+\mathrm{As})$ в черновом металле связан с абсолютной величиной арифметической разницы процентного содержания (Fe + As) следующим соотношением:

$$
B_{\mathrm{Sn}} /(\mathrm{Fe}+\mathrm{As})=5,91-1,86 \cdot \Delta,
$$

где $B_{\mathrm{Sn}} /(\mathrm{Fe}+\mathrm{As})$ - приведенный выход олова в съемы, \% (отнесенный к сумме, \% ( $\mathrm{Fe}+\mathrm{As})$ в черновом олове); $\Delta$ - абсолютная величина арифметической разницы процента содержания ( $\mathrm{Fe}+\mathrm{As})$ в черновом олове); $B_{\mathrm{Sn}}-$ выход олова в съемы, \%; (Fe + As) - к сумме процента содержания $(\mathrm{Fe}+\mathrm{As})$ в черновом олове.

Промышленные плавки по рафинированию чернового олова от железа и мышьяка проводились на аппарате ЦП-450 (рис. 1.44) [31]. 
Та бли ц а 1.32

Среднемесячный выход олова и примесей в съемы центробежного рафинирования

\begin{tabular}{|c|c|c|c|c|c|c|c|}
\hline \multirow{2}{*}{ Месяц } & \multicolumn{2}{|c|}{ Содержание в черновом олове, $\%$} & \multicolumn{4}{|c|}{ Содержание в съемах, \% } \\
\cline { 2 - 8 } & $\mathrm{Fe}$ & $\mathrm{As}$ & $\mathrm{Fe} / \mathrm{As}$ & $\mathrm{Sn}$ & $\mathrm{As}$ & $\mathrm{Fe}$ & $\mathrm{Sn} /(\mathrm{Fe}+\mathrm{As})$ \\
\hline $\mathrm{I}$ & 1,14 & 0,73 & 1,6 & 61,9 & 5,1 & 7,9 & 4,8 \\
\hline II & 0,53 & 0,57 & 0,9 & 67,3 & 6,3 & 5,8 & 5,6 \\
\hline III & 0,67 & 0,67 & 1,0 & 64,8 & 6,8 & 6,8 & 4,8 \\
\hline IV & 0,67 & 0,72 & 0,9 & 66,2 & 6,8 & 6,9 & 4,8 \\
\hline $\mathrm{V}$ & 0,68 & 0,67 & 1,0 & 67,1 & 6,65 & 6,6 & 5,1 \\
\hline $\mathrm{VI}$ & 0,6 & 0,55 & 1,1 & 69,6 & 6,36 & 5,8 & 5,7 \\
\hline $\mathrm{VII}$ & 0,49 & 0,48 & 1,0 & 67,2 & 5,7 & 5,7 & 5,9 \\
\hline VIII & 0,59 & 0,7 & 0,8 & 56,3 & 6,96 & 5,8 & 4,4 \\
\hline IX & 0,4 & 0,5 & 0,8 & 65,8 & 6,3 & 5,1 & 5,8 \\
\hline X & 0,52 & 0,67 & 0,8 & 70,1 & 7 & 5,5 & 5,6 \\
\hline XI & 0,16 & 0,63 & 0,3 & 62,6 & 6,5 & 5,4 & 5,3 \\
\hline XII & 0,74 & 0,61 & 1,2 & 64,2 & 6,1 & 7,1 & 4,9 \\
\hline
\end{tabular}

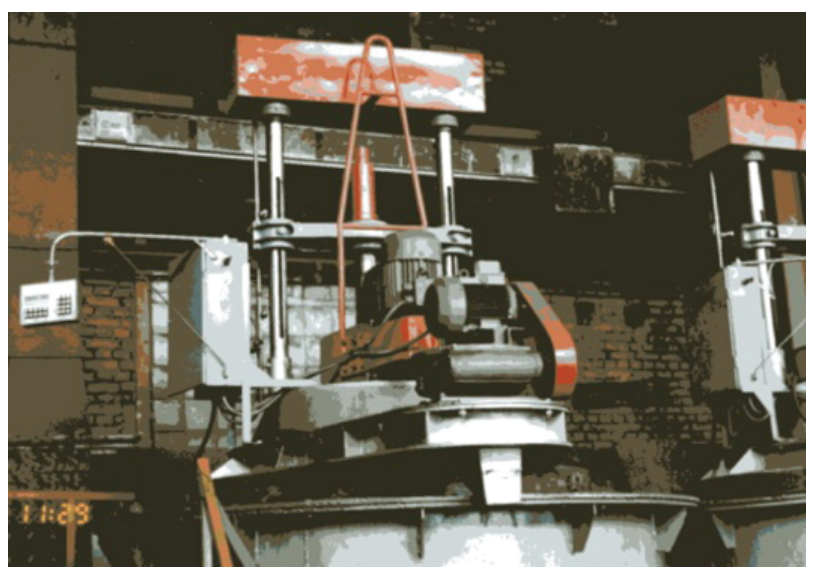

Рис. 1. 44. Центрифуга модели ЦП-500для отходов сплавов

Технология рафинирования олова центробежной фильтрацией с автоматической разгрузкой съемов (рис. 1.45) значительно улучшают условия труда при сравнении с традиционной ручной разгрузкой съемов 
(рис. 1.21). После промышленных испытаний способ и аппарат центробежной фильтрации внедрен и освоен на Новосибирском оловянном комбинате для очистки олова от железа и мышьяка и на заводе Рязцветмет для очистки оловянно-свинцовых сплавов от меди [33]. Экспонат центрифуги выставлялся на международных выставках и отмечен серебряной медалью в Брюсселе (1995 г.).

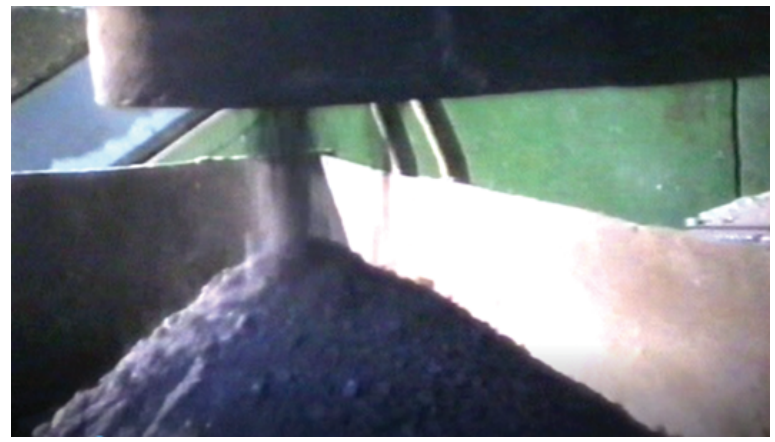

Рис. 1.45. Разгрузка сбемов из фильма демонстрации японским специалистам

Аппарат центробежной фильтрации запатентован в странах: Пат. (США), № 3780864; пат. (ФРГ), № 2206475; пат. (Англия), № 1385799; пат Австралии № 523907; пат Мексики № 178556; пат Испании № 463679.

По лицензиям центробежная фильтрация и вакуумная дистилляция олова успешно используются мексиканской фирмой «Эстаньо-Электра» и комбинатом в Фрайберге. Центробежная фильтрация внедрена также боливийской «Корпорацией «Енаф» и австралийской фирмой «Австралиан Тин Смелгерс» [74].

\subsection{0. Поведение примеси индия при центробежном рафинировании олова}

После восстановительной плавки получают черновое олова с содержанием, мас. \%: 0,1-0,4 Fe; 0,1-1 As; 0,1-0,4 Cu; 0,05-0,3 Sb; 0,01-0,04 Bi; 0,05-1 Pb; 0,002-0,006 In. Несмотря на то, что содержание индия [75] в черновом олове после плавки концентрация индия достигает $0,02 \%$, а в отрафинированном олове содержание индия остается 0,003-0,005\%. Индий и редкие металлы в основном концентрируются в возгонах электровлавки и пылях фьюмингования [76]. С целью повышения извлечения индия предлагалось [77] исходные материалы смешивать с хлорсодержащим реагентом, взятым в соотношении хлор-индий, как (6-22):I, 
и плавить на шлаке с кислотностью 1,5-2,8. Возгоны, пыли, съемы для повышения концентрирования индия подвергают отдельной восстановительной электроплавке с концентрированием индия [78]. Для этого цинксодержающую пыль смешивают с железосодержащим оловянным концентратом до соотношения в шихте цинка к железу в пределах 0,6-2, а плавку ведут на шлаковой ванне с соотношением двуокиси кремния к сумме окиси кальция и закиси железа, равном $0,5-1,2$, и закиси железа к окиси кальция, равном 0,6-1. После плавки пылей, съемов и оборотов в олове концентрируется свинец и индий.

Предлагалось также [79] с целью концентрирования индия в черновом олове пыль окатывают в гранулы с раствором соды, шихту перед расплавлением выдерживать при $700-900^{\circ} \mathrm{C}$, а после расплавления шихты в расплав вводят известь. Значительное повышение извлечения индия при рафинировании олова достигнуто с освоением вакуумного рафинирования с выводом свинца, висмута, индия в конденсат возгонов [80], при котором вакуумную дистилляцию проводят сначала при температуре $900-1150^{\circ} \mathrm{C}$ до остаточного содержания свинца $0,1-1,0$ вес. \%, а затем, после отделения полученного свинцово-висмутового возгона, при температуре $200-1600^{\circ} \mathrm{C}$. В работе [81] для концентрирования индия предложено в качестве анодной ванны использовать приемную ванну расплава конденсата из вакуумной печи, содержащего свинец, висмут и индий. Катодная ячейка выполнена в виде перфорированного цилиндра, обтянутого диафрагмой из кварцевой ткани.

Как приведено в работе [44] показана целесообразность извлечения индия из первичного непрерывного потока конденсата путем погружения электроэкстрактора с катодом в диафрагме непосредственно в ванну конденсата вакуумного аппарата. При этом снижением потерь индия при вакуумном рафинировании олова достигнуто извлечение $92,8 \% \mathrm{In}$ из сплава конденсата (служащего анодом) с получением сплава со свинцом с содержанием индия $32,4 \%$. Несмотря на значительную степень концентрирования индия на вакуумной операции в целом извлечение индия из сырья не превышает $30 \%$.

Дефицит и высокая стоимость индия вызывают необходимость рассмотреть влияние изменение технологии рафинирования олова на причины его потери. Массив 170 промышленных плавок рафинирования олова различного состава обработан статистической программой Exel. По базе плавок с анализами съемов, исходного и полученного олова видно, что содержание индия в съемах выше, чем в исходном олове. Взаимная растворимость индия в олове по эвтектическому типу полагает, что в съемах содержание индия относительно содержанию олова должна 
быть таким же, как в исходном олове. Для сравнения степени концентрирования использован показатель содержания индия относительно олова в съемах $(\mathrm{In} / \mathrm{Sn})$. По коэффициенту наклона корреляционной прямой $k=0,11$ видно, что наибольшее влияние на потери индия оказывает Sb. Относительное соотношение ( $\mathrm{In} / \mathrm{Sn})_{\mathrm{c}}$ прямо зависит от содержания $\mathrm{Sb}$ в металле:

$$
(\mathrm{In} / \mathrm{Sn})_{\mathrm{c}}=0,11 \cdot \mathrm{Sb}+0,01 \text { с коэффициентом корреляции 0,7. }
$$

На связь с индием влияет соединение $\mathrm{Cu}_{3} \mathrm{Sb}$, между элементами которого выявляется связь с корреляцией 0,94. Причем, при меньшем содержании $\mathrm{Sb}<0,2$ влияние $\mathrm{Sb}$ на выход индия в съемы меньше.

При $<0,2 \% \mathrm{Sb}(\mathrm{In} / \mathrm{Sn})_{\mathrm{c}}=0,06 \cdot[\mathrm{Sb}]+0,02$ с корреляции 0,05.

При содержании сурьмы более $>0,24 \% \mathrm{Sb}$ относительная концентрация индия в большей степени зависит от содержания сурьмы в металле:

$$
(\mathrm{In} / \mathrm{Sn})_{\mathrm{c}}=0,12 \cdot[\mathrm{Sb}]-0,0002 \text { с коэффициентом корреляции 0,72. }
$$

Анализ выявил корреляционную связь выхода индия в съемы от содержания мышьяка в металле. При рафинировании олова от мышьяка относительное содержание индия в съемах ( $\mathrm{In} / \mathrm{Sn})$ с прямо зависит от содержания As в металле:

$(\mathrm{In} / \mathrm{Sn})_{\mathrm{c}}=0,069 \cdot[\mathrm{As}]+0,002$ с коэффициентом корреляции 0,75.

В интервале концентраций 0,3-1,6\% As в олове относительное содержание индия выше среднего:

$$
(\mathrm{In} / \mathrm{Sn})_{\mathrm{c}}=0,077 \cdot[\mathrm{As}]-0,005 \text { с коэффициентом корреляции 0,7. }
$$

Остаточный мышьяк As $<0,2 \%$ в олове удаляется с марганцем и при этом интервале $0,04-0,2 \%$ As относительное содержание:

$$
(\mathrm{In} / \mathrm{Sn})_{\mathrm{c}}=0,06 \cdot[\mathrm{As}]+0,01 \text { с коэффициентом корреляции 0,22. }
$$

Несколько меньшее влияние к $=0,03$ оказывает концентрация меди в исходном металле. Относительное содержание (In/Sn) прямо зависит от $\mathrm{Cu}$ по уравнению:

$$
(\mathrm{In} / \mathrm{Sn})_{\mathrm{c}}=0,03 \cdot[\mathrm{Cu}]+0,02 \text { с коэффициентом корреляции 0,64. }
$$


Для уточнения результатов наблюдения и статистической обработки промышленных плавок проведены по указанной методике опыты (табл. 1.33) по центробежной фильтрации олова. Для сопоставления олова с разным содержанием индия в статистике использован коэффициент концентрирования $\operatorname{In}_{\mathrm{c}} / \mathrm{In}_{\mathrm{m}}$, который показывает связан ли индий в съемах в соединениях [82].

Таблица 1.33

Поведение индия при центробежной фильтрации олова

\begin{tabular}{|c|c|c|c|c|c|c|c|c|c|c|c|}
\hline \multirow{2}{*}{$\begin{array}{l}\text { № } \\
\Pi / \Pi\end{array}$} & \multicolumn{3}{|c|}{ Состав металла, \% } & \multicolumn{3}{|c|}{$\begin{array}{c}\text { Состав дроссов, } \\
\%\end{array}$} & \multirow{2}{*}{$\begin{array}{c}\text { Выход } \\
\text { съе- } \\
\text { мов, } \\
\%\end{array}$} & \multicolumn{2}{|c|}{$\begin{array}{c}\text { Степень } \\
\text { очистки, \% }\end{array}$} & \multirow{2}{*}{$\begin{array}{l}\text { По- } \\
\text { тери, } \\
\% \text { Inc }\end{array}$} & \multirow{2}{*}{ Inc/Inm } \\
\hline & As & $\mathrm{Sb}$ & In & As & $\mathrm{Sb}$ & In & & As & $\mathrm{Sb}$ & & \\
\hline 1 & 0,192 & 0,144 & 0,011 & 8,87 & 1,60 & 0,31 & 0,58 & 26,6 & 0,58 & 0,58 & 29,5 \\
\hline 2 & 0,142 & 0,136 & 0,009 & 7,18 & 1,29 & 0,25 & 1,13 & 47,4 & 1,13 & 1,13 & 28,7 \\
\hline 3 & 0,103 & 0,130 & 0,0075 & 5,12 & 0,92 & 0,15 & 1,67 & 61,8 & 1,64 & 1,58 & 20,1 \\
\hline 4 & 0,077 & 0,127 & 0,007 & 4,05 & 0,73 & 0,10 & 2,17 & 72,3 & 2,09 & 1,94 & 14,8 \\
\hline 5 & 0,058 & 0,126 & 0,0064 & 3,65 & 0,66 & 0,08 & 2,63 & 81,1 & 2,50 & 2,24 & 12,9 \\
\hline 6 & 0,042 & 0,127 & 0,0062 & 3,39 & 0,61 & 0,07 & 3,08 & 88,9 & 2,89 & 2,50 & 11,7 \\
\hline 7 & 0,024 & 0,128 & 0,0061 & 3,20 & 0,58 & 0,07 & 3,50 & 95,9 & 3,26 & 2,75 & 10,9 \\
\hline 8 & 0,010 & 0,130 & 0,0060 & 2,90 & 0,52 & 0,06 & 3,88 & 98,7 & 3,60 & 2,97 & 9,8 \\
\hline
\end{tabular}

Примечание. Навеска 50 кг металла состава: $\mathrm{Fe}-0,06$; $\mathrm{As}-0,2 ; \mathrm{Sb}-0,15$; In-0,011; $\mathrm{Pb}-3 ; \mathrm{Bi}-0,1 ; \mathrm{Cu}-0,1$. Расход марганца $\mathrm{Mn} / \mathrm{As}=1,6$ в виде оловянной лигатуры с 8,5\% Mn.

Металл фильтровался при $350^{\circ} \mathrm{C}$ с добавкой 50 г древесных опилок. Параметр $I n_{c} / I_{m}=(I n / S n)_{c}:(I n / S n)_{m}$ характеризует коэффиииент распределения индия.

Опыты подтвердили 10-20-кратное концентрирование индия в мышьяковистых съемах рафинирования, что предполагает со кристаллизацию соединений с твердыми соединениями мышьяка. Такое поведение индия при фильтрации олова можно объяснить образованием интерметаллических соединений, составы которых приведен в табл. 1.33 по данным [82]. Статистическая обработка опытов показывает, что содержание индия в съемах выше, чем в исходном олове. Параметр $K$ связи характеризует коэффициент корреляции связи в массиве состава металла для возможных фаз интерметаллических соединений с температурами плавления по диаграммам состояния двухфазных систем. В табл. 1.34 приведено сравнение показателя связи. 
Таблица 1.34

Сравнение влияния интерметаллидов в олове на выход индия съемы

\begin{tabular}{|c|c|c|c|c|c|}
\hline \multicolumn{2}{|c|}{ Фазы соединений индия } & \multirow{2}{*}{ К связи } & \multicolumn{2}{|c|}{ Конкурирующие фазы } & \multirow{2}{*}{ К связи } \\
\cline { 1 - 1 } фазы & $T_{\text {пл }},{ }^{\circ} \mathrm{C}$ & & фазы & $T_{\text {пл }},{ }^{\circ} \mathrm{C}$ & \\
\hline $\mathrm{InSb}$ & 525 & 0,42 & $\mathrm{Cu}_{3} \mathrm{Sb}$ & 684 & 0,8 \\
\hline $\mathrm{InCu}_{3}$ & 667 & 0,24 & $\mathrm{Cu}_{3} \mathrm{As}$ & 830 & 0,76 \\
\hline $\mathrm{InAs}$ & 942 & 0,37 & $\mathrm{FeAs}$ & 1030 & 0,11 \\
\hline & & & $\mathrm{Mn}_{2} \mathrm{As}$ & 1029 & 0,13 \\
\hline & & & $\mathrm{SnAs}$ & 605 & 0,25 \\
\hline & & & $\mathrm{FeSn}$ & 740 & 0,1 \\
\hline
\end{tabular}

Снижению образования соединений индия могут способствовать образование конкурирующих интерметаллических соединений по реакциям.

$$
\begin{gathered}
\mathrm{InAs}+\mathrm{SnMn}=\mathrm{Mn}_{2} \mathrm{As}+\mathrm{Sn}(\mathrm{In})+\Delta Z_{300}=-53,8 \text { кДж/мол; } \\
\mathrm{InAs}+\mathrm{FeSn}=\mathrm{FeAs}+\mathrm{Sn}(\mathrm{In})+\Delta Z_{300}=-53 \text { кДж/мол; } \\
\mathrm{InAs}+\mathrm{Sn}=\mathrm{SnAs}+\mathrm{In}+(\mathrm{Sn})+\Delta Z_{300}=-15,7 \text { кДж/мол; } \\
\mathrm{InSb}+\mathrm{Sn}(\mathrm{Cu})=\mathrm{Cu}_{3} \mathrm{Sb}+\mathrm{Sn}(\mathrm{In})+\Delta Z_{300}=-11,6 \text { кДж/мол. }
\end{gathered}
$$

Образование конкурирующих интерметаллических соединений $\mathrm{FeAs}, \mathrm{MnAs}, \mathrm{Cu}_{3} \mathrm{Sb}$ могут снижать выход индия в съемы.

Статистический анализ производственных плавок выявил корреляционную связь выхода индия в съемы от содержания сурьмы и мышьяка в металле. Образование конкурирующих интерметаллических соединений $\mathrm{FeAs}, \mathrm{MnAs}, \mathrm{Cu}_{3} \mathrm{Sb}$ могут снижать влияние состава металла на выход индия в съемы. Анализом поведения индия при фильтрации олова показан, что описанный вариант технологии является оптимальный по извлечению индия. Оптимум фильтрации от As c Fe сначала при $500^{\circ} \mathrm{C}$, для более полного удаления высокотемпературных соединений мышьяка с последующим снижением до $350^{\circ} \mathrm{C}$ для зачистки остаточных кристаллов интерметаллидов. 


\subsection{1. Психодогические особенности разработки И освоения новой техники}

Освоение новой техники сопровождается многочисленными препятствиями. Любые трудности и недостки используются коллегами по интуитивным личным мотивам оффициально препятствовать освоению. Для успеха дела изобретателю-менеджеру нужно обладать терпением и умением неконфликтно привлекать на свою сторону, убеждать противников к совершенствованию процессов, превращать идею в коллективное творчество. Таким умением, талантом обладал начальник цеха Сутурин С.Н.. Он увлек в творческий процесс механика Бауэр Е.Т., электрика Перкис Л.В., слесаря Деева С.Л., и других работников.

Тем не менее, изобретателю необходима объективная оппозиция. Изобретатель, как правило, слепо верит в идею и это может завести или в тупик или излишние экономические затраты. Критические действия оппозиции и противников вынуждает автора не допускать самоуспокоения и принуждают к действию к устранению недостатков. Сутурин С.Н. отличался тем, что шел на контакты, вовлекал в дискуссию с любым оппонентом.

Равновесие творческой личности и добродушной оппозиции движет прогрессом. Однако, естественный ход времени и противники с личными мотивами увлекают членов творческого коллектива новыми предложениями, реорганизацией, упрощением регламентов, повышением по служебной лестнице постепенно разрушают творческий коллектив. В случае если новая техника уже достаточно отлажена, то сможет работать без ее «родителей». Например, новое молодое поколение рафинировщиков невозможно заставить работать как на (рис. 1.21) и будет стремиться работать на центрифуге (рис. 1.44). Значит, идея продолжает жить, но его нужно непрерывно совершенствовать. Для этого будет полезна настоящая обзорная монография. 


\section{Гдава 2. РАФИНИРОВАНИЕ СВИНЦА ЦЕНТРОБЕЖНОЙ ФИЛЬТРАЦИЕЙ РАСПЛАВА}

\section{1. Грубое обезмеживание}

В производстве цветных металлов после восстановительной плавки свинцовых концентратов получают металл с сопутствующими примесями: $1-5 \% \mathrm{Cu} ; 0,2-2 \% \mathrm{As} ; 0,5-2 \% \mathrm{Sb} ; 0,1-0,25 \mathrm{Sn} ; 0,05-0,4 \% \mathrm{Bi}$; $0,1-0,3 \% \mathrm{~S} ; 1-5 \mathrm{Kr} / \mathrm{T} \mathrm{Ag} ; 1-30$ г/т Au [1.2] и это вызывает необходимость их удаление рафинированием.

По традиционной технологии ликвационного обезмеживания свинца после снижения температуры до $400^{\circ} \mathrm{C}$ шумовками снимают медистые шликера. Выход шликеров составляет 10-30\%, в них переходит до 9-22\% РЬ. Остаточную медь (до содержания $0,005 \%$ ) удаляют после вмешивания $0,5-1$ кг/т элементарной серы и охлаждения до $340-345^{\circ} \mathrm{C}$. Выход сульфидных шликеров составляет 3-5\%, они содержат 1-5\% Cu, 3-4\% S [2.2].

В производстве олова разработан способ [3.2] центробежной фильтрации олова аппараты рафинирования от железа, мышьяка и меди. Инциатива распространения опыта фильтрации олова на другие металлы одобрена Минцветметом [4.2] работа по оценке возможности центробежной фильтрации продолжена на операциях рафинирования свинца. Для этого на Новосибирский оловокомбинат со свинцовых заводов поставлен черновой свинец в слитках. Для испытания способа разработана и испытана опытная модель лабораторной центрифуги для разделения суспензии [5.2]. В центрифугу (рис. 2.1) заливают суспензию расплав чернового свинца в приемную воронку. Жидкий металл под действием центробежных сил продавливается через щелевой канал между диском и ротором в кольцевой приемник. Осадок шнеком транспортируется в окно. Опыты проведены на центрифуге модели [5.2; 6.2].

Испытания фильтрации свинца на центрифуги с заливным фильтром указанной конструкции [5.2; 6.2] показали высокую степень удаления меди $(97 \%)$ и мышьяка $(77,5 \%)$ в шликера грубого обезмеживания. Однако, испытания показали недостатки в эксплуатации и монтаже центрифуги. Для проведения процесса фильтрации требуется сопряжения точности поддержания температур миксера исходного свинца и щелевого канала, окна разгрузки и слива. При отклонениях требуется повторные операции. Кроме того, щелевой канал зарастает особенно при фильтрации олова. Изготовление и замена узлов вызывает значительные 
сложности. Остаются сомнения в возможности значительного увеличения диаметра фильтра центрифуги.

С этой точки зрения более перспективным оказался вариант лабораторной центрифуги с фильтром погружаемым в рафинируемый расплав первой модели (рис. 1.5) [7.2; 17].

Таблица 2.1 Материальный баланс процесса центробежной фильтрации чернового свинца

\begin{tabular}{|l|c|c|c|c|c|c|c|c|c|c|}
\hline \multirow{2}{*}{ Статьи } & \multirow{2}{*}{\begin{tabular}{c}
\multirow{2}{*}{ Вес, } \\
кг
\end{tabular}} & $\begin{array}{c}\text { Выход, } \\
\%\end{array}$ & \multicolumn{4}{|c|}{ Содержание, \% } & \multicolumn{5}{|c|}{ Распред, \% } \\
\hline Загружено: & & & & & & & & & & \\
\hline Черновой $\mathrm{Pb}$ & 57,5 & 100 & 93,5 & 3,5 & 1,3 & 0,8 & 100 & 100 & 100 & 100 \\
\hline Получено: & & & & & & & & & & \\
\hline $\begin{array}{l}\text { Фильтрован- } \\
\text { ный Рb }\end{array}$ & 49,7 & 86,4 & 99,2 & 0,06 & 0,10 & 0,6 & 91,8 & 1,4 & 6,9 & 64,8 \\
\hline Шликера & 7,6 & 13,2 & 49,8 & 25,3 & 7,5 & 1,1 & 7,0 & 97,0 & 77,5 & 17,5 \\
\hline Невязка & $-0,2$ & 0,3 & & & & & 1,2 & 1,6 & 15,6 & 17,6 \\
\hline
\end{tabular}

Примечание. Температура фильтрации $340^{\circ} \mathrm{C}$.

В котел объемом 10 л загружали навеску чернового свинца. Включали электрообогрев и температуру свинца в котле повышали до $600^{\circ} \mathrm{C}$. При этой температуре расплав свинца перемешивали и отбирали пробу для анализа исходного состава. Температуру снижали до заданной и производили рафинирование свинца. Во время рафинирования ротор центрифуги погружали в расплав свинца на глубину 10-30 мм, обеспечивающую полное покрытие расплавом тарелей во время их вращения. Вращение ротора в расплаве производится со скоростью 100-200 об/ мин в течение 1-5 мин. После наполнения кристаллами полости между тарелями ротор поднимали над поверхностью расплава и увеличивали скорость его вращения до 1500-3000 об/мин. В течение 20-30 с происходила «сушка» кристаллов, т.е. полное удаление из него жидкого расплава свинца, затем вращение фильтра останавливали. Верхнюю тарель освобождали и поднимали ее по оси вверх так, чтобы дать доступ к съемам, оставшимся на нижней тарели. С помощью ручного скребка удаляли съемы с внутренней поверхности нижней тарели, верхнюю тарель опускали вниз и снова закрепляли. Центрифуга была готова к следующему циклу рафинирования. Погружение ротора в расплав, «сушку» съемов, выгрузку их продолжали до полного удаления твердой фазы от расплава 
чернового свинца, что определялось визуально по отсутствию осадка в тарелях, затем отбирали пробы конечных продуктов: свинца и съемов [8.2]. Укрупненные опыты с навесками 50-100 кг проводили центрифугой [9.2], применяемой для фильтрации оловянных припоев. Полупромышленные испытания проводили на центрифуге ПАФВС-650 (рис 1.9) применяемой при рафинировании олова и описанной в работе [10.2].

Для проверки возможности использования центробежной фильтрации для рафинирования свинца были проведены поисковые опыты с черновым свинцом Усть-Каменогорского свинцово-цинкового комбината. Опыты проведены на лабораторной погружной центрифуге (рис. 2.1) с навесками в среднем 50 кг чернового свинца. В табл. 2.2 показаны результаты опытов по грубому обезмеживанию свинца.

Та блица 2.2

Результаты поисковых опытов грубого обезмеживания свинца УКСЦК

\begin{tabular}{|c|c|c|c|c|c|c|c|c|c|c|}
\hline \multicolumn{2}{|c|}{$\begin{array}{c}\text { Состав, \%, } \\
\text { исх. } \mathrm{Pb}\end{array}$} & \multicolumn{2}{|c|}{$\begin{array}{c}\text { Состав, \%, } \\
\text { раф. } \mathrm{Pb}\end{array}$} & \multicolumn{3}{|c|}{$\begin{array}{l}\text { Состав, \%, } \\
\text { шликеров }\end{array}$} & \multirow{2}{*}{$\mathrm{Cu} / \mathrm{As}$ at is } & \multicolumn{2}{|c|}{$\begin{array}{c}\text { Степень, \%, } \\
\text { удален. }\end{array}$} & \multirow{2}{*}{$\mathrm{Pb} / \mathrm{CuAs}$ шлик } \\
\hline $\mathrm{Cu}$ & As & $\mathrm{Cu}$ & As & $\mathrm{Cu}$ & As & $\mathrm{Pb}$ & & $\mathrm{Cu}$ & As & \\
\hline 1,07 & 0,37 & 0,21 & 0,11 & 20,8 & 8,0 & 63,6 & 3,32 & 80,0 & 80,7 & 2,21 \\
\hline 1,1 & 0,40 & 0,18 & 0,12 & 27,2 & 10,4 & 56,7 & 3,17 & 84,0 & 88,7 & 1,51 \\
\hline 1,4 & 0,51 & 0,22 & 0,16 & 24,4 & 9,3 & 56,7 & 3,17 & 84,0 & 87,4 & 1,68 \\
\hline 1,55 & 0,65 & 0,046 & 0,20 & 32,5 & 12,4 & 40,3 & 2,76 & 97,0 & 89,1 & 0,90 \\
\hline 2,1 & 0,81 & 0,21 & 0,26 & 29,4 & 11,2 & 51,7 & 2,96 & 90,0 & 77,4 & 1,27 \\
\hline 2,34 & 0,93 & 0,18 & 0,30 & 28,6 & 10,9 & 54,1 & 2,90 & 92,0 & 89,0 & 1,37 \\
\hline 2,7 & 1,06 & 0,24 & 0,34 & 28,9 & 11,0 & 53,3 & 2,93 & 91,0 & 85,8 & 1,33 \\
\hline 3,9 & 1,64 & 0,06 & 0,56 & 28,4 & 10,9 & 52 & 2,73 & 98,0 & 86,1 & 1,32 \\
\hline
\end{tabular}

Примечание. Навески 50 кг. Температура фильтрации $400^{\circ} \mathrm{C}$.

При исходном содержании в свинце более $1 \%$ меди выход шликеров ( Vix) изменяется по уравнению:

$$
V i x=2,9 \cdot[\mathrm{Cu}]+0,72 \text { с корреляцией 0,93. }
$$

При среднем содержании 2,1\% меди получается отрафинированный свинец со средним содержанием $0,2 \%$ меди со средним удельным выходом свинца в шликера $\mathrm{Pb} / \mathrm{Cu}=1,9$. 
Таблица 2.3 Результаты грубого обезмеживания чернового свинца завода «Электроцинк»

\begin{tabular}{|c|c|c|c|c|c|c|c|c|c|c|c|}
\hline \multicolumn{2}{|c|}{$\begin{array}{c}\text { Черновой } \\
\text { свинец }\end{array}$} & \multicolumn{2}{|c|}{$\begin{array}{c}\text { Рb рафи- } \\
\text { нирован- } \\
\text { ный }\end{array}$} & \multicolumn{3}{|c|}{$\begin{array}{c}\text { Состав шлике- } \\
\text { ров, } \%\end{array}$} & \multirow[t]{2}{*}{$\mathrm{Cu} / \mathrm{As}$ at is } & \multicolumn{2}{|c|}{$\begin{array}{l}\text { Степень } \\
\text { удален. }\end{array}$} & \multirow{2}{*}{$\begin{array}{l}\text { Потери } \\
\mathrm{Pb} / \mathrm{CuAs}\end{array}$} & \multirow{2}{*}{$K_{\text {perp }}$ As $/ \mathrm{As}_{\mathrm{s}}$} \\
\hline $\mathrm{Cu}$ & As & $\begin{array}{c}\mathrm{Cu}, \\
\%\end{array}$ & $\begin{array}{c}\text { As, } \\
\%\end{array}$ & $\mathrm{~Pb}$ & $\mathrm{Cu}$ & As & & $\begin{array}{c}\mathrm{Cu}, \\
\%\end{array}$ & $\begin{array}{c}\text { As, } \\
\%\end{array}$ & & \\
\hline 0,7 & 0,7 & 0,068 & 0,38 & 66,9 & 10,5 & 5,67 & 1,15 & 90 & 48,6 & 4,1 & 14,9 \\
\hline 0,95 & $\mid 0,49$ & 0,068 & 0,2 & 66,52 & $\mid 14,9$ & 5,17 & 2,22 & 94,4 & 63,3 & 3,3 & 25,9 \\
\hline 1,05 & 0,68 & 0,048 & 0,16 & 69,8 & 14,3 & 7,53 & 1,77 & 95,5 & 77,5 & 3,2 & 47,1 \\
\hline 1,14 & 0,74 & 0,01 & 0,35 & \begin{tabular}{|l|l}
61,87 \\
\end{tabular} & 18,9 & 6,97 & 1,77 & 99,4 & 56,5 & 2,4 & 19,9 \\
\hline
\end{tabular}

Примечание. $(\mathrm{Cu} / \mathrm{As})_{\text {atis }}$ - соотношение атомарного содержание седи и мышьяка в исходном свинце; $K_{\text {рспр }}$-коэффициент распределения мышьяка равный соотношению содержания в тведых иликерах к содержанию в отрафинированном свинце $A s / A s_{j}$

При среднем содержании $1,5 \%$ меди в исходном свинце завода «Электроцинк» [11.2] получен металл с содержанием 0,03-0,07\% меди. Средний состав шликеров $16,2 \%$ меди, 57,9\% свинца. Относительный средний выход свинца в шликера $\mathrm{Pb} / \mathrm{Cu}=3,6$.

С повышением содержания меди в исходном свинце относительный выход свинца в шликера снижается по уравнению:

$$
\mathrm{Pb} / \mathrm{Cu}=8-3 \cdot[\mathrm{Cu}] \text { с корреляцией } 0,7 \text {. }
$$

где $[\mathrm{Cu}]$ весовая концентрация меди в исходном свинце; $\mathrm{Pb} / \mathrm{Cu}-$ выход свинца относительно количеству удаляемой примеси.

Таблица 2.4 Результаты поисковых опытов грубого обезмеживания свинца завода Укрцинк

\begin{tabular}{|c|c|c|c|c|c|c|c|c|c|c|c|c|}
\hline \multicolumn{2}{|c|}{$\begin{array}{c}\text { Черновой } \\
\text { свинец }\end{array}$} & \multicolumn{3}{c|}{$\begin{array}{c}\text { Рb рафинирован- } \\
\text { ный }\end{array}$} & \multicolumn{3}{c|}{ Состав шликеров, \% } & \multicolumn{2}{c|}{$\begin{array}{c}\text { Степень } \\
\text { удаления }\end{array}$} & Потери \\
\hline $\mathrm{Cu}$ & $\mathrm{As}$ & $\mathrm{Sb}$ & $\begin{array}{c}\mathrm{Cu}, \\
\%\end{array}$ & $\begin{array}{c}\mathrm{As}, \\
\%\end{array}$ & $\begin{array}{c}\mathrm{Sb}, \\
\%\end{array}$ & $\mathrm{~Pb}$ & $\mathrm{Cu}$ & $\mathrm{As}$ & $\mathrm{Sb}$ & $\begin{array}{c}\mathrm{Cu}, \\
\%\end{array}$ & $\begin{array}{c}\mathrm{As}, \\
\%\end{array}$ & $\mathrm{~Pb} / \mathrm{CuAs}$ \\
\hline 0,74 & 0,16 & 2,81 & 0,15 & 0,17 & 2,56 & 76 & 8,65 & 0,1 & 6,21 & 81,4 & 3,44 & 8,69 \\
\hline 0,82 & 0,11 & 2,9 & 0,12 & 0,1 & 2,64 & 74,55 & 10,2 & 0,15 & 6,45 & 96,7 & 11,6 & 7,20 \\
\hline 1,03 & 0,09 & 3,18 & 0,15 & 0,07 & 2,88 & 72,39 & 12,17 & 0,29 & 7,03 & 85,6 & 24,4 & 5,81 \\
\hline
\end{tabular}


Характерной особенностью чернового свинца завода Укрцинк это высокое содержания сурьмы и часть его переходит в медистые шликера.

Выход свинца в шликера объясняется низким содержанием мышьяка и зависит от исходного содержания меди по уравнению:

$$
\mathrm{Pb} /(\mathrm{Cu}+\mathrm{As})=13,62-7,2 \cdot[\mathrm{Cu}]_{i s} \text { с корреляцией 0,9, }
$$

где $[\mathrm{Cu}]_{\text {is }}$ - содержание меди в исходном свинце; $\mathrm{Pb} /(\mathrm{Cu}+\mathrm{As})-$ выход свинца относительно суммы удаленных количеств $\mathrm{Cu}$, As.

На рис. 2.1 показано сравнение относительного выхода свинца в шликера при грубом обезмеживании чернового свинца разных заводов.

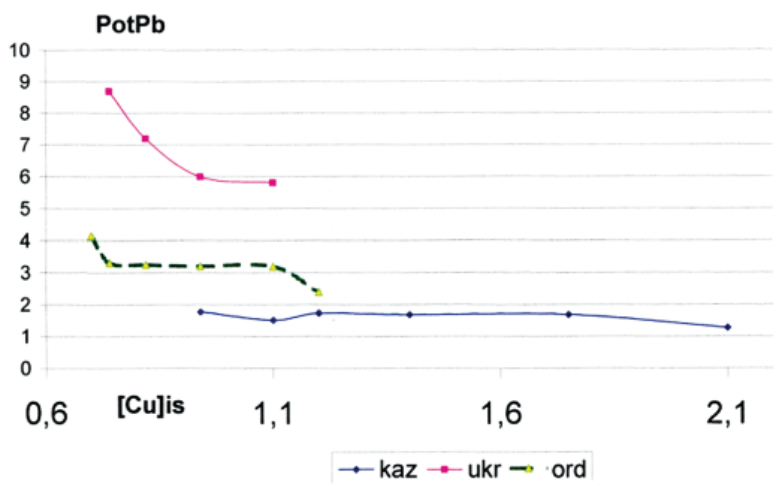

Рис. 2.1. Сравнение относительных потерь свинца при грубом обезмеживании чернового свинца разных заводов.

Обозначения: ордината PotPb - потери свинца в дроссы относительно величине удаляемых примесей $\mathrm{Cu}+A s ;$ абсиисса - [Cu]is - содержание Си в исходном черновом свинце kaz - завода УКСЦЗ; иkr - завода Укриинк; ord - завода «Электроцинк»

Особенностью чернового свинца завода УКСЦК является высокое содержание мышьяка, который удаляется с медью в шликера. Выход свинца в шликера зависит от соотношения $\mathrm{Cu} / \mathrm{As}$ по уравнению:

$$
\frac{\mathrm{Pb}}{\mathrm{Cu}+\mathrm{As}}=1,58 \cdot(\mathrm{Cu} / \mathrm{As})_{i s}^{a t}-3,27 \text { с корреляцией } 0,75,
$$

где $(\mathrm{Cu} / \mathrm{As})_{i s}^{a t}$ - атомное соотношение $\mathrm{Cu}$, Аs в исходном свинце.

В лабораторных условиях исследовано влияние температуры на результаты центробежного рафинирования, которые приведены в табл. 2.4 [11.2]. Расплавленный черновой свинец массой 53-48 кг подвергали грубому обезмеживанию в процессе центробежного рафинирования при температурах фильтрации $340-550^{\circ} \mathrm{C}$. 
Влияние температуры

на показатели грубого обезмеживания свинца «Электроцинка»

\begin{tabular}{|c|c|c|c|c|c|c|c|c|c|c|}
\hline \multirow[t]{2}{*}{$T_{\text {фил }}$} & \multicolumn{2}{|c|}{$\begin{array}{c}\text { Состав } \\
\text { исходных } \\
\text { металлов }\end{array}$} & \multicolumn{2}{|c|}{$\begin{array}{c}\text { Металлы } \\
\text { отфильтро- } \\
\text { ванные }\end{array}$} & \multicolumn{3}{|c|}{ Состав шликеров } & \multirow[t]{2}{*}{$\mathrm{StCu}$} & \multirow[t]{2}{*}{ StAs } & \multirow[t]{2}{*}{$\begin{array}{c}\text { Шлик. } \\
\mathrm{Pb} /(\mathrm{Cu}+\mathrm{As})\end{array}$} \\
\hline & $\mathrm{Cu}$ & As & $\mathrm{Cu}$ & As & $\mathrm{Cu}$ & As & $\mathrm{Pb}$ & & & \\
\hline 340 & 0,44 & 0,4 & 0,063 & 0,22 & 7,2 & 4,3 & 75,7 & 86,9 & 53,2 & 6,6 \\
\hline 350 & 0,59 & 0,4 & 0,044 & 0,38 & 10,8 & 5 & 72 & 92,8 & 40,9 & 4,6 \\
\hline 370 & 0,84 & 0,74 & 0,024 & 0,38 & 19,8 & 10,4 & 57,4 & 97,2 & 53,9 & 1,9 \\
\hline 400 & 0,76 & 0,52 & 0,07 & 0,32 & 17,8 & 5,5 & 60,7 & 91,2 & 41,1 & 2,6 \\
\hline 400 & 0,73 & 0,35 & 0,053 & 0,28 & 17,38 & 8 & 66,4 & 92,7 & 52,7 & 2,6 \\
\hline 440 & 0,82 & 0,74 & 0,064 & 0,4 & 12,1 & 5,8 & 66,3 & 92,5 & 48,5 & 3,7 \\
\hline 450 & 0,47 & 0,34 & 0,12 & 0,48 & 12,2 & 6,38 & 70,6 & 75,2 & 28,4 & 3,8 \\
\hline 500 & 0,82 & 1,3 & 0,11 & 0,39 & 11,8 & 16 & 69 & 88,2 & 74,0 & 2,5 \\
\hline 550 & 0,55 & 0,47 & 0,06 & 0,22 & 9,8 & 5 & 66,8 & 89,6 & 54,5 & 4,5 \\
\hline
\end{tabular}

После фильтрации черновой свинец содержит 0,03-0,07\% меди. Рафинирование при температуре выше $550^{\circ} \mathrm{C}$ осложняется из-за налипания шликеров на тарелях центрифуги. При температуре ниже $340^{\circ} \mathrm{C}$ повышается выход отфильтрованных шликеров и возрастает содержание в них свинца.

Таблица 2.6 Баланс распределения компонентов при центробежном рафинировании чернового свинца (завода «Электроцинк»)

\begin{tabular}{|c|c|c|c|c|c|c|}
\hline \multirow{2}{*}{ Статьи } & \multirow{2}{*}{$\begin{array}{c}\text { Macca, } \\
\text { Кг }\end{array}$} & \multirow{2}{*}{$\begin{array}{c}\text { Выход, } \\
\%\end{array}$} & \multicolumn{4}{|c|}{ Содержание, \% } \\
\hline & & & $\mathrm{Cu}$ & As & $\mathrm{Sb}$ & $\mathrm{Pb}$ \\
\hline Загружено: Свинец черновой & 49,9 & & 0,82 & 0,74 & 0,36 & 98 \\
\hline Оборотные шликера & 0,95 & & 1,21 & 0,3 & 0,7 & 92,4 \\
\hline \multicolumn{7}{|c|}{ Грубое обезмеживание: } \\
\hline Получено: Свинец рафинированный & 3 & 5,9 & 12,1 & 5,85 & 1,6 & 66,4 \\
\hline Шликера & 47,8 & & 0.05 & 0,4 & 0,28 & \\
\hline \multicolumn{7}{|c|}{ Тонкое обезмеживание: } \\
\hline Оборотные шликера. & 1,2 & 2,5 & 2,3 & 0,87 & 0,64 & \\
\hline Обезмеженный свинец & 46,5 & & 0,005 & 0,37 & 0,35 & 91,6 \\
\hline Извлечение в шликера & & & 92,6 & 48,1 & 26,6 & 2,3 \\
\hline
\end{tabular}


Анализ результатов центробежного рафинирования свинца, полученных в лабораторных условиях, свидетельствует о возможности и целесообразности применения этого процесса в промышленных масштабах на стадии грубого обезмеживания свинца путем поиска путей предотвращения налипания шликеров. Однако, внедрение процесса центробежного рафинирования металла требует многократных испытаний операции рафинирования на конкретных составах жидкого чернового свинца. В поиске вариантов применения центробежной фильтрации в действующее свинцовое производство предложена непрерывная установка использования аппарата центробежной фильтрации [12.2]. Особенность заключается в том что, исходный металл охлаждают заливкой его в ванну с расплавом свинца, имеющим $420-520^{\circ} \mathrm{C}$ и содержащим 0,2-0,5\% меди. Из нижней части ванны выводят отфильтрованный свинец, а из верхней части непрерывно фильтром собирают шликера на установке рис. 2.2.

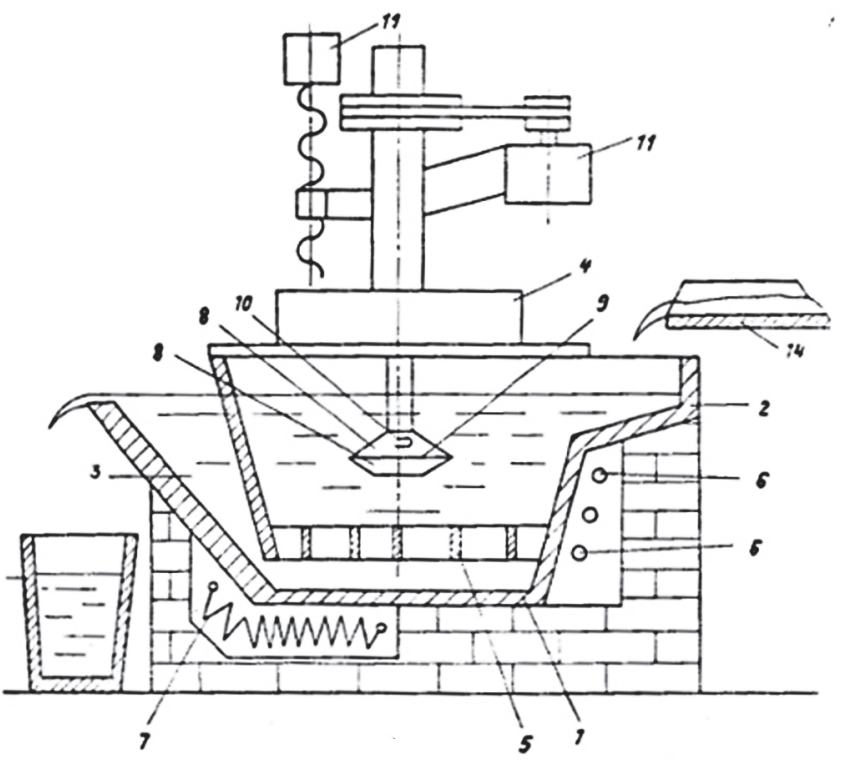

Рис. 2.2. Схема постановки центрифуги на котел непрерывного цикла.

Узлы: 1 - котел; 2 - заливной порог; 3 - сливной порог; 4 - транспортер сбора и разгрузки шликеров; 5-решетка; 6-охлаждение; 7-нагревателб; 8-тарели фильтра; 9 - фильтрующая щель; 10 - заборные окна; 11 - двигатель вращения фильтра; 12 - механизм подбема ротора с фильтром 
Испытания моделирования непрерывного рафинирования свинца проводили ранее описанной полупромышленной центрифугой ЦП-200 [9.2], устанавливаемой на сварном котле. Черновой свинец из печи с температурой $900^{\circ} \mathrm{C}$ и содержащий $0,6-4,5 \%$ меди; $0,5-1,5 \%$ мышьяка заливают в ванну 1 при перемешивании со свинцом с температурой $420-520^{\circ} \mathrm{C}$ и под охлаждением 6. Одновременно с этим в верхней зоне ванны вращают фильтр 8 центрифуги, который захватывает металл со шликерами через окна 10 в полость фильтра. Под действием центробежной силы жидкий свинец продавливается через фильтрующую щель 9, а твердый осадок накапливается в полости фильтра. По мере накопления твердого осадка тарели 8 поднимают над уровнем расплава в зону транспортера 4 , тарели 8 раскрывают и осадок выбрасывают в транспортер 4.

В нижней части ванны 1 , отделенной решеткой 5 , металл охлаждается 6 до температуры $240-380^{\circ} \mathrm{C}$, отстаивается от выделяющихся кристаллов меди до содержания $0,06-0,15 \%$ меди в металле и через сифон 3 сливается в емкость. Опыты моделирования непрерывности рафинирования показали возможности снижения выхода свинца в шликера. Фильтрация при температуре $520^{\circ} \mathrm{C}$ снижает качество отфильтрованного металла. Фильтрация при температуре $420^{\circ} \mathrm{C}$ повышает качество отфильтрованного металла, но повышается выход свинца в шликера. С увеличением доли слива расплава с ванны от 0,3 до 0,5 снижается качество сливаемого металла [13.2]. С целью снижения образования настылей предложено [14.2] исходный расплав с температурой $900-1000^{\circ} \mathrm{C}$, охлаждать путем его смешения в заливочном лотке подачей из котла донного расплава с температурой $350-450^{\circ} \mathrm{C}$.

Для этого в устройстве (рис. 2.3) установлен экран на глубину в 2-3,5 раза превышающий глубину погружениия тарелей фильтра, а лоток соединен тангенциально со средней частью экрана.

Результаты приведены в табл. 2.7.

Установка [14.2] для непрерывного обезмеживания свинца состоит из обогреваемого котла 1, снабженного холодильником 2 и желобом 3 для слива отрафинированного свинца. На котел устанавливается центрифуга 4 с погружаемым фильтром из тарелей 5 , фасонным экраном 6 , в середину которого тангенциально под острым углом врезан цилиндрический лоток 7 для подачи смеси исходного и охлажденного расплавов в зону кристаллизации соединений. Во внешней зоне расплава 10 , расположенной за экраном 6 и служащей своеобразным сифоном для слива очищенного расплава, помещен насос с сифоном 11 для подачи в лоток 7 охлажденного и очищенного металла. Исходный черновой свинец из печи с температурой $900-1000^{\circ} \mathrm{C}$ по желобу заливают в лоток 7 и смешивают с оборотным охлажденным свинцом. Для этого в поток 7 исходного 
металла подают струю охлажденного до $350-450^{\circ} \mathrm{C}$ металла с помощью насоса 11 с донной охлаждаемой зоны. В нижней части ликвационной зоны 9 очищенный от всплывших шликеров металл выводится через сифонную зону 10, отделенную фасонным экраном 6 .

Таблица 2.7

Результаты опытов моделирования цикличной непрерывности грубого обезмеживания свинца

\begin{tabular}{|c|c|c|c|c|c|c|c|c|c|c|}
\hline \multirow[t]{2}{*}{ Операции } & \multirow[t]{2}{*}{$\begin{array}{l}T, \\
{ }^{\circ} \mathrm{C}\end{array}$} & \multirow{2}{*}{$\begin{array}{c}\text { За- } \\
\text { грузка } \\
\text { вес, } \\
\text { кг }\end{array}$} & \multicolumn{2}{|c|}{ Состав, \% } & \multirow{2}{*}{$\begin{array}{c}\text { Полу- } \\
\text { чено } \\
\text { вес, } \\
\text { кг }\end{array}$} & \multicolumn{2}{|c|}{ Состав, $\%$} & \multicolumn{2}{|c|}{$\begin{array}{c}\text { Степень, } \\
\%, \text { очист- } \\
\text { ки от }\end{array}$} & \multirow[t]{2}{*}{$\begin{array}{c}\text { Выход } \\
\mathrm{Pb} /(\mathrm{CuAs})\end{array}$} \\
\hline & & & $\mathrm{Cu}$ & As & & $\mathrm{Cu}$ & As & $\mathrm{Cu}$ & As & \\
\hline Рb ванны & & 90 & 0,5 & 0,15 & & & & & & \\
\hline Черновой $\mathrm{Pb}$ & & 40 & 1,5 & 0,6 & & & & & & \\
\hline Фильтр шликера & 520 & & & & 2,7 & 37 & 11,7 & 95,1 & 84,2 & 1,01 \\
\hline $\mathrm{Pb}$ на сливе & & & & & 37,2 & 0,16 & 0,14 & & & \\
\hline Рb ванны & & 90 & 0,3 & 0,1 & & & & & & \\
\hline Черновой $\mathrm{Pb}$ & & 120 & 1,5 & 0,6 & & & & & & \\
\hline Фильтр шликера & 460 & & & & 6,1 & 31,4 & 10,5 & 92,5 & 79,1 & 1,36 \\
\hline $\mathrm{Pb}$ на сливе & & & & & 114 & 0,1 & 0,12 & & & \\
\hline $\mathrm{Pb}$ ванны & & 90 & 0,2 & 0,1 & & & & & & \\
\hline Черновой $\mathrm{Pb}$ & & 80 & 1,5 & 0,6 & & & & & & \\
\hline Фильтр шликера & 420 & & & & 3,8 & 27 & 9,5 & 74,3 & 63,3 & 1,61 \\
\hline $\mathrm{Pb}$ на сливе & & & & & 76 & 0,06 & 0,1 & & & \\
\hline
\end{tabular}

По мнению авторов [14.2] испытания показали возможность предотвращения настылеобразования путем резкого охлаждения, поступающего чернового свинца с температурой $900^{\circ} \mathrm{C}$ смешиванием с холодным оборотным свинцом с температурой $380^{\circ} \mathrm{C}$. Исходный черновой свинец содержал 4\% меди, 1,4\% мышьяка. Одновременно в верхней зоне смешения свинца с температурой $530{ }^{\circ} \mathrm{C}$ непрерывно забираются в полость вращающегося фильтра центрифуги. Отфильтрованные сыпучие шликера содержат $36 \% \mathrm{Cu} ; 11,1 \% \mathrm{As} ; 1,9 \% \mathrm{~S}$ с выходом 10,4\%. При центробежной фильтрации на выбросе из фильтра свинец содержал 0,33\% меди, 0,21\% мышьяка. Из нижней зоны сливался отрафинированный свинец с содержанием $0,06 \%$ меди, $0,18 \%$ мышьяка, $0,06 \%$ серы. Таким образом от резкого охлаждения образуются сыпучие шликера 
без настылеобразования, которые выводятся фильтром по мере их образования [14.2]. С целью снижения потерь свинца со шликерами расплав охлаждают до $360-430^{\circ} \mathrm{C}$, подвергают центробежной фильтрации вместе с оборотными шликерами, а затем повторяют центробежную фильтрацию после вмешивания серы и вновь удаляют шликера. В последующей работе авторы [15.2] показали, что при центробежной фильтрации оптимальная температура свинца $400-450^{\circ} \mathrm{C}$.

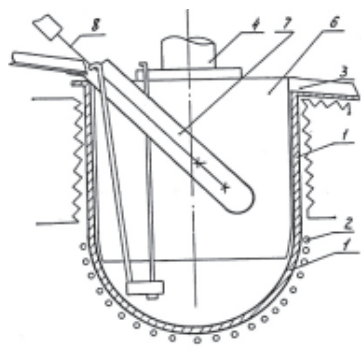

a

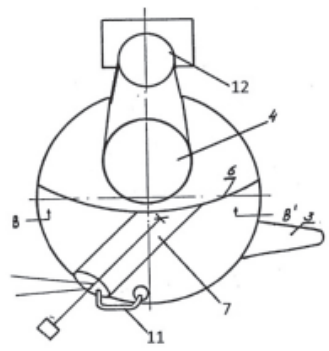

б

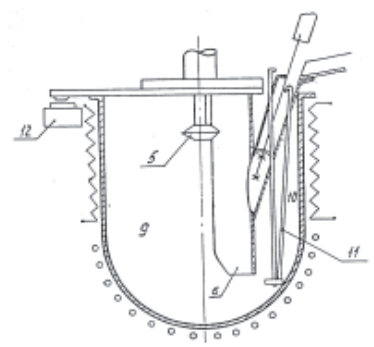

B

Рис. 2.3. Схема установки центробежной фильтрации свинца.

Узлы: 1 - котел с обогревом; 2 - холодильник; 3 -желоб слива; 4 - центрифуга;

5 - тарели фильтра; 6 - экран; 7 -лоток подачи смеси металла; 8-мешалка; 9 - зона кристаллизации; 10 - сифонная зона; 11 - насос с сифоном; 12 - бункер транспортера шликеров

При этом максимальный выход шликеров составил около 3,5\% от чернового свинца при содержании $46,2-50 \% \mathrm{~Pb} ; 26,4-28,7 \% \mathrm{Cu} ; 11,5 \%$ As. Содержание примесей в свинце после центрифугирования не превышало $0,20 \% \mathrm{Cu}$ и $0,3 \%$ As. Тем не менее, узким местом использования центробежного обезмеживания свинца является цикличность операций. Поэтому авторы периодически возвращаются к совершенствованию непрерывного рафинированию с использованием центробежной фильтрации.

\section{2. Тонкое обезмеживание}

После грубого обезмеживания дальнейшее удаление меди до 0,005\% продолжают вмешиванием элементарной серы в металл. Для достижения кондиции приходится многократно повторять операции вмешивания серы и снятием шликеров и при этом происходит значительное ее возгорание. Это значительно увеличивает выход свинца в шликера.

Тонкое обезмеживание также можно вести с помощью погружной центрифуги, используя ее как автоматическое устройство для удаления сульфидных съемов. Процесс осуществляется по обычной схеме с применением 
серы. В металл при температуре $330-380^{\circ} \mathrm{C}$ вводили элементарную серу в количестве $0,1 \%$ массы металла. Во избежание налипания сульфидов на внутренней стенке тарелей центрифуги перемешивание металла продолжали до прекращения горения серы. Результаты лабораторных испытаний центробежном рафинировании чернового свинца завода «Электроцинка» приведены в табл. 2.8.

Таблица 2.8

Результаты центробежного рафинирования на стадии тонкого обезмеживания на УКСЦК

\begin{tabular}{|c|c|c|c|c|}
\hline \multicolumn{2}{|c|}{ Содержание \%, Си в } & \multicolumn{2}{c|}{ Состав шликеров } & \multirow{2}{*}{ Выход шликеров, \% } \\
\cline { 1 - 2 } черновом & рафин. & $\mathrm{Cu}$ & $\mathrm{Pb}$ & \\
\hline 0,27 & 0,0026 & 80,5 & 8,2 & 3,42 \\
\hline 0,24 & 0,0029 & 63,5 & 7,5 & 3,38 \\
\hline 0,21 & 0,0068 & 76,5 & 10,2 & 2,18 \\
\hline 0,21 & 0,0028 & 73 & 7,5 & 3,84 \\
\hline 0,18 & 0,0028 & 69,3 & 8,1 & 2,3 \\
\hline 0,14 & 0,0045 & 91,3 & 3 & 2,67 \\
\hline 0,13 & 0,0025 & 86,5 & 4,3 & 3,48 \\
\hline сред & & & & 3,04 \\
\hline
\end{tabular}

Примечание. Температура вмешивания $-340^{\circ} \mathrm{C}$; температура фильтрации $340-350^{\circ} \mathrm{C}$.

Испытания на лабораторной установке [11.2] показали, что фильтрация при температуре $430^{\circ} \mathrm{C}$ после вмешивания оборотных сульфидных шликеров относительный выход свинца в шликера составляет $\mathrm{Pb} /(\mathrm{Cu}+\mathrm{As})=2,2-3,5$.

На второй стадии для получения содержания $0,005 \% \mathrm{Cu}$ в свинце предложено вмешивать элементарную серу при температуре $340{ }^{\circ} \mathrm{C}$ и относительный выход свинца в шликера увеличивается до $\mathrm{Pb} /(\mathrm{Cu}+\mathrm{As})=14,6$ - 42,2. Предложено [16.2] расплавленный металл после вмешивания шликеров охлаждать до $360-430^{\circ} \mathrm{C}$ и подвергать центробежной фильтрации вместе с оборотными шликерами с периодическим удалением шликеров, а затем повторяют центробежную фильтрацию после вмешивания серы, причем вначале фильтрацию ведут с вводом оборотных шликеров в количестве, обеспечивающем соотношение сульфида свинца в шликерах к содержанию мышьяка в металле, 
равном 0,02-0,18. Лабораторными исследованиями показано, что при центробежном рафинировании чернового свинца, содержащего $0,7-1,14 \% \mathrm{Cu}$, $0,49-0,74 \%$ As, выход шликеров составляет 6-7,3\% при содержании свинца в шликерах $61,8-70 \%$.

Испытания на Новосибирском оловянном комбинате центробежной фильтрации 60 т чернового свинца УКСЦК, содержащего 0,52\% Си, $0,64 \%$ As, промышленной центрифугой ПАФВС-650 также показали, что выход шликеров составляет 5,0\%, выход свинца в шликера $-3,7 \%$, с получением полупродукта с содержанием $0,018 \%$ Си и $0,39 \%$ As [13.2].

Для испытания непрерывного рафинирования может служить модернизация котла под промышленный центробежный аппарат ПАФВС-650. На практике принято мнение, что $\mathrm{Cu}_{2} \mathrm{~S}$ образуется взаимодействием меди с образовавшимся $\mathrm{PbS}$. Сера растворяется в свинце при $450^{\circ} \mathrm{C}$ до $0,6 \%$, а при дальнейшем увеличении происходит образование соединения $\mathrm{PbS}$. Термодинамические расчеты показывают, что процесс удаления меди проходит за счет реакции растворенной серы и растворенной примеси. Реакция $\mathrm{PbS}$ с растворенной примесью Си проходит в 100 раз менее интенсивно, чем с растворенной серой [13.2].

Это согласуется с мнением М.П. Смирнова [1.2]. Чтобы снизить выход свинца в съемы нужно снижать образование $\mathrm{PbS}$ и для этого предпочтительно вмешивать серу в азотной атмосфере. Это предусмотренно в котле с центрифугой [9.2] дополнительно поставлена решетка с выделением отстойной зоны, с опушенным металлопроводом слива олова, а в среднюю часть на уровне решетки опущен газопровод подачи реагентов азотом. Высота ликвационной и отстойной зоны в 2-3 раз больше высоты зоны фильтрации (рис. 2.4) Зона фильтрации ванны 1 отделена съемной решеткой 5 от цилиндрической 6 зоны, которая в свою очередь разделена съемной решетной 7 на верхнюю ликвационную зону 8 и нижнюю отстойную 9 зону [17.2]. На дно отстойной зоны 9 погружен выход металлопровода 23 для слива рафинированного свинца с помощью вакуумного сифона 24 [13.2].

Процесс непрерывного тонкого обезмеживания свинца проводился на модельной установке [17.2] с помощью центробежного аппарата ЦП-120.

В ванну 1 заливается свинец для тонкого обезмеживания. По газопроводу 25 через эжектор 26 азотом вдувают древесные опилки с элементарной серой. При этом проходят реакции взаимодействия серы с растворенной медью с образованием шликера $\mathrm{Cu}_{2} \mathrm{~S}$. По мере охлаждения расплава в ликвационной зоне 8 до температуры $330-350{ }^{\circ} \mathrm{C}$ всплывают образующиеся шликера. 


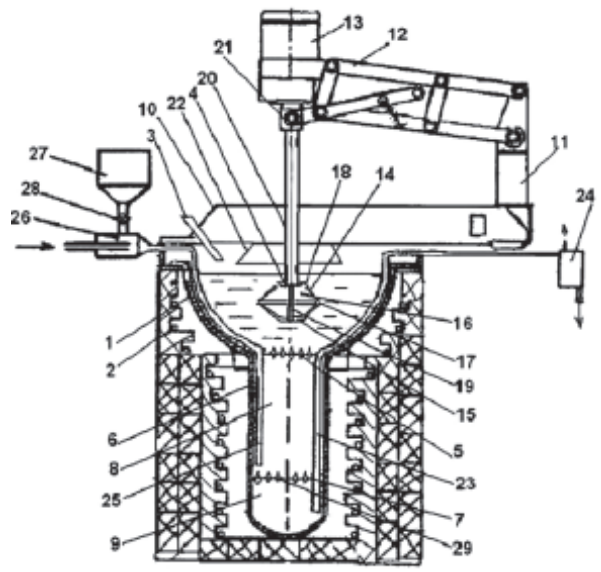

Рис. 2.4. Установка непрерывного тонкого обезмежсивания фильтрацией.

Узлы: 1 -ванна; 4-фильтр центрифуги; 5-решетка; 8-ликвационная зона; 23 - металлопровод для слива; 25 - азотопровод подачи серы

Одновременно в зоне фильтрации свинец со шликерами захватываются через окна 18 в полость 16 фильтра 4 и под действием центробежных сил продавливаются через щель 17 , а шликера остаются в полости 16 фильтра 4. Фильтр 4 приподнимается над поверхностью расплава на уровень отражателя 22 и под действием центробежных сил твердые шликера освобождаются от жидкого свинца. Фильтр приподнимается на уровень сборника 10 шликеров, отключается сжатие тарелей и под действием центробежных сил осадок шликеров выбрасывается в сборник 10. Цикл фильтрации повторяется до прекращения наполнения фильтра. В зоне 9 отстоя цилиндрической ликвационной ванны 6 , отделенной решеткой 7 металл отстаивается от выделяющихся кристаллов шликеров и свинец металлопроводом 23 сливается с помощью вакуумного сифона 24 до уровня снижения металла в ванне 1 до решетки 5. Цикл рафинирования повторяется.

Расход серы в указанном интервале мало влияет на выход меди в шликера и в среднем составляет $\mathrm{Pb} / \mathrm{Cu}=22$. Оптимизировать расход серы возможно путем разработки нерерывного цифрового контроля содержания серы в свинце. Оптимизировать производительность возможно устранением цикличности путем разработки регулирования скорости заливки и откачивания слива. В табл. 2.9 приведены результаты модельных испытаний тонкого обезмеживания свинца. 
Таблица 2.9

Результаты испытания полунепрерывного тонкого обезмеживания свинца центробежной фильтрацией

\begin{tabular}{|c|c|c|c|c|c|c|c|c|c|c|}
\hline \multirow{2}{*}{$\begin{array}{l}\text { Номер } \\
\text { плавки }\end{array}$} & \multicolumn{2}{|c|}{ Ванна Pb } & \multicolumn{2}{|c|}{ Заливка Pb } & \multirow{2}{*}{$\begin{array}{c}\text { Расход } \\
\mathrm{S}, \%\end{array}$} & \multicolumn{2}{|c|}{ Шликера } & \multicolumn{2}{|c|}{$\mathrm{Pb}$ на сливе } & \multirow{2}{*}{$\begin{array}{c}\text { Доля, \% } \\
\text { слива }\end{array}$} \\
\hline & КГ & $\mathrm{Cu}, \%$ & $\mathrm{K \Gamma}$ & $\mathrm{Cu}, \%$ & & КГ & $\mathrm{Cu}, \%$ & КГ & $\mathrm{Cu}, \%$ & \\
\hline 1 & 105 & 0,22 & 40 & 0,3 & 0,07 & 4,8 & 4,79 & 30 & 0,01 & 0,21 \\
\hline 2 & 110 & 0,108 & 60 & 0,2 & 0,029 & 5,4 & 3,97 & 60 & 0,006 & 0,35 \\
\hline 3 & 105 & 0,02 & 80 & 0,3 & 0,042 & 6,1 & 4,00 & 80 & 0,008 & 0,43 \\
\hline 4 & 99 & 0,01 & 80 & 0,3 & 0,041 & 5,5 & 4,50 & 40 & 0,012 & 0,22 \\
\hline
\end{tabular}

На заводе «Электроцинк» проведены опытно-промышленные испытания по обезмеживанию чернового свинца в электрообогреваемых котлах емкостью 23 т с использованием погружной центрифуги ПАФВС-800. Обезмеживанию подвергали черновой свинец шахтной плавки (расплавленный после загрузки в котел в виде слитков) следующего состава, \%: 1,0-1,2 Си, 0,12-0,2 B1, 0,6-0,9 As, 0,8-1,0 Sb. Температуру свинца в котлах в ходе рафинирования снижали с 420 до $370-$ $380^{\circ} \mathrm{C}$. Тарельчатый фильтр диаметром 800 мм с верхними заборными окнами погружали в расплав и вращали с частотой 200 мин $^{-1}$ в течение 30-40 с, достаточных для набора шликеров. Затем фильтр приподнимали над поверхностью расплава и на 10-30 с увеличивали скорость его вращения до 650 мин $^{-1}$ для отжима жидкого свинца [11.2]. После этого фильтр приподнимали до уровня скребкового транспортера, опоясывающего зону разгрузки, и осадок разгружали под действием центробежной силы при раскрытии тарелей. Шликеры после центробежного рафинирования представляли собой сыпучую массу, не содержащую корольков свинца. Первые порции шликеров состояли в основном из крупных зерен диаметром 1,5 мм, но по мере ведения процесса размер частиц уменьшался и к концу операции получили тонкодисперсные шликеры. Обезмеживание заканчивали после снятия всех шликеров.

Промышленные испытания чернового свинца от шахтной плавки состава $1-1,2 \% \mathrm{Cu} ; 0,6-0,9 \% \mathrm{As} ; 0,8-1 \% \mathrm{Sb}$ на заводе «Электроцинк» проводился на котле емкостью 23 т. Скорость вращения фильтра диаметром 80 см на заполнении 200 об/мин в течение 30-40 с, а на отжатие жидкого свинца из твердых шликеров составляла 650 об/мин. Продолжительность операции отделения шликеров 1-1,17 час и за это время получалось 1,85-2,95 т шликеров [11.2]. Как видно из данных табл. 2.12, применение центробежного рафинирования позволило снизить на $3 \%$ 
содержание свинца в шликерах - 17-20\%, и увеличить на 4-5\% содержание меди по сравнению с обычными заводскими шликерами. Продолжительность операции отделения шликеров с использованием центрифуги составила $1-1,17$ ч, за это время получено сухих шликеров 1,85-1,95 т. Результаты опытов центробежного рафинирования свинца приведены в табл. 2.10.

Табли ца 2.10

Результаты промышленных испытаний грубого обезмеживания чернового свинца завода «Электроцинк»

\begin{tabular}{|c|c|c|c|c|c|c|c|c|c|c|}
\hline \multicolumn{2}{|c|}{$\begin{array}{c}\text { Исходный } \\
\text { свинец }\end{array}$} & \multicolumn{2}{|c|}{$\begin{array}{c}\mathrm{Pb} \text { рафиниро- } \\
\text { ванный }\end{array}$} & \multicolumn{3}{|c|}{$\begin{array}{c}\text { Состав } \\
\text { шликеров, \% }\end{array}$} & \multirow{2}{*}{$\mathrm{Cu} / \mathrm{As}$ is $\mathrm{X}$} & \multicolumn{2}{|c|}{ Степ удален } & \multirow{2}{*}{$\begin{array}{c}\text { Потери } \\
\mathrm{Pb} / \mathrm{CuAs}\end{array}$} \\
\hline $\mathrm{Cu}$ & As & $\mathrm{Cu}, \%$ & As, $\%$ & $\mathrm{~Pb}$ & $\mathrm{Cu}$ & As & & $\mathrm{Cu}, \%$ & As, $\%$ & \\
\hline 1,74 & 1,96 & 0,02 & 1,2 & 63,3 & 26,3 & 10,2 & 0,89 & 98,9 & 44,0 & 1,7 \\
\hline 1,56 & 2 & 0,057 & 1,2 & 65,6 & 24,6 & 9,6 & 0,78 & 96,7 & 45,8 & 1,9 \\
\hline 1,5 & 1,3 & 0,077 & 0,32 & 76,8 & 16,8 & 6,2 & 1,15 & 95,3 & 77,5 & 3,3 \\
\hline 1,46 & 1,41 & 0,082 & 0,98 & 77,3 & 17,3 & 6,1 & 1,04 & 94,9 & 36,4 & 3,3 \\
\hline 1,4 & 1,2 & 0,08 & 0,5 & 77,2 & 15,6 & 6,3 & 1,17 & 94,8 & 61,9 & 3,5 \\
\hline 1,34 & 1,25 & 0,064 & 0,8 & 78 & 15,5 & 6,1 & 1,07 & 95,6 & 41,4 & 3,6 \\
\hline 1,3 & 1 & 0,071 & 0,45 & 78 & 15,4 & 6,2 & 1,30 & 95,0 & 59,0 & 3,6 \\
\hline 1,27 & 1,1 & 0,076 & 0,48 & 80,6 & 14,2 & 5,2 & 1,15 & 94,5 & 60,0 & 4,2 \\
\hline
\end{tabular}

Процесс центрифугирования осложняется образованием крупных кусков шпейзы на поверхности при застывании слитков свинца [11.2]. Особенностью обезмеживания свинца заключается в высоком содержании меди и мышьяка, которые отфильтровываются в виде шликеров способных образовывать настыли. Это вызывает необходимость искать изменение приемов центробежной фильтрации.

$\mathrm{C}$ увеличением соотношения (Cu/As) до 1,5 в исходном черновом олове выход As в шликера увеличивается:

$\mathrm{IzAs}=34,6 \cdot(\mathrm{Cu} / \mathrm{As})_{\text {atis }}+18,9$ при $(\mathrm{Cu} / \mathrm{As})_{\text {atis }}<2,1$ с корреляцией $0,76$.

Затем с превышением соотношения более 1,5 выход As в шликера снижается:

$$
\mathrm{Iz}_{\mathrm{As}}=91,9-1,2 \cdot(\mathrm{Cu} / \mathrm{As})_{\mathrm{atis}} \text { при }(\mathrm{Cu} / \mathrm{As})_{\text {atis }}>2 \text { с корреляцией } 0,73 \text {, }
$$

где $\mathrm{Iz}_{\mathrm{As}}$ - извлечение в шликера; $(\mathrm{Cu} / \mathrm{As})_{\text {atis }}$ - соотношение атомных концентраций в исходном свинце. 
Сопоставление полученных результатов| концентрирования меди в шликерах с показателями, приведенными в литературе, показывает, что средний выход свинца на единицу удаляемой меди несколько ниже при центробежной фильтрации. На свинцовом заводе «Ковогута» (г. Пшибрам, Чехия) в качестве лицензионной рекламы проведены испытания промышленного аппарата ПАФВС-650 центробежной фильтрации шликеров чернового свинца и дроссов тонкого сульфидного обезмеживания.

Для испытания рафинирования предложен черновой свинец двух сортов: от плавки аккумуляторного лома в шахтной печи состава в \%: 95-96 Pb; 0,3-0,7 Cu; 0,009-0,04 Ag; 2,5-3,5 Sb; 0,1 Sn; 0,1 As; 0,016 Bi [15.2], с низким содержанием серебра; и серебросодержащий черновой свинец от рудной плавки вместе с серебросодержащим ломом состава, \%: 92-95 Рb; 0,5-0,7 Cu; 0,1-0,15 As; 3,5-4,5 Sb; 0,5-1 Sn; 0,2 As; 0,012 Bi. Испытания проводились на 90-тонных котлах диаметром 2,4 м. Центрифугу ПАФВС-650 (рис. 2.9 и 2.10), (описанную в работе [10.1] устанавливали на специально изготовленную крышку.

Блоки чернового свинца загружали в котел и по мере подплавления подгружали до заполнения объема котла, после чего устанавливали импеллерную мешалку для размешивания металла. Температура металла при фильтрации периодически снижалась от $550^{\circ} \mathrm{C}$ и заканчивалась фильтрация при $340^{\circ} \mathrm{C}$ во время сульфидной обработки. При фильтрации периодически отбирали пробы свинца и шликеров для анализа [15.2]. В табл. 2.11 приведены результаты производственных испытаний обезмеживания чернового свинца. Всего во время испытаний отрафинировано 1116 т.

Таблица 2.11

Основные результаты производственных испытаний обезмеживания чернового свинца центробежной фильтрацией

\begin{tabular}{|c|c|c|c|c|c|c|c|c|}
\hline \multirow{2}{*}{$\begin{array}{l}\text { Номер } \\
\text { плавки }\end{array}$} & \multirow{2}{*}{$\begin{array}{c}\text { Масcа, } \\
\text { тонн }\end{array}$} & \multirow{2}{*}{$T,{ }^{\circ} \mathrm{C}$} & \multicolumn{2}{|c|}{$\begin{array}{c}\text { Содержание } \\
\text { меди, \% }\end{array}$} & \multicolumn{2}{|c|}{$\begin{array}{c}\text { Состав шли- } \\
\text { керов, \% }\end{array}$} & \multirow{2}{*}{$\begin{array}{c}\text { Извлече- } \\
\text { ние } \mathrm{Cu} \\
\text { в шликер }\end{array}$} & \multirow{2}{*}{$\begin{array}{c}\text { Выход } \mathrm{Pb}, \% \text {, } \\
\text { в шликера }\end{array}$} \\
\hline & & & исход. & конеч. & $\mathrm{Pb}$ & $\mathrm{Cu}$ & & \\
\hline 280 & 89 & $430-400$ & 0,75 & 0,19 & 68,6 & 8,27 & 74,7 & 5,1 \\
\hline 283 & 92,4 & 400 & 0,71 & 0,181 & 69,9 & 9,1 & 75,7 & 4,3 \\
\hline 288 & 75 & 400 & 0,68 & 0,21 & 53,4 & 21,5 & 69,7 & 1,2 \\
\hline 289 & 80 & 430 & 0,56 & 83 & 68,2 & 12,6 & 77 & 2,7 \\
\hline 291 & 100 & $400-380$ & 0,997 & 0,1 & 54,1 & 15,2 & 90 & 3,4 \\
\hline 279 & 79 & 430 & 0,21 & 0,13 & 82,4 & 4,5 & 40,2 & 1,6 \\
\hline 281 & 88 & 430 & 0,31 & 0,095 & 66,1 & 10,4 & 70 & 1,4 \\
\hline 282 & 80 & 400 & 0,76 & 0,08 & 74,5 & 7,9 & 63,6 & 4,8 \\
\hline сред & & & 0,62 & 0,134 & 67,1 & 11,2 & 70,4 & 3,06 \\
\hline
\end{tabular}


Таблица 2.12

Показатели производственных испытаний тонкого обезмеживания фильтрацией

\begin{tabular}{|c|c|c|c|c|c|c|c|c|}
\hline \multirow[t]{2}{*}{$\begin{array}{l}\text { Номер } \\
\text { плавки }\end{array}$} & \multirow[t]{2}{*}{$T,{ }^{\circ} \mathrm{C}$} & \multirow{2}{*}{$\begin{array}{c}\text { Исходное } \\
\text { содержа- } \\
\text { ние, } \%, \mathrm{Cu}\end{array}$} & \multicolumn{2}{|c|}{ Содержание Сu, \% } & \multirow{2}{*}{$\begin{array}{c}\text { Выход, } \\
\%, \text { шли- } \\
\text { керов }\end{array}$} & \multicolumn{2}{|c|}{$\begin{array}{c}\text { Состав } \\
\text { шликеров, } \\
\%\end{array}$} & \multirow{2}{*}{$\begin{array}{c}\text { Выход, } \\
\%, \text { Рb } \\
\text { в шли- } \\
\text { кера }\end{array}$} \\
\hline & & & исходн. & рафинир. & & $\mathrm{Pb}$ & $\mathrm{Cu}$ & \\
\hline 280 & $350-340$ & 0,144 & 0,19 & 0,001 & 2,32 & 79,4 & 7,61 & 1,94 \\
\hline 283 & 340 & 0,094 & 0,18 & 0,001 & 2,5 & 81,5 & 6,9 & 2,1 \\
\hline 288 & 340 & 0,924 & 0,21 & 0,008 & 1,7 & 74,6 & 12 & 1,3 \\
\hline 289 & 340 & 0,151 & 0,083 & 0,003 & 1,9 & 83,4 & 4,6 & 1,6 \\
\hline 282 & $380-340$ & 0,012 & 0,08 & 0,001 & 2,87 & 72,8 & 9,4 & 2,16 \\
\hline Сред. & & & 0,149 & & 2,26 & 78,3 & 8,1 & 1,82 \\
\hline
\end{tabular}

Примечание. Фильтрация при тонком обезмеживании плавок 280, 282 осуществлялась не при фиксированной температуре, а фильтрация с одновременным снижением температуры, начиная с 380 до $340^{\circ} \mathrm{C}$.

Среднее содержание меди в отрафинированном полупродукте после центробежной фильтрации шликеров грубого обезмеживания составляет $0,134 \%$ при содержании в шликерах $67,1 \% \mathrm{~Pb}, 11,2 \%$ Си. Средний выход шликеров грубого обезмеживания - 4,37\%. Самый высокий выход шликеров составил $6,94 \%$, в то время как по существующей технологии среднемесячный выход шликеров $-13,4 \%$.

\section{3. Центробежная фияьтрация в щелочном рафинировании свинца}

Рафинирование свинца от мышьяка, олова, сурьмы выполняют обработкой щелочью с селитрой с высоким расходом реагентов. При щелочном рафинировании свинца окислением примесей селитрой образуются олово-сурьмянистые плавы. На удаление суммы мышьяка и олова расход щелочи составляет 3,5 кг на кг удаленной примеси, а на удаление сурьмы расход составляет 2,1 кг/кг [1.2]. Причем, расходуется только $30 \%$ для окисления металлической примеси в химические соединения типа $\mathrm{Na}_{2} \mathrm{SnO}_{3}$ отделяемой от свинца в виде щелочного плава. Олово и сурьма в щелочном расплаве находится в виде нерастворимых соединений $\mathrm{Na}_{2} \mathrm{SnO}_{3}$ и $\mathrm{Na}_{3} \mathrm{SbO}_{4}$, в виде суспензии мелкодисперсных частиц размером 20 мкм. Обычно на практике процесс рафинирования ведут до накопления в расплаве 15-20\% соединений олова и сурьмы. После этого плав, 
содержащий 45-60\% щелочи, выводят на гидрометаллургическую переработку. Гидрометаллургическая переработка щелочных плавов - это много операционный трудо затратный процесс. Известен способ рафинирования сурьмы от примесей в присутствии щелочного шлака [18.2]. Способ заключается в том, что после окисления сурьмы в присутствии щелочного шлака и отделения его от металла, окисление ведут в присутствии кислого шлака с добавлением извести, окиси или сульфата трехвалентного железа. Съемы снимаются центробежной фильтрацией.

Известен аппарат совмещающий взаимодействие расплава металла с флюсом в центрифуге [19.2]. В аппарате нагрев фильтра с отходами ведут при одновременной промывке их жидким флюсом. В качестве флюса используют глицерин или глицерин с добавкой 1-10\% хлористого аммония и процесс ведут при температуре $160-210^{\circ} \mathrm{C}$. Устройство включает фильтр в виде двух конусообразных тарелей, соединенных большими основаниями, в котором верхняя тарель выполнена в виде усеченного конуса. С целью повышения регенерации щелочи из плава рафинирования свинца от олова, сурьмы проведены опыты по регенерции щелочи из щелочных плавов центробежной фильтрацией погружаемым фильтром [20.2]. Для этого в расплав вмешивают реагент, например, гашеная известь, хлористый кальций, сульфат кальция, гидроокись железа, граншлак, содержащий окислы кальция, железа. Лабораторные опыты проводились на центрифуге (рис. 2.5), со съемным контейнерным фильтром применяемой в переработке индиевых отходов [21.2]. Фильтр (рис. 2.6) в виде двух разно наклонных конических тарелей, обращенных друг к другу большими основаниями диаметром 110 мм с образованием зазора для отделения жидкого расплава. В опытах использованы плавы полученные при рафинировании свинца от мышьяка и от олова с сурьмой. Навески 200 г плавов с добавками реагентов загружались в полость фильтра, который погружался в ванну для нагрева до $550^{\circ} \mathrm{C}$.

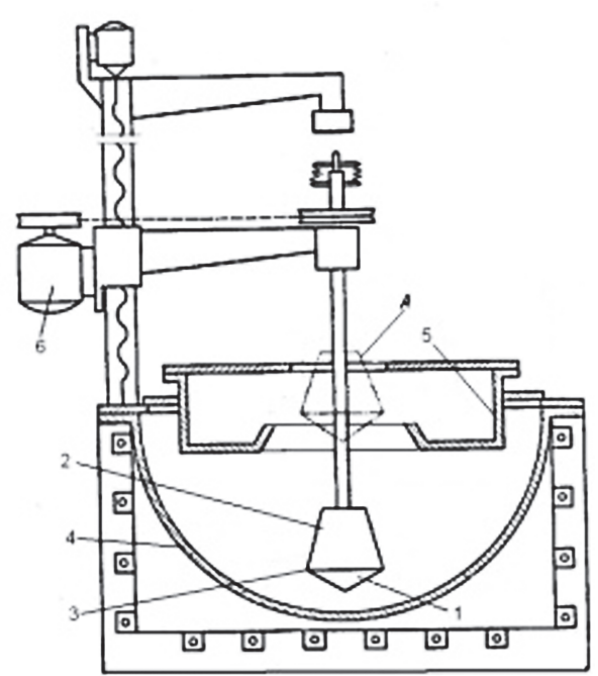

Рис. 2.5. Центрифуга с контейнерным фильтром 


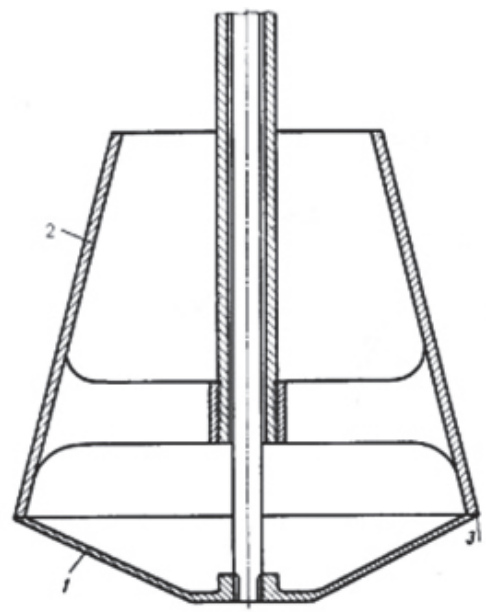

Рис. 2.6. Фильтр в виде контейнера для загрузки плава:

1 - нижняя тарель; 2 - верхний конус; 3 - фильтрующая щель;

4 - ванна с обогревом;

5 - сборник жидкого расплава;

6 - двигатель постояного тока

для привода вращения фильтра

Контроль температуры нагрева тарелей погруженных в ванну осуществлялся хромель алюмелевой термопарой с прибором TPM-1. После выдержки в течение 1 часа фильтр приподнимался в положение «А» для охлаждения до температуры $420^{\circ} \mathrm{C}$ и включалось вращение фильтра со скоростью 900 об/мин на 3 мин. При этом расплав щелочи выбрасывается в приемник, а осадок остается в фильтре. В навеску 200 г солевого плава с исходным содержанием $3,2 \% \mathrm{Sn}$ и $5,6 \% \mathrm{Sb}$ добавляется навеска хлористого кальция, загружается в фильтр контейнер и нагревается с расплавлением до температуры $550^{\circ} \mathrm{C}$. Через 60 мин перемешивания периодическим включением вращения 200 об/мин фильтр-контейнер приподнимается до уровня «А» для охлаждения. По достижении температуры $420^{\circ} \mathrm{C}$ фильтр приводят во вращения до 900 об/мин. При этом расплав щелочи выбрасывается в приемник, а осадок остается в фильтре (табл. 2.13).

Та блица 2.13

Результаты очистки щелочных плавов фильтрацией от олова и сурьмы

\begin{tabular}{|c|c|c|c|c|c|c|c|c|}
\hline \multirow{2}{*}{$\begin{array}{l}\text { Номер } \\
\text { опыта }\end{array}$} & \multirow{2}{*}{$\begin{array}{l}\mathrm{Bec}, \mathrm{\Gamma} \text {, } \\
\mathrm{CaCl}_{2}\end{array}$} & \multirow{2}{*}{$\begin{array}{c}\text { Расход, г/Г, } \\
(\mathrm{Sn}+\mathrm{Sb})\end{array}$} & \multicolumn{2}{|c|}{ Фильтр осадок } & \multicolumn{2}{|c|}{ Плав $\mathrm{NaOH}$} & \multirow{2}{*}{$\begin{array}{l}\text { Выход, } \\
\%, \mathrm{NaOH}\end{array}$} & \multirow{2}{*}{$\begin{array}{l}\text { Степень, } \\
\% \text {, очист- } \\
\text { ки } \mathrm{NaOH}\end{array}$} \\
\hline & & & $\mathrm{Sn}, \%$ & $\mathrm{Sb}, \%$ & $\mathrm{Sn}, \%$ & $\mathrm{Sb}, \%$ & & \\
\hline 1 & 0 & 0,0 & 16,5 & 34,6 & 2,9 & 5,0 & 86,1 & 11,3 \\
\hline 2 & 0 & 0,0 & 9,0 & 18,3 & 2,7 & 4,5 & 72,3 & 33,2 \\
\hline 3 & 11 & 0,7 & 19,0 & 34,2 & 1,1 & 1,9 & 88,9 & 69,7 \\
\hline 4 & 15 & 0,9 & 19,0 & 34,1 & 1,0 & 1,6 & 89,4 & 74,1 \\
\hline 5 & 18 & 1,1 & 17,4 & 35,8 & 0,8 & 1,3 & 88,8 & 84,7 \\
\hline 6 & 21 & 1,3 & 18,9 & 34,1 & 0,7 & 1,1 & 90,5 & 80,6 \\
\hline 7 & 26 & 1,6 & 18,9 & 34,0 & 0,6 & 1,0 & 91,3 & 82,7 \\
\hline
\end{tabular}


В табл. 2.13 приведены результаты опытов по центробежной фильтрации плавов.

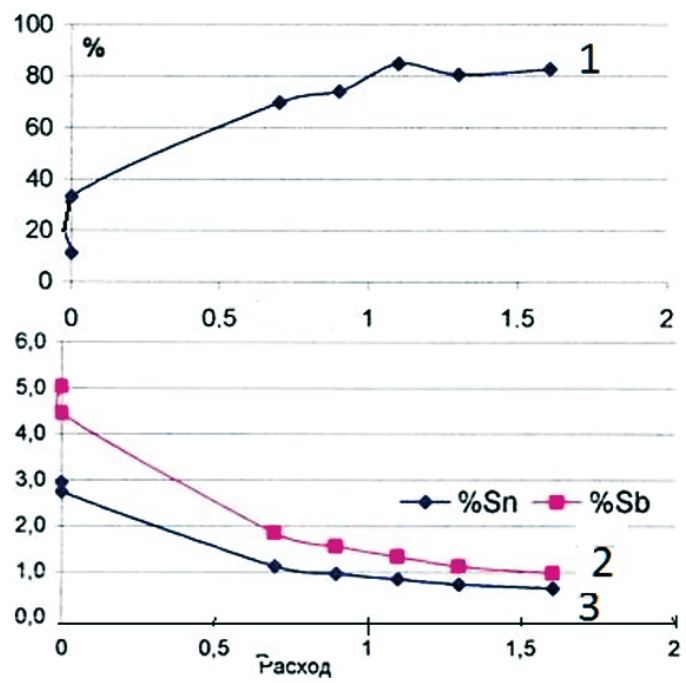

Рис. 2.7. Влияние расхода хлористого кальция на степень очистки плава от примесей. 1 - степень очистки плава от олова, сурьмы;

2 - содержание \% сурьмы в очищенной щелочи; 3 - содержание \% олова в очищенной щелочи. По абсциссе - расход $\mathrm{CaCl}_{2}$ на кг примесей $(\mathrm{Sn}+\mathrm{Sb})$

Результаты на рис. 2.7 показывают, что при оптимальном расходе $0,9-$ $1,3 \mathrm{kг} \mathrm{CaCl}_{2}$ на кг примесей $(\mathrm{Sn}+\mathrm{Sb})$ достигается $80 \%$ степень очистки расплава щелочи. Содержание олова и сурьмы в плаве в этих условиях $2 \%$. Регенерированная щелочь становится пригодной для повторного использования в процессе рафинирования. Результаты можно объяснить коагуляцией образующихся нерастворимых соединений по реакциям:

$$
\begin{gathered}
1 \mathrm{Na}_{2} \mathrm{SnO}_{3}+\mathrm{CaCl}_{2}=\mathrm{CaSnO}_{3}+2 \mathrm{NaCl} ; \\
2 \mathrm{Na}_{3} \mathrm{SbO}_{4}+3 \mathrm{CaCl}_{2}=\mathrm{Ca}_{3}\left(\mathrm{SbO}_{4}\right)_{2}+6 \mathrm{NaCl} .
\end{gathered}
$$

Мышьяк в щелочном плаве после рафинирования свинца находится в виде соединения $\mathrm{Na}_{3} \mathrm{AsO}_{4}$ с высокой растворимостью $25 \%$ [1.2]. В навеску 200 г щелочного плава с содержанием 9,9\% мышьяка добавляется навеска реагента $\mathrm{Fe}(\mathrm{OH})_{3}$ и загружается в фильтр контейнер и затем нагревается с расплавлением до температуры $550^{\circ} \mathrm{C}$. Через 60 мин перемешивания периодическим включением вращения 200 об/мин фильт-контейнер 
приподнимается до уровня «А» для охлаждения. По достижении температуры $420^{\circ} \mathrm{C}$ фильтр приводят во вращение до 900 об/мин. При этом расплав щелочи выбрасывается в приемник, а осадок остается в фильтре. В табл. 2.14 приведены показатели центробежной фильтрации щелочного плава от мышьяка.

Табли ца 2.14

Результаты очистки щелочных плавов от мышьяка

\begin{tabular}{|c|c|c|c|c|c|c|}
\hline \multirow{2}{*}{$\begin{array}{l}\text { Номер } \\
\text { опыта }\end{array}$} & \multirow{2}{*}{$\begin{array}{c}\mathrm{Bec}, \Gamma, \\
\mathrm{Fe}(\mathrm{OH})_{3}\end{array}$} & \multirow{2}{*}{$\begin{array}{c}\mathrm{Fe}(\mathrm{OH})_{3}, \\
\text { Кг } / \mathrm{Кг} \mathrm{As}\end{array}$} & \multicolumn{2}{|c|}{ Содержание As, \% } & \multirow{2}{*}{$\begin{array}{c}\text { Выход, \%, } \\
\mathrm{NaOH}\end{array}$} & \multirow{2}{*}{$\begin{array}{c}\text { Степень, } \\
\%, \text { очистки } \\
\mathrm{NaOH}\end{array}$} \\
\hline & & & осадок & расплав & & \\
\hline 8 & 20 & 0,8 & 27,2 & 3,88 & 83,2 & 63 \\
\hline 9 & 25 & 1,0 & 27,2 & 2,8 & 85 & 74 \\
\hline 10 & 28 & 1,1 & 26,1 & 2,2 & 85 & 80 \\
\hline 11 & 33 & 1,3 & 24,1 & 1,7 & 84,7 & 85 \\
\hline
\end{tabular}

На рис. 2.8 показано что с увеличением расхода до 1,3 кг $\mathrm{Fe}(\mathrm{OH})_{3}$ на кг мышьяка степень очистки щелочного плава от мышьяка увеличивается до $85 \%$, а в очищенной щелочи содержание мышьяка остается 1,7\%.

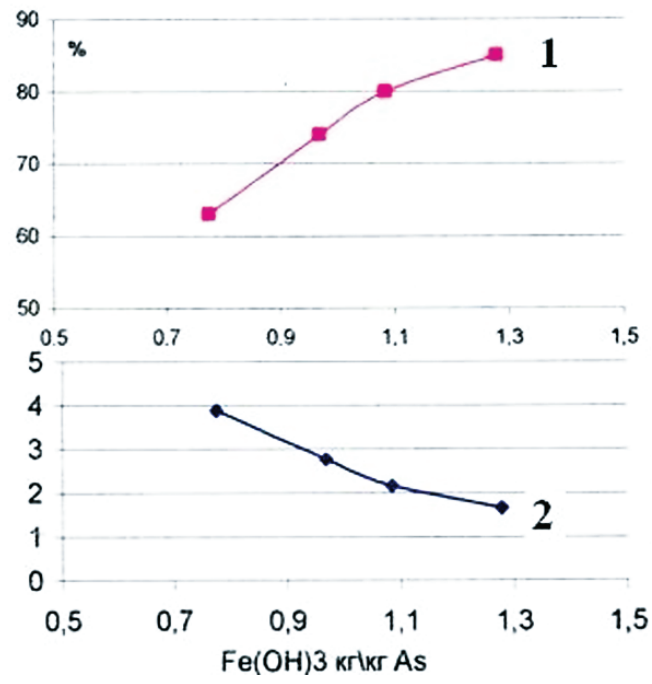

Рис. 2.8. Влияние расхода $\mathrm{Fe}(\mathrm{OH})_{3}$

на показатели центробежной фильтрации плава от мышьяка:

1 - степень \% очистки плава от мышьяка; 2 - содержание мышьяка в очищенной щелочи 
Показатели можно объяснить образованием нерастворимого соединения мышьяка в щелочном плаве по реакции:

$$
\mathrm{Na}_{3} \mathrm{AsO}_{4}+\mathrm{Fe}(\mathrm{OH})_{3}=\mathrm{FeAsO}_{4}+3 \mathrm{NaOH} .
$$

Отфильтрованный от основной доли мышьяка щелочной плав предназначен для повторного использования в процессе рафинирования свинца. Кроме того, выделение мышьяка в селективный осадок позволяет снизить расходы на захоронение вредных отходов. Опыты показали, что обработка щелочных плавов при $550^{\circ} \mathrm{C}$ с оптимальным расходом $1,1 \mathrm{\kappa г} \mathrm{CaCl}_{2}$ на кг примесей $(\mathrm{Sn}+\mathrm{Sb})$ позволяет центробежной фильтрацией достигнуть очистки расплава щелочи до содержания $0,8 \%$ олова и $1,3 \%$ сурьмы в плаве. Обработка щелочных плавов с расходом 1,3 кг $\mathrm{Fe}(\mathrm{OH})_{3}$ на кг мышьяка позволяет центробежной фильтрацией достигнуть очистки щелочного до содержания $1,7 \%$. мышьяка. Очищенная щелочь предназначена для повторного использования в процессе рафинирования. Однако, стабильность результатов очистки по всей вероятности зависит длительности и температуры кристаллизации, а также от дисперсности фаз добавляемых реагентов.

Технология регенерации щелочи из плавов использована непосредственно в процессе щелочного рафинирования свинца от мышьяка, олова и сурьмы с помощью измененного центробежного аппарата [22.2]. Особенностью центробежного щелочного рафинирования является вмешивание в щелочной рафинирующий расплав реагента-осадителя связывающий примеси в соль, малорастворимую в расплавленной щелочи. Перемешивание осуществляют забором расплавленного свинца и диспергированием его в слой щелочного расплава. После стадии перемешивания осуществляют забор щелочного расплава над поверхностью свинца и уплотнением твердого осадка путем отстаивания в центробежном поле. Для связывания мышьяка в качестве реагента вмешивают гидрат окиси железа, сульфат железа. Для связывания олова, сурьмы в качестве реагента вмешивается хлористый кальций или известь.

Укрупненные опыты проведены на центрифуге (рис. 2.9), используемой для припоев, с двигателем постоянного тока для вращения фильтра диаметром 200 мм с заменой оснастки фильтра [22.2].

Свинец нагревается до температуры расплава $500-550^{\circ} \mathrm{C}$. В ванну камеры 16 загружаются реагенты из расчета на содержание примесей и расплавляются. Механизмом 15 устанавливается зазор 2-3 мм щели 7 между тарелями. В расплав свинца погружается ротор 4 с фильтром 5,6 на глубину погружения заборного окна 11 в расплав свинца. Фильтр приводится во вращение на 400 об/мин. За счет центробежных сил и лопаток 12 расплав свинца через окно 11 всасывается в полость фильтра и выбрасывается через фильтрующую щель 7 в камеру 16 с расплавом реагентов и у стенки цилиндра 16 камеры стекает по зазору между стенками 16,18 в расплав котла, обеспечивая циркуляцию свинца (показано стрелками на рис. 2.10). 


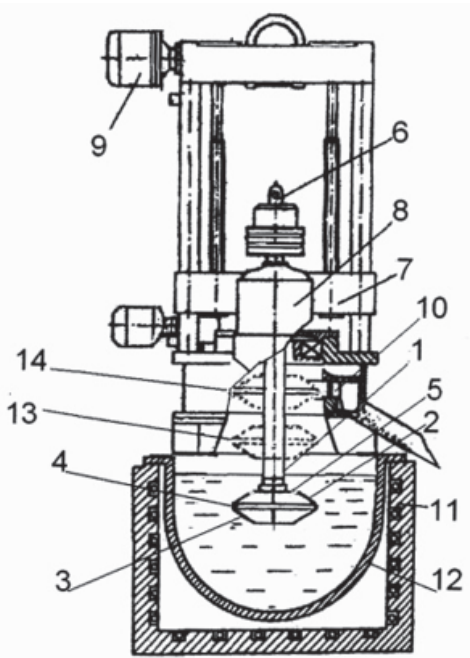

a

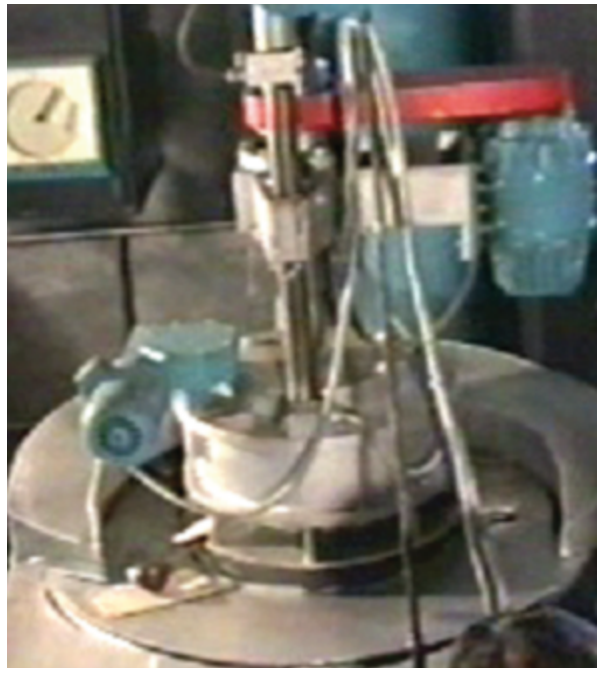

б

Рис. 2.9. Центрифуга ЦП-200:

б - фото центрифуги ЦП-200 из фильма демонстрации японской делегации

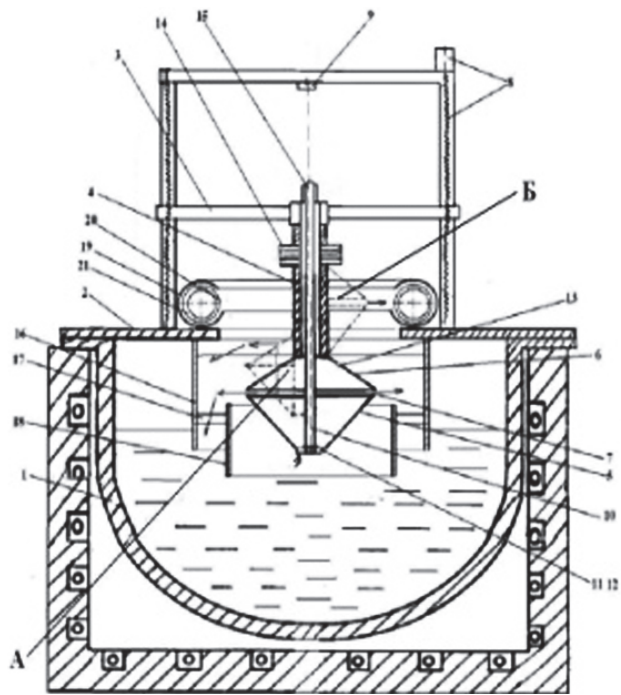

Рис. 2.10. Центробежный аппарат для щелочного рафинирования свиниа от примесей. Основные узлы: 12 -лопасти; 13 - окно сброса; 16 - цилиндр камеры; 17 - крестовина; 18 - ограничительный цилиндр 
По завершении заданной длительности стадии перемешивания ротор 4 с фильтром 5, 6 (рис. 2.11) [22.2] механизмом 8 приподнимают на уровень основания вершины конуса верхней тарели 6 ниже станины 2, соответствующий положению заборного окна 11, 12, выше поверхности расплава свинца (показано пунктиром положение «А»). В этом положении фильтрующая щель 7 плотно сжата до зазора 0,1 мм.

Фильтр приводится во вращение со скоростью 1100 об/мин. Заборное окно 11, 12 захватывают суспензию щелочного плава в полость фильтра 5 , 6, и по его наполнении происходит расслаивание плава на твердые тяжелые фракции солей примесей у щели и более легкий жидкий щелочной плав ближе к центру с выбрасыванием через окна сброса 13 в объем плава (обозначено пунктиром и стрелкой на рис. 2.11). Через заданный проме-

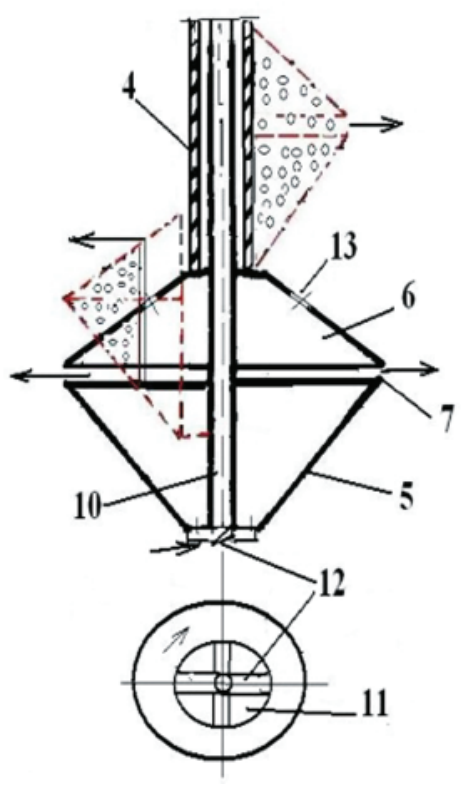

Рис. 2.11. Фильтр.

Основные узль: 7 - фильтрующая щель; 11 - заборное окно жуток времени механизмом 8 фильтр приподнимают на уровень фильтрующей щели 7 напротив щелевидного зазора 20, (показано пунктиром положение «Б»). Заборное окно 11 нижней тарели 5 в этом положении располагается над уровнем солевого плава в камере 16. В этом положении механизмом 9 (рис. 2.10) тарели 5, 6 раскрываются и осадок примесей выбрасывается через щель 7 в кольцевой сборник 19 и выводятся спиральным 21 конвейером. Цикл повторяется до прекращения выделения осадка твердых примесей. Операции загрузки окислителя, реагента - осадителя повторяют добавкой их в регенерированный объем щелочи до получения необходимой чистоты свинца по каждой примеси. Результаты опытов приведены в табл. 2.15. Результаты приведенные в табл. 2.15 показывают, что операции очистки свинца вмешиванием реагентов предпочтительно проводить при $T=520^{\circ} \mathrm{C}$, а фильтрацию при $350^{\circ} \mathrm{C}$. Для повышения выхода очищенной оборотной щелочи в расплав добавлять часть реагента с зернистой структурой, типа $\mathrm{Fe}_{2}(\mathrm{SO} 4)_{3}$ и $\mathrm{CaCl}_{2}$. Отрафинированный свинец в среднем содержал $0,007 \%$ As; $0,006 \%$ Sn; 0,007\% Sb. Лучшие результаты очистки $0,005 \% \mathrm{As} ; 0,0025 \mathrm{Sn} ; 0,005 \% \mathrm{Sb}$ получены в опытах 1, 4 . 
Результаты испытания щелочного рафинирования центробежной фильтрацией

\begin{tabular}{|c|c|c|c|c|c|c|c|c|c|c|c|c|}
\hline \multirow{2}{*}{$T,{ }^{\circ} \mathrm{C}$} & \multicolumn{4}{|c|}{ Расход реагентов, г } & \multirow{2}{*}{$\begin{array}{c}\text { Вес, } \\
\text { кг, } \\
\text { осад. }\end{array}$} & \multicolumn{3}{|c|}{$\begin{array}{c}\text { Плав. } \\
\text { п/с фильт. }\end{array}$} & \multicolumn{3}{|c|}{ Состав осадка } & \multirow{2}{*}{$\begin{array}{l}\text { Про- } \\
\text { цент } \\
\text { реген. } \\
\mathrm{NaOH}\end{array}$} \\
\hline & $\mathrm{Fe}(\mathrm{OH})_{3}$ & $\mathrm{Fe}_{2}\left(\mathrm{SO}_{4}\right)_{3}$ & $\mathrm{Ca}(\mathrm{OH})_{2}$ & $\mathrm{CaCl}_{2}$ & & $\begin{array}{c}\text { As, } \\
\%\end{array}$ & $\begin{array}{l}\mathrm{Sn}, \\
\%\end{array}$ & $\begin{array}{c}\mathrm{Sb}, \\
\%\end{array}$ & $\begin{array}{c}\text { As, } \\
\%\end{array}$ & $\begin{array}{l}\mathrm{Sn}, \\
\%\end{array}$ & $\begin{array}{c}\mathrm{Sb}, \\
\%\end{array}$ & \\
\hline 350 & 427 & 160 & 551 & 165 & 2,88 & 2,7 & 3,8 & 3,2 & 24,1 & 10,6 & 29,6 & 68,7 \\
\hline 420 & 512 & 160 & 551 & 165 & 2,71 & 2,4 & 3,4 & 2,8 & 25,8 & 11,3 & 31,6 & 77,9 \\
\hline 520 & 427 & 160 & 551 & 165 & 2,53 & 1,7 & 0,8 & 1,9 & 28,6 & 15,0 & 34,8 & 81,3 \\
\hline 420 & 342 & 160 & 147 & 112 & 2,57 & 4,4 & 4,4 & 5,2 & 26,5 & 12,0 & 32,2 & 60,7 \\
\hline 420 & 512 & 0 & 168 & 0 & 2,68 & 3,4 & 4,9 & 5,8 & 26,1 & 11,5 & 30,9 & 53,9 \\
\hline 520 & 512 & 0 & 168 & 0 & 3,02 & 4,4 & 2,2 & 5,2 & 22,9 & 11,8 & 28,2 & 41,9 \\
\hline $350 / 520$ & 342 & 160 & 441 & 112 & 2,34 & 1,7 & 0,9 & 2,0 & 30,8 & 16,1 & 37,6 & 79,1 \\
\hline
\end{tabular}

Постоянные условия: навеска 150 кг состава 0,2\% As; 0,15\% Sn; 0,3\% Sb; расход щелочи 2,83 кг; расход селитры 0,7 кг; котел емкостью 14 л, диаметр фильтра 20 см, скорость вращения фильтра при заборе 400 об/мин, при отстое - 1100 об/мин.

Сыпучий осадок в опытах 1,2 содержал от 1 до $17 \% \mathrm{~Pb} ; \mathrm{NaOH}-12-$ $15 \%$. Средняя степень очистки металла от примесей 96-98\%. Результаты показывают, что расход щелочи снижается на 80-89\%, а осадки примесей получаются практически без металлического свинца, что снижает расходы на их переработку. Кроме того, способ снижает затраты на захоронение опасных мышьяковистых отходов. В достижении стабильности результатов очистки плава от примесей перспективно отладить отстойный режима путем замены фильтра в центрифуге на специальный отстойно фильтрующий фильтр (рис. 2.12) [23.2]. Такой фильтр снабжен дополнительными конусами 12 размещенными внутри тарелей и закрепленных с зазором 11.

Под действием центробежных сил жидкий плав всасыванием в полость и заполняет скапливаются у щели осадком в фильтрующем режиме выбрасыванием жидкой щелочи через щель 9. Затем после забивания щели протекает отстойный режим. Под действием центробежных сил плав расслаивается тяжелый твердый осадок накапливается в полости а жидкая более легкая жидкогфаза выдавливается через щель 15 (между конусами 12, 14) и выбрасывается через выводные каналы 16.

После заполнения в полости между тарелями 7-8 и конусами $12-14$ твердым осадком фильтр приподнимают над расплавом, раскрывают тарели фильтра уровень сборника для выброса осадка под действием центробежных сил. 


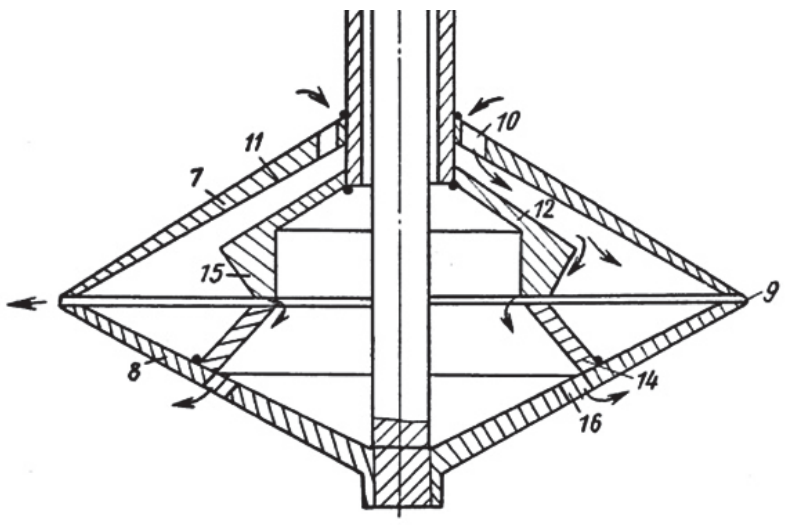

Рис. 2.12. Фильтр отстойно-фильтрующий.

Основные узлы: 9 - фильтрующая щель наружная; 15 - внутренняя фильтрующая щель; 16 - выводные каналы выброса

Подобный щелочной плав от осадка разделяли авторы работы [24.2], в которой фильтр в виде сжатых тарелей (рис. 2.13) или барабана (рис. 2.13, б) диаметром 60 мм вращали в расплаве щелочной суспензии со скоростью 300-900 об/мин. В режиме сушки над расплавом вращали со скоростью 1200 об/мин.

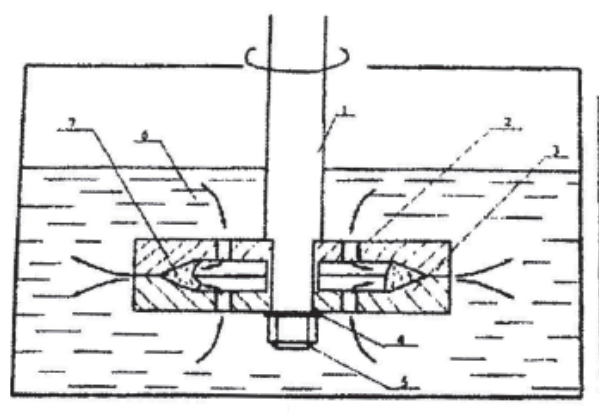

a

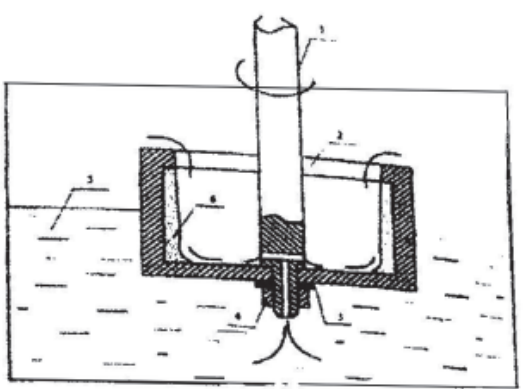

6

Рис. 2.13. Отстойный фильтрующий фильтр [24.2].

Основные узлы: 2 - заборные окна; 3 - фильтрующая щель;

6, 7 - полость накопления осадка

Определили, что активное накапливание осадка в фильтре диаметром 60 мм начинается при скорости вращения 700-800 об/мин. 


\section{4. Центробежная фильтрация в обессеребрении свинца}

В практике рафинирования свинца от серебра в расплав металла при температуре $510-530^{\circ} \mathrm{C}$ вмешивают оборотную серебристую пену и после охлаждения до $460-480^{\circ} \mathrm{C}$ снимают богатую пену с выходом до $1,5 \%$ и содержанием 5-8\% Ag; 22-35\% Zn. Затем в свинец вмешивают цинк из расчета для образования соединений $\mathrm{AgZn}_{3}$ и после охлаждения до $340^{\circ} \mathrm{C}$ снимают бедную оборотную пену с выходом $10 \%$ [2.2].

На свинцовом заводе «Ковогута» (г. Пшибрам, Чехия) проведены рекламные испытания промышленного аппарата ПАФВС-650 [15.2] на котлах емкостью 90 т диаметром 2,4 м по обезмеживанию и обессеребрению чернового свинца. Существующая на заводе схема обессеребрения включает операции удаления серебристых оборотных продуктов вручную шумовкой при ступенчатом снижении температуры. В среднем за месяц выход товарной серебристой пены 3,4\%, которая содержит, \%: $5,54 \mathrm{Ag}$; $52 \mathrm{~Pb} ; 32 \mathrm{Zn}$. Затем вручную с выходом 4,6\% снимается богатая серебристая пена и бедная серебристая пена с выходом 9,3\%. Поэтому, проведены испытания центробежного аппарата для выявления возможности снижения выхода оборотов и обогащения богатой серебристой пенки.

После обезмеживания и щелочного рафинирования от мышьяка, олова и сурьмы в свинец с массой 71,1 т и содержанием $0,21 \%$ Ag добавляли 14 т серебристой пены от предыдущих операций. При температуре $480^{\circ} \mathrm{C}$ за 120 мин центробежной фильтрацией снято 1,8 т богатых сыпучих шликеров с содержанием, \%: 14,48 Ag; $50 \mathrm{~Pb} ; 34 \mathrm{Zn}$, т.е. со степенью концентрирования 2,6 раза. Операцию с получением свинца с содержанием $0,0003 \%$ Ag. закончили по существующей схеме. Испытания показали принципиальную возможность сбора богатых серебристых шликеров центробежной фильтрацией с повышением степени концентрирования серебра в шликерах в 2,6 раза [15.2].

\section{5. Центробежная фильтрация в обезвисмучивании свинца}

После обезмеживания, щелочного рафинирования и обессеребрения свинец нагревают до $370-380^{\circ} \mathrm{C}$ и растворяют в нем металлический кальций и магний для образования соединений $\mathrm{Ca}_{3} \mathrm{Bi}_{2}, \mathrm{CaMg}_{2} \mathrm{Bi}_{2}$. По мере охлаждения до $360-350^{\circ} \mathrm{C}$ снимают крановой шумовкой первичные дроссы с выходом 3-4\% от массы ванны, которые содержат 3-5\%Ви. Металл продолжают охлаждать вплоть до затвердевания и непрерывно снимают бедные дроссы до содержания висмута 0,01-0,007\%. Выход всех дроссов обезвисмучивания 12-14\% от массы свинца [1.2]. При удалении висмута из свинца по существующей технологии в висмутистые 
дроссы переходит значительное количество свинца, что обусловливает необходимость многократной переработки дроссов для получения висмутистого свинца. Происходит ликвация интерметаллических соединений $\mathrm{CaMg}_{2} \mathrm{Bi}_{2}$ и $\mathrm{Ca}_{3} \mathrm{Bi}_{2}$, в результате дроссы обогащаются до $8-12 \% \mathrm{Bi}$. Затем их расплавляют в другом котле, где при $450-550{ }^{\circ} \mathrm{C}$ удаляют кальций, магний и цинк каустической содой. Для извлечения висмута из полученного висмутистого свинца его подвергают электролитическому разделения в водном кремнефтористом электролите с выводом висмута в виде шлама [2.2].

Трудоемкость переработки бедной висмутистой пены всегда вынуждало к поискам технологии отделения жидкой металлической пены с поверхности металла центробежной фильтрацией. Горное бюро (США) использовало центрифугу Bergsoe для исследования обезвисмучивания свинца [25.2]. Центрифуга Bergsoe (рис. 1.4) с фильтром - корзиной погружаемой в расплав более подробно описана в работе Muller и Pascher [26.2]. Центрифуга с фильтром-корзиной диаметром 0,53 метра, вращающимся со скоростью 210-650 оборотов в минуту. Ротор перфорирован отверстиями 2,0-2,6 мм и покрыт стекловолокном. Во время испытаний ротор конусообразной частью погружали при температуре $350^{\circ} \mathrm{C}$ в верхний слой расплавленного металла. В свинец, содержащий $0,5 \%$ висмута, предварительно вмешивали кальций, магний в необходимых количествах. Под действием вращающихся лопастей расплав поднимался вверх через отверстия в дне конуса. Жидкий металл выбрасывался наружу через отверстия, а твердые кристаллы оставались на стенке ротора. Затем частоту вращения ротора увеличивали от 575 до 900 об/мин для удаления остатков жидкого металла. Отфильтрованный продукт содержал $0,03 \%$ висмута. При этом извлечение висмута в висмутистые дроссы выше $90 \%$ [27.2]. Поиск способов применения центробежной фильтрации в обезвисмучивании свинца в основном сводился к получению съемов, богатых по висмуту. Однако, процесс обесвисмучивания, также как и обессеребрения можно рассматривать с двух точек зрения.

Во-первых, это удаления висмута как примеси вредной для свинца. В среднем на разных заводах черновой свинец содержит $0,05-0,4 \%$ висмута. Растворение магния и кальция в расплавленном свинце приводит к связыванию висмута в тугоплавкие тонкодисперсные соединения $\mathrm{Ca}_{3} \mathrm{Bi}_{2}\left(1350^{\circ} \mathrm{C}\right), \mathrm{Mg}_{3} \mathrm{Bi}_{2}\left(823^{\circ} \mathrm{C}\right), \mathrm{Bi}_{2} \mathrm{CaMg}_{2}$, которые со кристаллизуются с такими же соединениями избыточных реагентов со свинцом $\mathrm{Ca}_{2} \mathrm{~Pb}$ $\left(1100^{\circ} \mathrm{C}\right), \mathrm{Mg}_{2} \mathrm{~Pb}\left(550^{\circ} \mathrm{C}\right)$, которые в свою очередь легко смачиваются жидким свинцом с образованием пены. Центробежная фильтрация не позволяет отделить из пены тонко дисперсные соединения висмута. 
Однако, в этом варианте могут быть применимы отстойно фильтрующие фильтры. При фильтрации тонко дисперсных расплавов неоднократно уделялось внимание изменению конструкции отстойного фильтра для обеспечения уплотнения и кристаллизации суспензии. Для этого одна из тарелей снабжена кольцеобразной крышкой (рис. 1.35) [28.2].

Фильтр погружается в расплав нижним конусом чтобы захватывать нижними окнами пену с поверхности расплава. Скорость вращения фильтра в таком погруженном состоянии выше чем обычно 500-800 об/мин для одновременного расслаивания пены в полости. Длительность цикла вращения фильтра в режиме забора значительно увеличена до 15-30 мин, чем обычно. Под действием центробежных сил жидкий свинец с повышенной плотностью, прижимается к периферии отстойной полости 17 , а более легкая пена магний-висмутовых соединений накапливаются в отстойной полости 17 ближе к центру. При расслаивании пены жидкий свинец выдавливается по каналу сифона, образованному стенкой тарели 10 и конусной перегородкой 18 и через отверстие 19 выбрасывается (показано стрелкой) в котел. По мере накопления в кольцевой отстойной полости 17 твердые соединения пены выдавливаются (показано стрелкой) через край кольцеобразной крышки 16 в зазор между тарелью 9 и крышкой 16 для фильтрации.

Жидкий свинец из пены продавливается под действием центробежных сил через фильтрующую щель 11 (показано стрелкой) в котел. Твердые соединения накапливаются в зазоре между крышкой 16 и тарелью 9 и с повышением их концентрации кристаллизуются в кристаллы. Периодически по мере накопления осадка фильтр приподнимается над уровнем расплава до уровня разгрузки осадка и тарели 9 и 10 фильтра разжимаются и осадок под действием центробежных сил выбрасывается в зону разгрузки. В дополнении к опытам со съемным фильтром к лабораторной центрифуге потребуется серия исследований влияния числа оборотов и длительности обработки.

Промышленные экземпляры центрифуги ПАФВС-650 использовали для испытаний для экономически более значимых операций - выделение шликеров с более высокой концентрации примеси и минимальным содержанием свинца. Для расширения области применения центрифуги ПАФВС-650 на заводе «Электроцинк» проверены испытания центрифуги с погружаемым фильтром для удаления висмута из свинца [11.2]. При исходном содержании $1,32 \%$ висмута в черновом свинце с оборотами при расходе магния 1,8 г/кг свинца и кальция 0,7 г/кг свинца в отфильтрованных дроссах содержание висмута составило 8,66\%. Для сравнения при снятии висмутовой пены содержание висмута в дроссах составляло 
$3,48 \%$. При обогащении полученной висмутистой пены со средним содержанием 5,66\% путем центробежной фильтрации при $400^{\circ} \mathrm{C}$ при добавке только одного реагента магния получены дроссы с содержанием висмута $18,2-20,9 \%$.

Более масштабно проведены испытания центрифуги ПАФВС-650 на Чимкентском свинцовом заводе по обогащению первичных висмутистых дроссов на котле емкостью 50 т [29.2]. Показано, что дроссы, снятые центрифугой при температурах $360-370^{\circ} \mathrm{C}$ содержат $10-15 \% \mathrm{Bi}$. Центрифугирование дроссов позволяет в 2-3 раза повысить содержание в них висмута [29.2]. Это значительно облегчает дальнейшую их переработку на висмутистый свинец.

На свинцовом заводе Дальполиметалл проведено испытание центрифуги ПАФВС-650 на обогащении висмутовых дроссов центробежной фильтрацией. В черновом свинце содержание висмута $0,4 \%$. Для удаления висмута до содержания $0,1 \%$ при температуре $370^{\circ} \mathrm{C}$ обычно вмешивают реагенты с расходом Сa $-1,04$ кг/т и $\mathrm{Mg}-1,68$ кг/т. Снимают богатые дроссы с содержанием 3-6\% Ви и накопления их. В последующем снижают температуру до $340^{\circ} \mathrm{C}$ для снятия бедных оборотных дроссов. Богатые дроссы переплавкой обогащают до $12 \%$ Ви. После щелочной обработки получают висмутистый свинец.

Для переработки висмутистого свинца на заводе Дальполиметалл нашло применение электролизное разделение свинца и висмута в расплаве солей [30.2]. Способ заключается в том, что процесс ведут в двухслойном электролите: верхний слой содержит хлорид свинца до $2 \%$, хлорид цинка 30-40\%, хлорид натрия 15-25\%, остальное хлористый калий; а нижний слой: хлорид свинца $-50-65 \%$, хорид цинка $-10-20 \%$, хлорид натрия $-5-10 \%$, остальное хлорид калия. Способ осуществляется в электрообогреваемом котле диаметром 930 мм, высотой 800 мм из стали Х12Н9Т. Котел служит катодом и снабжен сифонным сливом свинца. В качестве анодной ванны служит кварцевая ванна диаметром 675 мм. Температура электролиза $420-450^{\circ} \mathrm{C}$. Производительность электролизера 180 кг/сутки. Электролизное разделение сплава свинца и висмута в расплаве солей более экономично работает при загрузке в анод сплава с содержанием висмута более $20 \%$. Целью испытаний центрифуги являлось определение условий обогащения висмутовых шликеров до содержаний $20 \%$ висмута. Центрифугой ПАФВС-650 на котле 130 т центробежной фильтрацией чернового свинца с содержанием $1 \%$ Ви получены дроссы $12,1-14,8 \%$ Ви с выходом $4,5 \%$. В табл. 2.16 приведены отдельные плавки фильтрации богатых дроссов при $450{ }^{\circ} \mathrm{C}$ с получением висмутистого свинца. 
Таблица 2.16

Результаты испытания обогащения шликеров фильтрацией

\begin{tabular}{|c|c|c|}
\hline \multicolumn{3}{|c|}{ Содержание висмута, \% } \\
\hline Исходный $\mathrm{Pb}$ & Конечный $\mathrm{Pb}$ & Ві в дроссах \\
\hline 4,5 & 0,58 & 18,8 \\
\hline 7 & 0,53 & 36,4 \\
\hline 7,1 & 0,16 & 35 \\
\hline
\end{tabular}

Отмечено что при переплавке богатых висмутистых дроссов происходит их окисление и даже возгорание. При этом окисляется и свинец покрывающий кристаллы соединений. Это ведет к повышению выхода дроссов, снижению содержания висмута и нестабильности по содержанию висмутистого свинца.

Для предотвращения возгорания висмутистых шликеров предложено в свинце растворять магний без кальция при более низкой температуре в сплаве с цинком [31.2]. Способ извлечения висмута из висмутистого свинца заключается в том, что магний задают в расплав в виде лигатуры с цинком и образовавшиеся дроссы окисляют. Отделение дроссов производят центробежный фильтрацией, а окисление вмешиванием сульфата аммония или сульфата цинка при более низкой температуре $340-360^{\circ} \mathrm{C}$.

Таблица 2.17

Результаты опытов обогащение висмутовых шликеров центробежной фильтрацией

\begin{tabular}{|c|c|c|c|c|c|c|c|c|}
\hline \multirow{2}{*}{$\begin{array}{c}\text { Номер } \\
\text { опыта }\end{array}$} & \multicolumn{4}{|c|}{ Исход металл } & \multicolumn{4}{c|}{ Дроссы } \\
\cline { 2 - 9 } & вес, кг & $\mathrm{Bi}, \%$ & $\mathrm{Mg}, \%$ & $\mathrm{Zn}, \%$ & $\mathrm{zec}, \mathrm{кг}$ & $\mathrm{Bi}, \%$ & $\mathrm{Mg}, \%$ & $\mathrm{Zn}, \%$ \\
\hline 1 & 3,2 & 6,09 & 3,13 & 3,13 & 0,75 & 21,5 & 3,7 & 0,3 \\
\hline 2 & 3,2 & 6,09 & 3,13 & 3,13 & 0,62 & 27,1 & 4,7 & 0,4 \\
\hline 3 & 3,2 & 6,09 & 3,13 & 3,13 & 0,7 & 25 & 4,4 & 0,3 \\
\hline 4 & 3,2 & 6,09 & 3,13 & 3,13 & 0,5 & 36,2 & 6,3 & 0,5 \\
\hline 5 & 3,18 & 6,14 & 4,41 & 1,89 & 0,53 & 34,9 & 6,1 & 0,6 \\
\hline 6 & 3,18 & 6,14 & 4,41 & 1,89 & 0,55 & 29,8 & 5,2 & 0,6 \\
\hline
\end{tabular}

Получаемые обогащенные висмутовые дроссы пригодны для перерабатки электролизом в расплаве на электролизерах [32.2]. Электролизер (рис. 2.14) содержит футерованную обогреваемую катодную ванну с помещенной в нее анодной емкостью из диэлектрика с изолированным 
графитовым токопроводом. В электролизере анодная емкость установлена на подставку высотой, равной 0,8-1,2 высоты анодной емкости, а катодная ванна снабжена карманом с сифонной перегородкой и сливным отверстием на высоте 0,6-1,0 высоты подставки.

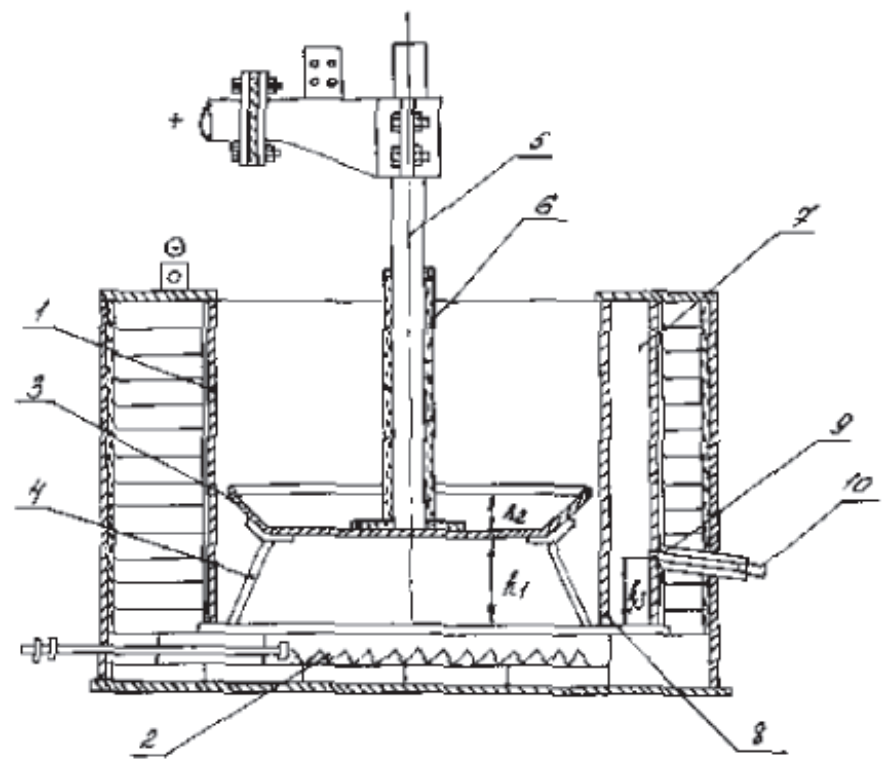

Рис. 2.14. Электролизер разделения свинца от висмута.

Основные узлы: 1 - корпус - катод - нержавстальной;

3 - чаща квариевая для анодного висмута; 10 - сифон свинца

Опыт эксплуатации электролизеров описан в работе [33.2], где обобщены результаты освоения переработки свинцово - висмутовых сплавов электролизом в расплаве хлоридов цинка, калия и натрия. Приведены результаты одного цикла переработки сплава электролизом в расплаве. Выявлены особенности образования шламов и их снижение путем вмешивания хлорида аммония. Показана возможность сконцентрировать висмут на аноде с удалением свинца, олова, а на катоде получить свинцово-оловянный сплав с минимальным содержанием висмута, пригодным для припоев.

В последствии на основе опыта эксплуатации для снижения шламообразования электролизер (рис. 2.15) усовершенствован [34.2], и включает футерованную обогреваемую катодную ванну с помещенной в нее 
анодной чаши с изолированным графитовым токоподводом, в котором графитовый токоподвод выполнен полым и снабжен штуцером с каналом подачи воздуха и эжекционной подачи порошка хлористого аммония в расплав на дно анодной емкости.

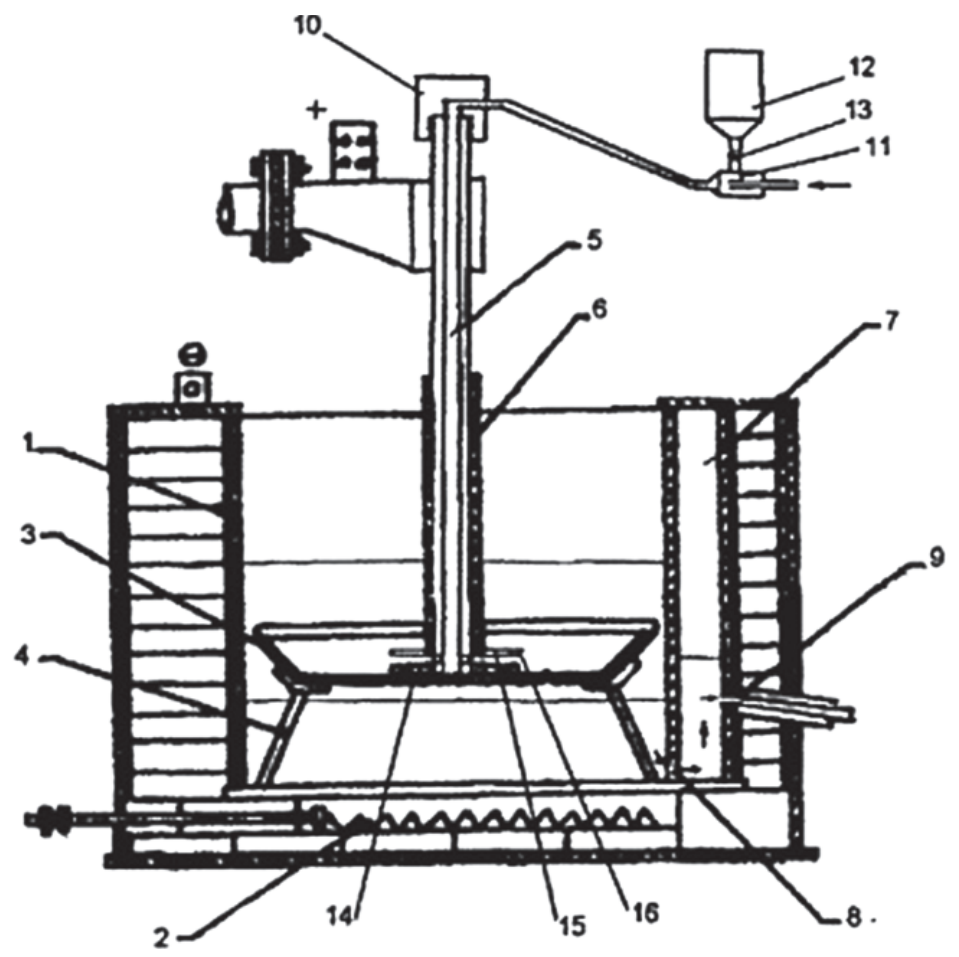

Рис. 2.15. Электролизер разделения свинца от висмута с продувкой.

Основные узлы: 1 - корпус-катод-нержавстальной;

3 - чаща кварцевая для анодного висмута; 5 - полый катод; 9 - сифон свинца; 11 - эжекционная подача хлористого аммония

Процесс ведут с продувкой исходного сплава воздухом и периодическим вмешиванием хлористого аммония в электролит эжекционной подачей.

Для очистки получаемого висмута используется обработка расплава серой и щелочью [35.2]. Способ заключается в том, что после плавления и вмешивания серы расплавленный сплав перед отделением дроссов обрабатывают сначала хлористым свинцом, а затем смесью едкого натрия с $10-17 \%$ соды. 


\section{6. Работы института Гидроцветмет и УКСЦК по исподьзованию центробежных аппаратов в процессах рафинирования свинца}

В течение 1978-1987 гг. институтом Гидроцветмет совместно с УК СЦК проводились исследования, включая лабораторные, укрупнённые опыты, опытно-промышленные и промышленные испытания по применению центробежных аппаратов в процессах рафинирования чернового свинца, на операциях грубого и тонкого обезмеживания и обессеребрения. Исследования по обезмеживанию были начаты с лабораторных опытов по изучению распределения примесей меди, мышьяка, сурьмы и других элементов по продуктам центрифугирования расплава чернового свинца, определений температурных режимов центрифугирования и составов образующихся шликеров. Опыты проводили на черновом свинце УК СЦК с различными содержаниями примесей, с использованием лабораторной погружной центрифуги с диаметром тарелей 120 мм. После нагрева расплава свинца до $600-650^{\circ} \mathrm{C}$ проводили изучение влияния температуры расплава на результаты центрифугирования в интервале температур $600-330^{\circ} \mathrm{C}$ с отбором проб через $50^{\circ} \mathrm{C}$ при равномерном охлаждении расплава. Исходный свинец содержал, \% мас.: 84,0-94,1 Pb; 0,49-6,65 Cu; 0,51-2,80 As; 1,81-1,87 Sb. При фильтрации расплава в интервале $550-330^{\circ} \mathrm{C}$ в шликеры удаляется медь и в значительной степени мышьяк. Сурьма, висмут, теллур, серебро и золото практически полностью остаются в свинцовом расплаве. Состав свинца после ценрифугирования, мас. \%: 96,5-96,8 $\mathrm{Pb} ; 0,17-0,03 \mathrm{Cu}$; 0,47-0,12 As; 1,7-1,75 Sb.

Выход шликеров составлял 4-5\% от массы исходного свинца. Шликеры, полученные при температуре более $500^{\circ} \mathrm{C}$, содержали наибольшее количество 29-40\% меди и 13-16\% мышьяка. Содержание в них свинца составляло $\sim 40-50 \%$. При низких температурах $\left(320-400{ }^{\circ} \mathrm{C}\right)$ шликеры содержали 19-20\% Cu, 10-11\% As, а содержание свинца возрастало до $65 \%$. Средневзвешенный выход шликеров, полученных в исследуемом интервале температур, составлял $7,3-7,8 \%$ от исходного расплава. Шликера содержали, мас. \%: 51-46 Pb; 26-28 Cu; 12-13 As; 1,78-3,0 Sb. Исходный свинец содержал некоторое количество сульфидов свинца и цинка, которые при ликвации переходили в шликеры вместе с арсенидами меди. Практически они являлись основными составляющими шликеров, отобранных при $650-600^{\circ} \mathrm{C}$. Наличие в шликерах некоторого количества сульфидов цинка и свинца повышает их температуру первичной кристаллизации до $\sim 1000^{\circ} \mathrm{C}$. Арсенидные соединения меди (арсениды меди, сложные арсено-сульфидные медно-свинцовые эвтектики) 
в зависимости от содержания их в шликерах кристаллизуются в области 900-560 ${ }^{\circ} \mathrm{C}$. В интервале $550-530^{\circ} \mathrm{C}$ происходит кристаллизация халькозин-галенитовой эвтектики. Имеющийся в шликерах металлический свинец является основой для образования сложных эвтектик с сульфидами свинца, меди и арсенидами меди. Кристаллизация в шликерах заканчивается затвердеванием этих сложных эвтектик на основе свинца в интервале $300-260^{\circ} \mathrm{C}$. Основу шликеров, снятых при повышенных температурах, составляют арсенидно-медные фазы и фаза на основе механически захваченного металлического свинца, а при пониженных - сульфид свинца и эвтектика на основе свинца. При высокотемпературном (600-650 $\left.{ }^{\circ} \mathrm{C}\right)$ центрифугировании расплава свинца отмечались явления прилипания шликеров к тарелям и признаки спекания всей массы шликеров в тарелях при отжиме (сушке) и выгрузке материала. Это обусловлено выделением из свинца сульфидно-арсенидной жидкой фазы с последующей её кристаллизацией во время охлаждения материала при отжиме и выгрузке. При низкотемпературном ведении процесса при температуре менее $550^{\circ} \mathrm{C}$ сульфиды свинца и меди из расплава свинца выделяются полностью в виде твёрдых фаз и прилипания к тарелям не происходит.

\section{Опытно-промышленные испытания центрифуги ПАФВС-650 на стадии грубого обезмеживания свинца}

Серия балансовых опытов, проведенная в данных условиях, показала, что при обезмеживании свинца, содержащего от 0,5 до 6,6\% $\mathrm{Cu}$, использование центробежной фильтрации даёт следующие результаты: содержание меди в шликерах достигает 25-37\%; свинца - 36,2-66,5\% (в зависимости от температуры); выход шликеров составляет 5-8\%; с содержанием меди в шликерах 25-37\%. Результаты показали, что мышьяк совместно с медью удаляется из свинца в медистые шликера на 50-90\% в зависимости от соотношения $\mathrm{Cu} / \mathrm{As}$ в виде соединения $\mathrm{AsCu}_{3}$ [36.2].

На основании полученных результатов было показано, что центрифугирование возможно использовать при грубом обезмеживании чернового свинца в режиме: охлаждение расплава (с одновременным перемешиванием) до $\sim 500^{\circ} \mathrm{C}$; последующее центрифугирование при охлаждении в интервале температур $~ 500-350^{\circ} \mathrm{C}$ до полного отделения шликеров. Использование центрифуги типа ПАФВС при грубом (ликвационном) обезмеживании чернового свинца позволяет в 2 раза сократить выход шликеров, снизить в них содержание свинца и увеличить содержание меди и мышьяка [36.2; 37.2]. 
С целью отработки режимов обезмеживания чернового свинца, полученных с использованием лабораторной центрифуги, в цехе рафинации Свинцового завода УК СЦК была смонтирована опытно-промышленная установка, включающая 2 электрообогреваемых рафинировочных котла ёмкостью по 30 т свинца и центрифугу ПАФВС-650. В период испытаний, проводимых совместно институтом Гидроцветмет и УК СЦК, было переработано 2 тыс. т чернового свинца, содержащего, \% мас.: 0,352,50 Cu 0,60-1,90 As; 1/10-1,74 Sb; 0,05-0,19 Sn. Начальная температура поступающего в котлы свинца, находилась в пределах $550-800{ }^{\circ} \mathrm{C}$.

Результаты испытаний показали, что содержание меди, мышьяка и других примесей в свинце после съёма шликеров центрифугированием остаётся на том же уровне, что и при съёме шликеров крановой шумовкой. Шликеры центрифугирования содержат $24,4 \% \mathrm{Cu}, 9,8 \%$ As и от 50 до $71,4 \% \mathrm{~Pb}$ в зависимости от состава и температуры расплава свинца при центрифугировании. Как и при лабораторных опытах, шликеры центрифугирования представляли сыпучий материал.

В период испытания был снят материальный баланс. Распределение металлов по продуктам рафинирования характеризуются следующими показателями: в шликеры переходят $3,5 \% \mathrm{~Pb} ; 90,9 \% \mathrm{Cu} ; 56,5 \% \mathrm{As}$; $7,1 \% \mathrm{Sb} ; 37,3 \% \mathrm{Sn}$. Рабочее время центрифугирования, необходимое для снятия шликеров с 30-тонного котла составило 45 мин.

Сравнением операции центрифугирования с существующим съёмом шликеров шумовкой (параллельные опыты) было установлено, что применение центрифуги снижает переход свинца в шликеры на 1,5\%. Выход шликеров уменьшается почти в 2 раза. При этом содержание свинца в шликерах ниже $(62,2 \%)$, чем в шликерах, снятых крановой шумовкой $(86,3 \%)$ [38.2]. При ведении испытаний в экстремальных температурных режимах отмечались случаи образования настыли на внутренней полости тарелей. Причиной этому является формирование при высоких температурах более $500^{\circ} \mathrm{C}$ в свинцовом расплаве жидкой галенит-халькозиновой эвтектики, а при более низких температурах - образование капель свинца с тонкодисперсными выделениями шликерных фаз. Последнее приводило также к высокому содержанию металлического свинца в шликерах (до $70 \%$ от его общего количества в шликерах). Для устранения этого явления расплав в период центрифугирования интенсивно перемешивали и принудительно охлаждали. При всех положительных результатах центрифуга ПАФВС-650, рассчитанная на работу по очистке от примесей олова на котлах ёмкостью 30 т (по свинцу) не могла быть использована на УК СЦК, где процессы рафинирования осуществляются в котлах ёмкостью 310 т по свинцу. К тому же необходимо отметить 
высокотемпературные режимы процессов. На основании успешных промышленных испытаний на стадии обезмеживания чернового свинца центрифуги ПАФВС-650 Руководством Комбината была поставлена задача создания промышленной центрифуги, необходимой производительности и надёжности работы, отвечающей требованиям технологического процесса (работа на рафинировочных котлах ёмкостью 310 т, при увеличении времени работы в условиях возросших нагрузок, повышенных температур и др. специфических особенностях условий свинцового производства).

В соответствии с поставленной задачей по х/договору с институтом Гидроцветмет с СКБ ГИТ СО АН СССР были спроектированы и изготовлены (по ходу испытаний) две центрифуги - ПАФВС-1200-1у и ПАФВС-1200-2у. По сути, новые образцы аппаратов были полными конструкторскими копиями модели центрифуги ПАФВС-650 и отличались лишь увеличенным габаритом, дающим возможность работы на 310-тонном котле, и диаметром тарелей (1200 мм), а также, в связи с этим, некоторым усилением рабочих узлов. Также образец ПАФВС1200-2у вместо цепного транспортёра для выгрузки шликеров был оборудован бункером-накопителем.

Авторы показали, что в отдельных испытаниях применение центрифуги ПАФВС-1200-2у позволяет снизить содержание свинца в шликерах в 1,4 раза и в 1,8 раза уменьшается выход шликеров и при $400-430^{\circ} \mathrm{C}$ получать свинец с содержанием меди 0,03-0,1\% [39.2]. Однако, длительные промышленные испытания на стадии обезмеживания чернового свинца данных моделей центрифуг, проведенных Институтом Гидроцветмет в производственном цикле Рафинировочного цеха УК СЦК, показали их неработоспособность. Как правило, после одного-двух операций происходили остановки, выход из строя отдельных деталей, узлов. Это приводило к нарушению технологического цикла, длительным ремонтным работам, замены дефицитных частей и деталей.

\section{Тонкое обезмеживание}

Центрифугирующая фильтрация может быть также применена на операции тонкого обезмеживания после предварительного вмешивания в расплав серы. Тонкое обезмеживание свинцового расплава с использованием центрифугирования проводили в соответствии с принятой технологией, т.е. при температуре расплава $330-340^{\circ} \mathrm{C}$ и работающей мешалке вводили серу в количестве 1,2 кг/т свинца. Образующиеся сульфидные шликеры снимали центрифугой. Результаты опытов показали, что выход шликеров составил в среднем 3,5\% [40.2]. Содержание меди в свинце после окончания операции составило 0,008-0,002\%, а в шликерах - 
от $10,1 \%$ при высоком содержании её в исходном расплаве $(0,33 \%)$ и до $2,52-0,75 \%$ при исходном содержании в расплаве $0,11-0,032 \%$. В сульфидные шликеры мышьяк переходит незначительно. Это согласуется с мнением, что сера в присутствии меди химически не влияет на вывод мышьяка из свинцового расплава. Основу сульфидных шликеров составляют сульфид свинца и фаза на основе металлического свинца.

\section{Обессеребрение свинца с исподьзованием центробежной фильтрациии}

Обессеребрение свинца на всех свинцовых заводах осуществляют путём введения металлического цинка в свинцовый расплав, предварительно очищенный от меди, мышьяка, олова и сурьмы. Процесс ведётся в две стадии с получением богатой и бедной серебристой пены. Бедная серебристая пена является оборотной. Снятие пены с поверхности свинцовой ванны производят с помощью крановой шумовки. Богатая пена содержит кусковой материал и значительное количество механически увлечённого свинца. Для дальнейших операций богатую пену подвергают грохочению с отделением крупнокускового материала, который возвращают в рафинировочный котёл. Однако в богатой пене, поступающей в купеляционное отделение, остаются высокие концентрации свинца и цинка (более 60 и 30 , соответственно). Процесс снятия богатой серебристой пены крановой шумовкой и последующее грохочение сопровождаются значительным запылением, что приводит к нарушению санитарно-гигиенических условий в цехе, а также потерям ценных компонентов.

С целью определения возможности использования данных центрифуг были проведены операции центрифугирования на стадии обессеребрения чернового свинца. Предварительные испытания обессеребрения путем вмешивания цинка при температуре $500-430^{\circ} \mathrm{C}$, расплав охлаждают до $440-400^{\circ} \mathrm{C}$, при введении в него оборотной серебристой пены предыдущей операции отделяют и направляют на переработку богатую серебристую пену, при охлаждении расплава от 380 до $350^{\circ} \mathrm{C}$ снимают оборотную пену. Это позволяет снизить выход оборотов на 6-8,8\% [41.2].

Авторы работы [42.2] сравнением состава и структуры серебристой пены, полученной центрифугированием и снятой шумовкой, показали, что продукты аналогичны по минеральному составу, но различаются крупностью материала и количественным соотношением фаз в зернах и сростках. Продукт центрифугирования представляет собой сыпучий материал крупностью частиц не более 10 мм. Выход фракции $+2,5$ мм составляет 5-7\%. Опытно-промышленные и промышленные испытания проводили на операции снятия богатой серебристой пены непосредственно 
в рабочем технологическом цикле рафинировочного цеха в котлах ёмкостью 310 т с использованием в режиме испытаний аппаратов ПАФВС-1200-1у конструкции СКБ ГИТ СО АН СССР и ПАФВС-1200-2у. В ходе промышленных испытаний [43.2; 44.2] отрабатывалась конструкция аппарата, определялись надёжность и работоспособность основных технологических узлов агрегата, а также технологические режимы процесса.

Проведенные испытания дали следующие результаты: выход богатой серебристой пены составил $2 \%$; содержание свинца в ней снижено в среднем до 50,95\% против 61,80\% по существующей технологии;

- содержание цинка снижено в среднем до $26,8 \%$ против $32,0 \%$ соответственно;

- в получаемой богатой серебристой пене возросло в 2 раза содержание фракции с повышенными концентрациями благородных металлов.

Полученный материал пены представлял пескообразный относительно однородный продукт, не требующий грохочения, поэтому его сразу направляли на переработку в купеляционное отделение. Время операции снятия богатой серебристой пены центрифугой составляет в среднем 1 час, с учётом подготовительных работ - 1 час 15 мин. Это несколько выше, чем с использованием крановой шумовкой. Однако высвобождение крана, автоматический режим работы агрегата и, главное, ликвидация операции грохочения даёт очевидное преимущество центрифугированию.

Проведенные испытания показали, что использование центрифугирования на операции обессеребрения свинца может повысить экономические показатели, обеспечить повышение автоматизации и механизации процесса на данной стадии рафинирования. Тем не менее, постоянные сбои, аварийные поломки и остановки практически на каждой операции, необходимость очистки расплава от «якорей» и их обломков дали основание считать данную конструкцию недоработанной и недостаточной для внедрения.

Проведенные исследования, опытно-промышленные и промышленные испытания показали перспективность практического использования центрифугирования на операциях рафинирования чернового свинца УК СЦК. Однако, этот вопрос полностью определяется надёжностью аппаратуры, обеспечивающей бесперебойную эксплуатацию её в условиях технологического процесса свинцового производства. Как показали опыты, проведенные Гидроцветметом и УК СЦК, центрифуга ПАФВС-650 может быть применена на операциях рафинирования чернового свинца в определённых технических условиях, определяемых возможностями её работы на котлах ёмкостью до 50 т $\mathrm{Pb}$. 


\section{ПОСЛЕСЛОВИЕ}

При финансовом содействии Минцветмета институт Гидроцветмет и УКСЦК выполнили значительный объем работ по разработке центробежной фильтрации на разных стадиях рафинирования свинца. Значительный вклад в эти работы внесли Багаев И.С., Копылов Н.И., Огнев Ю.Г. Поэтому по рекомендации рецензента описание работ института Гироцветмета выделено из общего обзора в отдельный раздел. 


\section{ЦИТИРУЕМАЯ ЯИТЕРАТУРА}

1. Мурач Н.Н., Металлургия олова, М.: Металлургиздат,1947, 251 с.

2. Мурач Н.Н., Севрюков Н.Н., Полькин С.И., Быков Ю.А. Металлургия олова, М.: Металлургиздат, 1964, 351.

3. А.с. 335978 СССР Способ рафинирования олова / Сутурин С.Н, Бауэр Е.Т., Воронков Н.А., Гавриленко Д.И., Двуреченская Е.Д., Клещенко Н.С., Перкис Л.В., Пулькин П.П., Роднин Ю.Р. Новосибирский оловокомбинат; заявка № 958134 от 09.05.1964, М.кл С22 b9/02; Оф. бюл. «Откр, изобрет», М., опуб.29.01.2019; БИ № 4-2019.

4. А.с.379288 - Вертикальная центрифуга для разделения суспензий / Деев С.Л., Берляков В.Н, Роднин Ю.Р., Звонков Ю.Ф., Сутурин С.Н. Новосибирский оловокомбинат, заяв № 1379612 от 27.11.1969, Мкл В04в3/04; опуб, 20.04.73, М. ЦНИИПИ, БИ № 20-73.

5. Pearce S.C. Developments in the smelting and refining of tin. (Процессы плавки и рафинирование олова) «Lead-Zink-Tin'80: Proc. World Symp. Met. and F-nviron. Contr: 109th. AIME Annu. Meet., Las Vegas, Nev, Febr. 24-28, 1980». New York, N. Y., 1979, p. 754-770.

6. Muller B., Pachen P. Trends in smelting and refining of impure and complex tin concentrates «Complex metallurgy-78», I978, p. 82-90.

7. Bureau of Mine Report of Investigations, N.-Y. 1976, 7602, p. 1-9.

8. Арзамасцев Ю.С. Дьяков В.Е., Семенов А.Е., Сутурин С.Н. Новые процессы рафинирования олова, М.: Цветметинформация, 1980, 39 с.

9. А.с. СССР 463334 Аппарат для рафинирования расплавленных металлов от нерастворимых примесей / Сутурин С.Н., Бауэр Е.Т., Семенов А.Е., Дьяков В.Е., Деев С.Л., Перкис Л.В., Коновалов Л.В., Войцеховский Б.В., Долгов Л.В., Новосибирский оловозавод; Институт гидродинамики СО АН СССР - заявл № 1374168 от 4.11.69; МПК4 С22b9/02 // Оф. бюл. «Открытия, изобретения», М.: Опубл. 25.06.77, Би № 23 с. 201.

10. А.с. СССР 306680-Центрифуга / Долгов А.В., Институт гидродинамики СО АН СССР заявка № 1197564 от 20.11.67; М.кл В04в 3/02; Опубл. 25.06.77, Оф. бюл. «Открытия, изобретения», М., Би № 23 с. 201.

11. А.c. СССР 398281; Фильтрующая центрифуга / Долгов А.В. СКБ ГИТ СО РАН, заявка № 1629152 от 2.03.71-М.кл В04в3/02; Опубл. 27.09.73, Оф. бюл. «Открытия, изобретения», М. ЦНИИПИ, Би№ 38-73.

12. А.c. СССР 461647 Способ центробежного рафинирования расплавленных металлов / Долгов А.В., СКБ ГИТ СО РАН, заявка 
№ 1636140 от 31.03.71; М.кл.С22в9/02; Опубл. 5.06.77, Оф. бюл. «Открытия, изобретения», М. ЦНИИПИ, Би№ 21-77.

13. Долгов А.В., Сутурин С.Н., Хрипунов А.С. Рафинирование металлов на погружной центрифуге // Цветные металлы, М., 1977, № 7, с. 5-8.

14. Долгов А.В., Дьяков В.Е., Бурда Яросл., Вурм К. Промышленные испытания центробежной фильтрации свинца на предприятии «Ковогута» (ЧСФР) // Цветные металлы, 1990, № 11, с. 41-44.

15. Черкасский Р.И., Кувшинов В.А., Гончарова Р.Я. Дьяков В.Е., Сутурин С.Н. Регенерация олова из оловосодержащих отходов горячего лужения методом центробежной фильтрации // Сталь, 1982, № 6, с. 52-54.

16. Wright P.A. Extractive metallugy of tin. Amsterdam, N.-Y. 1982, p. 300.

17. Дьяков В.Е Окисление металлической пены на поверхности при центробежной фильтрации расплавленного олова // Научный альманах 2016, № 10(3), c. 110-120, DOI: 10,17117/na.2016.10.03.110.

18. Дьяков В.Е Окисление кристаллов примесей при центробежной фильтрации // Цветная металлургия № 6 2016. С. 18-27.

19. Дьяков В.Е. Совершенствование технологии рафинирования расплава олова от мышьяка фильтрацией // Научный альманах, Тамбов, Изд. Юком, 2016, № 8-1 (22), с. 208-216; ISSN-2411-7609; DOI: 10.17117/ na. 2016.08.01.208.

20. Дьяков В.Е. Центробежная фильтрация расплавленных пленок олова с твердых кристаллов // Научный журнал «Chronos», VI Международной научной конференции, М., 2016, ч. 1, с. 99-104.

21. Сутурин С.Н. Автореферат диссертации на соискание к.т.н «Центробежное рафинирование олова от примесей», 1969.

22. Авт.св.СССР №840176, Способ переработки оловянных материалов / Дьяков В.Е., Сутурин С.Н., Долгов В., Черкасский Р.И., Климентов Б.В., Кувшинов В.А., Литовченко А.П., Кашарнов Н.П., Садыков 3.Г., Сулаков В.П., опуб. Би23-81-112.

23. Авт. св. СССР№ 790808, Способ переработки оловянных материалов / Сутурин С.Н., Дьяков В.Е., Долгов А.В., Черкасский Р.И., Климантов Б.В., Кувшинов В.А., Литовченко А.П., Кашарнов Н.П., Садыков 3.Г., Сулаков В.П., Гольдман А.Г. Магнитогорский металлургический комбинат, Институт гидродинамики СО АН СССР, Новосибирский оловянный комбинат / заявка № 2803778, от 02.08.1979; Опуб 10.11.2011, Би 31-11-с. 1126.

24. Авт.св.СССР № 896920 Способ выплавки олова из оловосодержащих материалов / Дугельный А.П., Дьяков В.Е., Корюков Ю.С., Семенов А.Е., Сутурин С.Н., Двуреченская Е.Д., Новопашин А.И., Швед Г.Е., Черкасский Р.И., Кувшинов В.А., Климантов Б.В., Новосибирский оловянный комбинат // заявка № 2974172 от 19.08.1980. Опубл 10.03.2012 Бюл. № 7. 
25. Дьяков В.Е.Совершенствование технологии рафинирования расплава олова от мышьяка фильтрацией // Scientia.Техника, М., 2016 № 4. C. 24-29.

26. Свойства неорганических соединений: справочник; под ред. А.И. Ефимова, М., 1983, 392 с.

27. Хансен М., Андерко К. Структура двойных сплавов. - Т. 1. - М.: Металлургиздат, 1962. - 350 с.

28. Хансен М., Андерко К. Структура двойных сплавов. - Т. 2 - М.: Металлургиздат, 1962. - 1488 с.

29. Дьяков В.Е., Корюков Ю.С., Новопашин А.И. Обобщение опыта эксплуатации центробежного рафинирования олова от железа, мышьяка // Соверш. технол. перераб. оловосодерж. сырья: сб. науч. тр. ЦНИИОлово. Новосибирск, 1987, 54-5, реф. 2Г170-М88.

30. Пат 2093594 РФ, Центрифуга фильтрации расплавленного металла / Дугельный А.П., Закшевский В.И., Стекленев В.М., Галкин Е.А., Дьяков В.Е., ОАО Новосибирский оловянный комбинат - заявка № 4939509 от 24.05.1991; МПК6 С22b 9/02; Опубл. 20.10.1997, БИ№ 29 с. 313.

31. Брандт К.Х. Технологические исследования по удалению железа, мышьяка и висмута из олова зейгерованием интерметаллическим осаждением // Freiberg Forschungoh, 1970, B, № 156, p. 35-72.

32. Арзамасцев Ю.С., Богданов В.А., Богданов Вл.А., Дьяков В.Е., Лебедев И.С., Роднин Ю.Р., Сутурин С.Н..Семенов А.Е. Совершенствование технологии производства и рафинирования олова в СССР Бюл. научно-технического совета по металлургии тяжелых цветных металлов, Гливице ПНР, Бюл. науч. технич. Совета по металлургии тяж.цвет.метал, 1981, № 13, c. 21-26.

33. Лебедев И.С., Дьяков В.Е., Теребенин А.Н., Комплексная металлургия олова, Новосибирск, 2004, 548 с.

34. Автб св СССР 921263 Способ рафинирования олова от примесей / Дьяков В.Е., Семенов А.Е., Соловьев Б.А., Селиванов И.М., Дутельный А.П., Зыкус М.Ю., Никитина В.Д., Галкин Е.А.; НОК, опубл. БИ.№ 21, 1986. с. 260.

35. Авт. св. 611538 СССР Способ рафинирования олова от свинца и алюминия / Дьяков В.Е., Корюкова Л.М., Лелюк В.Г., Степанов Г.И., Новосибирский оловянный комбинат, заявка № 2461236 от 09.03.77. Опуб. 07.10.1992., БИ№ 37.

36. А.с. 784364 СССР Способ рафинирования олова от примесей / Сутурин С.Н., Корюков Ю.С., Дьяков В.Е., Дугельный А.П.; Новосибирский оловянный комбинат // Заявл. 12.07.79, № 2794750, опубл. Б.И:№ 21-86.

37. А.с. 588762 СССР Способ рафинирования олова от сурьмы и мышьяка / Дьяков В.Е., Лелюк В.Г., Корюкова Л.М., Степанов Г.И.; 
Новосиб. оловян. комб, МКИ С 22 В 25/08 //. Заявл. 01.09.76, № 2402094, опуб Б.И., 1986, № 21.

38. Богданов В.А., Дьяков В.Е., Роднин Ю.Р. Об образовании мышьяковистого водорода в оловянном производстве и мероприятия по предотвращению его выделения // Науч труды ЦНИИолово № 1, 1973, с. 72-74.

39. Корюков Ю.С., Дьяков В.Е., Сутурин С.Н. Повышение эффективности использования процесса центробежного рафинирования олова и снижение циркуляции мышьяка // Совершенствование технологической схем обогащения и металлургии олова: науч.тр. ЦНИИолова, 1981, с. 68-71.

40. Диаграммы состояния двойных металлических систем, Справочник, т. 1, под общ. ред. Н.П. Лякишева, М.: Машиностроение, 1997, с. 1024 . стр. 263.

41. Авт.св.№ 647942 Способ рафинирования олова от примесей / Дьяков В.Е., Корюков Ю.С., Сутурин С.Н., Двуреченская Е.Д., Лелюк В.Г., Заявка № 2513892 от 08.08.77 // опуб БИ № 7-2012, с.3 80.

42. Заявка РФ№ 2018119650 Способ рафинирования олова от мышьяка и электролизер его осуществления / Дьяков В.Е. // опубл.заявки: 23.07.2018 Бюл.№ 21.

43. Дьяков В.Е., Дьяков Б.Н. Электроэкстракция индия на вакуумном аппарате рафинирования олова // Научный журнал «Globus», технические науки: сб. науч. публ., V международная научно-практическая конференция», Техические науки-от теории к практике», СПб., 2016, стр. 53-58.

44. Дьяков В.Е. Электроэкстракция мышьяка с железом из расплавленного олова // Научный альманах Технические науки № 10. 2(48). 2018, Тамбов, изд ООО «Консалт комп Юком» (ISSN 2411-7609); DOI: 10.17117/na.2018.10.02.035.

45. Дьяков В.Е., Варнек В.А, Исследование продуктов рафинирование олова от мышьяка хромом // Цветные металлы, 1985, 9, с. 33-35.

46. Эллиот Р.П. Структура двойных сплавов. Т. 1. М.: Металлургия, 1970. 455 с.

47. Шанк Ф. Структура двойных сплавов. М.: Металлургия, 1973. 420 с.

48. Авт. св СССР 408565 Способ рафинирования олова от примесей / Сутурин С.Н., Двуреченская Е.Д., Семенов А.Е., Корюков Ю.С., Дьяков В.Е., Клещенко Н.С., Звонков Ю.Ф., Самоделов А.П. // опуб 7.10.92. Би 37-1992.

49. Авт. св СССР № 611539-Способ рафинирования олова от мышьяка / Сутурин С.Н., Корюков Ю.С., Дьяков В.Е., Двуреченская Е.Д., Семенов А.Е., Лелюк В.Г., Степанов Г.И. // Оп.7.10.92; БИ 37-1992. с. 227.

50. Моисеев Г.К., Ватолин Н.А. Некоторые закономерности измерения и методы расчета термодинамических свойств неорганических соединений, Екатеринбург: УрО РАН, 2001, с. 128. 
51. Лукашенко Г.М. Термодинамические свойства интерметаллических фаз: сб. науч. тр. Киев: ИПМ АН УССР, 1982, 169 с.

52. Авт.св. СССР 902473. Устройство для рафинирования расплавленных металлов / Дугельный А.П., Токарев Г.И., Соловьев Б.А., Степанов Г.И., Дьяков В.Е., Селиванов И.М., Корюков Ю.С., Сутурин С.Н., Новосибирский оловянный комбинат // опубл. 10.03.12, Би7 с. 59.

53. Дьяков В.Е. Рафинирование олова от мышьяка магнитогидродинамическим разделением пены и олова // Научный альманах·2018 № 6-2(44); Тех наук с26 - DOI: 10.17117/na.2018.06.02.026.

54. Аршинников В.А., Федосеев В.П., Решетко Н.К. Рафинирование олова от железа и мышьяка электромагнитным методом // Ученые записки № 3 ЦНИИолова «Электролитическое получение и рафинирование тяжелых цветных металлов в расплавах», ч. 2 Технологические исследования, Новосибирск, 1970, с. 35-38.

55. Дьяков В.Е. Поведение кристаллов примесей олова в центробежном поле» // Научный альманах, Тамбов, Юком. 2016. 11(2)(25), с. 107-115.

56. Справочник химика. т. 5. М.: Химия, 1964; с. 248.

57. Углев Н.П. О центрифугирования металлических расплавов // Металлы № 2, 1987, с. 45-46.

58. Авт св СССР№ 944349 Устройство для рафинирования расплавленных металлов / Дьяков В.Е, Сутурин С.Н., Семенов А.Е, Корюков Ю.С / Новосибирский оловянный комбинат // Опуб. 27.11.96., Би№ 33-1996. с. 234.

59. Дьяков В.Е. Регенерация цветных металлов из отходов центробежной фильтрацией, монография, М.: ИД.Библио-Глобус, 2018, 116 с. ISBN: 978-5-6040673-7-6; DOI: 10.18334/9785604067376.

60. Пат РФ № 1559734 Устройство рафинирования расплавленных металлов / Дьяков В.Е., Сутурин С.Н., Долгов А.В., Корюков Ю.С., Новопашин А.И, Галкин Е.А. / Новосибирский оловянный комбинат // Опуб БИ № 12.-2013. с. 603.

61. Авт. св. СССР, 936630; Способ рафинирования олова от мышьяка / Сутурин С.Н., Дьяков В.Е., Корюков Ю.С., Семенов А.Е., Дугельный А.П., Двуреченская Е.Д., Степанов Г.И. / Новосибирский оловянный комбинат, С22b25/08; заявка № 2891161 от 10.03.1980 // Оп: 10.11.11. № 31-11. с. 1126.

62. Авт. св. СССР № 671410, 2547422,28.11.1977, Способ рафинирования олова от мышьяка / Сутурин С.Н., Корюков Ю.С., Дьяков В.Е., Двуреченская Е.Д., Дугельный А.П., Лелюк В.Г. / Новосибирский оловянный комбинат, С22В25/08 // Опуб.10.11.2011, БИ№ 31-2011, с. 1128.

63. Кислицин А.Н. Пиролиз древесины: химизм, кинетика, продукты, новые процессы. М.: Лесная промышленность, 1990. 311 с. 
64. Дубинин М.М. Пористая структура активных углей и кинетика адсорбции // Углеродистые адсорбенты и их получение в промышленности: сб. Наука, 1983, с. 116-125.

65. Авт. св. СССР № 788768, Способ переработки мышьяковистых съемов рафинирования олова / Макаров Г.С. Дьяков В.Е, Корюкова Л.М, Несмелов В.Н., Алексеева Н.К, заявка № 2779169 от 13.06.1979, Опуб 07.10.1992-БИ37-92. с. 227.

66. Авт. св. СССР №653923, Способ переработки оловосодержащих материалов / Дьяков В.Е., Сутурин С.Н., Кожнова Р.В., Корюков Ю.С. // заявка № 2523114 от 08.29.1977; С22В25/02 // опуб. 10.03.12, № 7-12. с. 379 .

67. Дьяков В.Е. Регенерация припоев из отходов центробежной фильтрацией // Инновац внед в обл техн наук: сборник научных трудов по итогам международной научно-практической конференции, Эвенсис, М., 2017, вып. 2, с. 21-28.

68. Дьяков В.Е. Регенерация припоев из отходов печатных плат центробежной фильтрацией // Современные тенденции развития науки и технологии: научный сборник. АПНИ, Белгород, 2017, № 3, ч. 4, стр. 23-27.

69. Авт. св. СССР № 923197 Аппарат центробежной фильтрации расплава от твердых примесей / Сутурин С.Н., Семенов А.Е., Бауэр Е.Т., Дьяков В.Е., Корюков Ю.С., заявка № 3008542 от 24.11.80; М. кл С22b9/02; опубл 10.12.1996; Би34-96-251.

70. Авт. св. СССР1734385 Центрифуга фильтрации расплава / Дьяков В.Е., Дугельный А.П., Опутин В.Г., Корюков Ю.С., Попенков А.З., Новосибирский оловянный комбинат, заявка № 4822839 от 21.03.90. С22В9/02 // опуб 27.06.11. би18-11. с. 1081.

71. Пат РФ№ 2035236; Устройство для фильтрации расплавов / Дьяков В.Е., Дугельный А.П., Корюков Ю.С. Новосибирский оловянный комбинат, заяв. №4948851; от 24.06.91; В04b1/14 // Опубл 20.05.95; БИ14-95. с. 108.

72. Авт. св. СССР 479810 Аппарат для вмешивания в расплав цветных металлов / Сутурин С.Н, Долгов А.В., Дьяков В.Е., Двуреченская Е.Д., Корюков Ю.С., Семенов А.Е., Степанов Г.И.,, Новосибирский оловянный комбинат, заявка № 1968875 от 5.11.73. С22b13/06 // опуб. 5.08.75; БИ 29-1975, с. 86.

73. Сутурин С.Н., Семенов А.Е., Дьяков В.Е. Разработка и виедрение непрерывных высокоэффективных процессов глубокой очистки олова с комплексным извлечением сопутствующих металлов и исключеннием загрязнением окружающей среды // Цветные металлы, М., 1979. № 8 c. 26-30. 
74. Дьяков В.Е., Семенов А.Е., Селиванов И.М. Особенности извлечения индия из оловянного сырья // «Цветные металлы» М,1980, № 6, c. 30-31.

75. Покровский В.В. Распределение индия в продуктах подготовительного и плавильного переделов оловянного завода // Науч. тех. бюл. «Цветная металлургия», 1965, № 8, с88-89.

76. Авт.св.СССР 609336 Способ переработки материалов, содержащих олово, индий и цинк / Дьяков В.Е., Семенов А.Е., Корюкова Л.М. / Заявка № 2304244 от 29.12.75 // опуб 10.03.12-БИ7-12. с. 379.

77. Авт.св. СССР 540929 - Способ переработки цинксодержащих оловянных пылей / Дьяков В.Е., Роднин Ю.Р., Макаров Г.С., Корюков Ю.С.; НОК, заявка №2194730-от 27.11.1975 // опубуб. 30.12.1976. БИ№ 48-1976. с.83.

78. Авт. св. СССР 917546-Способ извлечения индия из пылей / Дьяков В.Е., Алексеева Н.К., Черешнев С.М., Мухин Н.И., Завозин Н.И. / заявка № 2990840-от 3.10.80 // опуб. 27.06.11. Би18-11. с. 1082.

79. Авт. св. СССР 867056 Способ вакуумного рафинирования олова заявка / Сутурин С.Н., Клевакин А.А., Семенов А.Е., Дьяков В.Е., Хороших Н.Н. / заявка № 2363504 от 19.05.1976 // опуб. 10.11.2011БИ№ 31-2011.

80. Пат РФ№ 2490375 Электролизер для извлечения индия из индийсодержащего расплава в виде конденсата из вакуумной печи / Дьяков Б.Н. / Заявка: 2012128709, от 09.07.2012 // опубл. 20.08.2013.

81. Дьяков В.Е. Поведение индия при центробежной фильтрации расплавленного олова // Научный альманах (Технические науки) Тамбов, изд Юком, 2016, № 12-2(26) с. 45-50; DOI: 10/17117/na.2016.12.02.045. 


\section{ЦИТИРОВАННАЯ ЯИТЕРАТУРА К ГЛАВЕ 2}

1.2. Смирнов М.П. Рафинирование свинца и переработка полупродуктов, М.: Металлургия, 1977, 280 с.

2.2. Гудима Н.В., Шейн Я.П. Краткий справочник по металлургии цветных металлов. М.: Металлургия, 1975, 534 с.

3.2. А. с. СССР 335978-Способ рафинирования олова / Сутурин С.Н., Бауэр Е.Т., Воронков Н.А., Гавриленко Д.И., Двуреченская Е.Д., Клещенко Н.С., Перкис Л.В., Пулькин П.П., Роднин Ю.Р. Новосибирский оловокомбинат; заявка № 958134 от 09.05.1964; М.кл С22 b9/02; // опуб. 29.01.2019, БИ № 4, 2019.

4.2. Чумак 3.Н. Разработка и внедрение высокоэффективного оборудования и технологии комплексной переработки оловосодержащего сырья // Цветные металлы, 1985, № 10, с. 19-21.

5.2. А.с. СССР 379288 Вертикальная центрифуга для разделения суспензий / Деев С.Л., Берляков В.Н., Роднин Ю.Р., Звонков Ю.Ф., Сутурин С.Н.; Заявитель: Новосибирский оловокомбинат, м.кл В04b3/04; заявка № 1379612 от 27.11.1969 // опуб 20.04.1973; БИ № 20.

6.2. Сутурин С.Н., З Звонков Ю.Ф., Роднин Ю.Р., Рафинирование свинца путем фильтрации // М., Цветная металлургия, № 12, с. 25.

7.2. А.с. СССР 463334, Аппарат для рафинирования расплавленных металлов от нерастворимых примесей / Сутурин С.Н., Бауэр Е.Т., Семенов А.Е., Дьяков В.Е., Деев С.Л., Перкис Л.В., Коновалов Л.В., Войцеховский Б.В., Долгов Л.В., Новосибирский оловозавод; Институт гидродинамики СО АН СССР / Заявл. 4.11.69; № 1374168; МПКС22b9/02; Опубл. 25.06.77, Би № 23 с. 201.

8.2. Долгов А.В., Сутурин С.Н., Дьяков В.Е. Ценробежное рафинирование свинца от меди // Цветные металлы, 1978, № 6, с. 3-5.

9.2. Дьяков В.Е. Регенерация цветных металлов из отходов центробежной фильтрацией: монография; М., Библио-Глобус, 2018; с. 116 DOI: 10.18334/9785604067376.

10.2. Долгов А.В., Сутурин С.Н., Хрипунов А.С. Рафинирование металлов на погружных центрифугах // Цветные металлы, М., 1977, № 7 , с. 5-8.

11.2. Ходов Н.В, Сутурин С.Н., Мешков Е.И., Дьяков В.Е., Долгов А.В. Центробежное обезмеживание свинца на заводе Электроцинк // Цветная металлургия. 1982. № 6. с. 22-24. 
12.2. А.с. СССР 753149, Способ непрерывного рафинирования свинца и установка для его осуществления // Долгов А.В., Сутурин С.Н., Дьяков В.Е. Заявители: Ордена Трудового Красного Знамени институт гидродинамики СО АН СССР. Новосибирский ордена Ленина оловянный комбинат / Заявка № 2729241 от 26.02.1979, МПК С22В 13/06; Опуб. 10.11.2011 БИ № 31.

13.2. Дьяков В.Е. Рафинирование свинца от меди центробежной фильтрацией расплава // Научный альманах 2018 №9-2(47) Тех. науки, Тамбов, изд. Юком (ISSN 2411-7609), с19-28.DOI: 10.17117/ na.2018.09.02.019.

14.2. А.c. СССР 928814; Способ непрерывного обезмеживания чернового свинца и устройство его осуществления // Копылов Н.И., Пашков Г.Л., Бейлин Я.З., Шабрин А., Дьяков В.Е., Сутурин С.Н., Долгов А.В., Огнев Ю.Г., Шешуков Г.Ф., Битаров Ч.Д. / Заяв. № 2918365 от 30.04.80; МПК С22b13/06; опуб. 10.11.11. № 31-11. с. 1126.

15.2. Долгов А.В., Дьяков В.Е., Бурда Ярослав, Вурм К. Промышленные испытания центробежной фильтрации свинца на предприятии «Ковогута» (Чехия) // Цветные металлы, 1990, № 11, с. 41-44.

16.2. А.с. СССР 824660; Способ обезмеживания свинца // Долгов А.В., Сутурин С.Н., Дьяков В.Е., Ходов Н.В., Цаболов Ю.А., Хугаев Х.Т., Хугаев В.И., Себетов Х.З. Заявители: Завод «Электроцинк», ИГД СО АН, Новосибирский оловянный комбинат; МКИ С22В13/06, Заявл. № 2523287 от 06.09.77. Опубл. 10.08.2014; БИ№ 22.

17.2. Пат РФ 2630070 - Способ рафинирования свинца от меди и центробежный аппарат его осуществления // Дьяков В.Е., Заявка № 2016144226 от 10.11.2016; М.кл.С22 b9/02, Опуб пат: 05.09.2017, БИ.№ 25.

18.2. Авт. св. СССР № 989884 / Дьяков В.Е. Способ рафинирования сурьмы от примесей, Опуб 10.03.2012; Би№ 7-2012. с. 381.

19.2. Авт. св. СССР № 1015674 / Дьяков В.Е., Корюков Ю.С., Яковлев М.А., Зыкус М.Ю. Способ переработки индиевых отходов и устройство для его осуществления; Опубл 10.11.2011; № 31-2011. с. 1127.

20.2. Пат РФ № 1216233-заявка № 3683867 от 17.10.1983 / Дьяков В.Е., Способ регенерации щелочи из щелочных плавов от рафинирования свинца; Мкл С22В13/06 // Опуб 07.03.1986, БИ № 9-1986. с. 118.

21.2. Дьяков В.Е. Регенерация щелочи из плавов щелочного рафинирования свинца центробежной фильтрацией // Научный альманах, изд. Юком ISSN 2411-7609, 2017, № 3-3(29), стр. 83-90, DOI: 10.17117/ na2017.03.03.83-90. 
22.2. Пат РФ 2653894. Способ щелочного рафинирования свинца и аппарат его осуществления / Дьяков В.Е. / заявка 2017113634 от 19.04.17; МПК_С22В 13/06 // опуб. пат БИ 14-18.15.05.

23.2. Авт. св. СССР№ 1172276 Устройство центробеж фильтрации расплав / Дьяков В.Е. // Опуб.27.06.11. Би № 18-2011. с. 1081.

24.2. Чекушкин В.С., Олейникова Н.В. Щелочная плавка в процессах восстановления и экстракции тяжелых цветных металлов, Красноярск: КрИЖТ, ИрГУПС, 2011, 331 с.

25.2. Bureau of Mine Report of Investigations, N.-Y. 1976, 7602, p. 1-9.

26.2. Muller B., Pachen P. Trends in smelting and refining of impure and complex tin concentrates //Complex metallurgy-78, 1978, p. 290.

27.2. Соболь Н.Ф., Милентьева В.И. Рафинирование свинца за рубежом, М.: Цветметинформация, 1977, с. 51.

28.2. Авт св СССР№944349; Устройство для рафинирования расплавленных металлов / Дьяков В.Е, Сутурин С.Н., Семенов А.Е, Корюков Ю.С. // Опуб. 27.11.96., Би № 33-1996. с. 234.

29.2. Смирнов М.П., Виноградов С.В., Копач В.Г. Обогащение висмутистых дроссов центрифугированием // Цветные металлы № 11, 1990, с. 44-45.

30.2. Авт. св. СССР№ № 549991 Способ электрохимического разделения висмутистого свинца / Делимарский Ю.К., Зарубицкий О.Г., Бровин И.П., Будник В.Г., Бровина О.И., Дубравин В.И., Заявители - ИОНХ УАН, Дальполиметалл; заявка № 2047616 от 29.04.74 // опуб 25.10.77; БИ 39-1977.

31.2. Авт. св. СССР№ 770221 Способ извлечение висмута из висмутистого свинца / Сутурин С.Н., Дьяков В.Е., Двуреченская Е.Д., Долгов А.В., Глушков И.В., Меринов М.Ф., Бровин И.Д., Саввин В.Д., Захаров Б.Н., Заявители НОК, ИГД СО РАН, Дальполиметалл; заявка № 2768831 от 17.05.79. МПК С22в13/06 // Опуб 10.11.2011.

32.2. Пат РФ№ 2096532 -Электролизер разделения сплавов свинца с висмутом / Дьяков В.Е., Заявка № 96103873 от 1996.02.27 / МПК С25с7 / публ. 1998.02.27 БИ 32-97. с. 286.

33.2. Дьяков В.Е. Опыт освоения производства висмута электролизом в расплаве солей // Комплексное использование минерального сырья, 2012, № 1, с. 37-43.

34.2. Пат РФ№ 2471893-Способ электролитического получения висмута из сплава, содержащего свинец и олово и висмут и электролизер для его осуществления / Дьяков В.Е заявка№ 2011140970, от 07.10.2011 С25C 3/34; C25C 7/00 // Опубл. пат: 10.01.2013 Бюл. № 1-2013.

35.2. Пат России №2083707, Способ переработки отходов висмута свинца / Дьяков В.Е., заявка №94006916 от 1994.02.24; МПК С22В30/06 // опуб. 1995.12.10 БИ № 19-1997. 
36.2. Летягин Ю.И., Копылов Н.И., Пашков Г.Л., Костенецкий В.П., Сутурин С.Н., Долгов А.В., Дьяков В.Е. Удаление мышьяка из расплава свинца при центробежном рафинировании // Проблемы мышьяка в производстве цветных металлов, методы его вывода, обезвреживания и утилизации: тез. докл.; под общ. ред. Л.К. Чучалина. М.: ЦНИИцветмет, 1979, с. 56.

37.2. Копылов Н.И., Пашков Г.Л., Бейлин Я.3., Шешуков Г.Ф., Летягин Ю.И. Опытно-промышленные испытания центрифуги ПАФВС-650 на стадии обезмеживания свинца // Цветные металлы, 1983, № 5, с. 30-31.

38.2. Копылов Н.И., Смаилов С.Д., Смирнов М.П. Комплексная технология непрерывного обезмеживания чернового свинца // Цветные металлы, 1995, № 11, С. 17-20.

39.2. Летягин Ю.И., Копылов Н.И., Чучалин Л.К., Багаев И.С., Бейлин Я.З., Пашков Г.Л, Семенов А.Е., Обезмеживание чернового свинца с использованием центробежной фильтрации, с. 105-107 // Физико-химия и технология свинца: сб. т. 2. Основы комплексного использования сырья и переработки полупродуктов: материалы 3 республиканской конференции, тез. док. Алма ата, 1984. 176 с.

40.2. Копылов Н.И., Пашков Г.Л., Летягин Ю.И., Костенецкий В.П., Бейлин Л.3., Шешунов Г.Ф. Применение метода центрифугирующей фильтрации при обезмеживании свинца // ж. Цветные металлы, № 7-1982, с. 19-21.

41.2. А.с. СССР № 1555386 - Способ обессеребрения свинца / Копылов Н.И., Летягин Ю.И., Семенов А.Е., Багаев И.С., Маценко Ю.А., Богданов В.В., Нурбаев М.А, Кишибеков Н.К., Заявитель - Государственный научно-исследовательский и проектно-конструкторский институт гидрометаллургии цветных металлов (Гидроцветмет), Усть-Каменогорский свинцово-цинковый комбинат им. В.И. Ленина (УКСЦК), Заявлено: 4393913 от 13.01.1988; С22В 13/06 // Опубл: БИ № 13, 07.04.1990.

42.2. Пестунова Н.П., Копылов Н.И.,. Летягин Ю.И,. Интыкбаев А.М. Состав серебристой пены при центрифугировании свинца // Комплексное использование минерального сырья, № 11-1986, стр. 56-58.

43.2. Летягин Ю.И., Копылов Н.И., Чучалин Л.К., Семенов А.Е., Интикбаев А.М., Шишиков Г.Ф., Слободкин Л.В. Усовершенствование процесса обессеребрения свинца // Физико-химия и технология свинца: тез. матер. 3-й Республ. конф. / Т. 2. Алма-Ата: Наука Каз СССР, 1984, С. 95-96.

44.2. Летягин Ю.И,.Копылов Н.И., Слободкин Л.В., Пестунова Н.П., Интыкбаев А.М.,. Чирик Я.И. Обессеребрение свинца с использованием центробежной фильтрации // Цветные металлы, № 11, 1986, стр. 20-21. 


\section{ОГЛАВЛЕНИЕ}

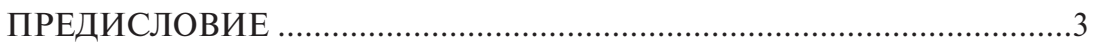

\section{Глава 1. ЦЕНТРОБЕЖНАЯ ФИЛЬТРАЦИЯ}

РАСПЛАВЛЕННОГО ОЛОВА ..............................................

1.1. Основы ликвационного рафинирования

и обзор работ по фильтрации олова.........................................4

1.2. Кинетика центробежной фильтрации олова от железа ...........14

1.3. Центробежная фильтрация олова от мышьяка с железом ........18

1.3.1. Кинетика очистки олова от мышьяка с железом

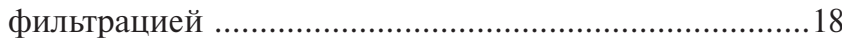

1.3.2. Циркуляция расплава через фильтр..............................21

1.3.3. Выход олова в съемы при разном соотношении $\mathrm{Fe} / \mathrm{As}$...................................................22

1.3.4. Термодинамика и физико-химические исследования фаз мышьяка в олове ...........................23

1.3.5. Толщины пленки олова на кристаллах и укрупнение частиц кристаллизацией ........................25

1.3.6. Промышленные испытания центробежной фильтрации AsFe и сравнение с ликвационным

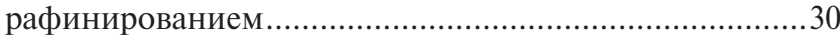

1.3.7. Сравнение центробежной фильтрации олова с ликвационным рафинированием от железа

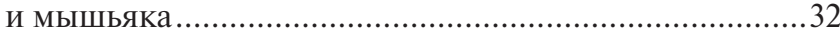

1.4. Сопоставление вариантов удаления остаточного

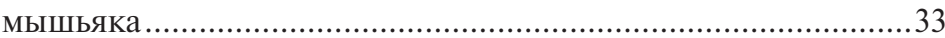

1.4.1. Недостатки удаления мышьяка с алюминием .............33

1.4.2. Сравнение способов связывания мышьяка

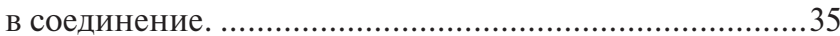

1.4.3. Удаление остаточного мышьяка с железом ...................37

1.4.4. Удаление остаточного мышьяка с хромом.....................40

1.4.5. Удаление остаточного мышьяка с марганцем ..............43 
1.5. Экстракция остатков мышьяка с марганцевой пеной

1.5.1. Условия образования пены соединений мышьяка

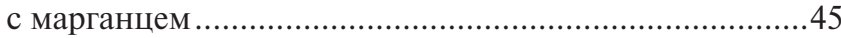

1.5.2. Термодинамика связывания мышьяка с марганцем

1.5.3. Физико-химические исследования фаз мышьяка с марганцем

1.5.4. Промышленные испытания отделения мышьяк-марганцовой пены .

1.5.5. Электромагнитное разделения расплава олова от пены 50

1.6. Фильтрация мышьяк-марганцовистой пены .53

1.6.1. Влияние марганцовистй пены на центробежную фильтрацию

1.6.2. Исследования поведения MnAs в центробежном поле 54

1.6.3. Возможности отстойно фильтрующих центрифуг .......58

1.7. Удаление остаточного мышьяка фильтрацией окисленной мышьяк-марганцевой пены

1.7.1. Ситовая характеристика и толщина пленки олова на кристаллах окисленных съемов.

1.7.2. Промышленные испытания удаления окисленной пены AsMn

1.8. Удаление меди центробежной фильтрацией совместно с остаточным марганцем .66

1.9. Промышленное освоение центробежного рафинирования олова .75

1.9.1. Принятый вариант удаления остаточного мышьяка ...75

1.9.2. Приготовление марганцевой лигатуры .......................75

1.9.3. Промышленное освоение центробежного рафинирования олова

1.10. Поведение примеси индия при центробежном рафинировании олова 80

1.11. Психологические особенности разработки и освоения новой техники 
ГЛава 2. РАФИНИРОВАНИЕ СВИНЦА ЦЕНТРОБЕЖНОЙ ФИЛЬТРАЦИЕЙ РАСПЛАВА .................................................................86

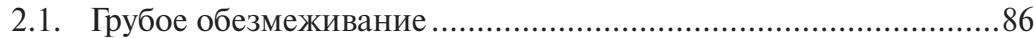

2.2. Тонкое обезмеживание ............................................................95

2.3. Центробежная фильтрация в щелочном

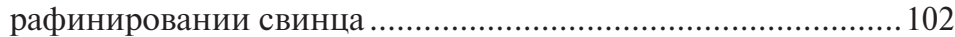

2.4. Центробежная фильтрация в обессеребрении свинца............112

2.5. Центробежная фильтрация в обезвисмучивании свинца ......112

2.6. Работы института Гидроцветмет и УКСЦК по использованию центробежных аппаратов в процессах

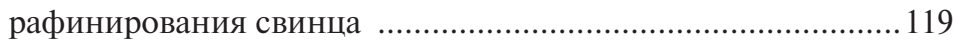

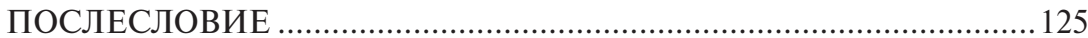

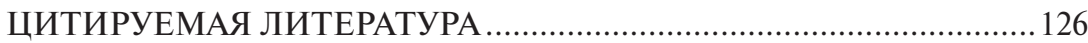

ЦИТИРОВАННАЯ ЛИТЕРАТУРА К ГЛАВЕ 2 ................................. 133 


\title{
ЦЕНТРОБЕЖНАЯ ФИЛЬТРАЦИЯ РАСПЛАВЛЕННОГО ОЛОВА И СВИНЦА
}

\author{
Монография
}

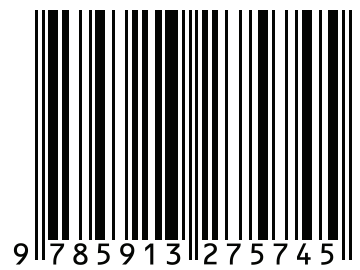

Технический редактор Кулакова Г.А.

Подписано в печать 13.03.2019

Бумага офсетная.

Гарнитура NewtonC

Формат $60 \times 841 / 16$

Печать трафаретная. Печ. л. 8,75.

Тираж 500 экз. Заказ № 007-19.

Отпечатано в типографии ИД «Академия Естествознания», 440026, г. Пенза, ул. Лермонтова, 3 